
ช 





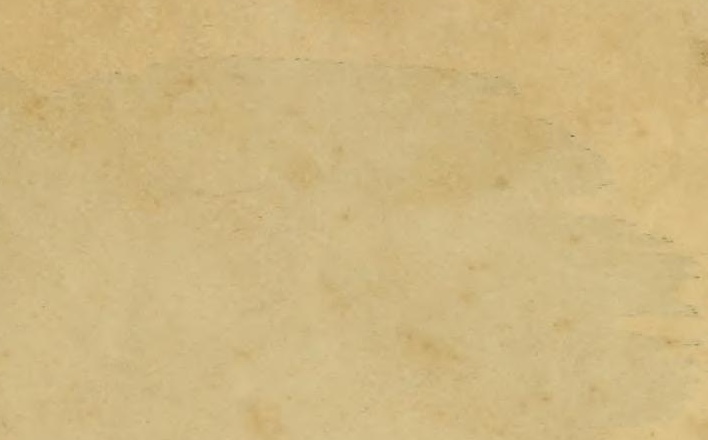

45

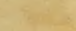

$3^{7}$ 


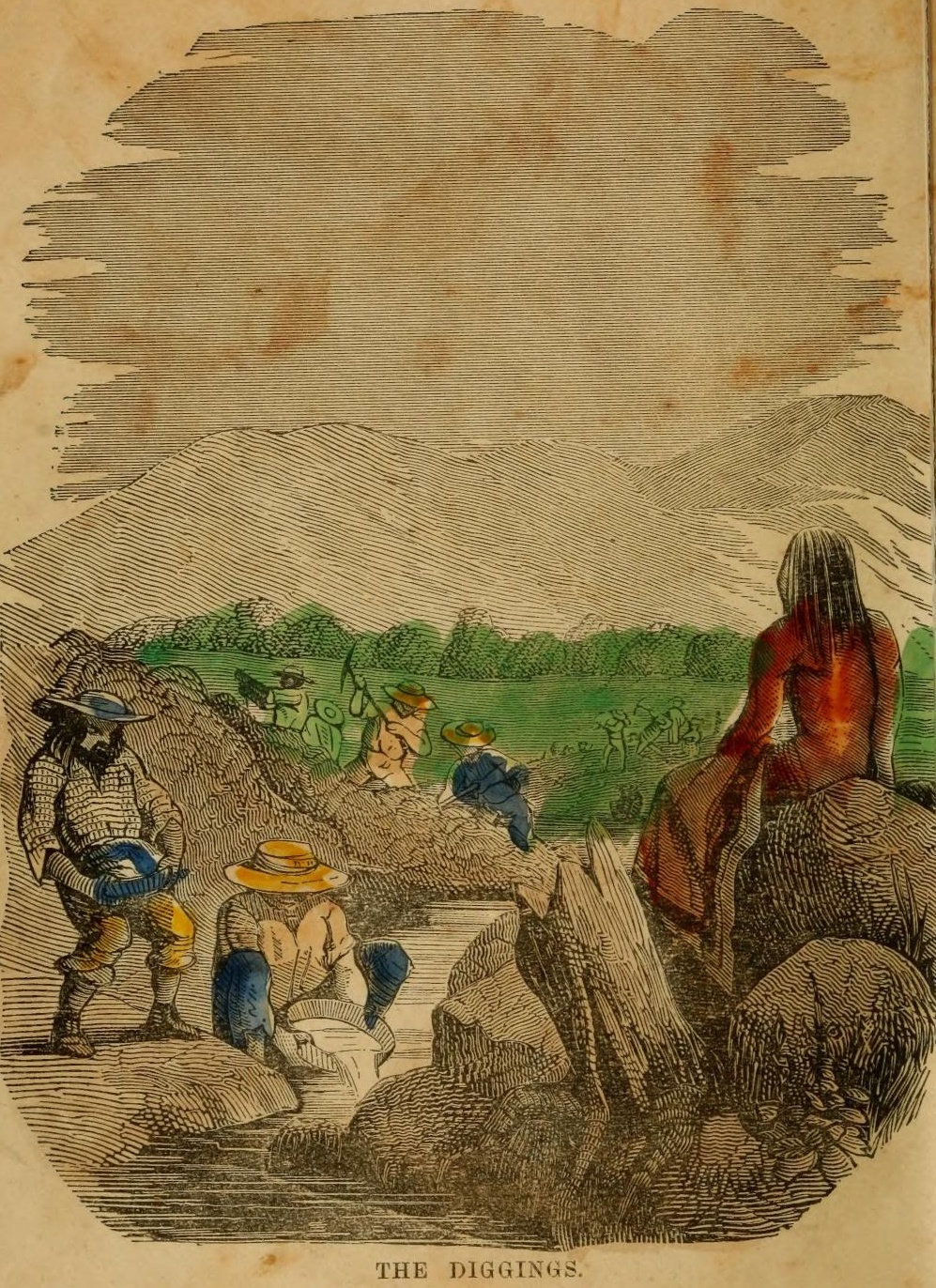




\section{FOURTH THOUSAND.}

Frost's Pictorial History of California.

\section{H I S T O R Y}

OF THE

\section{STATE \\ OF \\ CALIFORNIA.}

FROM THE PERIOD OF THE CONQUEST BY SPAIN, TO HER OCCUPATION BY THE UNITED STATES OF AMERICA.

1

CONTAINING AN ACCOUNT OF THE DISCOVERY OF THE IMMENSE

GOLD MINES AND PLACERS, THE ENORMOUS POPULATION

OF GOLD-SEEKERS, THE QUANTITY OF GOLD ALREADY OBTAINED, A DESCRIPTION OF HER MINERAL

AND AGRICULTURAL RESOURCES, WITH THRILLING ACCOUNTS OF ADVENTURES AMONG THE MINERS.

ALSO,

ADVICE TO EMIGRANTS ON THE BEST ROUTES, AND THE PREPARATIONS NECESSARY TO GET THERE.

TO WHICH IS ADDED

A BRIEF ACCOUNT OF THE FORMATION OF THE GOVERNMENT AND CONSTITUTION OF THE SAID STATE.

\section{WITH NUMEROUS ILLUSTRATIONS.}

\section{BY JOHN FROST, LL.D.}

A U B U R N, N. Y.

DERBY AND MILLER. 


\section{F865 .F935}

Entered according to Act of Congress, in the year 1850,

$$
\text { By DERBY AND MILLER, }
$$

In the Clerk's Office for the Northern District of New York.

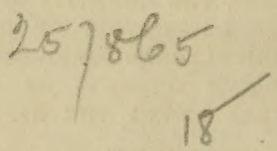

PHILADEI PHIA :

GTEREOTYPSD BY GEORGE CHARLES.

No. 9 Sansom Street. 


\section{PREF A CE.}

Tre occupation of California by the people of the United States, and the discovery of its rich gold mines, form a new era in the history of the world. According to present appearances, these events forebode a complete revolution in monetary and commercial affairs. The receipts of gold from California have already produced a sensible effect on the financial affairs of our country; and far-seeing people predict an entirely new state of things with respect to the relative value of money and property.

Still more important effects are anticipated from the establishment of a new, rich, and enterprising State of the American Union on the shores of the Pacific. Railroads across the continent will soon transport the rich products of Eastern Asia, by a quick transit, to the Atlantic cities and to Europe; and a passage to China or India, which was formerly a serious undertaking, will become a pleasant excursion. 
To gratify the public curiosity with respect to the history and present state of this new member of the Union, is the purpose of this volume. In preparing it, the author has passed rapidly over the early history, and dwelt chiefly on recent events, and the actual state of the country, as he considered that, by this course, utility would be more effectually consulted.

In the Appendix he has introduced the constitution of California, and some official documents, whose importance demanded their preservation in a permanent form. 


\section{CONTENTS}

CHAPTER I.

Page

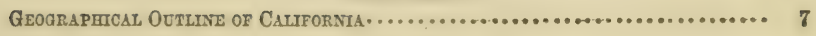

CHAPTER II.

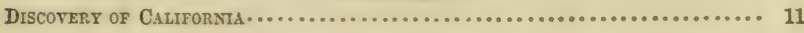

CHAPTER IIT.

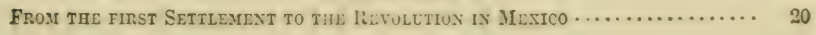

CIIAPTER IV.

Frour tae Revolution till the W.ar hetwe... the United States axd Mexico. 24

CIIAPTER v.

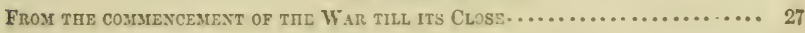

CHAPTER VI.

Discovery of the Gold Placers

\section{CHAPTER VII.}

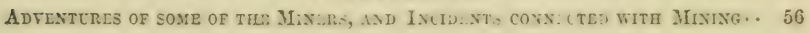

CIIAPTER VIII

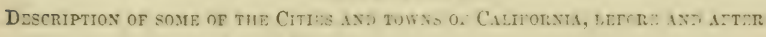

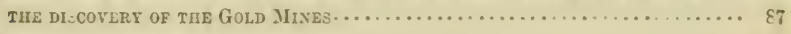

CILPTER LX.

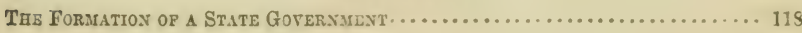

CIAPTER X.

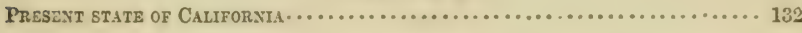

CILAPTER XI.

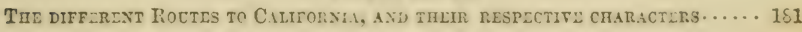

CHAPTER AII.

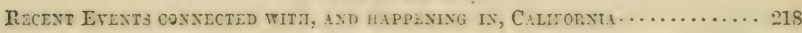

CIIAP'TER XIII.

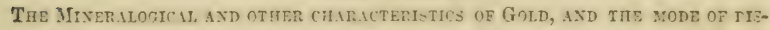
TINGUISHING IT WUEN FOUND; TOGETHLR WITI TIE ASSIX, RLDECTION, AND REFLNEMENT OF GULD 
CHAPTER XIV.

ADDITIONAL RECENT EVENTS

CHAPTER XV.

A General Viet of Cajifornia at the presext time.

CHAPTER XVI.

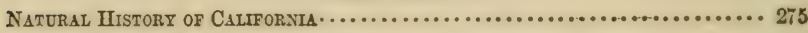

APPENDIX............................................... 387

\section{LIST OF EMBELLISHMENTS.}

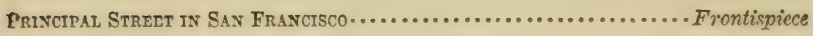

ONe of the old Spanisir Houses in San Francisco ................... 28

Ravehe in Upper California............................ 47

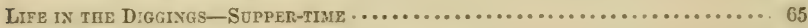

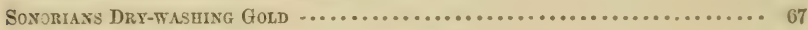

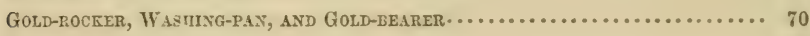

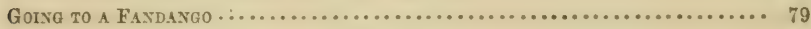

Mode of Washing Clothes in California ....................... 86

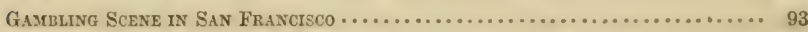

$\Lambda$ Ship's Gallex turned into a Cafe Restaurant in Say Francisco ......... 96

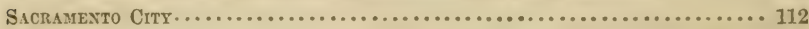

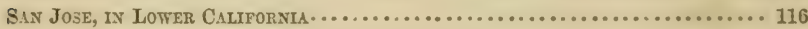

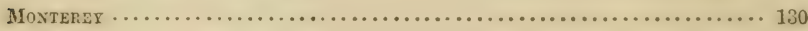

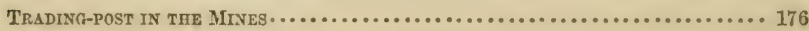

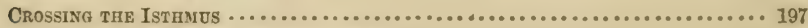

MLountain Scenert in Lower Californa ....................... 504 


\section{THE}

\section{HISTORY OF CALIFORNIA.}

\section{CHAPTER I.}

GEOGRAPHICAL OUTLINE OF CALIFORAIA.

The territory called California is that part of North America situated on the Pacific Ocean, and extending from the $42^{\circ}$ of north latitucle southwarlly to $22^{\circ} 48^{\prime}$, and from $107^{\circ}$ longitude, west from Greenwich, to $124^{\circ}$. It is bounded on the north by Oregon territory, east by territories belonging to the United States and the Gulf of California, and on the sonth and west by Mexico and the Pacific Ocean. California is raturally diviled into two portions; the peninsula, called Lower California, and the territory extending northward from the peninsula, on the Pacific Occan, called Lpper California. The line of dirision between Lpper and Lower California runs nearly along the 32 d parallel of latitude, westward from the head of the Gulf of California.

The peninsula of California is abont one hundred and thirty miles in breadth, where it joins the continent. It extends south-eastwardly, generaily diminishing in breadth, till it terminates in two points. The point farthest south-west is called Cape San 
Lucas. The other, sixty miles east by north of San Lucas, is called Cape Palmo. The peninsula is about seven hundred miles long.

Upper California extends, upon the Pacific, from the $32 d$ parallel of latitude, northrard to the $42 d$ parallel, a distance of about seren hundred miles. It is separated from Oregon by a range of highlands, called the Snowy Mountains, or, hy the Spaniards, the Sierra Nevada. The eastern limit of Upper California is rather uncertain. By some it is considered as including the region watered by the Colorado River, while others limit it by the great mountain range that extends along the western side of the continent.

The Californian peninsula seems to be a prolongation of the great restern chain of mountains. It consists entircly of high, stony ridges, separated by sandy valleys, and contains very ferr tracts of level ground. In a general view, it might be termed an irreclaimable desert. The scarcity of rain and the small number of springs of water, with the intense heat of the sun's rays, uninterrupted in their passage, render the surface of the country almost destitute of vegetation. Yet in the small oases formed by the , assage of a rivulet through a sandy defile, where irrigation is possible, the ground may be marle to produce all the fruits of tropieal climes, of the finest cuality, and in great quantity. The southern portion of the peninsula contains sereral gold mines, which iave been worked, though not to any great extent. wis the Pacific side, the coast offers many excellent 1. vobs, but the lack of wesh water near them proves an obstacle in the way of their necupation. The Fincipal harbors are the Bay of la Miagdalena, separated from the ocean by the long island of Santa 
Margarita, the Bay of Sebastian Vizcaino, east of the Isle of Cedaro, Port San Bartolome, sometimes called Turtle Bay, and Port San Quintin, a good harbor, with fresh water in the ricinity, and called by the Spanish narigators the Port of the Eleven Thousand Virgins.

The great westernmost range of mountains runs northward from the peninsula, nearly parallel with the Pacific coast, to the 3tth parallel of latitude, below which is Mount San Bernardin, one of the highest peaks in California, about forty miles from the ocean. Farther northward, the space between the mountains and the coast becomes wider, and, in a few places, reaches eighty miles. The intermediate region is traversed by lines of hills, or smaller mountains joined with the great range. The most considerable of the inferior ridges extends from Mount San Bernardin to the south sile of the entrance of the Bay of San Francisco, where it is called the San Druno Mountains. Between this rance and the coast runs the Santa Darhara range, terminating at the Cape of Pines, on the soutli-west sicle of the Bay of Monterey. Bordering on the Bay of San Francisce, on the cast side, is the Bolbona ridge. Beyond these are lines of hichlands which stretch from the great chain and telminate in capes on the Pacific.

Where are many streams among the valleys of Upper California, sme of mich, in the rainy scason, swell to a considerable size. But no river, exeept the Sacramcato, falling into the Bay of San Francisco, is known to flow through the maritime range of mountains, from the interior to the Pacific. The ralleys thus watered offer abundant pasturage for cattle.

The principal harbors of Lpper California are those 
nfiered by the Bays of San Francisco, Monterey, Ean Pedro, Santa Barbara, and San Diego. The lay of San Francisco is one of the finest harbors in the world. The combined flects of all the naval powers of Europe might there find safe shelter. It is surrounded by ranges of high hills, and joins the Pacific by a passage two miles wide and three in length. The other harbors can only be frequented in the fine season, and afford a rery insecure shelter for rescels. San Diero is the firthest snuth. The bay at that place runs ten miles castward into the land, and is separated from the ocean by a rilge of sancl. Procceding northward, about serenty miles, the Day of San Pedro is next met. It is open to the southwest winds, but sheltered from the north-west. About a hundred miles north-west of San l'elro, is the harbor of Santa Barbara. It is an mpen roadstead shelterel from the north and west winds, but cxposed to the riolence of the south-westerly storms, which prevall during the greater part of the year. A huntred miles farther north is the Bay of Monterey. It is crtensire, and lies in an indentation of the const, somewhat semicircular. The southermmost pertion is separated from the ocean by the point of lan cirling at the Cape of Pines. In the core thus formed, stands the town of Monteres, fir some time the cor ital of California. The harbor affords but a poor siclter from storms.

The Sacramento and San Joachim are the principal rirers of Califonia, but the sucramento alone is navigable to any extent worthy of mention. There are numerous small streams and lakes in the interior, the principal outet of which is the Colomelo Rirer. The vallegs through which these streams flow are 
fertile, and aford good pasture for cattle; but the remainder of the recrion between the maritime and the Colorado ranges of mountains is a barren waste of sand.

\section{CHAPTER II.}

\section{DISCOVERY OF CALIFORNIA.}

True furst exploration of the Pacific coasts of North America was made by the Spaniarls, in the sixteenth century. After IIcrnanio Cortes had completerl the conrulest of Mexico, he commeneed cxploring the adjoining seas ant countries: no doubt, with the hope of liscovering lanils richer than those which he had conquered, and which wonld afford new fields for the exercise of his daring enterprise and undaunted perseverance. He employed ressels in surveying the coasts of the Mexican Gulf, and of the Atlantic more northerly. Tessels were built upon the Pacific coast for like purposes, two of which as early as 1526 , were sent to the East Indies.

The first expedition of the Spaniards, sent along the western coast of Mexico, was conducted by Pedro Nunez de Maldonado, an officer under Cortes. He sailed from the mouth of the Zacatula Rirer, in July, 1528 , and was six months engaged in surreying the shores from his starting-place to the mouth of the Santiago River, a hundred leagues farther north-west. The territory he risited was then called Xalisco, and inhabited by fierce tribes of men who had never been 
conquerert hy the Mexicans. Flattering accounts of the fertility of the country and of the abundance of the precious metals in it were brought back by the expedition, and these served to excite the attention of the Spaniards. When the expedition returned Cortes rias in Spain, whither he had gone to have his title and powers more clearly defined. He returned in 1530 with full power to make discoreries and conquests upon the western coast of Mexico. From the opposition of his enemies, he was prerented from fitting out an expedition before 1532. The most north-

- ern post upon the Pacific coast, occupied by the Spaniards, was Aguatlan, beyond which the coast was little known.

The expedition sent by Cortes to the north-western coast of Mexico was commanded by his kinsman, Diego Hurtado de Mendoza. It sailed from Tehuantepec in July, 1532, and consisted of two ressels; one commanded by Diego Hurtado de Mendoza in person, and the other by Juan de Mazuela. Mendoza proceeded slowly along the shore of the contirent as far as the $27^{\circ}$ of latitude, where, his crew being mutinous, he sent back one of his vessels with the greater part of his men, and continued the voyage with the remaining vessel. Vague reports were afterwards received that Mendoza's vessel was thrown ashore somewhere to the northward, and that all on board had perished. The ressel which was sent back, was stranded near the mouth of the River Vanderas, and after the murder of the greater part of the crew, she was plundered. by Nuno de Guzman, Governor of Xalisco. About the middle of the next year, Cortes received the news of the return of the vessel which Mendoza had sent back, and he immediately despatched two ships under 
the command of Hernando Grijalva and Dicgo Becerra, in search of the other. These ships sailed on the 30th of September, 1533, but were soon separated. Grijalra discorcred the islands of St. Thomas, as he called them-il group of islands about fifty leagues from the coast. He remained there till the following spring, and then returned home. Becerra proceeded north-westward; but his erew mutinied, and he was murdered by Fortuno Ximenes. The mutinecrs, under Ximenes, then steered directly west from the main land, and soon reached a coast not known to them before. They landed, and soon after Ximenes and nineteen men were killed by the natives. The rest of the men carried the ressel orer to Xalisco, where she was scized by Nuno de Guz. man.

Soon after these mnlucky expeditions, Nuno de Guzman sent out sereral exploring partics in a northerly direction, one of which traced the western shore as far as the mouth of the Colorado, and brought back accounts of a rich and populous country and splendid cities in the interior. When Cortes became acquainted with the seizure of his ressels, a dispute arose between him and Nuno de Guzman, which almost led to a battle between their forces. But no action occurred, and Cortes, haring heard of the newly discorered country, which was said to abound in the finest pearls, embarked at Chiamctla, with a portion of his men, and set sail for the new land of promise. On the $3 \mathrm{~d}$ of May, $153 \bar{j}$, the day of the Invention of the Holy Cross, according to the Roman Catholic Calendar, Cortes arrived in the bay where Ximenes and his fellow-mutineers had met their fate in the previous jear. In honor of the day, the place was called 
Santa Crry, and possession of it was taken in the name of the Spanish sovereign.

The country claimed by Cortes for Spain, was the south-east portion of the peninsula, which was afterwarls called California. The bay, called by Cortes, Santa Cruz, was, perhaps, the same now known as Port La Paz, about a hundred miles from the Pacific, near the 24th parallel of latitude. Cortes landed on the shore of this bay, rocky and forbidding as it appeared, with a hundred and thirty men, and forty horses. He then sent back two of his ships to Chiametla, to bring over the rest of his troops. The ressels soon returned with a portion of the troops, and being again despatched to the Nexican coast, only one of them returned. The other was wrecked on her way. Cortes then took seventy men and embarked for Xalisco, from which he returned just in time to sare his troops from death by famine. A year was spent in these operations, and the troops began to grow discontented. A few pearls had been founil on the coast, but the country was found to be barren, and without attractions for Spaniards.

In the mean time, the wife of Cortes hearing reports of his ill success, sent a vessel to Santa Cruz, and entreater him to return. He then learned that he had been superseded in the government of New Spain by Don Antonio de Mendoza, who had already entered the capital as viceroy. Cortes returned to Mexico, and soon after, recalled the vessels and troops from Santa Cruz.

The viceroy, Mendoza, had received some information concerning the country north-west of Mexico, from de Caheza-Taca and two other Spaniards, who had wandered niue years, through forests and deserts, 
from Tampa Bay, Florida, wntil they reached Culiacan. Whey had receired from the natires, acecunts of rich and populous countries situated to the northwest. Mendoza, wishing to ascertain the truth of the reports, sent two friars, according to the advice of Las Casas, to make an exploration. They were accompanied by a Moor who had crossed the continent with Cabeza-Taca and his friends, and they set out from Culiacan on the 7 th of March, 1539.

Soon after the departure of the friar's, Cortes sent out his last expedition. It was commanded by Francisco de Ulloa, and consisted of three ressels, well equipped. Sailing from Acapulco, on the 8th of July 1539. Clloa reached the Bay of Santa Cruz, after losing one of his ressels in a sturm. From Santa Cruz he started to surrey the coast towards the northwest. He completely examined both shores of the Gulf of California, and discovered the fact of the connection of the peninsula with the main land, ncar the $32^{\circ}$ of latitude. This gulf Clloa named the Sea of Cortes. On the 18th of October, he returned to Santa Cruz, and on the 20th again sailed with the olject of exploring the coasts farther west. He rounded the point now caller Cape San Lucas, the southern extremity of California, and sailed along the coast towards the north. The Spaniards proceeded slowly, as they were opposed by north-western storms, and often landed and fought with the natives. In January, 1540, Llloa reached the island under the $2 S$ th paraliel of latitude, near the coast, which they named the Isle of Cedars. There he remained till April, when one of the ships, bearing the sick and accounts of the discoreries, was scnt back to Micxico. The rcturning ressel was seized at Santiago by the 
officers of the viccroy. The fate of the remaining vessel is uncertain. Some of the writers of that day asserting that he continued his royage as far north as the $30^{\circ}$ of latitude, and returned safely to Mexico; while one asserts that nothing more was heard of him after the return of the ressel he sen't back.

In the mean time, the two friars and the Moor penetrated a considerable distance into the interior of the continent, and sent home glowing accounts of rich and delightful countries which they said they had discovered. The inlabitants had, at first, been hostile, and had killed the Hoor; but in the end submitted to the authority of the King of Spain. Mendoza, believing the accounts of the friars to be strictly true, prepared an expedition for the conquest of the countries they described. Disputes with the different Enanish chicftains occupied some months, at the end of which Cortes returned to Spain, in disgust. Mendoza despatehed two bodics of troops, one by land, the other by sen, to reconnoitre the newly discorered land, and clear the way for conquest. The marine expedition was undertaken by two ships, under the commani of Fernando de Alareon, who sailed from Santiago on the Sth of May, 1540, and proceeding north-west along the coast, he reached the head of the California Gulf, in August of the same year. There he discovered the river now called the Colorado. The stream was ascended to the distance of eighty leagues, by Alarcon and some of his men, in boats; but all their inquiries were unsatisfactorily answered, and it was determined to return to Mexico. The ressels returned safely before the end of the year.

The land forces sent, at the same time, to the northwest, were composed of infantry and cavalry, and 
commanded by Francisco Vasquez de Coronado, who had been appointed governor of New Gallicia, in place of Nuno de Guzman. The party left Culiacan on the 22d of April, 1540, and took their way north, following the course described by thie friars. They found the route which had been represented as easy, almost impassable. They made their way over mountains, and deserts, and rivers, and, in July, they reached the country called Cibola by the natires, but found it a half cultivated region, thinly inlialited by a people destitute of the wealth and cirilization they had heon represented as possessing. What had been represented as seven great cities, were seven small towns, rudely built. A few Aurquoises and some gold and silver supposed to be good, constituted the amount of what had been termed immense quantities of jewels, goll and silver. The Spaniards took possession of the country and wanted to reinain and settle there. But Vasquez re"used to accintiessec; and after naming one of the towns he risited, Granada, he started for the north-west, in search of other comitries. The region called Cibola by the inhalitants, which Vasquez visited, is the territory now called Sonora, and is situated about the head waters of the Rivers Yanui and Gila, cast of the upper portion of the Gulf of California. The morements of the Spaniards after leaving Cibola, in August, 1540, have been the sulject of very rague and contratictory accounts. All that is certain is, that the greater part of the force soon retumed to Nexiro, and that Vasquez, with the remainder, wanlered through the interior for nearly two ycar's longer, when, leing disappointed in his expectations, he returned to Mexico in 1542.

In the spring of $15-12$, two ressels wero placed under 
the command of Juan Roderiguez Cabrillo, a Portuguese navigator of great reputation. The two vessels sailed from Navidad, a small port in Xalisco, in June, 1542. They rounded Cape San Lucas, and proceeded north-west, along the coast, as far as the 38th degree of latitude, when he was driven back, and took refuge in a harbor of one of the San Barbara islands. There Cabrillo died and the command derolved on Bartolome Ferrelo. Ferrelo was a zealous and determined man, and he resolved to procced with the expedition. He sailed towards the north, and on the 26th of February, reached a promontory near the 41st parallel of latitude, which he named Stormy Cape. On the 1 st of March, the ships reached the 44 th parallel, but they were again driren south; and the men being almost worn out, Ferrelo resolved to go back to Mexico. He arrived at Navidad on the 1tth of April, 1543. The promontory called Stormy Cape by Ferrelo, was the most northern portion of California visited by that narigator, and it is probably the same which is now called Cape Mendocino.

From all accounts that they had been able to collect, the Spaniards conclucied that neither rich and populous countries existed beneath the 40 th parallel of latitude, nor was there any navigable passage between the $\Lambda$ tlantic and Pacific Oceans to be found in the same region. They, therefore, ceased to explore the nortl-western territory for some time after the return of Ferrelo in 1543.

Having thus given a somewhat detailed account of the discovery and explorations of the territory now called California, it will be sufficient to merely mention the various expeditions that visited it prior to the first regular settlement. In the spring of 1579 , California 
was visited by Sir Francis Drake, the English navigator, who landed on the shores of a bay supposed to be that of San Francisco. He formally took possession of the country in the name of Queen Elizabeth, and called it New Albion. He left California on the 22d of July, 1579. In the spring of 1520 , Scbastian Tiscaino, under orders from the viceroy of Mexico, attempted to plant colonies on the peninsula of California, but the country was soon abandoned on account of the barrenness of the soil and the ferocity of the natives. Viscaino visited the coast of Upper California in 1602, and discorered and named some of the places Cabrillo had discorered and named long before. The Port San Miguel of Cabrillo was named Port San Diego; Cape Gralera was named Cape Conception, the name now borne by it; the Port of Pines was named Port Monterey. This was the last expedition made by the Spaniards along the coast of California for more than a hundred and sixty years.

Various attempts were made to estaislish colonics, garrisons, and fishing or trading ports, on the eastern side of the peninsula of California, during the seven. teenth century, but all failed, either from the want of funds, the sterility of the country, or the hostility of the natives. The pearl fishery in the gulf was the principal bait that attracted the Spaniards, and they succeeded in obtaining a considerable quantity, some of which were very valuable. 


\section{CHAPTER III.}

FROM THE FIRST SETTLEMENT TO THE REVOLUTION IN MEXICO.

THe first establishment of the Spaniards in California, was made by the Jesuits, in November, 1697. The settlement was called Loreto, and founded on the eastern side of the peninsula, about two hundred miles from the Pacific. On entering California, the Jesuits encountered the same obstacles which had before prevented a settlement of the country. The land was so sterile, that it scarcely yielded sustenance to the most industrious tiller, and as the settlements were all located near the sea, fishing was the resource of the settlers to make up the deficiency of food. The natives continued hostile, and killed several of the Jesuit fathers. By perseverance and kindness, the Jesuits orercame all the obstacles with which they met, and within sixty years after their entrance in to California, they had established sixteen missions, extenling along the eastern side of the peninsula, from Cape San Lucas to the head of the gulf. Each of these establishments consisted of a church, a fort, garrisoned by a few soldiers, and some stores and dwelling-houses, all under the control of the resident Jesuit fither. Each of the missions formed the centre of a district containing sereral villages of converted Indians. None of the Jesuits visited the western coast of the peninsula except on one occasion, in 1716.

Great exertions were made by the settlers to acquire 
a knowlelge of the geography, natural history and li nguages of the peninsula, and they appears to have been generally successful. The result of their researches were published in Madrid, in $175 \%$, and the work was entitled a "History of California." They surveyed the whole coast of the Gulf of California, and, in 1709, Father Kuhn, one of the Jesuit fathers, ascertained beyond doubt the connection of the peninsula with the continent, which had been denied for a century. But all the labors of the Jesuits were brought to an end in 1767. In that year, Charles III. of Spain, issued a decree, banishing members of that order from the Spanish territories; and a strong military force, under command of Don Gasper de Portola, was despatched to California, and soon put an end to the rule of the Jesuits by tearing them from their converts.

The Spanish gorernment did not intend to abandon California. The peninsula immediately became a province of Mexico, and was provided with a ciril and military government, subordinate to the viceroy of tl:at country. The mission fell under the rule of the Dominicans, and from their mode of treatment, most of the converts soon returned to their former state of barbarism. The Spaniards soon formed establishments on the western side of the peninsula. In the spring of 1769 , a number of settlers, with some soldiers and Franciscan friars, marched through the peninsula towards San Diego. They reached the bay of San Diego after a toilsome journey, and the settlement on the shore of the bay was begun in the middle of May, 1769. An attempt was made, soon after, to establish a colony at Port Monterey; but the party under Portola that went in search of the place, passed further 
on to the bay of San Francisco, and could not retrace their steps before the cold weather set in, and they then returned to San Diego. The people left at San Diego had been several times attacked by the natives, and after the return of Portola's party they almost perished for want of food. But a supply arrived on the very day upon which they had agreed to abandon the place and return to Nexico. Portola again set out for Montercy, and there effected a settlement. Parties of emigrants from Mexico came to the western shore of California during the year 1770, and establishments were made on the coast between San Diego and Monterey. The multiplication of their cattle, independent of the fruits of agricultural labor, before 1775 , made the settlers of Upper California able to resist the perils to which their situation exposed them.

In order to give efficiency to the operations on the western coast of North America, the Spanish government selected the port of San Blas, in Mexico, at the entrance of the Gulf of California, for the establishment of arsenals, ship-yards and warehouses, and made it the centre of all operations undertaken in that quarter. A marine department was created for the special purpose of advancing the interests of the Spaniards in the settlement of the western shore of California. By the energy displayed in managing this department the Spaniards succeeded in making eight establishments on the Pacific coast between the California peninsula and Cape Mendocino, before 1779. The most southern post was San Diego, and the most northern, San Francisco, on the great bay of the same name. The establishments were almost entirely. military and missionary, the object of the Spaniards being solely the occupation of the country. 
The missions were under the control of the Franciscans, who, unlike the Jesuits, took little care to exert themselves in procuring information concerning tho country in which they were established.

Various expeditions for exploring the coast of Upper Califorria above Cape Mendocino, were made by the Spaniards. One of these proceeded as far north as the latitude of 11 degrees, and some men were landed on the shores of a small bay, just beyond Cape Mendocino, and gave the harbor the name of P'ort 'Irinidad. The simall river which flows into the Pacilie near the place where they lander was called I'igeon River, from the great number of thase birks in the neighbarhood of it. The Indians appeared to be a peaccable and industrious race, and conducted themsclres towards the Spaniarls in the most inoflensive manucr. In the same year, 175j, Bodega, a Spanish commander, returning from a royage extended as far north as the 58 th degree of latitude, discovered a snall bay which had not previously been describul, and he accordingly gave it his own name, which it still retains. This Bay of Budegra is situated a little north of the 38 th degree of latitude.

Few erents worth recording occurred in California, during the whole period of fifty years, from the first establishment of the Spaniards on the western coast till the termination of the Mexican war of independence. An attempt of the Russians to form a settlement on the shores of the Bay of Bodego, in 1815, was met with a remonstrance from the gorernor of California. The remonstrance of the governor was disregarded, and his commands to quit the place disobeyed. The Russian agent, Kushof, denied the right of the Spaniards to the territory, and the governor being unable to 
enforce his commands, the intruders kept possession of the ground until 1840, when they left of their own accord.

\section{CHAPTER IV.}

FROM THE REVOLUTION TILL THE WAR BETWEEN THE UNITED STATES AND MEXICO.

BEFore the commencement of the struggle for independence in Mexico, the missions in California were, to some extent, fostered by the Spanish government, and supplies were sent to them regularly. But when the war began, the remittances were reduced, and the establishments soon began to decay. After the overthrow of the Spanish rule, in 1822, the territory of California was divided into two portions. The peninsula was then called Lower California, and the whole of the continental territory called Upper California. When the Mexicans adopted a constitution, in 1824, each of these territories became entitled to send one representative to the National Congress. At the same time, the adult Indians who could be considered civilized, were declared citizens of the republic, and had lands given to them. This, of course, freed them from submission to the missionaries, who, thus deprived of their authority, either returned to Spain or Mexico, or took refuge in other lands. The Indians being free from restraint, soon sank to a low depth of barbarism and vice.

Immediately after the overthrow of the Spanish 
authorities, the ports of Caliomia heeenn to ke the resort of forcigners, principally whalers und traders from the United States. The trar? in wlich they engaged, that of exchanging manufactured gools for the provisions, lithe and tallow furrished by the natives, was at first irregular, but as it increased, if becime more systcmatic, and mercantile houges wore established in the princinal ports. The Mexican gurernment became diswatisferl with this state of things. and ordered the gorernor of Upper California (1) Enforen the laws which prohibited foreigners from cutering or resiling in the territories of Mexico wit:out a previal pernision fom the authorities. Accomingly, in 16-8, a nunlor of Amerien citizen.s were serizel at San Diege, and liept in confincment until 189n. In that year, an insurection broke cut, headel by Goneral solis, and the captured Americans were of some assistance in suppressing it, and, in conside:ation of their serrices, they were permitted to leave the territory.

The Mexicain gorernment strore to prevent the erils expected to flow from the prescnce of numbers of toreiguers in Califonia by establishing colonies of their own citizens in the territery. A number of lus...nns were sent out from Mexico, to settle on the lants of the misions, but they nerer reached their distination. The sthinistration which originated the seheme was orerthrowil, and the new authorities o thed the settlers to le driren back to Mexico. In 1830, the fute al systen was abclished by the Merican feresnment, und a new constitution alloptec?, which destroyed all stute richts, and establisherl a contrul power. This was strumon? yessted in California. The people rose, and drore the Mexicas 
officers from the country, declaring that they would remain infepentent until the fulcral constitution was restored. The general coremment isueil strol:g yroclamations againat the Californians, and sent an expedition to re-establish its ambority. Bat General Errea, by whom the cxperlition was commanle? doclared in faror of the felcralists, and the inhabitants governed themselves until July, 3887, when they swore alieginee to the new constiution.

Things went on quietly in Califsnia unil 1812. In that year, Commolore Jones, while cruising in the Pacife, remented information which ben him to believe that Mesico lun ilechred war against the United States. He deternimed to strite a bluw at the singposed cnemy, and, accordingly, he appeared before Monterey, on the 1:th of October, 1842, with the frigate United Btaks and the Elonp-of-war Cyane. He demanderl the surrender of all the castles, fusts, and military places, on pemity, if refused, of the vilitation of the horrors of war. The perple were astonished. A comcil decided that no defence could be mude, and exery thing was surrenterul at once to the unexpected Ammieans. The llag of the Tnited Stateg was hoisterl, am the cummodore issued a proclamation to the Californians, inviting them to submit to the government of the Cnitud States, which woul.l frotect them in the excreise of their richts. The proclamation was scarecly issucd, before the commodure becane aware of the peaceahle relutions existing between the United States and Mexico, and he accordingly restored the possession of Monterey to the authorities, and retired with his forces to his ships, just twenty-four hours after the surrender. This affair irritat d the inhabitants considerably, and, no 
doubt, tended to increase tlic ill-feeling before cxisting between Mexico and the people of the Linited States.

\section{CHAPTER V.}

FROM THE COMMEXCEMEXT OF THE WAR TILL ITS CLOSE.

War was declared by Mexico against the United States, in May, 1846. The same month, orders were transmitted to Commodore Sloat, commanding the Pacific squadron, instructing him to protect the interests of the citizens of the Tnited States near his station, and to cmploy his forces to the best adrantage in operations dirceted against the Mexican territory on the Pacifie. The fect uniler Commolore Sloat was the largest the Americans ever sent to that quarter; and the men were anxious to commence active operations. Soon after receiving his first orders, the commorlore was again instructed to take and keep possession of Cpyer California ; or, at least, of the principal ports.

On the Sth of June, Commodore Sloat left M!azatlan, in the flag-ship Sarannah, and on the $2 d$ of July, reached Monterey, in $\mathrm{C}_{\text {pper }}$ California. There he found the Cyane and Levant, and learned that the Portsmouth was at San Francisco, as previously arranged. On the morning of the 7th, Captain Mervine was sent to demand the surrender of Monterey. The Mexican commandant replied that he was not authorized to surrender the place, but referred Com- 
modore Sloat to the commanding-general of California. A force of two hundred and fifty marines and seamen was immediately landed, under Captain Nervine, and they marched to the custom-house. There they hoisterl the American flag amil cheers and a salute of twenty-one guns. The proclumation of Conmolore Sloat was then read and posted about the town.

After taking possession of Monterey, Commodore Sloat despatched a courier to the commanding-general of California, summoning him to surrender every thing under his control in the country, and assuring him of protection if he should eomply. The general refused, and said he would defend the country as long as he could reckon on a single person to join his cause. A summons to surrender was also sent to the gorernor of Santa Barbara, but no answer was returned. Orders were despatched to Commander Montgomery, in the Portsmouth, at San Francisco, directing him to take possession of the Bay of San Francisco, and hoist the flag of the United States at Yerba Buena.

On the 9th of July, the day after the receipt of his orders, Montgomery landed at Ierba Buena with seventy seamen and marines, and hoisted the American flag in the public square, anilil the checrs of the people. A proclamation was then posted to the flag staff, and Montgomery addressed the people. The greater part of the seamen and marines then returned to the ship, leaving Lieutenant II. B. Watson with a small guard, formally installed as military occupant of the post. Thirty-two of the male residents of Yerba Buena were enrolled as a rolunteer corps, choosing their own officers. Lieutenant Missroon was de:spatched with a small party of these volunteers to reconnoitre the Presidio and fort. He returned the 

same dar, and reported that the Presidio had becrt abandoned, and that the fort, seren miles from the torn, was dilapilated and mounterl only a fow old pieces of cammon. Iflu llag of the United States had been displayed foum its ramparts. On the 11th, Montgonery infurmen Cummonlme Sloat that the fleg of the Cintud States wh then flying at Yorba Buens, Sutter's Fort, on the Sucramento, Bodega, on the coast, and Sonoma. The inliabitants of these places appeared to be satkfed with the protection aflorded them by the Americans.

On the 13th of July, Commodoro Siont sent a flag to the foreicners of the pueblo of San Jore, about serenty miles from Monterey, in the interino, ant appointer a justice of the prace in plues of the alemhles. On the 15th, Conmoilore Btocktm amiven st Mlonterey, in the frigate Congress; ant Commodore Sloot heing in bat health, the cmamand dewolved upon Sruckion, and Stuat retumed home. The operations of Commolore Stockton, from the 281 af Juty to tho 28th of Aucust, 1846. Inve ben rapitly alceteled by himelf in lis ciespatches to the secretary of the nery. From these we condense a short account.

On the 23id of July, the commodors ofenized the "California Battalion of Mounted llilmmen." Captain Fromont was appointed magor, and Jieutonant Oit. lespio captain of the battalion. The next deg they were embarkel on board the slownef-wap Cyane, Commandor Dupont, and sniled from Nonterey for Sin Dirgo, in order to hind south of the Mexionn foree, consinting of 500 men, unter Conenl Castro, well fortifen at a phee three miles frnm t'ie city. A few days afierwark, Commolore Stockion salled in the Congress for Sun Pedro, thirty miles from Monte- 
rey, and having landed, marched for the Mexican camp. When lie arrived rithin twelve miles of the Milexicans, they fled in smoll partics, in different directions. Miost of tie prineipul offeces were afterwurds talkon, but the mountel rillemen not getting up in time, most of the min cecapert. On the $18 \mathrm{~h}$ of August, Commulore Stockton leme joincil by kighty riflemen, unlux Major Frement, cutered the cantal of Califurnia, Cuidad de los Angeles, or the "City of the Angels." Thus, in less than a month after Stockton's assuming command, the American flig was flying from every commanding position in Califo: nia, conquered by three hundred and sixty men, mostly sailors.

The form of government established in California, after the conquest, was as fullows: The executive power was rested in a governor, holling office for four years unless sooner remored by the Presilent of the Inited States. The gorernor was to reside in the territory, be commander-in-chief of the army thereof, perform all the duties of a superintendent of Indian affiars, have a pardoning and reprieving power, ccmmision all persons appointed to office muler the laws of said territory, and approre all laws passed by the legislature before they took cfict. Where was the ofice of the Secretary of the Territory establislicd, whose principal duty was to prescrve all the laws arid proceedings of the legislatire comcil, and all the ato anl proceclings of the goremo. The lowistate jowcr was rested in the governor and a council of

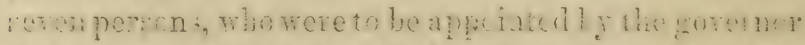

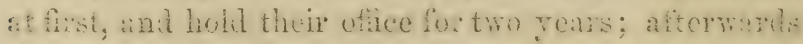
Wey wore to be elected by the poule. All he liaws cf Mexico, and the municipal cureers existing in the 
torritory hefore the enfuest, were continuch vnth altered by the governor and council.

On the Leth of Aurgut, 1ath, Commotho Siocltom adopterl a tarif of dution on all gomils imported form

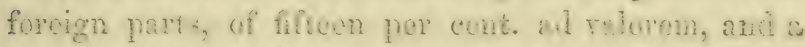
tonmege dury of fifly erents por ton on all loreien vessols. On the 7, th of Suptenibor, when the cleotions

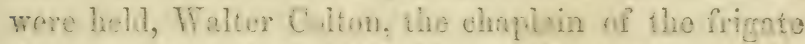
Congress, was clecterl Aleaile of Minterey. In the

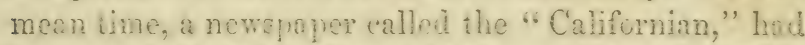
been establisued by Mesara. Colion and Semple. This Fas the first newspaper iesued in California.

Larly in Septomber, Commotore Siockton withdretr his forces from Los Angeles, and procccted with his squadron to San Francisco. Scercely hal ho amirol when he received intelligence that all the country bolow Monteroy was in arms and the Moxican fhe again hoistcl. The Califormians investel the "City of the Angols." on the 284 of September. That place was guardod by dirty ritemen under Captain Gillrspio, and tho Califomiuns inresting is numbered 300. I'maing himelf ovorpowered, Cuptain Gilhoppio capituleted on the $30 t \mathrm{~b}$, and thonce rotined with all the forticners about of a sloop-of-war, and salled fon. Montorng. Wieut nant Tallot, who commanded only

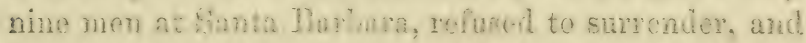
machor out wilh lis men, arme in hond. The frigate

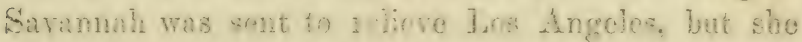
dirl not amive till afiar the ahure events ind ocenred. Her crow, numbering s.0 men, Innled at Ban Pedro and morked to mont the Calihmians. Ahout hall way boween Sun Perlow and Los Anpelos, about fiften wiles from the H Hiph, the suilons found tho enemy drawn un on s plais. The Californians moro 
mounted on fine howses, and with artillery, had crery arlwatage. The sailors were foreed to retreat with a loss of five killed and six wounded.

Commodore Stockton came luwn in the Congress to San ledro, and then marched for the "City of the Angels," the men dragging sir of the ship's guns. At the Rancho Sepulvida, a large force of the Californians was posted. Commodore Stockton sent one hundred men forward to receire the fire of the enemy and then fall back unon the main borly withont returning it. The main body was formed in a triangle, with the guns liid by the men. Iy the retreat of the advanee party, the encmy were decoyed close to the main force, when the wings wore.cxtenterl and a deadly fire opened upon the astonished Californians. More than a hundred wore killed, the same number wounded, and their whole force routed. Aljout a limmed prisoners wice taken, many of whom were at the time on parole and had signed an obligation not to take up arms during the war.

Commodore Stockton soon mounted his men and prepared for operations on shore. Skirmishes followed, and were continually occurring until January, 1847, when a decisire action oceurred. General Kearny had arrived in Califurnia, after a long and painfal march orerland, and his co-operation was of great service to Stockton. The Ameriens left San Diero on the 22th of Decemler, to march to Los Anciles. The Californians detemined to meet them on therr

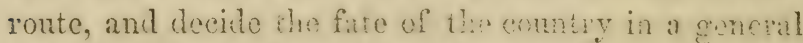

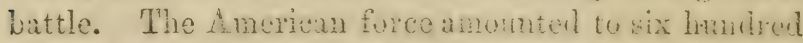
men, and was composel of detuchants fecm the ships Congress, Sarannah, Pontsmounh and Cyans, aiced by General Kearny, with sixty men on foot, from the 


\section{HISTORT OF OALIFCRNIA.}

first repiment of United States draceoons, anc? Cay tain Cillespie with sisty manted rillement. 'i he truts

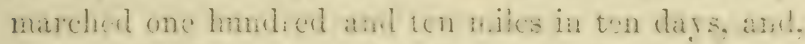
on the sth of January, the foum the Califomians in a strone fosition on the hiph hank of the san Gabia] ri er, whin six hunted unsunted men and four pieces of arillery, prepared to rispute the passage of the river. The Amerienas walded throngh the water, dragering their guns with them, expused to a galling fire from the comy, withent returning a shot. When they reached the opposite shore, the Californians charged upon them, but were drircn back. Tley tl en charged up the lante and suceceled in driving the Califomians fom their jost. Stockton, with his f) en, continue lhis mareh, and the next dar, in crossing the plains of Mesn, the encmy mate anotler attrmet to sare their capital. They were concealed with theip artillery in a ravine, until the Americans came within gran-hot, when they openert a briks fire upon their right flank, and at the same time charged lowh theix front and ycar. Sht the suns of the Californians were som silement, and the charce repelled. The Caliemians then fled, and the next morning the Americans enterer Ios Angeles without opposition. The loss of the Anericuns in libllerl and wounded did not exceed twenty, while that of them opponents reached between seventy and eighty.

These two battles deciled the contest in California. General Flores, gorernor and commandant-general of the Californians, as he styled himself, immediately after the Americans enterert Los Angeles, made his escape and his tronpls dispersert. The territory became again tranguil, and the civil gorernment was soon in operation again in the places where it had 
been interrupted by the rerolt. Commodore Stockton and General Kearny haring a misunderstanding about their respective powers, Colonel Fremont exercised the duties of governor and commander-inchief of California, declining to obey the orders of General Kearny.

The account of the adrentures and skirmishes with which the small force of United States troops under General Kearny met, while on their march to San Diego, in Upper California, is one of the most interesting to which the contcet gave birth. The party, which consisted of one humbed men when it started from Santa Fé, reached Warner's rancho, the frontier settlement in California, on the Sonoma route, (n) the $2 \mathrm{~d}$ of December, 184t. They continued their march, and on the 5th were met by a small party of volunteers, under Captain Gillespie, sent out by Commodore Stockton to meet them, and inform them of the revolt of the Californians. The party encamred for the night at Stokes's rancho, al out forty miles from San Diego. Information was received that an armed party of Californians was at San Pasqual, three leagues from Stokes's rancho. A party of drargoons was sent out to recomnoitre, and they returned by two o'clock on the morning of the 6th. Their information determined General Kearny to attack the Califomnians before daylight, and arrangements were accordingly marle. Captain Jolnson was giren the command of an adrance party of twelve dragroons, mounted upon the best horses in possession of the party. Then followed fifty dracoons, under Cantain Ifore, mounted mostly on the tired mules they had ridlen fiom Santa Fé-a distance of 1050 miles. Next came about twenty volunteers, under 
Captain Gibson. Then followed two mountain howitzers, with dracgoons to mange thenn, muler charge of Lieutenant Davilson. The remainlur of the dragoons and roltintecrs were placed tinler commund of Dajor Sirords, with arders to follow on the trail with the bagrage.

As the dey of December bih dawnd. the enemy at Bun Purgual wereseen to be alrouly in the saldle, and Captain Johnson, with lis alrance guard, made a furious charge upon them; he being sulporten by the dragoons, the Californians at leigth guve way. They had kept up a continut lim fom the first appearance of the dhageons, an! hat done consinderable cxecution. Captain Johuson was shot deat in his first charge. The enemy were pursued by Cuptain Moore and his dragoons, ant they retreated about half a mile, whon secing an interval betwren the small advanoe party of Captain Moore and the main fores coming to his support, they rablicul their whole foroe, and charecel with their lances. For five minutes iley held the gromul, doing emsintenble excution, until the arrisal of the rest of the Anerican party, when they broke and fled. The troops of Keamy lost two captains, a lieutenant, two sergeants, two corpmols, and twelse privates. Amnng the womblal were General Kearny, Lieutenunt Warner, Captains Gillespie and Gilsom, one sergeant, one hugleman, and nime privates. The Californians carricil off all their wounded and dead except six.

On the the the march was resumed, ant, near San Bernarlo, Fearny's allrance encountered and defeated a small party of the Callfornians who had taken post on a hill. It san Bernardo, the troope remanem till the morning of the 11th, when they frere juined by a 
party of sailors and marines, under Lientenant Gray. They then proceeted mon their march, and on the 12th, arrived at San Diego ; having thus completed a mach of eleren humled miles through an encny's econtry, with but one hun reil men. The fore. of Coneral Kemmy having joined that of Commotore Stivekton, the expedition against Los Angeles, of which we have given an acemmt in this chapter, was successfully consummated, and tranruillity restored in California. General Kearny and Commorlore Storkton retumed to the United States in January, 1847, learing Colonel Fremont to exereise the ofice of governor and military commandant of California. No further erents of an importance worth recording oceurred till the treaty of peace between the United States and Mexico.

\section{CHAPTER VI.}

\section{DISCOVERY OF THE GOLD PLACERS.}

Br the treaty concluded between the United States and Mexico, in 1847 , the territory of Upper California became the property of the United States. Little thought the Mexican gorernment of the value of the land they were cerling, further than its commercial importance; and, doubtless, little thought the buyers of the territory, that its soil was pregnant with a wealth untold, and that its rivers flowed orer golden beds.

This territory, now belonging to the American 
Union, cmbraces an area of 448.961 spmare miles. It

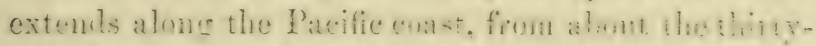
second parallel of north Intitule, a disturee of arat ecren humdred miles, to the fory-secosin pamald, the sonthern bountary of Oregon. On the cast, it is bounded by New Mexico. During the long periud which transpired between its disenrery and its ecesion to the Cuited States, this rast tract of country was frequently visited by men of science, from all parts of the world. Repeated examinations were marle by learned and cnterprising offecrs and civilians; but none of them discovered the important fact, that the mountain torrents of the Sierra Nevarla were constintly pouring lown their golden sands into the valleys of the Sacramento and San Joaruin. The glittering particles twinkled bencath their fect, in the ravines which they explored, or glistened in the watercourses which they foriterl, yet they passed them by miliecled. Frot a legend or tradition was heard among the white scttlers, or the aborigines, that attracted their curiosity. A nation's ransom lay within their grasp, hut, strange to say, it cseaped their notice-it fiathed and sparklerl all in vain.*

The lunkian Ancrican Company har a large estat) lishment at Ross and Borlega, nincty miles no;th of Sun Francisco, founded in the year 1812; and fuctories were also established in the territory by the Ilurkon Bay Company. Their agents and empilnies ransacked the whole country west of the Sienra Nevala, or Snowy Monntain, in scarch of game. In 18:3, Cantuin Sutter, formerly an oficer in the Swiss

* A gold plarera was discovered sume years ago, near the mission of San Fermando, but it was very little worked, on account of the want of water. 
Guards of Charles X., King of France, emigrated from the state of Missouri to Upper California, and obtained from the Rexican gorernment a conditional grant of thirty leagucs square of land, bounded on the west by the Sacramento river. Having purchasel the stock, arms, and ammunition of the Iuscian establishmont, he erceted a dwelling and fortifeation on the left bank of the Sacramento, about fifty miles from its mouth, and neur what was termel, in allusion to the new scttlers, the American Fort. This formed the nucleus of a thriving settlement. to which Captain Sutter gave the name of New Helvetia. It is situated at the heal of navigation for ressels on the Sacmemento, in latitude $38^{\circ} 33^{\prime} 45^{\prime \prime}$ north, and longitude $121^{\circ} 20^{\prime} 05^{\prime \prime}$ west. Iung a resilence of ten years in the immediate ricinity of the recently discovered. placeras, or gold regions, Captain Sutter was neither the wisor nor the richer for the brilliant treasures that lay scattered around him.*

In the year 1811, careful examinations of the Bay of San Prancisco, and of the Sacramento River and its tributarice, were made by Lientenant Wilkes, the commander of the Exploring Expecition; and a party uniler Lieutonant Linmons, of the nary, proceeled up the valley of the Willamette, crosscd the interrening highlands, and descended the Sacramento. In 1813-4, similar examinations were made by Captain, afterwards Lieutenant-Colonel Fremont, of the Topographical Enginecrs, and in $18 \frac{1}{4} 6$, by Major Emory, of the same corps. Fone of these officers made any discoveries of minerals, although they were led to conjecture, as private indiriduals who had risited the

* Farnham's Adventures in California.-Willes's Narrative of the Exploring Expedition.-Fremont's Narrative. 
country had done, from its rolcanic formation and peculiar geological features, thint they night be found to exist in considerable quantities.*

As is often the case, chonce at Jongth accomplished what science hat frited to de. In the winter of

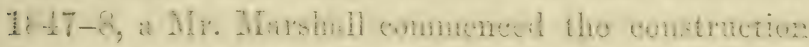

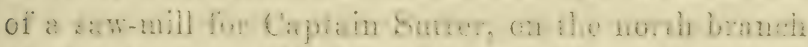
of the Aucian fork, and abont fity miles aboje New Ilelretia, in a region al oanting wh h pine timler. The dam and race were completerl, but on attempting to pat the mill in motion, is was ascertainctl that the tail-race was ton namew to permit the water to cacape with berfect freetem. A strong current was then passed in, to wath it wider and decper, ly which a large loul of mul amd grarel was thrown up at the

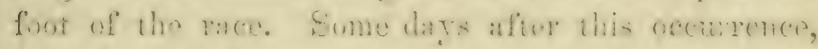

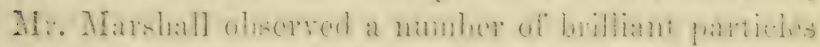

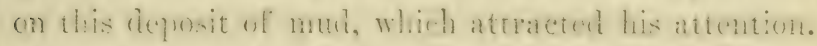
On cxamining them, he became satidfed that they were gold, and commonicated the fact to Captan Surter. It was agreed letween them, that the circumstance stould not he mate priblic for the present; Wut, like the secret of Minlas, it combl not be enencealcrl. The Normon enigrants, of whom Mr. Marslabll was one, were soon male acquainted wilh the disorery, and in a few wecks all California was agitated wib the starling information.

* See Faruham's Adrentries. Willes's and Fremont's Nariatives, and Emory's Report.- In 184 , Eugenio MIacnamara, a Catlulic priest and Missionary, ohrained a grant of a lasge trace of land beiwren the

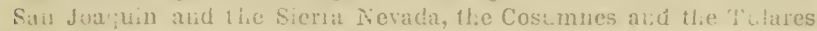
in the ricuity of San Gabricl, liom Pio Pico, governor of the Cititiornias, for tie purpose ol establishing upon it a large colony of lish Catholics; but the grant was not ratified by the Cential Govenment, and the project was not carried into effect. There is no evidence that Father Macnanara was aware of the existence ol guld in ihe valley of the San Joaquin. 
Business of every kind was nerlected, and the ripened grain was left in the fields mulnarvesterl. Nearly the whole population of Tpper Califurnia became infected with the mania, and flocked to the mines. Whalers and merchant ressels entering the ports were abandoned by their erews, and the American soldiers and sailors deserted in scores. Upon the disbandment of Colonel Stevenson's regiment, most of the men made their way to the mineral regions. Within three months after the discovery, it was comIuted that there were near four thousand persons, including Indians, who were mostly employed by the whites, engaged in washing for gold. Various morles were adopted to separate the metal from the sand and cravel-some making use of tin pans, others of closer.oren Indian baskets, and others still, of a rude machine called the cradle, six or cight feet long, and mounted on rockers, with a coarse grate, or sieve, at cne end, but open at the other. The washings were nainly confined to the low wet grounds, and the markins of the streams-the carth being rarcly clisturbed more than eightee inches below the surface. The value of the gold dust obtainch by each man, per day, is said to have ranged from ten to fifty dollars, anil sonctimes even to have far exceerled that. The natural consequence of this state of things was, that the firice of labor, and, inteed, of every thing, rose inimecliately from ten to twenty fold.*

As may readily be conjectured, every stream and ravine in the valley of the Sacramento was soon cxplored. Gold was found on every one of its tributa-

* Official Despatch of Colonel Mason, Commander of the 10th Military Departinent, August 17, 1848.-Letiors of Thomas C. Larhin, U. S. Consul at Monterey, to the Secretary of State, Juno 1, and June $28,1848$. 
ries; but the wirhut earth was discorered near the Iicu de los Plumas, or Feather River, " and its branche's, the Yuba and Bear rivers, and on Weber's creck, a tributary of the Americun Fork. Explonations were aloo made in the valley of the Sun Joaruin, which resulted in the discorery of cold on the Cosumnes and other streams, and in the rarines of the Coast Range, west of the valley, as far down as Ciudad de los Angeles.

In addition to the gold mincs, other important discoveries were made in Epper Califormia. A rich rein of quicksilver was opened at New Almalen, near Sunta Clara, which, with imperfect machinery, - the heat by which the metal is male to exule from the rock being applied by a very rule process,- - yielded orer thirty per cent. This mine-one of the principal adrantages to be derived from which will be, that the working of the silver mines scattered through the territory mast now become profitable-is superior to those of Almalen, in Gld Spain, and second only to those of Ichia, near Trieste, the richest in the world.

Learl mines were likewise discovered in the neighborhood of Sonoma, and rast beds of iron ore near the American Fork, yielding from eighty-five to nincty per cent. Copper, platina, tim, sulphur, zinc, and cobalt, wore discorered every where; coal was found to exist in large quantitics in the Cascale range of Oregron, of which the Sierra Nevada is a continuation; and in the ricinity of all this mineral wealth, there

* Featleer River is the first considora'ble hranch of the Sacramento below the Prutrie Bulles. It hes a cuuree of about hrty males. and

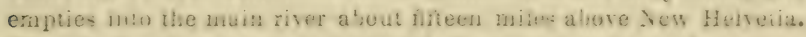
Though the Sacramenio is navigable for vessels oniy to that filuce, boats can pass up one hundred miles further. 
are immense quarries of marble and granite, for building purposes.

Colund Mirson har succecded Colonel Fremont in the pust of governor of Califomia and military commankint. A regiment of Few Ionk troops, meler the emmmnd of Colonel Sterenson, hat been ordered tu Califoria before the conclusion of the treaty of peace, and formed the principal part of the military force in the territory.

Colonel Mason expressed the opinion, in his official despatch, that "there is more gold in the conntry drained by the Sacramento and San Joaquin rivers, than will pay the cost of the [late] war with Mexico a liundred times over." Should this eren prove to be an exaggeration, there can be little reason to doubt, when we take into consideration all the mineral resources of the country, that the territory of Califoruia is by far the richest acquisition made by this government since its organization.

The appearance of the mines, at the perior of Gorernor Mason's risit, three months after the discovery, he thus graphically describes:

"At the urgent solicitation of many gentlemen, I delayed there [at Sutter's Fort] to participate in the first public celebration of our national anniversary at that fort, but on the 5th resumel the journey, and proce deal twenty-five miles up the American Fork to a point on it now known as the Lower Mines, or Mormon Wigmins. The hill-siles were thickly strewn with cainsas tents and bush arbors; a store was erected, and sweral loarling shanties in operation. The day was intensely hot, yet about two huudren men were at work in the full glare of the sun, washing for gold -some with tin pans, some with close-roven Indian 
baskcts, but the greater part hal a rule machine, known as the cradle. This is on rockers, six or eightit feet long, open at the foot, and at its heed has a coarse grate, or siere; the lottom is ruunded, with small cleats nailcd across. Four men are recuired to woik this machine; one digs the ground in the bank close by the stream; another carries it ts the cradle and empties it on the grate; a third gires a riolent rocking motion to the machine; while a fourth dashes on water from the stream itself.

"The sieve keeps the coarse stones from entering the cradle, the current of water washes off the carthy matter, and the gravel is gradually carried ont at the foot of the machine, learing the gold mixed with a heary, fine black sand abore the first cleats. The sand and gold, mixed togrether, are then drawn of through auger holes into a pan below, are drick in the sun, and afterward separatel by blowing off the sand. A party of four men thus cmployed at the lower mines, areraged $\$ 100$ a day. The Indians, and those who have nothing but pans or willow baskets, grachally wash out the earth and separate the grarel by hand, learing notling but the gold mixed with sand, which is separated in the manner before described. The gold in the lower mines is in fine bright scales, of which I send several specimens.

"From the mill [where the gold was first discovered], Mr. Marshall guided me up the mountain on the opposite or north bank of the south fork, where, in the bed of small streams or rarines, now dry, a great deal of coarse gold has been found. I there saw several parties at work, all of whom were doing very well; a great many specimens were shown me, some as heary as four or fire ounces in weight, and I send 
three pieces, labeled No. 5 , presented by a Mr. Spence. You will perceive that some of the specimens accompanying this, hold mechanically pieces of quartz; that the surface is rough, and evidently moulded in the crevice of a rock. This gold cannot have been carried far by water, but must have remained near where it was first deposited from the rock that once bound it. I inquired of many people if they had encountered the metal in its matrix, but in every instance they said they had not; but that the gold was invariably mixed with washed gravel, or lodged in the erevices of other rocks. All bore testimony that they had found gold in greater or less quantities in the numerous small gullies or ravines that occur in that mountainous region.

"On the 7th of July I left the mill, and crossed to a stream emptying into the American Fork, three or four miles below the saw-mill. I struck this stream (now known as Weber's creek) at the washings of Sunol and Co. They had about thirty Indians employed, whom they payed in merchandise. They were getting gold of a character similar to that found in the main fork, and doubtless in sufficient quantities to satisfy them. I send you a small specimen, presented by this company, of their gold. From this point, we proceeiled up the stream about eight miles, where we found a great many people and Indians-some engaged in the bed of the stream, and others in the small side valleys that put into it. These latter are exceedingly rich, and two ounces were considered an ordinary yield for a day's work. A small gutter not more than a hundred yards long, by four feet wide and two or three feet deep, was pointed out to me as the one where two men-William Daly and Parry McCoon-had, a short 
time befure, olstained $\$ 17,000$ worth of gold. Captain Weber informed me that he kncw that these two men lial employed four white men and about a humbed Indians, and that, at the end of one weck's work, they paid off their parts, and had left 810,000 worth of this colle. Another small ravine was shown me, from which hand bean taken upwaxd of $\$ 12,000$ worth of gold. Hondreds of similar ravines, to all appearances, are as yet untunched. I could not have credited these repiorts, hall not seen, in the alundarce of the precious metal, evidence of their truth.

"Mr. Neligh, an agent of Commolore Stockton, had been at work about three weeks in the neighlorhood, and showed me, in lag ges and botiles, orer $\$ 2000$ worth of gold; and Mr. Lyman, a gentleman of education, and worthy of every credit, said he had been engagel, with four others, with a machine, on the Ancrican Fork, just below Suter s mill; that they worked eight days, and that his share was at the rate of fify lollars a day; but hearing that others were dnirg better at Weber: s place, they hud renoved there, anil we: e then on the point of resuming operations. I might tell of hundrerls of similar instances; but, to illustrate how plentiful the gold was in the pockets of common laborers, I will mention a single occurrence which took place in my presence when I was at Theber's store. This store was nothing but an arbor of bushics, uniler which he had exposed for sale goods and grocerics suited to his customers. A man came in, picked up a box of Seidlitz powders, and asked the price. Captain líeber told him it was not for sale. The man offered an ounce of gold, but Captain Weher told him it only cost fifty cents, and he did not wish to sell it. The man then offered an ounce and a half, 
when Captain Weber had to take it. The prices of all things are kigh, and yet Indians, who before hardly knew what a breech cloth was, can now afiord to buy the most gaudy dresses.

"The country on cither side of Weber's creck is much broken up by hills, and is intcrsected in every direction by small streams or ravines, which contain more or less gold. Those that have been worked are barely scratched; and although thousands of ounces have been carried away, I do not consider that a serious impression has been made upon the whole. Every day was developing new and richer deposits; and the only impression seemed to be, that the metal would be found in such abundance as seriously to depreciate in value.

"On the 8th of July, I returned to the lower mines, and on the following day to Sutter's, where, on the 19th, I was making preparations for a visit to the Feather, Yuba, and Bear Rivers, when I received a letter from Commander A. R. Long, United States Navy, who had just arrived at San Francisco from Mazatlan with a crew for the sloop-of-war Warren, with orders to take that ressel to the squadron at La Paz. Captain Long wrote to me that the Mexican Congress had adjourned without ratifying the treaty of peace, that he had letters from Commodore Jones, and that his orders were to sail with the Warren on or before the 20th of July. In conscquence of these, I determined to return to Mlonte"ey, and accorlingly arrived here on the 17th of July. Before leaving Sutter's, I satisfied myself that gold existed in the bed of the Feather River, in the Yuba and Bear, and in many of the smaller streams that lie between the latter and the American Fork; also, that it had been 



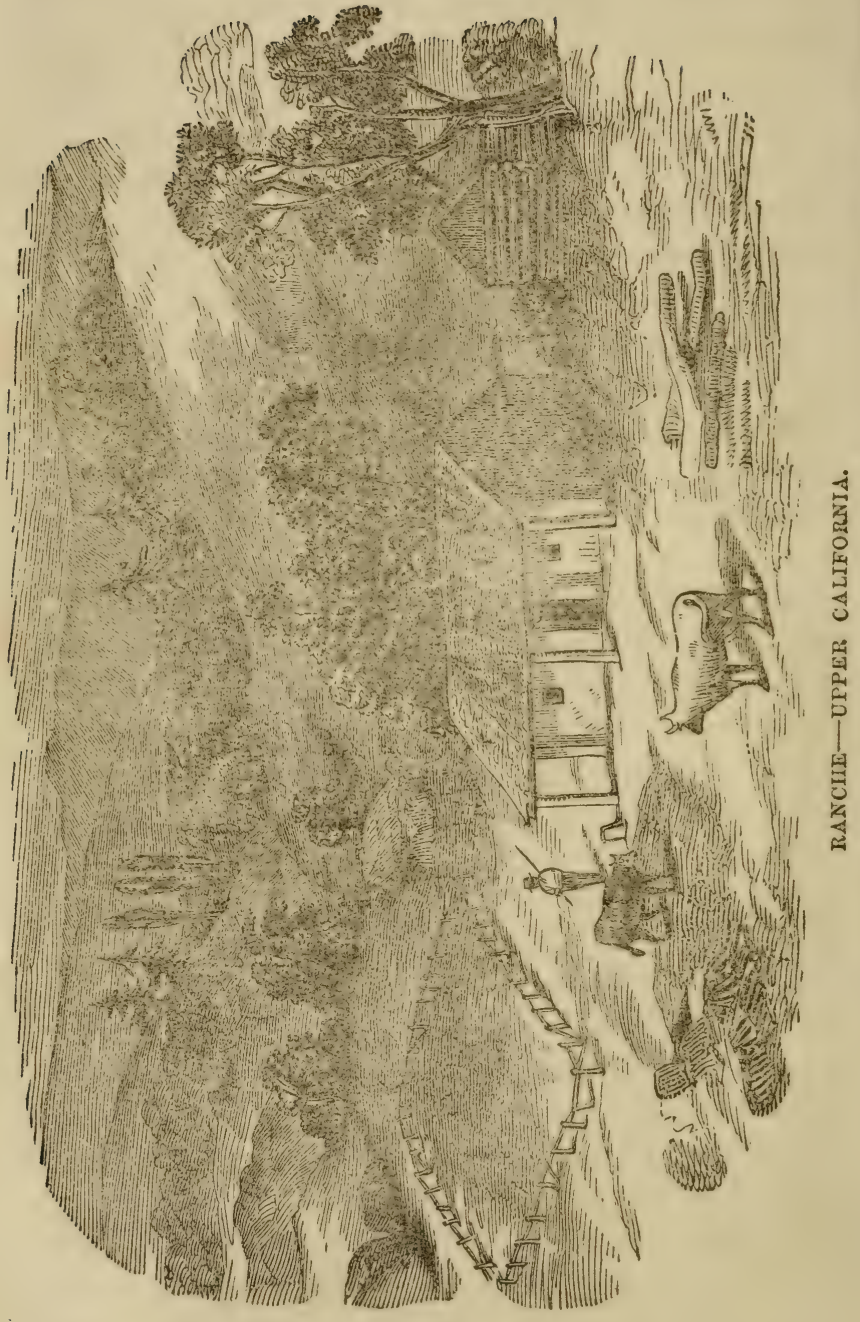


found in the Cosumnes to the south of the American Fork. In each of these streams the gold is found in small scales, whereas in the intervening mountains it occurs in coarser lumps.

"Mr. Sinclair, whose rancho is three miles above Sutter's, on the north side of the American, employs about fifty Indians on the north fork, not far from its junction with the main stream. He had been engaged about fire weeks when I saw him, and up to that time his Indians had used simply closely woven willow baskets. His net proceeds (which I kaw) were about $\$ 16,000$ worth of gold. He showed me the proceeds of his last week's work-fourteen pounds avoirdupois of clean-washed gold.

"The principal store at Sutter's Fort, that of Brannan and Cu., had receired in payment for goods $\$ 36,000$ (worth of this gold) from the 1st of May to the 10th of July. Other merchants had also made extensive sales. Large quantities of goods were daily sent forward to the mines, as the Indians, heretofore so poor and degraded, have suddenly become consumers of the luxuries of life. I before mentioned that the greater part of the farmers and rancheros had abandoned their fields to go to the mines. This is not the case with Captain Sutter, who was carefully gathering his wheat, estimated at 40,000 bushels. Flour is already worth at Sutter's thirty-six dollars a barrel, and soon will be fifty. Unless large quantities of breadstuffs reach the country, much suffering will occur; but as each man is now able to pay a large price, it is believed the merchants will bring from Chili and Oregon a plentiful supply for the coming winter.

"The most moderate estimate I could obtain from men acquainted with the subject, was, that upward of 
four thousand men were working in the gold district, of whom more than one-half were Indians; and that from $\$ 30,000$ to $\$ 50,000$ worth of gold, if not more, was daily obtained. The entire gold district, with very few exceptions of grants made some years ago by the Mexican authorities, is on land belonging to the United States. It was a matter of serious reflection with me, how I could secure to the government certain rents or fees for the privilege of procuring this gold; but upon considering the large extent of country, the character of the people engaged, and the small scattered force at my command, I resolved not to interfere, but to permit all to work freely, unless broils and crimes should call for interference. I was surprised to hear that crime of any kind was very unfrequent, and that no thefts or robberies had been committed in the gold district.

"All live in tents, in bush arbors, or in the open air; and men have frequently about their persons thousands of dollars worth of this gold, and it was to me a matter of surprise that so peaccful and quiet state of things should continue to exist. Conflieting claims to particular spots of ground may cause collisions, but they will be rare, as the extent of country is so great, and the gold so abundant, that for the present there is room enough for all. Still the gorornment is entitled to rents for this land, and immediate steps should be devised to collect them, for the longer it is delayed the more difficult it will become. One plan I would suggest is, to send out from the United States surveyors with high salaries, bound to serve specified periods.

"The discovery of these vast deposits of gold has entirely changed the character of Upper California. Its people, before engaged in cultivating their small 
patches of ground, and guarding their herds of cattle and horses, hare all gone to the mines, or are on their way thither. Laborers of every trale have left their work benches, and tradesmen their shons. Sailors desert their ships as fast as they arrire on the coast, and sercial vesseds have gone to sea with hardly enough hands to spread a sail. Two or three are now at anchor in San Francisco with no crew on board. Mlany desertions, too, have taken place from the garrisons within the influence of these mines; twenty-six soldiers have deserted from the nost of Sonoma, twenty-four from that of San Francisen, and twentyfour from Monterey. For a few days the evil appeared so threatening, that great danger existed that the garrisons would leare in a borly; and I refer you to my orders of the 2uth of July, to show the steps adopted to meet this contingency. I slall spare no exertions to apprehend and punish deserters, but I beliere no time in the history of our country has presented such temptations to desert as now exist in California.

"The danger of apprehension is small, and the prospect of ligh wages certain; pay and bounties are trifles, as laboring men at the mines can now carn in one doy more than double a soltier's pay and allowanees for a month, and eren the pay of a lieutenant or captain camut hire a servant. A carpenter or mechanic would not listen to an oficr of less than fifteen or twenty dollars a day. Could any comlinatim of affairs try a man's fidelity more than this? I roally think some extraordinary mark of faror shonlit be giren to those soldiers who remain faithful to their flag throughout this tempting crisis.

"Many private letters have gone to the United States, giving accounts of the rast quantity of gold 
recently discovered, and it may be a matter of surprise why I have made no report on this subject at an earlier date. The reason is, that I could not bring myself to believe the reports that I heard of the wealth of the gold district until I visited it myself. I have no hesitation now in saying that there is more gold in the country drained by the Sacramento and San Joaquin Rivers than will pay the cost of the present war with Mexico a hundred times orer. No capital is required to obtain this gold, as the laboring man wants nothing but his pick and shovel and tin pan, with which to dig and wash the gravel; and many frequently pick gold out of the crevices of the rocks with their butcher knives, in pieces of from one to six ounces.

"Mr. Dye, a gentleman residing in Monterey, and worthy of every credit, has just returned from Feather River. He tells me that the company to which he belonged worked seren weeks and two days, with an arerage of fifty Indians (washers, ) and that their gross product was two hundred and serenty-three pounds of gold. His share (one seventh,) after paying all expenses, is about thirty-seven pounds, which he brought with him and exhibited in Monterey. I see no laboring man from the mines who does not show his two, three, or four pounds of gold. A soldier of the artillery company returned here a few days ago from the mines, having been absent on furlough twenty days. He made by trading and working, during that time, $\$ 1500$. During these twenty days he was travelling ten or eleven days, leaving but a week in which he made a sum of money greater than he receives in pay, clothes, and rations, during a whole enlistment of five years. These statements appear incredible, but they are true. 
"Gold is also believed to exist on the eastern slope of the Sierra Nevada; and when at the mines, I was informed by an intelligent Mormon that it had been found near the Great Salt Lake by some of his fraternity. Nearly all the Mormons are leaving California to go to the Salt Lake, and this they surely would not do unless they were sure of finding gold there in the same abundance as they now do on the Sacramento.

"The gold 'placer' near the mission of San Fernando has long been known, but has been little wrought for want of water. This is a spur which puts off from the Sierra Nevada (sce Fremont's map,) the same in which the present mines occur. There is, therefore, every reason to beliere, that in the intervening spaces, of fire hundred miles (entirely unexplored) there must be many lidden and rich deposits. The 'placer' gold is now substituted as the currency of this country; in trade it passes frecly at $\$ 16$ per ounce; as an article of commerce its ralue is not jet fixed. The only purchase I mark was of the specinen No. 7, which I got of Mr. Neligh at 812 the ounce. That is about the present cash ralue in the country, although it has been sold for less. The great demand for roods and provisions, made by this sudden development of wealth, has increased the amount of commerce at San Francisco very much, and it will continue to increase."

The Galiformian, published at San Francisco on the 14th of August, furnishes the following interesting account of the Gold Region:

"It was our intention to present our renders with a description of the extensive gold, silver, and ivon mines. recently diseovered in tho Siema Nevada, together with some other important items, for the good of the people, but we aro compelled to defer it for a future 
number. Our prices current, many raluable communication, om menine joumal, aud other important matters, lare al:o been crowried ont. But to enable Our distant rualers to diaw some ilien of the extent of the eoll nine, we will confine our remarks to a few ficts. The country from the 1 juba to the San Joaruin rirers, a distance of about one hundred and twenty miles, and from the base toward the summit of the mountains, as far as Snow Iill, about serenty miles, lins been explored, and gold found on erery part. There are now probably 3000 people, including Indians, engaged collecting gold. The amount collected by each man who works, ranges from 810 to $\$ 350$ per diny. The publisher of this paper, while on a tour alone to the mining district, collected, with the aid of a shorel, pick and tin pan, about twenty inches in diameter, from 814 to 8128 a day-areraging $\$ 100$. Tho gross amount collected will probably exceed $\$ 600,000$, of which amount our merchants have reccived about 8250,000 worth for goods sold ; all within the short space of eight werks. The largest pice of gold known to be found reighed four pounds.

"Labor has erer been high in California, but previous to the discorery of the placera goll, the rates ranged from $\$ 1$ to 93 per day. Since that epock common labor cannot be obtaincr, and if to be hail, for no less price than fffy cents per hour, and that tho most common. Compenters and other mechanics have bern afued etó a lay, but it Ines bean flatly refuect,

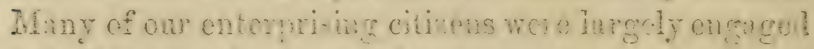
in builling, and on hors wish to cominance on dwellings, warchouses, and the liks, but all hare hat to suspent for the lack of thet all inportant class of community, the working men." 
The following extracts from the published journal of a physician in California, give accounts of the reception of the news of the gold discovery in San Francisco, with its consequent effects.

" May 8th.-Captain Fulsom called at Sweeting's to-day. He had seen a man this morning, who reported that he had just come from a river called the American Fork, about one hundred miles in the interior, where he had been gold washing. Captain Fulsom saw the gold he had with him; it was about twenty-three ounces weight, and in small flakes. The man stated that he was eight days getting it, but Captain Fulsom hardly believed this. He says that he saw some of this gold a few wecks since, and thought it was only 'mica,' but good judges have pronounced it to be genuine metal. He talks, howerer, of paying a visit to the place where it is reported to come from. After he was gone, Bradley stated that the Sacramento settlements, which Malcolm wished to visit, were in the neighborhood of the American Fork, and that we might go there together; lie thought the distance was only one hundred and twenty miles.

"May 10th.-Yesterdas and to-day nothing has been talked of but the new gold 'placer,' as people call it. It seems that four other men had accompanied the person Captain Fulsom saw yesterday, and that they had each realized a large quantity of gold. They left the 'diggings' on the American Fork, (which it seems is the Rio de los Americanos, a tributary to the Sacramento) about a weck ago, and stopped a day or two at Sutter's Fort, a few miles this side of the diggings, on their way; from there they had travelled by boat to San Francisco. The gold they brought has been examined by the first Alcalde here, and by 
all the merchants in tho place. Braclley showed us a lump weighing a quarter of an ounce, which he had boughtit of one of the num, and for which he gave lim three dollurs and a half. I have io doubt in my own mind about its boing genuine golle. Sereral partics, we hear, are alreaty male up to visit the diegings; and, acopoling to the newplaper here, a number of people have actmally startcul off with shorels, matocks, and pans, to dig the gold themselves. It is nut likely, howerer, thet this will be allowel, for Captain Fulsm lins alrouly writien to Colonel Maron alout taking posscssion of the mine on belalf of the government, it being, as ho says, on public land.

"Mey 17th.- This place is wow in a perfeet furer of crcitement; all the worli-people hare struck. Walling through the town to-day, I observed that laborers were employed cnly upon ahout half-a-1o:(in of the fifty new buildings which were in the comre of l,eing run up. The majority of the mechanics at this place are making proparations for moving ofl to the mines, and several inmetred people of all classes-lawyers, store-keepers, merchants, de.,- -are bitten with the ferer; in fact, thore is a regular gold maria springing uip. I comted no less than cighten louses which were closed, the owner's having left."

The mania cominued to increase, and within a few months all the principo? towns were nearly emptied of their population. Grold was the unirersal object, and splemlid and rapid fortune the unirersal hop? No oecupation secmed to offor swah a prospect as thet of ligeing goll, and accordingly, thowe who were ont able to bear the fatigues of such work, of were at tho head of any sort of business in the lifferent towns, had to pay enormous prices for the labor of subordinates 
who performed the meanest services. The prices of all agricultural and manufactured products became treble the previous rates.

Soon came the furst wares of the tille of emigration that was to firoul the placers of the gold region. The frrat infux consistel of Mexicans of the province of Somoma, Chilizns, and some few Chinese. These, principally took possession of the southern mines, or those on the San Joarnin and its tributaries. Some fow stopped at San Francisco, and sccured lots of ground which they knew would become very valualle in a short time, and erected temporary stores and dwellings. This gave the impulse to the progress of the town, and it soon advanecd rapidly in size and population. Then came the emigration from the Atlantic States of the Union, and the whole territory felt the progressive and cuterprising spirit of the goldseckers. Tho Amerieans generally took possession of the mines upen the northern tributaries of the Sacramento Rirer; but as their numbers increased they pushed towards the southern mines, and frequent cullisions with the forcigners were the consequence. Finally, a great number of the latter wore compelled to leave the country. 


\section{CHAPTER VII.}

ADVENTURES OF SOME OF TIIE MINERS, AND INCIDENTS CONNECTED WITI MINING.

Tre adventures of the eager gold-seekers in the region of their hopes, among the washings and the diggings of the placers, cannot but be interesting. The toil to which the men have to submit if they would ohtain any thing like a satisfaction to their desires, is of a very irksome character. In the summer season, the heat is intense, and the principal part of the labor of washing and digging must be performed exposed to the full blaze of the sun. In the "dry diggings," the miners suffer greatly from the want of water. Most of the provisions having to be transported from the towns on the Sacramento and San Joaquin, soon grow unwholesome from exposure to the sultry air of the day and the damp air of the night. This diet, conjointly with the exposure of the miners, tends to produce intermittent fever and dysentery. The miners generally reside in huts of a rude construction, or in canras tents, which afford but poor protection from the changes of the weather.

The most prominent man in the neighborhood of the "diggins," is Captain Sutter, the Daniel Boone of that part of the country. He was formerly an officer in the Swiss guards of Charles X. of France. After the revolution of 1830 , in that country, he cam to the United States. Emigrating to California, he obtained a grant of land from the Mexican govern. 
mont, and founded the settlement known as Sutter's Fort. Upon his land, the first discovery of the richness of the soil was made, and his house and the settlement around it has been, ever since, the resort of persons going to and from the placers, and a depot for provisions and articles used by the miners. Stores and workshops have been established, and a considerable amount of business is transacted there. Captain Sutter is held in very great respect by the people of the settlement and those stopping at his house on the road to the placers. Several versions of the account of the discovery of the gold mines have been circulated, but the true one, in the Captain's own words, is given in a work recently publisherl.* The account is here inserted, both on account of the interest connected with the discovery, and in order to correct wrong versions of the matter.

"I was sitting one afternoon," said the Captain, "just after my siesta, engaged, by-the-bye, in writing a letter: to a relation of mine at Lucerne, when I was interrupted by Mr. Marshall-a gentleman with whom I had frequent business transactions-bursting hurriedly into the room. From the unusual agitation in his manner, I imagined that something serious had occurred, and, as we involuntarily do in this part of the world, I at once glanced to see if my rifle was in its proper place. You should know that the mere appearance of Mr. Marshall at that moment in the fort was quite enough to surprise me, as he had but two days before left the place to make some alterations in a mill for sawing pine planks, which he had just run up for me, some miles higher up the Ameri-

* Four Months Among the Gold Finders of California, by J. Tyrwhit Brooks, M. D. 
canos. When he had recovered himsclf a little, he tolil me that, howerer great my surpurise might be at his mexpecterl reappearance, it would be much greater when I heard the intelligence he harl come to bring me. 'Intelligence,' he adter, 'which, if properly profited by, would put both of us in possession of unhearl-of wealth-millions and millions of collurs, in fact.' I frankly own, when I heard this, that I thought something had touched Marshall's brain, when suldenly all my mischivings were put an end to by his flinging on the table a handful of scales of pure rirgin golil. I was fairly thunderstruck, and asked him to explain what all this meant, when he went on to say, that, according to my instructions, he had thrown the mill-wheel out of gear, to let the whole body of the water in the dam find a passage through the tail-race, which was previously too narrow to allow the water to run off in suflicient quantity, whereby the wheel was prerented from efficiently performing its work. By this alteration the narrow channel was considerably enlarged, and a mass of sand and gravel carricd off by the force of the torrent. Early in the morning after this took place, he (Mr. Marshali) was walking along the left bank of the stream, when he perceived something which he at first took for a piece of opal-a clear transparent stone, very common here-glittering on one of the spots laid bare by the sudden crumbling away of the bank. He paid no attention to this; but while he was giring directions to the workinen, having observed screral similar glittering fiarment, his curiosity was so far cxcited, that he stooncil down and picked one of them up. 'Do Jou know' sail Mr. Marshall to me, 'I positively debated within myself two or three times whether I should take the trouble 
to bend my back to pick up one of the pieces, and had decided on not doing so, when, further on, anmher glitcring morsel canght my eye-the largest of the pimes now before you. I cundescended to pick it up, and to my astonishment found that it was a thin scale of what alpears to be pure gold.' The then gatherect some twonty or thirty similar picces, which on exaluination convined him that his suppositions were right. Ilis first impression was, that this gold had been lost or huried there by some early Indian tribe-perhaps some of thuse mysterious inlubitants of the West, of whom we have no account, but who dwelt on this continent centuries ago, and brilt those cities and temples, the ruins of which are scattered abont these solitary wills. On proceeding, howerer, to examine the noighboring soil, he discovered that it was more or less aurifer ous. This at once deciled him. He mounted his horse, and rode down to me as fast as it would carry him, with the news.

"At the conclusion of Mr. Marshall's account," continued Captain Sutter, "and when I had convinced myself, from the specimens he had brought with him, that it was not exaggerated, I felt as much excited as himself. I eagerly incuired if he had shown the goll to the work people at the mill, and was glad to hear that he had not spoken to a single person about it. We agreed," sail the Captain, smiling, "not to mention the circumstance to any one, and arranged to set off enrly the noxt diy for the nit, On om arriral, just befure sunluwn, we polsod the sand al.ont in variuts places, and before long succooldel in collewting between us, more than an ounce of golk, mixed up with a good deal of sanct. I stayed at Mr. Marshall's that night, and the next day we proceeded some little 
distance up the South Fork, and found that gold existed along the whole course, not only in the bed of the main stream, where the water had subsided, but in every little dried-up creek and ravine. Indeed, I think it is more plentiful in these latter places, for I myself, with nothing more than a small knife, picked out from a dry gorge, a little way up the mountain, a solid lump of gold which weighed nearly an ounce and a half.

"On our return to the mill, we were astonished by the work-people coming up to us in a body, and showing us small flakes of gold similar to those we had ourselves procured. Marshall tried to laugh the matter off with them, and to persuade them that what they had found was only some shining mineral of trifling value; but one of the Indians, who had worked at the gold mine in the neighborhood of La Paz, in Lower California, cried out, 'Oro! oro!' We were disappointed enough at this discovery, and supposed that the work-peoplc had been watching our movements, although we thought we had taken every precaution against being observed by them. I heard, afterwards, that one of them, a sly Kentuckian, had dogged us about, and that, looking on the ground to see if he could discover what we were in search of, he had lighted on some flakes of gold himself.

"The next day I rode back to the Fort, organized a laboring party, set the carpenters to work on a few necessary matters, and the next day, accompanied them to a point of the Fork, where they encamped for the night. By the following morning I had a party of fifty Indians fairly at work. The way we first managed was to shovel the soil into small buckets, or into some of our famous Indian baskets; then wash 
all the light carth out, and pick amay the stones; after this, we dried the sand on pioces of canras, and with long reels hlew away all but the goll. I have now scrme: rude machines in use, and upwarcis of one humled men employed, clichr Indians, who are well fed, and who are allowed whisky thince times a day.

"I'he report soon spread. Some of the cold was sent to fan Francisen. and crowils of people flocked to the diggings. Arluterl to this, a large emimmant party of Mormons entered Califomia across the liocky Momtaina, just as the afair was first mate known. They halied at once, anil set to work on a spot some thinty miles from here, where a few of thom still remain. Whon I was last up to the diggings, there vere full eight hundred men at work, at one place and another, with perha1s something like three hundred more passing backwarts and forwarls between liore and the mines. I at first inngined thut the solit would soin be exhausted by sueh crowds of seckers, but sulserpent observations have convinced me that it will take many years to bring about such a result, eren with ten times the present numbor of neoplo employed.

"What surprises mr," continued the Captain, "is, that this country should have been visited by so muny soientifie men, and thet not one of them shombl here ever stumblet unon the treusmes: thut sumes of Econ eyent truplers shoull hure emesan? this rolloy in

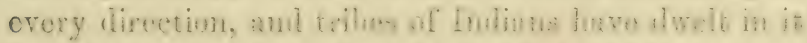

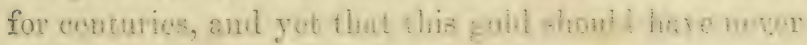

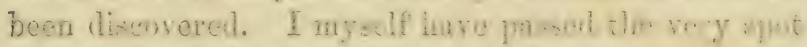

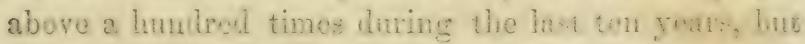
was just as blind as the rest of them, on I must not wonder at the discorery not haring been made carlier." 
The plan of operations adopted by most of the miners who were not Indians or Californians, was to form bands of three, five or ten, under the command of one of the number, whose name the party took, and by which it was afterwards known. Some larger companies were formed in the United States, and repaired to California, and their operations were of course, on a more extensive scale; they haring all the necessary equipments of gold-washers and miners. Written rules were generally drawn up for the government of the parties, varying in particulars according to the peculiar views of the framers. These rules provided for the modus operandi of procuring the gold, supplying the party with necessaries, attending to the sick, and the division of the fruits of their labor.

One of the most frequented placers of California is called the Stanislaus mine, situated near the Stanislaus River. It was one of the first places worked to any extent by the gold-seekers, but not satisfying the expectations of some of the most greedy, it has since been partially abandoned. A description of this mine, and of the living and operations of its workers in the winter of 1848-49, will give a good general idea of the toils and privations endured by the early gold-seekers in that region, and, also, of their mode of procuring the precious metal at most of the mines. We extract from a recently published work, distinguished for minuteness of detail and accuracy of description.*

"The mine was a deep ravine, embosomed amidst lofty hills, surmounted by, and corered with pine, and having, in the bottom itself, abundance of rock, mud, and sand. Halliday and I encamped at the very

\footnotetext{
* Personal Adventures in Upper and Lower California, by William Redmond Ryan.
} 
lorrest part of the ravine, at a little distance from Don Emanucl's party; a steep rock which towered abore our hearls affording us shelter, and a huge, flat stone beneath our feet promising a fair substitute for a dry bed. ITere then we stretched our macheers and blankets, and arranged our saddles and bags, so as to make ourselves as comfortable and warm as possible, although, in spite of our precautions and contrivances, and of a tolerably good fire, our encampment was bitterly cold, and we lay exposed to a heary dew. We had given up our horses into the charge of the Indians, and I saw to their being safely placed in the cavallard, whilst IIalliday went to chop wood; a task I was too weak to perform. I cannot say we slept; we might more correctly be said to have had a long and most uncomfortable doze, and when morning broke, we were shivering with coll, and shook the dew in a shower from our clothes. I consulted with my companion, and urged upon him the prudence of our setting to work to construct ourselves a sort of log cabin; otherwise I felt certain, from the experience of the past night, our sojourn at the mines would be likely to prore fatal to one or both of us. Ho was, however, far too eager to try his fortune at digging to listen to my proposal, at which he even smiled, probably at the bare idea of weather, privation, or toil, being able to affect his powerful frame. I saw him presently depart up the ravine, shouldering a pick, and glancing now and then at his knife, whilst I proceeded in search of materials for constructing a temporary place of shelter.

"As my strength was unequal to the task of felling timber, I endearored to procure four poles, intending to sink them into the ground, and to stretch on the 


\section{top of them a bed-tick I had reserved for the purpose.}

The contrivance was a sorry one at the best, but shelter was indispensable; and great was my disappointinent-though I procured the timber after a painful search-oto find that the rocks presented an insuperable olstacle to my employing it as $I$ intended. My efforts to sink the poles proved utterly futile, and I was at last compelled to renourice the attempt in despair. I then packed ui) our soods into as close a compass as possible; and, having requested one of the Spaniards in Don Emanuel's party to keep watch over them, departed to explore the ravine.

"Within a few paces of our cncampment there was a large area of ground, probably half a mile square, the surface of which consisted of dark soil and slate, and was indented with innumerable holes of every possible dimension, from six inches to as many feet or more, wide and deep. In all of these lay abundance of water, of which large quantities are to be found $₫$ little beneath the surface, the rarine bcing supplicd with it in great abundance by the rains that pour down from the hills during the wet season. Tho the extrene right of our camp, the ground assumed a more rocky character; ankl, from the rast deposit of stagnant water, did not secm to offer many attractions to the miners. Let there was scarcaly a spot in any of these places where the crow-lar, the pick, or the jack-knife, had not been busy: cridence that the whole locality mest hare been extrenely rich in the precious motal, or it would not liave been so theronghly norked.

"In crossing the ravine, I was obligerl to leap from one mound of earth to another, to aroil plunging ancle-deep in mud and water. It was wholly deserted 
in this part, thorgh formerly so much frequented; and, with the exception of a few traders, who, having taken up their station here when times were good, had not Jet made arrangeinents for remoring to a more productive place, not a soul was to be seen.

"I walked on until I reached the trading-post of Mr. Andersoin, formerly our interpreter in the Lower Country, whom I felt delighted to meet with again. His shed was situated in one of the dampest parts of the mine, and consisted of a few upright poles, trarersed by cross-pieces, and covered in with raw hides and leares, but yet much exposed at the sides to the wind and the weather. He had a fow barrels of flour and biscuit, which he retailed at two dollars a pound; for he made no difference between the price of the raw and the prepared material. The flour would go further, it was true; but then the biscuit required no cooking on the part of the miner, whose time was literally money, and whose interest therefore it was to economize it in every possible manner. Fie also sold unprepared coffee and sugar at six Tankee shillings a pound; dried beef at one dollar and a half; and pork, which was regarded as a great delicacy here, at two dollars for the same weight. The rarious articles of which his stock-in-trade consisted he had brought all the way from Monterey at consilerable labor and expense; lut, by the exercise of extraordinary tact, persererance, and industry, he had succeeded in establishing a flourishing business.

"I discovered, however, that he possessed another resource-by which his gains were marvellously increased-in the services of seven or eight Indians, whom he kept constantly at work, in the rear of his shed, digging gold, and whose labor he remunerated 
with provisions, and occasional presents of articles of trifling value to him, but highly esteemed by the Indians. They were watched by an American overseer, who was employed by him, to assist in the general business, particularly in slaughtering; for, as beef was scarce, he used to send his man in quest of cows and oxen; which he killed, cut up, salted and dried, in his shed, and watching the most favorable moment for the operation-namely, when meat could not bo procured at the 'diggins'-never failed to realize his own price for it.

"Proceeding higher up the ravine, I observed a large tent erected on the slope of a hill, within a few yards of the bottom, where the gold is usually found. It was surrounded by a trench, the clay from which, as it was dug up, had apparently been thrown out against the canvas, forming a kind of embankment, rendering it at once water and weather-proof. I ventured into it, encountering on my way an immense piece of raw beef, suspended from the ridge-pole. Upon some stones in front, inclosing a small fire, stood a frying-pan, filled with rich looking beef collops, that set my mouth watering, and severely tested my honesty; for, although acorns are all very well in their way, and serve to stay the cravings of the stomach for awhile, I did not find my appetite any the less sharp, notwithstanding the quantity I had eaten. But I resisted the temptation, and penetrated further into the tent. At one side of it lay a crow-bar, and an old saddle that had seen rough service; yet not a soul appeared, and my eyes were again ogling the collops, whilst an inward voice whispered how imprudent it was to leave them frizzling there, when, all at snce, a little man, in a 'hickory shirt,' with his face 
all beclaubed with pot-black and grease, darted out of some dark corner, flourishing in one hand a long bowie knife, and in the other three by no means delicate slices of fat pork, which he at once dropper into the frying-pan, stooping down on one linee, and becoming immediately ahsorbed in watching the interesting culinary process then going on in it.

"I came up next with a group of three Sonomeans, Or inhabitants of Sonoma, busily engaged on a small stinly flat-the only one I had observed-at the bottuin of the ravine. There was no water near, although I noticel several holes which had evidently been sunk in quest of it. These men were actirely pursuing a process that is termed 'dry-mashing.' One was shorelling up the sand into a large cloth, stretched out upon the ground, and which, when it was tolerably well coreren, he took up by the corners, and shook until the peblles and larger particles of stone and dirt came to the surface. These he brushel away carefully with his hand, repeating the process of shaking anil clearing until the residie was sufficiently fine for the next operation. This was performed by the other men, who, depositing the sand in large bowls hewn out of a solid block of wood, which they held in their hanls, dexterously cast the contents up before them, abont four fect into the air, catching the sand again very cleverly, and blowing at it as it descerded. This process being repeated, the sand gradually disanpeared, and from two to three ounces of pure gold remained at the bottom of the bowl. Easy as the operation appeared to me to be, I learned, upon inquiry, that to perform it successfully required the nicest management, the greatest perseverance, and especially robust lungs. The men I saw had lighted 
upon a productive sand; but very often, indeed, those who adopt this mode of gold washing toil long at barren soil before they discorer the uselessness of laboring thus arduously.

"I noticed, that although the largest proportion of the gold obtained in this manner presented the appearance of a fine powder, it was interspersed, here and there, with large scales of the precious deposit, and with a few solid lumps. The metal was of a dingy hue, and, at a cursory riew, might easily have been mistaken for particles of yellow clay, or laminx of stone of the same color. The Sonomeans placed the product of their labor in buckskin bags, which were hung around their necks, and carefully concealed inside of their shirts. They work in this fashion at the mines in their own country; but I doubt if any other than a native constitution could rery long bear up against the peculiar labor of 'dry-washing' in such a climate and under such difficult circumstances. I felt half tempted to try the process myself, for the surface of this sandy bed was literally sparkling with innumerable particles of the finest gold, triturated to a polish by the running of the waters-as I conjectured; but I soon discorered how fruitless my efforts would be. Had I possessed any chemical agents at hand, however, I might soon have exhausted the bed of its precious contents, and should, doubtless, have realized an immense weight of the metal of the very purest quality.

"I may as well mention here, that of the rarious new machines manufactured and sent out to California for the purpose of digging and washing gold, tho great majority have been found quite useless. There are two or three of them, however, that have been 



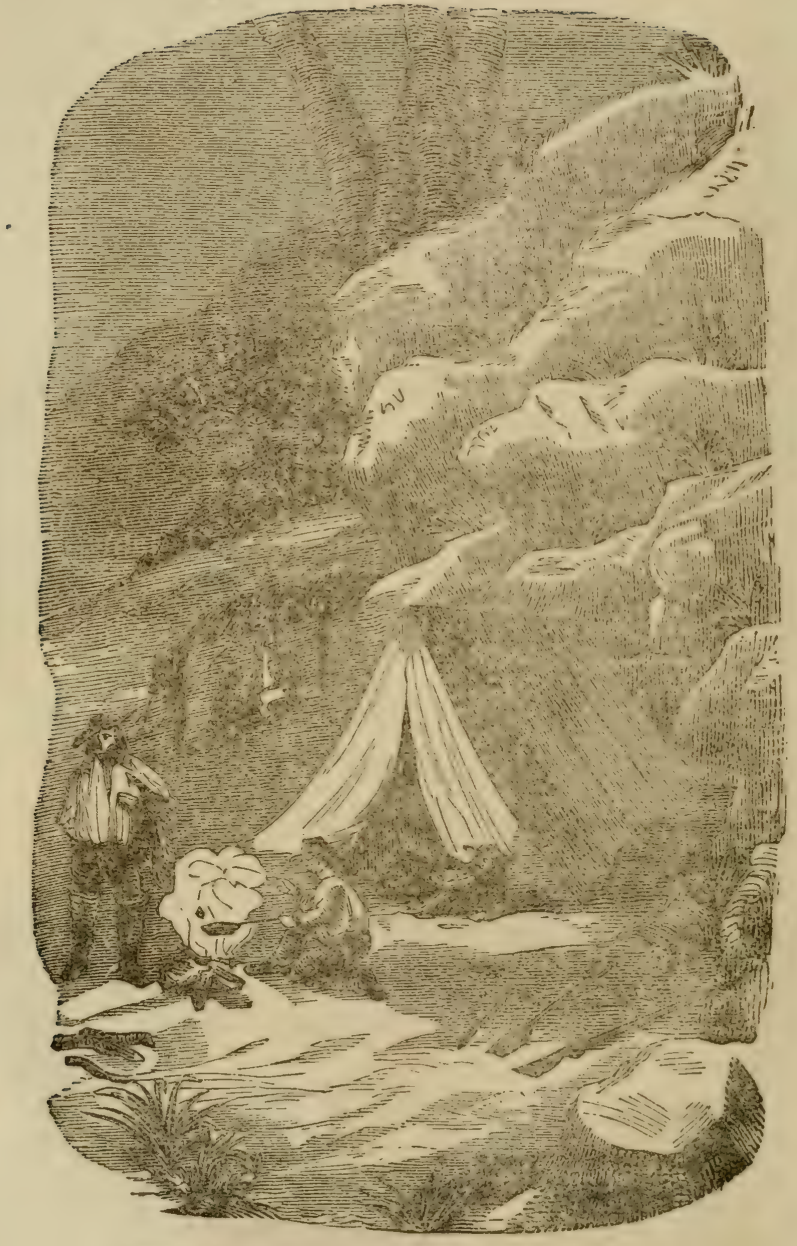

IIFE AT THE "DIGGINGS," - SUPPER TIME. 


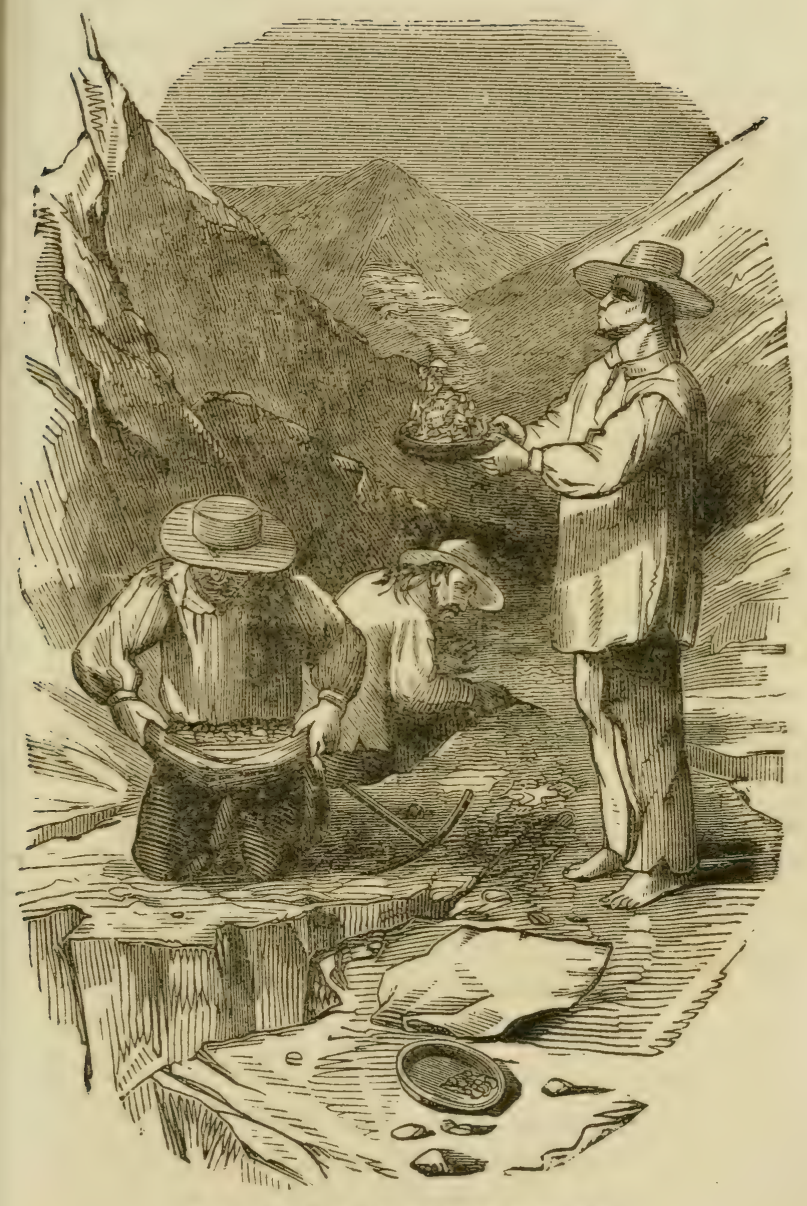

SONORIANS DRY-WASHING GOWD. 

employed with great success. I have made a sketch of those most in use amongst the diggers, as my readers may feel desirous of acquainting themselves with the latest improvements introduced in the art of mining, as practised in this country. They consist, in the first place, of the washing-rocker, or 'cradle,' which has, in numerous instances, formed the model for ruder machines, constructed by the miners themselves, whilst in the mountains. The lid, at the bottom of which lie the holes through which the gold and soil pass, is fastened by hinges at the back, in order that it may be raised up, the more readily to throw off, from time to time, the stones that accumulate. Three men are required to work this rocker with success, and there are few processes in which a smaller number could operate without extraordinary labor. One person throws the soil upon the lid, another pours on the water, whilst a third is engaged in rocking the cradle by the handle attached to it for the purpose. In this way these men keep each other constantly employed; and, indeed, this cradle, like its prototype, has often proved the bond of union between individuals who would otherwise have separated, for this simple reason, that one man could not work it half so profitably alone. The cross pieces, observable at the bottom, serve to intercept the gold as it flows towards the smaller end of the machine, whilst the dirt is carried off by the admixture with the water produced by the continual 'rocking.' As the earth becomes thoroughly dissolved, the gold naturally gravitates to the bottom; and thus it is impossible for any but the very finest particles of the ore to escape.

"The second machine, in importance, is the goldborer. It is particularly useful in examining the 
bottom of streams, and consists of a short conical cylinder at the end of a long handle, containing inside, at its lower extremity, a valve, arranged so as to admit the earth and gold, and prevent their escaping when the receptacle is full. This instrument is used in the same manner as an augur. The third machine, the pan, is also of late introduction, but has been found rather too deep for the purpose for which it is intended.

"Notwithstanding the success which seemed to attend the labors of the Sonomeans, I subsequently discovered that the entire quanity of gold thus painfully obtained, disappeared at the gambling-stalls. They were generally clad most wretchedly, many of them wearing nothing more than a dirty shirt, a pair of light pantaloons, and the wide sombrero peculiar to the inhabitants of this country and Mexico. Some few sported a serapa, but they were men of superior native rank, of which this garment is a distinctive characteristic.

"Continuing my route up the ravine, I met a man named Corrigan, galloping along with two fine horses, one of which he was leading. He stopped as soon as he recognized me, and we were soon engaged in a very interesting conversation respecting the doings at the 'diggins.' The substance of his information was, that he had made a great deal of money at the mines by digging, but infinitely more by speculation. He thought of buying a ranché, marrying, and settling down. He was then going to seek for pasture for his horses; and, bidding me a hasty good-bye, galloped off, and soon disappeared.

"As I advanced, the ground became drier and more sandy, rock and slate of various kinds abounding; 


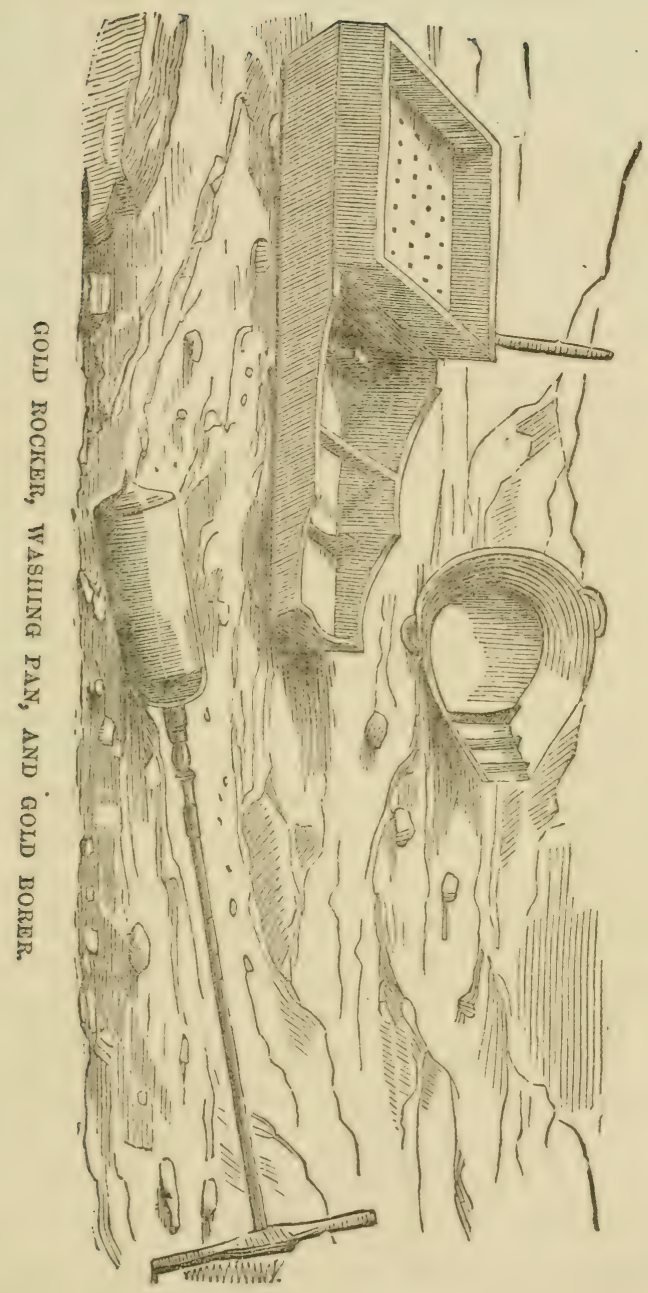



some quite soft and friable, yielding readily to the pickaxe or the crowrtar; and, in other places, so hard as to resist the utmost strength of the miners. Several of the diggers were perseveringly exploring the localities where the rotten sorts of slate were found in the largest quantities, and I saw them pick out a good deal of gold with thair jack-knires. Their principal aim was to discover what they tormod 'a pocket,' which is nothing more than a crevice between the blocks of slate, into which a deposit of gold has been washed by the heary rains from the higher districts, and which, soon accumnlating, swell into rapid torrents, which rush down these ravines with extraordinary swifness and force, sweeping every thing before them.

"There din not appear to be many mining parties at the Stanislons at this particular period, for the encampments were generally from two to five miles apart, the space between them increasing the higher you adranocd towards the mountains, to the foot of which the ravine extended-altogether, a distance of many miles. The lower part of the mine, I concluded from this fact, to bo by far the richer, simply from the ciroumatance I hare mentioned; richer, conparatively, hecano liere tho deposits of gold are more easily found ond extracted: not richer, in reality, as the metal and exivt in immense quantities in the upper regions, from which it is washed down by the rains and fonits inte tles lower districts. The virgin deposit wouth, douhlinss, be diflicult to come at; but, if sought aftur at all, that it is to be sought in the mountains and hich lande, I feel persuaded.

"I turned back, alter prosecuting my excursion until the rarine became a?most too rocky to allow me 
to proceed, and until I saw that the 'diggins' diminished materially in number. On clambering the hills at the side, I beheld abundance of pines, oak, cedar, and palm; but no grass, nor vegetation of any other kind, save prickly shrubs, with here and there a patch of extremely dry moss. On my way back, I passed several tents and huts erected by the miners, all of the very poorest and most wretched description.

"I found Van Anker's party at dinner, in front of their tent. Van showed me a leathern bag, containing several pounds' weight of very pure gold, and which was carelessly tossed about from one to the other for examination. It was the produce of his morning's work, he having fortunately struck upon a large pocket.

"On inquiring whether, as there existed such strong temptation, robberies were not very frequent, I was informed, that, although thefts had occurred, yet, generally speaking, the miners dwelt in no distrust of one another, and left thousands of dollars' worth in gold dust in their tents whilst they were absent digging. They all felt, intuitively, that honesty was literally the best policy, and a determination to punish robbery seemed to have been come to by all as a measure essential to the security and welfare of the mining community, independent of any question of principle.

"Gambling and drinking were carried on, I found, to a most demoralizing extent. Brandy and champagne, whenever they were brought to the 'diggins,' realized enormous prices, varying from sixteen to twenty dollars a bottle; and some of the men would, after accumulating some hundred dollars, squander the whole in purchasing these beverages. Believing the 
supply of gold to be inexhaustible, they persisted in this reckless course, and discovered only when it became too late to redeem their error, that eren here gold cannot always be procured. They went on until the placers failed to yield, and were then reduced to great extremities.

"The miners were by no means averse to lending 'dust' to those who required it, notwithstanding that the lenders often experienced some difficulty in getting back the adrance. One of Van's party, for instance, lent another six ounces of gold, which not being returned at the stipulated period, nor for some time afterwards, he dunned his debtor at every meal, until the latter, who had quietly submitted to the importunity, begged him to 'just wait ten minutes, and time it.' He shouldered his pickaxe, as he said this, and going out of the shed, returned within the time, bringing back more than sufficient to liquidate the debt. This little incident created much amusement."

The whole of the gold region lies between the San Joachin and Sacramento Rivers and the California range of mountains. The principal mines are the Towallomie, the Stanislaus, the Macalamo, the Merced, Fremont's Diggings, or Mariposa, the Calaveras, the Macassime, the South, Middle, and North Forks, Bear Creek, Yuba, Feather River, and the Sacramento. The mines are nothing more than so many ravines, which run across from the range of mountains, and are flooded by the torrents which pour down from the upper region during the rainy season, and which have been supposed to bring the gold down with them.

The Nacalamo Dry Diggings is considered one of the richest placers in the gold region. It is a long ravine, the soil of which is red, and sometimes blueish 
in places, sand predominating. The blue clay is thought to be the richest by the diggers. The sides of the ravine are so steep and irregular, that the miners are troubled to find resting places of a night. The gold taken out of this mine runs large; the average size of the lumps being that of a pea. Pieces have been taken out of it that weighed above two pounds.

Instances of robbery and murder have not been few in the gold region, as might be conjectured from a knowledge of the motley character of the miners, and the temptations offered to araricious spirits. Yet, all things considered, the number of instances will not appear so very extraordinary. Lynch law, the only resort of the wronged in pocket, or the friends of the murdered, exercised its terrible power, and tended to prevent the crimes that would, otherwise, have been frequent. An instance of this summary justice we here relate, to illustrate the means by which the miners protected their lives and property.

"A sailor, a deserter from the Ohio, took it into his head, one night, to rob one of the volunteers, who had set up a drinking store. He had already got two bags, containing about five thousand dollars' worth of gold; but, not satisfied with them, grasped at a third, half full of dollars in silver. The jingling of the coin awoke the owner, who, springing up, gave the alarm, and, after a hot pursuit, the thief was captured, and bound to a tree until morning. At about nine, a jury of twelve miners sat to consider the case, a volunteer named Nutman officiating for Judge Lynch. Of course, he was found guilty, and sentenced to be hanged; but, some opposition being raised to depriving him of life, and a milder punishment suggested; it was finally determined that he should receive a hundred 
lashes on his bare back, have his ears cut off, and his head shared, so that he might be every where recognized in the mining districts. This sentence gave general satisfaction. The poor wretch was at once fastened by his hands to the branch of a tree, and the fellows procecded to shave his head, whilst some sailors of the party set to work manufacturing cats. Iis feet were then tied together to the foot of the tree, and when his head had been shaved, a doctor lopped off his ears. Ile bled a good deal; but, when the blood was staunched, they set to flogging him, and they didn't spare him either. After this, they kicked him out.

"Ycll, he went ofi, and when he was about half a mile away, stole a male, and rode orer to the 'Calareras' digcins, where the animal was claimed by the omner. Ihe was thereupon tried for mule-stealing, and sentenced to receire another flogeing; but when the miners came to strip him, they found his back so shockingly cut up, that they took compassion on him, and contented themselves with driving him out of the district, where he never appeared again."

During the summer season, when exposure and labor in the mines, together with unwholesome food, produce a great prevalence of fever and dysentery, the natire Californians make use of a singular remedy. It is enled the twinaseal; being a sort of hot air bath, slaped something like a sentry-box. It is built of wicker-work, and afterwarls plastered with mud until it becomes air tight. The mode of application of this remedy is as follows:- $\perp$ large fire is built ciose up to the door of the structure-a narrow aperture, just large enough for a man to squeeze through. This is allowed to buin itself out, having while burning, 
heated to a very high degree the air in the interior of the box. Into this the patient screws himself, and there remains until a profuse perspiration is produced, which is checked suddenly by a plunge into the chilly waters of the river. This is of the nature of a Thompsonian remedy.

The absorbing interest with which the gold-seekers proceed in their work is admirably depicted by one of the adventurers, in a book published after his return.*

"Arriving on the bar, the scene presented to us was new indeed, and not more extraordinary than impressive. Some with long-handled shovels, delved among clumps of bushes, or by the side of large rocks, never raising their eyes for an instant; others with pick and shovel worked among stone and gravel, or with trowels searched under banks and roots of trees, where, if rewarded with small lumps of gold, the eye shone brighter for an instant, when the search was immediately and more ardently resumed. At the edge of the stream, or knee deep and waist deep in water, as cold as melted ice and snow could make it, some were washing gold with tin pans or the common cradle rocker, while the rays of the sun were pouring down on their heads, with an intensity exceeding any thing we ever experienced at home, though it was but the middle of April.

"The thirst for gold and the labor of acquisition orerruled all else, and totally absorbed every faculty. Complete silence reigned among the miners; they addressed not a word to each other, and seemed averse to all conversation. All the sympathies of common

* Sights in the Gold Region, or Scenes by the Way, by Theodore T. Johnson. 
humanity, all the finer and noble attributes of our nature seemed lost, buried beneath the soil they were eagerly delving, or swept away with the rushing waters that revealed the shining treasure."

This extract is suggestive of considerable reflection. The same amount of attention given to any pursuit must produce results equally as satisfactory as that given to gold-seeking. But gold carries with it such obrious enjoyments to the grosser minds, that the pursuit of it alone can attract their attention sufficiently to effect any thing considerable. Could the pure enjorments connected with the practice of virtue be made as obvious to all minds, the result would be something at which the philanthropist might rejoice.

The extremes of heat and cold, during the summer, in the valleys and cañons of the gold region, are very remarkable. From nine o'clock in the morning till five in the afternoon, the heat is almost intolerable. The sun's rays pour down through an atmosphere clear and dry, and their power is increased by reflection from the sides of the cañons and mountains, and from the surface of the streams. During the night, the air becomes so cold as to render blankets very serviceable. This is caused by the waters of the different streams rising during the night, their volume being increased by the melting of the snows of the Sierra Nevada, by the heat of the previous day.

Thousands of Indians, belonging to the Snake, Shoshonee, and Crow tribes, are at work at the mines. They are generally employed by some of the wealthy white men, and are paid in provisions and a sort of liquor made from California grapes, called pisco. What money or gold they get for themselves is spent in gambling-a vice to which they are most excessively 
addicted. Instances are not few of their having staked the produce of their labor during some weeks subsequent to the game. Many of the Indians desire no other pay than as much pisco as they can drink, with a little acorn bread.

The native Californians form a goodly proportion of the gold-seekers. Many of the men are accompanied by their wires, who are attended by Indian girls. The graceful Spanish costume of the Californians adds quite a feature to the busy scene at the mines. There may be seen the long, lank forms of the Yankees, with their wide white trouser's and straw hats; the half-naked Indians; the native born Californians, with their dusky visages and lustrous black eyes. The latter are generally clad in a short, tight jacket, with lace trimming, and velvet breeches, with a silk sash fastened round the waist. With regard to the appearance of the women, and, also, for the sake of the description of one of the evening entertainments in the gold region, we quote from a recent tourist, to whom we have been indebted before.*

"The appcarance of the women is graceful and coquettish. Their petticoats, short enough to display in most instances a well-turned ankle, are richly laced and embroidered, and striped and flounced with gaudy colors, of which scarlet seems to have the preference. Their tresses hang in luxiriant plaits down their backs; and in all the little aceessories of dress, such as earrings, necklaces, \&e., the costume is very rich. Its distinguishing feature, lowrever, is the reboso, a sort of scarf, generally made of cotton, which answers to the mantilla of Old Spain. It is

- Four Months Among the Gold Finders of California, by J. Tyr whit Brooks, M. D. 



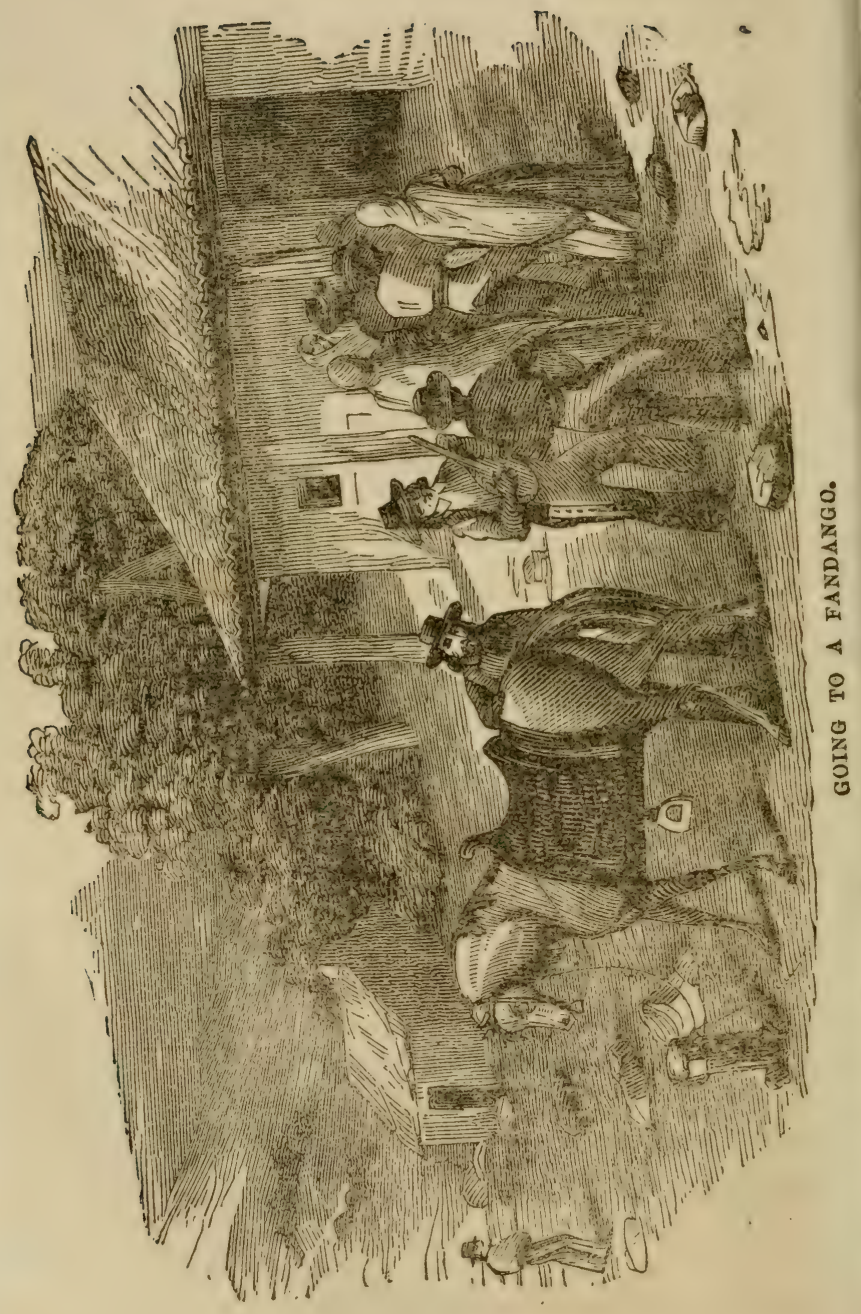


worn in many different and graceful fashions-sometimes twined round the waist and shoulders; at others, hanging in pretty festoons about the figure, but always disposed with that indescribable degree of coquettish grace which Spanish women have been for ages allowed to possess in the management of the fan and the mantilla. Since these arrivals, almost every evening a fandango is got up on the green, before some of the tents. The term fandango, though originally signifying a peculiar kind of dance, seemed to bo used here for an evening's dancing entertainment, in which many different pas are introduced. I was present at a fandango a few nights ago, when a couple of performers were dancing 'el jarabe,' which seemed to consist chiefly of a series of monotonous toe and heel movements on the ground. The motions of the foot were, however, wonderfully rapid, and always in exact time to the music. But at these entertainments the waltz seems to be the standing dish. It is danced with numerous very intricate figures, to which however, all the Californians appear quite au fait. Men and women alike waltz beautifully, with an easy, graceful swinging motion.

"It is quite a treat, after a hard day's work, to go at nightfall to one of these fandangos. The merry notes of the guitar and the violin announce them to all comers; and a motley enough looking crowd, every member of which is puffing away at a cigar, forms an applauding circle around the dancers, who smioke like all the rest. One cannot help being struck by the picturesque costume and graceful movements of the performers, who appear to dance not only with their legs, but with all their hearts and souls. During the interval between the dances, 
coffee is consumed by the senoras, and the coffee with something stronger by the senors; so that, as the night advances, the merriment gets, if not 'fast and furious,' at least animated and imposing."

The dangers which the adventurers are subjected to encounter are often increased by the hostility of the Indians. These, however, only molest those who are daring enough to frequent the outskirts of the gold region. There the Indians are treacherous, and will attack small parties, even after smoking the pipe of peace with them. Their principal weapons are bows and arrows; for though many of them have guns in their possession, the scarcity of ammunition prevents them from using them to any purpose. The following description of an encounter with them by a small party, encamped in the valley of the Bear River, then seldom frequented by white men, will give an idea of their mode of attack :

"We were just on the point of returning to the camp to dinner, when Dowling, who was standing near some sage bushes at the upper part of the ravine, heard a rustling among them, and on moving in the direction of the noise saw an Indian stealthily creeping along, who, as soon as he perceived he was discovered, discharged an arrow, which just missed its mark, but lacerated, and that rather severely, Dowling's ear. The savage immediately set up a most terrific whoop, and ran off, but tumbled before he could draw another arrow from his quiver, while Dowling, rushing forward, buried his mattock in the head of his fallen foe, killing him instantaneously.

"At this moment we heard the crack of a rifle in the direction of the camp, which, with the Indian's whoop at the same moment, completely bewildered us. 
Every man, however, seized his rifle, and Dowling, hastening towards us, told us of what had just occurred. All was still for the next few moments, and I mounted a little hill to reconnoitre. Suddenly I saw a troop of Indians, the foremost of them on horseback, approaching at full speed. I hastily returned to my companions, and we sought shelter in a little dell, determined to await there, and resist the attack, for it was evident that the savages' intentions were any thing but pacific.

"It was a moment of breathless excitement. We heard the tramp, tramp of the horses coming on towards us, but as yet, they and their riders were concealed from our view. I confess I trembled violently, not exactly with fear, although I expected that a few moments would see us all scalped by our savage assailants. It was the suddenness of the danger which startled me, and made my heart throb violently; but at that moment, just as I was reproaching myself with the want of courage, a terrific yell rung through the air at a short distance from us, and forty or fifty warlike Indians appeared in sight. My whole frame was nerved in an instant, and when a shower of arrows flew amongst us, I was the first man to answer it with a rifle-shot, which brought one of the foremost Indians off his horse to the ground. I instantly reloaded, but in the mean while the rifles of my companions had been doing good service. We had taken up our position behind a row of willow trees which skirted the banks of a narrow stream, and here we were protected in a great measure from the arrows of our assailants, which were in most cases turned aside by the branches. A second volley of rifle-shots soon followed the first; and while we were reloading, and the smoke had slightly cleared away, I could see that we had spread 
consternation in the ranks of the Indian warriors, and that they were gathering up their wounded preparatory to retiring. I had my eye on an old man, who had just leaped from his horse. My finger was on the trigger, when I saw him coolly advance, and, taking one of his wounded companions, who had been shot through the leg, in his arms, place him on a horse, then mounting his own, and catching hold of the other animal's bridle, gallop off at full speed. Although I knew full well that if the fortune of the day had gone against us, these savages would not have spared a single man of our party, still I could not find it in my heart to fire on the old chief, and he carried off his wounded comrade in safety.

"In a few minutes the hill-sides were clear, and when we emerged from our shelter, all that was visible of the troop of warriors was three of them weltering in their blood, a bow or two, and some empty quivers, and a fow scattered feathers and tomahawks, lying on the ground."

The grizzly bear is also one of the terrors encountered by the gold-seekers. This animal grows to the size of four feet in height and six in length. It is one of the most ferocious animals of North America. Mules and cattlo of various kinds, and even men, are attacked by it, and its great strength generally enables it to come off with its prey. Great quickness and courage are absolute essentials of those who hunt these animals, or encounter them accidentally. An adventure of two or three gold-seekers, on their road to the mines, accidentally meeting with a grizzly bear, is thus shortly detailed in the journal of a returned adventurer.*

- Six Months in the Gold Mines, by E. Gould Buffum. 
"Ahout half way from the rancheria a loud braying, followed by a fierce growl, attracted our attention, and in a few moments a frightened mule, cluscly pursted by an enormous grizzly bear, deseended the hill-sile within forty yards of where we stood leaning on our rilles. As the bear reached the road, Higgins; with his usual quickness and intrepility, fired, and an mearthly yell from the now infuriated animal told with what effect. The mule in the interval had erossed the roarl, and was now scampering away over the plains, and Bruin, finding himself robber of his prey, turnal unon us. I levelled my rille and gave him the contents with hearty grood will, bit the wounds he had receired only arved to exasperate the nonster, who now made towards us with rapid striles. Deoming prudence the better part of valor, we ran with all convenient speerl in the direction of the camp, within a hundred yards of which my foot becunie entangled in the underbrush, and I fell headlong upon the earth. In another instant I should have fallen a victim to oll Bruin's rage, but a well-directed ball from my companion's rifie entered his brain and arrested his carcer. The whole party now came to our assistance and soon despatched Mr. Grizzly. Dragrging him to camp, we made a hearty supper fiom his fat ribs, and, as I had probably been the more frightened of the two, I claimed as an indemnity his skin, which protected me afterward from the damp ground many a cold night. He was a monstrous feliow, measuring nearly four feet in height, and six in length, and a stroke from lis huge paw would, had he caught us, have entirely dissipated the golden dreams of Higgins and myself.'

The same writer gives quite a graphic description 
of an attack of the scourge of the miners, the disease called scurvy. He says:

"I was again dreaming of fortune and success, when my hopes were blasted by an attack of a terrible scourge that wrought destruction through the northern mines during the winter of 1848. I allude to the land scurvy. The exposed and unaccustomed life of twothirds of the miners, and their entire subsistence upon salt meat, without any mixture of vegetable matter, had produced this disease, which was experienced more or less by one-half of the miners within my knowledge. Its symptoms and progress may not be uninteresting. It was first noticed in the 'Dry Diggings,' where, about the middle of February, many persons were rendered unable to walk by swellings of the lower limbs, and severe pains in them. It was at first supposed to be rheumatism, and was treated as such. But it withstood the most powerful applications used in that complaint, and was finally decided to be scurvy. So long as the circumstances which caused it continued, the disease made rapid progress. Many, who could obtain no vegetables, or vegetable acids, lingered out a miserable existence and died,-while others, fortunate enough to reach the settlements, where potatoes and acids could be procured, recovered. Inoticed its first attack upon myself by swelling and bleeding of the gums, which was followed by a swelling of both legs below the knee, which rendered me unable to walk; and for three weeks I was laid up in my tent, obliged to feed upon the very articles that had caused the disease, and growing daily weaker, without any reasonable prospect of relief. There were, at that time, about eight hundred persons at work on the river, and hoping to get some medicine, I despatched one of 
my companions one morning, with instructions to procure me, if possible, a dose of salts, and to pay for it any price that should be asked. He returned at night with the consoling news that he had failed, having found only two persons who had brought the article with them, and they refused to sell it at any price.

"I was almost in despair; with ouly a blanket between myself and the damp, cold earth, and a thin canvas to protect me from the burning sun by day, and the heavy dews by night, I lay day after day enduring the most intense suffering from pain in my limbs, which were now becoming more swollen, and were turning completely black. Above me rose those formidable hills which I must ascend ere I could ontain relief. I believe I should have died, had not accident discovered the best remerly that could have been jroduced. In the second week of my illness, one of our party, in descending the hill on which he had been deer hunting, found near its base, and strewn along the foot-track, a quantity of beans which sprouted from the ground, and were in leaf. Some one, in descending the hill with a bag of them on his back, had probably dropped them. My companion gathered a quantity and brought them into camp. I had them boiled, and lived entirely on them for several days, at the same time using a decoction of the bark of the spruce tree. These secmed to operate magically; and in a weck after commencing the use of them, I found myself able to walk, -and as soon as my strength was partially restored, I ascended the hill, and with two companions walked into Culoma ; and by living principally upon a regetable diet, which I procured by paying three dollars per pound for potatoes, in a rery short time I recovered." 
Thus life in the gold region is made up of variety and contrast. Sometimes the diggers and washers pass weeks busily engaged at their toilsome occupation, without the monotony of the time and scene being disturbed. Again, adrentures and exciting incidents will be plentiful and rarious. At one time, pleasant weather and fandangos offer easy enjoyment; at another, extremes of weather, hard work, and bad food render the life of the miner almost intolerable. Frequently, the goll-secker chances to meet spots that yield ample reward for his toil; and often lie works bencath the fierce rays of a broiling sun, while his legs are in ehilly water, and his day's toil scarce yielas more than cnough to pay for his living. The trading-posts, situated at and near the mines, do a far more certain and an equally profitable business. They are generally the establishments of shrewd, speculating Yankees, who know what sort of labor is requisite to make a gold-secker suceessful, and prefer to trust to the profits of bargaining in provisions and mining necessaries for gold.

That the country is pregnant with an cnormous quantity of the precious metal is unquestionable. But that severe and weakening labor, together with tough constitutions, are inclispensable refuisites for procuring it, scarcely admits of a doubt. Tery few spend any considerable time in working at the "diggines," who do not suffer from exposure, and lose a portion of their constitutional stability. So far, all attempts at the construction of machines for washing the gold from the sand, have been of little avail. Machines have been invented and carried out to the gold region by some of the numerous companies, which, upon trial, have poon been abandoned for the "cradle," and 


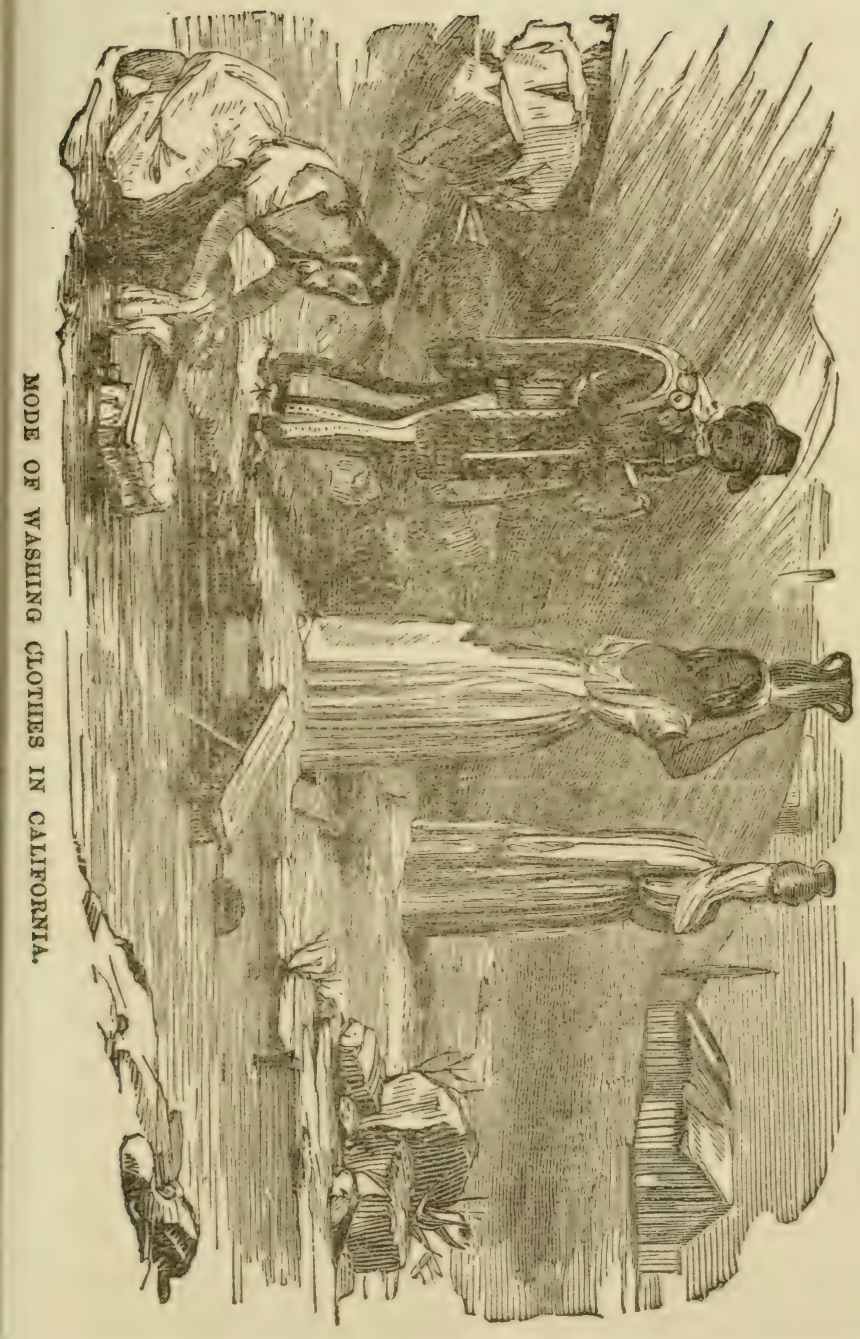



common wash pan; but still, the field for invention is open, and the labor now necessary for procuring the gold is susceptible of considerable diminution. Of course, the means of transporting provisions and other necessaries to the mines are constantly improving, as the country is becoming settled; and thus, one great source of privation and disease is rapidly diminishing.

\section{CHAPTER VIII.}

DESCRIPTION OF SOME OF THE CITIES AND TOWNS OF CALIFORIIA, BEFORE AND AFTER THE DISCOVERY OF THE GOLD MINES.

AT the time of the discovery of the existence of gold in the region of the Sacramento, San Francisco was a very inconsiderable town. As soon as the news of the discovery was spread among its inhabitants, it became almost deserted. Indeed, at one time, there was only seven male inhabitants left in the town. The site of the present city of San Francisco was not then occupied by more than fifty houses in all. These were occupied by a few foreign merchants and some native Californians. The houses were rudely constructed, the principal materials being adobés, or unburnt bricks. They were generally one story high, and most of them were erected near the beach; while at the rear of the "town," was a sandy plain terminated by a range of hills. But as soon as the news of the gold discovery reached the United States, and other countries, companies for mining purposes were imme- 
diately formed, and emigrants soon crowded every route to the "Land of Promise." Then San Francisco began to be the great receptacle of the emigrants and the merchandise of various linds necessary for their maintenance. The following is a rery complete picture of the city after the spreading of the gold news, and the flood of emigration had commeneed.

"Numberless ressels, mostly from the United States, filled the bay, in front of San Francisco, many of them being deserted by their crews, and unalle to procure others to take their places. On landing, I had to clamber up a steep hill, on the top of which, and opposite to where I stood, was a lirge wooden house, two stories high, and scarcely half finished. In the rear of this, rose another and a siecper hill, whose slopes were covered with a multiplicity of tents. To my right, ran a sort of steep, or precipice, defended by sundry pieces of camnon, which commanded the entrance to the harbor. I next came to the 'Point,' and, crossing it, found myself within the town.

"The first objects that attracted my notice were several canvas houses, measuring from ten to forty feet square, some being grog-shops, others eating establishments, and the larger set apart as warehouses, or places of storage. The proprictors of the latter were making enormous sums by the accommodation their tents afforded to the hundreds of travellers who were ariving every day from different parts, and who, being extremely embarrassed as to what they should do with their luggage, were heartily glad to find any safe place to store it in, and content to pay for the convenience.

"The spectacle which the beach presented from a convenient opening, whence I could comprise the 
whole at a glance, was singularly interesting and curious. A crowd of individuals, in motley garb, and of every rariety of race, might be seen pressing eagerly upward towarts the town, jostling and pushing one another, in their anxiety to be first, yet looking eagerly about them, as if to familiarize themselves at once with the country of thoir adoption. IIere were dandies from the United States and from France, picking their steps mincingly, as they strove to keen pace with the sturdy fellows who carried their luggage; their beaver hats, fashionable frock-coats, irreproachable and wellstrapped pantaloons, exoiting the derisive remarks of the spectators, the majority of them 'old Californians,' whose rough labor at the 'diggins' had taught them to estimate such niaiseries at their proper value. By their side stalked the stately and dignifed Spaniard, covered with his broad-brimmed, low-crowned sombrero, and gracefully enreloped in his ample serapa, set off by a bright scarlet, sash. Ile turns neither to the right nor to the left, nor heels the erowd about him, but keeps on the eren tenor of his way-though eren he has occasionally to jump for it-presenting, in his demcanor and costume, a striking contrast to tho more bustling activity of the Yankees, who are elbowing every one, in their anxicty to go a-heal. A lot of shopboys, too-mere lads, as spruce and neatly attired as though they had just stepped out of some fashionable emporium, mingle with the rest, and, as they enter the town, strike up the popular parody-

' Oh, California. That's the land for me!

I'm bound for the Sacramento, with

The wash-bowl on my knee.'

And presently, their brother-adrenturers, exoited 
by hopes of the wildest kind, join vociferously in chorus, in the exuberance of their joy.

"A group of Englisimen, muscular in form, and honest in feature, are chafiering with the keen-witted Tankee porters for the carriage of their luggage. There is an air of dogged resolution about them, that plainly indicates they will not submit to what they evilently consiler an imposition. Such a sum for so slender a service! Well, then, they can carry their baggage themselves: so they will; and, quickly shouldering it, some depart in the track of the rest, whilst two or three remain behind, to watch what is left, until their friends return. They are manifestly well known to one another, and seem to be almost intimate; the royage has made them friends.

"Ilere come a number of Chilians and Peruvians, and a goodly number of natives from the Sandwich Islands. A couple of Irishmen, too! I know them by their vivacity, and by the odd trick they hare of getting into every body's way; to say nothing of their broad, merry faces. 'l'heir property is in common, it seems; for they have only one small pack between them.

"Here come ten or a dozen plainly but comfortably dressed mechanies; hard-working men they seem, and just the sort of persons to make their way in a country where the artisan occupies lis proper position, and where honest toil-and dishonest, too, sometimes-is almost certain to reap a harvest. Far difierently will you fare, and far preferable, too, will be your lot, in regions where priration is the rule, to that of many amongst your numerous fellow-trarellers, unaccustomed as they are to laborious occupations-with frames uninured to fatigue, and constitutions unha- 
bituated to scanty fare, to exposure to heat and cold, and wet and sudlen changes! Whilst you are succeeding in your olject, they will grow wearich, disappointed, and home-sick, and long to bo back again on the theatre of their former struggles.

"The human stream ceases not to flow from the vessels in the harbor; no sooner is one boat-load disposed of than another arrives, and so on, until the town is gorged with new-comers, who, after a few days' sojourn, to recruit their strength, after the fatigues of a long and irksome voyage, depart, and are scen no more for months; many, perhaps, never to return. Very few of this rast multitude deserve the epithet of poor. To get here at all requires money; and to maintain one's self after getting here, the emigrant must have some little means.

"The majority of the emigrants are men occupying a respectable station in society; some are eren distinguished in their calling; but the cager desire of making a fortune in a hurry has induced them to throw up good employments and comfortable homes; to leave friends, rclatires, connexions, wife, children, and familiar associations, to cmbark their strength, intelligence, and activity, in this venture. All is bustle where they have landed: boats going to and fro; rafts slowly discharging their cumbrous loads; porters anxiously and interestedly civil; all excited; ail bent on gain; ships innumcrable in the bry; monntains aroumd; a clear, blue sky abore; and the bright waters dancing in the sun, until they touch the horizon in the distance, blending their brightness with his golden track.

"I walker on wntil I came up to a group of men, who, like myself, were looking on the busy scene 
before us mith no small degree of interest. I recognized amongst them two of the rolunteers, with whom I forthwith claimed acquaintance. The whole party had come from the mines, as was easily to be seen from their appearance, which was something the worse for wear, their countenances being weatherbeaten and bronzed by exposure; whilst their attire, consisting of buckskin coats, leather leggings, and broad-brimmed hats, denoted the sort of labor in which they had been recently engagerl. I learned from them, in the course of a subsequent conversation, that they had all of them been successful at the "diggings.' One of the number lad made, or 'picked,' two thousand dollars, and the rest, from that to nine thousand dollars each, within the space of a few months. With this, however, they were far from satisfied, most of them being determined to realize a large fortune before they quitted the country; for not one of them scemed to have the remotest intention of settling.

"The party had come down from the mines to make purchases, and to enjoy a little recreation. They were admirable specimens of their class-hardy in appearance and rough in demeanor; but shrewd, withal, and toil-enduring. For the moment, their conversation twrned upon the prospects of the newly-landed emigrants - for I should have stated that there were one or two arrivals in the harbor-and they were unsparing of their remarks upon sueh of the now comers as by their dress, or any physical peeuliarity, ofiered a fair tarecet for their witticisms, which were not less pointed than coarse.

"The discovery of the gold mines, has done at once for San Francisco what it was reasonable to 



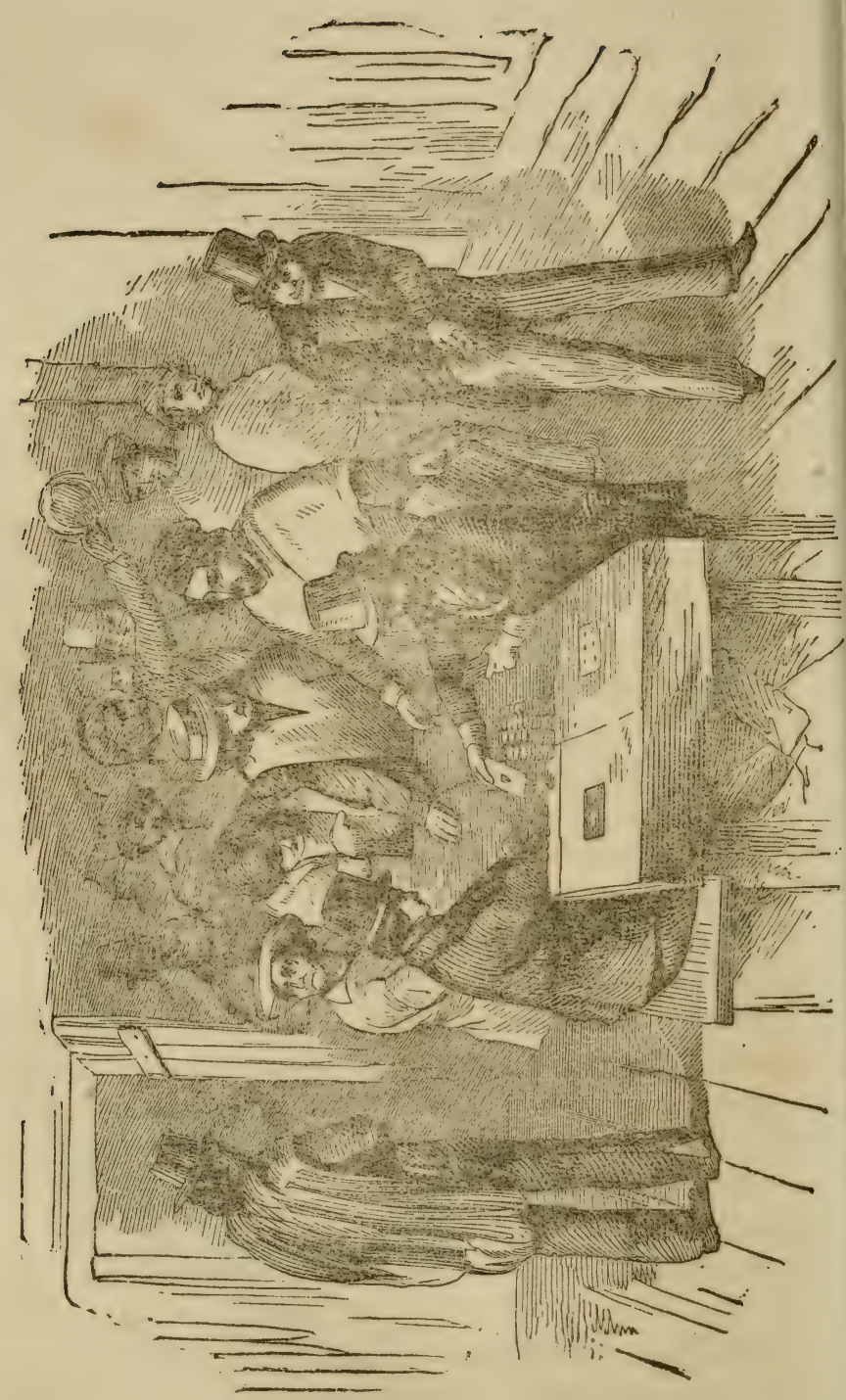


anticipate time only could have effected; and its progress in importance has far outstripped the most sanguine expectations which could be based upon any hypothesis hazarderl on the strength of its admirable position and facilicies for trade. Nevertheless, its growth seems unnatural; and, looking at it as I saw it then, it left on my mind the impression of instability, so marvellous was it to gaze upon a city of tents, wood, and canras, starting up thus suddenly, forming but a halting-place to the thousands who visited it; having for citizens a large majority of gambler's and speculators; and presenting of civilization but the rudest outline, and some of its worst rices. It was impossible, indeed, for an observer to contemplate San Francisco, at this particular period of its history, and not to feel that erery thing about it savored of transition. A storm or a fire must have destroyed the whole in a few hours; for every house, shed, or tent, had manifestly been constructed merely to serve the end of the actual occupier; they were all adapted for trading, but not a convenience or a comfort appertained to them, to indicate a desire or an intention of scttlement. Every day brought new-comers, and added to the number of ephemeral structures which crowded the hill-sides. Alechanics of every description of calling were at work, earnestly, busily, and cheerfully; and, whichever way I turned, there was bustle and activity; jet, withal, I felt that such a state of things was unsound, because resting on what was esscutially speculative, and I doubted not but a great change must come before the city could be regarded as substantially adrancing. Comprised at a glance, it presented no other appearance save that of a confused crowd of tenements, of every variety of construction; some high, some 
low, perched upon the steep hills, or buried in the deep valleys-but still tents and canvas every where and any where, their numbers defying calculation, their structure and position all analysis. There existed neither wells nor ponds within a very considerable distance; and what struck me as most singular, being aware that the Spaniards had a mission here, there was no sign of a church. I subsequently ascertained that the site of the Mission of Dolores, about five miles distant, had been preferred by the Spaniards, and that divine service was performed there still.

"As I proceeded along the road leading into the principal street of the city, I was uncomfortably reminded that it would soon become necessary for me to select a place where I could procure refreshment; and in connexion with this necessity, arose another consideration no less important, namely, where I should lodge? There was no other mode of solving the difficulty, save by an exploration of the localities ; accordingly, I kept these objects in view, whilst I also gratified my curiosity by continuing my perambulations.

"In this same road, but nearer to the entrance of the main street than I should say was, under any circumstances, altogether pleasant, stood the correl of the Washington Market, being a spacious area of ground, inclosed with stakes, over which were stretched raw hides. Owing to the large number of cattle slaughtered here for the use of the inhabitants, the odor from this place was insufferable, and I quickened my pace until my olfactory organs became sensible of a purer atmosphere.

"I turned into the principal street, and soon came up to the market itself, which is a wooden house, about thirty feet square, kept by an American. To my 
right, as I adranced, were some stores and hotels, and a confectioner's shop of remarkably neat and clean appearance: these were all one story, wooden buildings. One of the hotels was appropriately designated as 'The Colonnade.' It was kept by a volunteer named IIuxley, and differed from erery similar establishment in the town, inasmuch as the proprietor allowed neither gambling nor drunkenness on his premises. To this the 'Gotham Saloon,' a little further on, offered a perfect contrast, for here there were several monte rooms and a large bowling-alley, where persons who had a taste for the latter amusement might inilulge in their farorite pastime for a dollar a game. This saloon was likewise kept by two volunteers, as was also the confectioner's by a fourth; so that three of the most moted houses in the town were rented by men, who, a few months before, scarcely possessed any thing sare their enterprise and their industry, but who were now on the high road to opulence. The more credit was due to them, and others of their brethren whom fortune had similarly farored, because, at first, they had deep-rooted prejudices to encounter, which prudence and perseverance only could have enabled them to orercome.

"I came next to the Square, or 'Plaza,' on one side of which, and fronting it, stood the 'Miner's Bank, established by a Mr. Wright, a keen speculator, who had sccured possession of a large extent of landel property, which he was turning to the very best account. On the left of the Plaza, I noticed a spacinns-looking wooden building, two stories high, called the 'Parker House;' but the handsome piazza in front caused me to hesitate on the threshold; for I apprehended-and not without reason-that, even in 
California, appearances must be paid for; as, therefore, my purse was not overstocked, I prudently sought a more modest establishment.

"I passed another hotel, similar to this one, but not quite so large, and came presently to a low wooden house, of most unattractive and unprepossessing exterior, which was dignified by the name of the 'Café Français.' As this seemed likely to suit my present convenience, and to promise a scale of prices on a par with its external appearance, I entered boldly, and seated myself at the dining-table. I noticed, as I went in, that, notwithstanding the poverty without, there was abundance within; the counter being literally overcharged with French pastry, a variety of ingenious culinary preparations, and some foreign liquors.

"After I had finished my repast, consisting of a beef-steak, two eggs, and a couple of cups of coffee, I prepared to depart. I specify the items of which my repast was made up, because of the price I paid for them-namely, two dollars and a half. I was informed, on hazarding an observation respecting the amount, that the charges were excessively moderate, any thing in the shape of a dinner being usually charged one dollar and fifty cents; half a dollar each for the eggs, which were extras, was only a reasonable price for such luxuries, as they frequently sold for double. I considered the information thus obtained to be cheap, of its kind, and went away with a mental reservation not to eat any more eggs in California, unless they were of another description than the golden ones.

" As I repassed the 'Parker House,' the hotel, par excellence, of San Francisco, I went in, knowing that, like all similar establishments, there were the usual amusements going on within. 


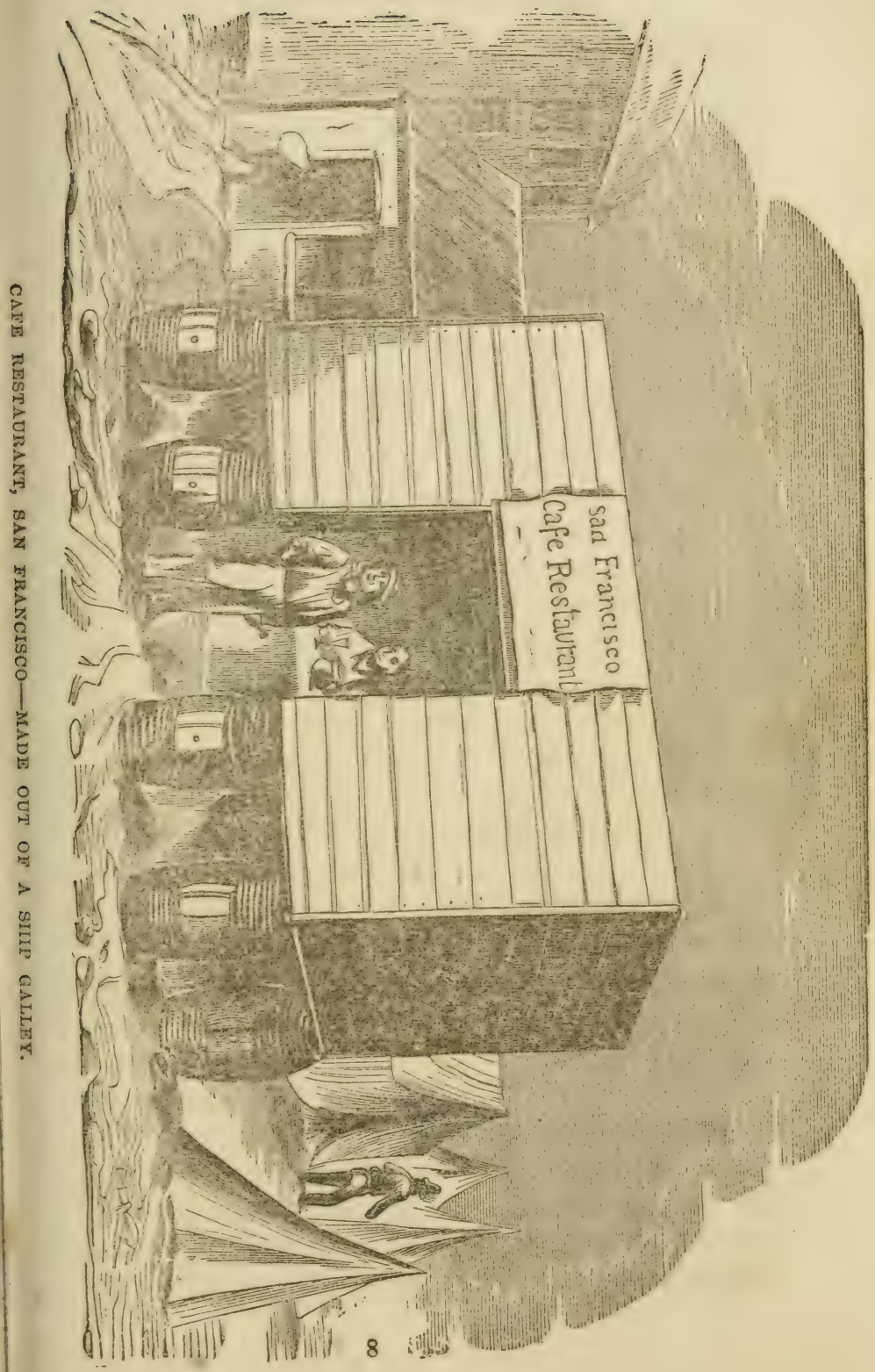



"This is not only the largest, but the handsomest building in San Francisco; and, having been constructed at enormous expense, and entirely on speculation, a concurrence of fortunate circumstances alone, such as had followed upon the discovery of the gold mines, could have insured its prosperity. It was now one of the most frequented, fashionable, and firmly established hotels in the country; and, in so far as it presented a model to the builders and settlers in the town, was a signal illustration of the shrewdness and enterprise of the Iankee character, and a standing credit to the projectors and proprietors.

"It is built entirely of wood, and contains two very spacious principal rooms; the one a dining-room, the other set apart for billiards. Besides these, there are three saloons of lesser dimensions, especially deroted to gambling, and two well supplied bars-one below, to the right of the entry, the other in the billiardroom. The portion of the hotel that is not set apart for the usual offices and conreniences is divided off into innumerable chambers, which are occupied by the superior classes of emigrants-lawyers, doctors, moneybrokers, cum multis aliis.

"The saloon contains two very handsome billiardtables, which are constantly occupied by players, chiefly Americans, some of them of first-rate excellence. The charge was a dollar per game of a hundred, and they were no sooner racated by one party than another came in.

"The establishment contained nine gambling-tables, which were crowded day and night, by the citizens and the miners; many of the latter staking very large sums upon the turn of a card. The stakes, however, varied from twenty-five cents to five thousand dollars; 
and the excitement of some of the losers was frequently fearful to contemplate. Some who gained largely prudently withdrew; and I was informed that, a few days previously to my arrival, a new-comer from the States, who was bound for the mines, having come into the saloon, and tried his fortune at the monte tables, luckily made twenty thousand dollars, with which he returned home, by the steamer, two days afterwards.

"The 'Golden Eagle,' (l'Aguila d' Oro) is another gambling establishment, situated in one of the streets leading into the Plaza. It is a canvas house, about fifty feet square, fitted up with the requisites for play, and let out by the proprietor at the rate of fifteen hundred dollars a month. Every available spot around the tables was crowded to inconvenience by persons who were engaged deeply in the game, the majority standing up and watching the chances with countenances betokening the greatest excitement.

"I now praceeded to the City Hotel, a large but somewhat antiquated building, constructed of adobé, after the Spanish fashion, but hybridized by American improvements. The interior was eren more insufferable than the El Dorado, in respect of the boisterousness of its frequenters. In the first room that I entered were five gambling-tables, doing a 6 smashing business'-a term employed, somewhat in contradiction to its import, to denote prosperity. The majority of the players were Americans and other foreigners, intermixed with a goodly number of Spaniards of the lowest order. There was the same excitement, the same recklessness, and the same trickery here, as at the other gambling saloons, only infinitely more noise and smoke, and swearing and inebriety. 
"Here I met with another of the volunteers, who proposing a walk, we went out together, and proceeded to the Plaza. I found a good many old acquaintances set up in business at this spot; one, who had been a captain, had recently turned money-broker, and now kept an office for the exchange of coin and gold-dust, haring entered into partnership with a highly respectable and agreeable indiridual, of actire business habits, who promised to prove a great acquisition to the concern.

"We soon reached a low, long, aclolé building, situated at the upper side of the square, and which my companion told me was the Custom Ilouse. To the right of the Plaza stood the Saint Charles's Hotel, a wooden edifice covered in with canvas, and the Peytona House, an establishment of a similar description, in both of which we did not fail to find the usual games carried on.

"The streets lcading down to the water-side contain comparatively few hotels or eating-houses, they being chiefly rood and canvas trading-stores. I observed amongst them several newly opened auction and commission-rooms, where goods were being put up, recommended and knocked down in true Yankee style. An immense number of wooden frame-houses in course of erection met our view in every direction; and upon remarking that many of them appeared to have been purposely left incomplete, I ascertained that this arose from the extreme difficulty of procuring lumber, which, on account of its scarcity, occasionally fetched an incredibly high price. A good deal of it is brought from Oregon, and some from South America. Many of the larger houses, but far inferior, notwithstanding, to such of the same kind as could easily be procured 
in New York at a rental of from 300 to 400 dollars a-year, cost here at least 10,000 dollars to build them, the lots on which they were erected being valued at sums varying from 30,000 to 50,000 dollars, according to the locality. Many spots of ground, just large enough for a small trading-house or a tent to stand upon, let at from 1200 to 2000 dollars.

"Amongst the various emigrants who daily flocked into the city-for each day brought its fresh arrivals -were numerous Chinese, and a rery considerable number of Frenchmen, from the Sandwhich Islands and from South America. The former had been consigned, with houses and merchandise, to certain Americans in San Francisco, to whom they were bound by contract, as laborers, to work at a scale of wages very far below the average paid to mechanics and others generally. The houses they brought with them from China, and which they set up where they were wanted, were infinitely superior and more substantial than those erected by the Yankees, being built chiefly of logs of wood, or scantling, from six to eight inches in thickness, placed one on the top of the other, to form the front, rear, and sicles; whilst the roofs were constructed on an equally simple and ingenious plan, and were remarkable for durability.

"These Chinese had all the air of men likely to prove good citizens, being quiet, inoffensive, and particularly industrious. I once went into an eatinghouse, kept by one of these people, and was astonished at the neat arrangement and cleanliness of the place, the excellence of the table, and moderate charges. It was styled the 'Canton Restaurant;' and so thoroughly Chinese was it in its appointments, and in the manner of service, that one might have easily fancied one's 
self in the heart of the Celestial Empire. The barkeeper-though he spoke excellent English-was a Chinese, as were also the attendants. Every article that was sold, even of the most trifling kind, was set down, in Chinese characters, as it was disposed of; it being the duty of one of the waiters to attend to this department. This he did very cleverly and quickly, having a sheet of paper for the purpose, on which the article and the price were noted down in Chinese characters, by means of a long, thin brush, moistened in a solution of Indian or Chinese ink. As I had always been given to understand that these people were of dirty habits, I feel it only right to state that I was delighted with the cleanliness of this place, and am gratified to be able to bear testimony to the injustice of such a sweeping assertion.

"As for the French, they scemed entirely out of their element in this Yankee town; and this circumstance is not to be wondered at, when the climate and the habits of the people are taken into consideration, and also the strange deficiencies they must have observed in the ordinary intercourse of life between the citizens, so different from the polished address, common even amongst the peasantry in their rudest villages; to say nothing of the dificulty of carrying on business amongst a people whose language they did not understand. But their universal goal was the mines; and to the mines they went, with very few exceptions.

"Speaking of them reminds me of a 'Café Restaurant,' in San Francisco, kept by a very civil Frenchman, and situated on the way to the Point. I mention it, because I one day made here $i_{i}$ ' most uncomfortable repast it had ever been my lot tu it down to. 
Yet this was not owing to any lack of attention on the part of the proprietor, to any inferiority in the quality of his provisions, or to any deficiency of culinary skill in their preparation; but simply to the prevalence of the pest to which $I$ have already alluded as inrading my own tent, namely, the dust. The house was buit chiefly of wood, and had a canvas roof, but this was insufficient to keep out the impalpalle particles with which the air was charged, and which settled upon and insinuated themselves into erery article in the place. There was dust on the counter, on the shclves, on the seats, on the decanters, and in them; on the tables, in the salt, on my beef-steak, and in my coffce. There was dust on the polite landlord's cheeks, and in his amiable wife's eyes, which she was wiping with the corner of a dusty apron. I hurried iny meal, and was paying my score, when I caught sight of my own face in a dusty-looking and dust-corered glass near the bar, and saw that I too had become corered with it, my cntire person being literally enerusted with a coat of powder, from which I experienced considerable difficulty in cleansing myself.

"Notwithstanding all I had seen of San Francisco, there yet existed here a world apart, that I should never have dreamed of, but for my being one day called upon to act upon a jury appointed to sit in inquest over a person who had died there. This place was called the 'Happy Valley.'

"Previously to our repairing thither, we attended at the court-house, to take the usual oath. Procecding then through the lower part of the town, we reached the beach, along which, by the water-side, we walked for a distance of three miles-up to our ancles in mud and sand-until we came to a spot where there 
were innumerable tents pitched, of all sizes, forms, and descriptions, forming an irregular line stretching along the shore for about two miles.

"The ground was, of course, low, damp, and muldy; and the most unmistalieable eridences of discomfort, misery, and sickness, met our view on erery side, for the locality was one of the unwholesomest in the vicinity of the town. Iet here, to aroid the payment of enormous ground-rents, and at the same time to combine the advantage of cheap living, were encamper the major portion of the most recently arriver cmigrants, and, amongst the rest, those of the ship Brooklyn, on one of the passengers of which the inquest was about to be held.

"This, then, was the 'Hanny Valley;' a term no donbt applied to it in derision, taking into consideration the squalur, the discomfort, the filth, the misery, and the distress that were rife there.

"I am satisfied that much of the crime and lawlessness that is preralent in California-particularly in towns like San Francisco, where the ruder sex are congregated exclusively and in large multitudes-is attributable to the want of the humanizing presence of women. In San Francisco there were about ten thousand males, and scarcely a hundred females ; for, although in many parts of California the latter outnumber the former, the national prejudice against color was ton strong for legitimate amalgamation to take place."

Such was San Francisco soon after the discovery of the riches of the Sacramento region. From an insignificant settlement, sometimes the resort of whaling-ressels, and of a few traders, it was quickly transferred into a city, with an cxtensire and con- 
stantly increasing commerce. In its streets and squares, erected where, just before, was a desert plain, people of almost every nation were seen busily engaged in traffic, or preparing for departure to the gold region. It seemed the work of the enchanter.

Although, like San Francisco, Honterey was almost deserted by its inhabitants upon the receipt of information of the gold discovery, it soon began to give signs of improvement. The bay, upon the shore of which the town is located, is more exposed to the swell of the sea, and to the north-west storms, than the Bay of San Francisco, and therefore the harbor is inferior. Yet Monterey received a considerable share of the tide of emigration. Those who stopped there were generally persons who intended to make a permanent settlement, and engage in mercantile pursuits; and, therefore, though the increase of the town was not so rapid as that of San Francisco, it carried with it more denotements of stability.

The town is situated on a short bend near the entrance of the bay, upon its southern side. The point of land which partly protects its harbor from the sea is called Point Pinos. A very neat and pretty appearance is presented by the houses of the native Californians, which are generally constructed of actovés and white-plastered. Those of the Americans are easily distinguished by their being built of logs and planks, and presenting a more substantial, but rougher appearance. The town is surrounded by hills, covered with lofty pine trees. Upon a height which overlooks the town and harbor, a fort was built by the Americans during the war with Mexico, and a military force continued there till after the treaty of peace.

The country in the neighborhood of Monterey is 
fertile, and yields ample reward to the agriculturist. There would, therefore, be no lack of supplies of provisions, but for the indolence of the Californians, owning the different ranches in the surrounding country. From this eause, great scareity of provisions of all kinds is often the result. Notwithstanding the additions made by Yankee enterprise and innovation, the general manners and customs of the inhabitants of Monterey retain all their old Spanish character; and some of the customs of the natives, particularly their amusements, are heartily joined in by the more susceptible of the new-comers. The fandango and the serenade with the guitar, still hold their sway as freely and as undisturbed as in old Spain. The winters are severely felt here. The rain causes torrents of water to pour down from the hills in the rear of the town, deluging the principal streets, and rendering their passage almost impossible. During this period, the only resort of the inhabitants for passing away the time is the vice of gambling, in which they early become adepts. This gambling propensity, noticed among the Californians, induced a considerable number of the initiated to emigrate from the United States, and Monterey received a goodly proportion of them. Such an increase of the population, however, could not be considered desirable. Upon the whole, though in a less degree, the effect of the golden attractions of California could be seen at Monterey as at San Francisco. Though it did not spring at once from a small settlement to a large city, it was considerably improved, and in 1849, it numbered more than a thousand inhabitants.

A short distance south of Monterey, is the town of Santa Barbara. Its situation is one of the most 
beautiful in California. It is built upon a plain ten miles in extent. In front is a broad bay, haring a smooth beach of nearly thirty miles in extent. On the right, towards the water, is a lofty eminence rising nearly a thousand feet. Directly back of the town is a range of almost impassable hills, running in a diagonal direction. There is no harbor in the bay, and vessels are obliged to anchor in an open roadstead; and when the south-east winds prevail, they are in constant peril.

The progress of the town was not much affected by the gold mania. But though it offers no attractions for mercantile or gold digging purposes, it has others which will, no doubt, make it a favorite place of resi'dence. In 1849, it contained about one hundred and fifty houses, built of adolies, and all one story in height. The town is celebrated for being the residence of the aristocracy of California, and for its beautiful women. Its inhabitants are principally rancheros, who visit their ranches two or three times in a ycar to see to the marking and killing of their cattle, and then spend the remainder of the year in the town, enjoying life as much as possible. Indolence is the general vice. A horse to ride, plenty to eat, and cigaros to smoke constitute their summum bonum. Santa Barbara is more celebrated for its fandangos than any other town on the coast. These are open to all comers, and constitute the general pastime of an evening. The climate is mild and spring-like, and, independent of the attractions in the town, the surrounding country offers many of the most beautiful rides in California. About a mile in the rear of the town, at the top of a gentle slope, is the mission of Santa Barbara, with its old, white walls and cross-mounted 
spires. The presiding priest of California resides there, and a number of the converted Indians still remain and cultirate the surrounding soil. The mission is in a better condition than any other in the country.

Ciudad de los Angeles, or the City of the Angels, is eituated a hundred and ten miles south of Santa Bailsara, at the end of an immense plain, extending from the city twenty-five miles, to San Pedro, its port. This is the garden spot of Califomia. Before the discovery of the gold mines, the City of the Angels was the largest town in the country. It contains about tw thousand inhabitants, most of whom are wealthy runcheros, who dwell there to cultirate the grape. As in all the towns of California, the houses are constructed of adobes and corered with asphaltum, which is found in great quantities near the town. The northern section is lail out in streets, and is occupied by the trading citizens; the southern section is made up of gardens, rinyards and orchards, which are made extremely productire by irrigating the soil with the water of a large stream running through them. Many acres of ground are coverch with rines, which, being trimmed every year, are kept about six feet in heigit. In the fall of the year, these vines are burdened with rich clusters of grapes; and, in addition to these, great quantities of fruit of rarious kinds are raised. The surrounding country abounds with game of all linds. In the rainy scason, millions of ducks and gecse corcr the plains between Los Anceles and sur Iulio, while the neichboring hills abound with givitis, dior, elk, and antelope. The rimeyards protice such quantities of grapes, that many thousand baxcls of wine and aguardiente-the lrandy of the country- 
are annually manufactured. The wine is of various kinds; some of it being equal to the best produced in Europe.

The inhabitants of the City of the Angels, being generally of the wealthy class of Californians, have always strongly adhered to the institutions of Mexico. They offered the most strenuous resistance to the American forces at the time of the conquest of California, but were vanquished in two battles, and the city taken. All the customs and amusements peculiar to the Spaniards and the countries which they colonized, are here in full vogue. Music, dancing, singing, slaughtering cattle, or gambling, are the usual pastimes of the inhabitants. Yet, with these trifling occupations, attachment to the Roman Catholic church and a careful observance of its ceremonies, is characteristic of all. Upon the tolling of the bell, gaming, swearing, dancing-every thing is stopped while the prescribed prayer is muttered, and then all go on as before.

Though Los Angeles did not experience any increase of population consequent upon the flood of emigration to California, its delightful climate and its fertile soil are gradually procuring it such consideration as will doubtless lead to the filling up of the surrounding country.

San Diego is the most southern town of Upper California. It is situated on the coast, three miles north of the line separating Upper and Lower California. The harbor is inferior only to that of San Francisco. It is perfectly sheltered by land from the gales at all seasons of the year. Vessels can lie within a cable's length of the beach, there being no surf running upon it. The town is situated about three miles 
from the beach, and is about the same size as Santa Barbara, It is a place of far greater facilities and promise, however, than the last mentioned town. San Diego has always been the most important depot for hides, upon the coast; and there is no doubt that an extensive inland trade will be carried on between it and the towns in the interior, as the region of the Colorado and the Gila becomes settled. Since the conquest of Upper California and the discovery of the gold, the progress of the town has been rapid. From being an inconsiderable settlement sustained principally by a mission, which had early been established there, it has become a town of great commercia. promise. The climate being mild and pleasant, and the surrounding country abounding in game and adapted for grazing, thus making provisions abundant, San Diego is a very desirable place of residence.

The town of San José is situated in a fertile valley, near the most southern extremity of the Bay of San Francisco. On the south of the town runs a small stream, and the place is surrounded by plains, affording fine pasturage. Being situated on the direct route from the southern ports to the gold mines, San José received a considerable stimulus from their discovery. A profitable trade was soon established, and the town improved rery rapidly. It is now a town of about four thousand inhabitants, and the increase still continues rapid. In a greater degree than any of the older towns of California, it has all the eridence of a thriving and progressive place. The greater part of the buildings are constructed in a style which shows the inroads of the taste of the people from the Atlantic States. A number of Mormons settled here at an early period, and built a great many neat wooden 
houses and cottages, which contrast farorably with the heary old adotés residences of the native inhabitants. Flour and saw-mills have been erected, but the scarcity of water is sererely felt by their proprietors.

San José in respect to climate and general abundance of the necessaries and luxuries of life, is one of the most desirable places of residence in California. Though situated a short distance inland, and thus denived of the facilities which contributed to the rapid growth of San Francisco, the fertile plain.surrounding it, and the increase of the inland trade and trayel will draw to the town and its neighborhood a thriving, business population. The old mission of San José is situated about ten miles from the town. The establishment and the grounds belonging to it are in a state of decay. The population there is about three lumdred in number, most of whom are Indians, and all of them in a degraded condition.

The emigration to the gold region caused many towns to spring up, as if by magic, in its neighborhood, and on the route to it from San Francisco. These were principally the stopping places of the golcl-seekers, or the seat of a trade in provisions and articles manufactured in the States and transported thither. Some of these towns have become of a size sufficient to. warrant the assertion that they will soon rival the cities of the Atlantic coast of the United States. The progress of these places is aided by the enormous price of real estate in San Francisco.

One of the most promising of the new towns is called Benicia. It is situnted on the Strait of Carquinez, thirty-fire miles north of San Francisco. The strait forms the entrance of Suisan into Pablo Bay. The 
site of Benicia is a gentle slope, which, descending to the water, becomes almost a plain. Tessels of the first class can lie at anchor at its bank, and discharge their cargoes, and the harbor is safe from violent winds. The town has been made the head-quarters of the Pacific division of the United States army, and a site for a nary-yard has been selected by Commodore Jones. The marks of governmental favor show in what estimation the position of Benicia is held. The town was laid out in 1848, by Robert Semple and Thomas 0 . Larkin. Early in 1850 , lots were selling at very high rates, and the population numbered more than a thousand persons.

Between Benicia and Sacramento city, several towns have been laid out, all in very favorable positions. The principal are-Martinez, on the southern shore of the strait of Carquinez, nearly opposite Benicia; New York of the Pacific, at the junction of the River San Joaquin with the Bay of Suisan; Suisan, on the west bank of the Sacramento, at a distance of eighty miles from San Francisco.

Next to San Francisco, Sacramento is the largest city in California. It is situated on the eastern bank of the Sacramento River, one hundred miles from San Francisco, and sixty-five from Suisan Bay. It is located on a beautiful plain, which is not elevated more than ten or twelve feet above the river at low water. Whis being insufficient to protect it from the rise of the waters of the river, several disastrous floods have occurred during the existence of the city. Up to this point, the river is narigable for large class steamers. ships drawing not more than twelve feet of water may go up that far at all seasons; and, besides these commercial advantages, Sacramento is the natural 
trading depot for the richest portion of the mining regions.

Where the city of Sacramento now stands, at the time of the gold discovery, there stood, "sulitary and alone," a small fort. This formed the nucleus, about which, at the commoncement of the rush of emigration, the town soon sprang into existence. Its increase - has been almost as rapid as that of San Francisco. During the rainy season of the early part of 1850 , the population numbered somewhere between twenty and thirty thousand. But at that poriod, a considerable portion of the gold-diggers made Sacramento and the other towns in the neighborhood of the mines, their resort, to escape the severity of spending the season at the open and exposed valleys of the gold region. The city is regularly laid out, but its appearance eridences the rapidity of its erection. The greater number of the houses and stores in the neighborhood of the river are constructed of wood, while the outskirts, particularly upon the south, are oceupicd by the tents of the constantly-amiving overland enigrants. Before the commencement of the last rainy season, the number of these emigrants reached two or three thousand. They squatted uron the vacant lots which had been surveyed and sold to other persons. This caused a considerable agitation in the town, which continued till the disastrous flood swept both the parties off the gromul, and thus lifi the field clcar for another commencement. Siarramento is the grand receptacle of the orerland cmigration, and this, combined with its commercill facilities, will continue to give the city a superiority over the majority of the other places in California.

Adjoining Sacramento city, is the town of Sutter. 


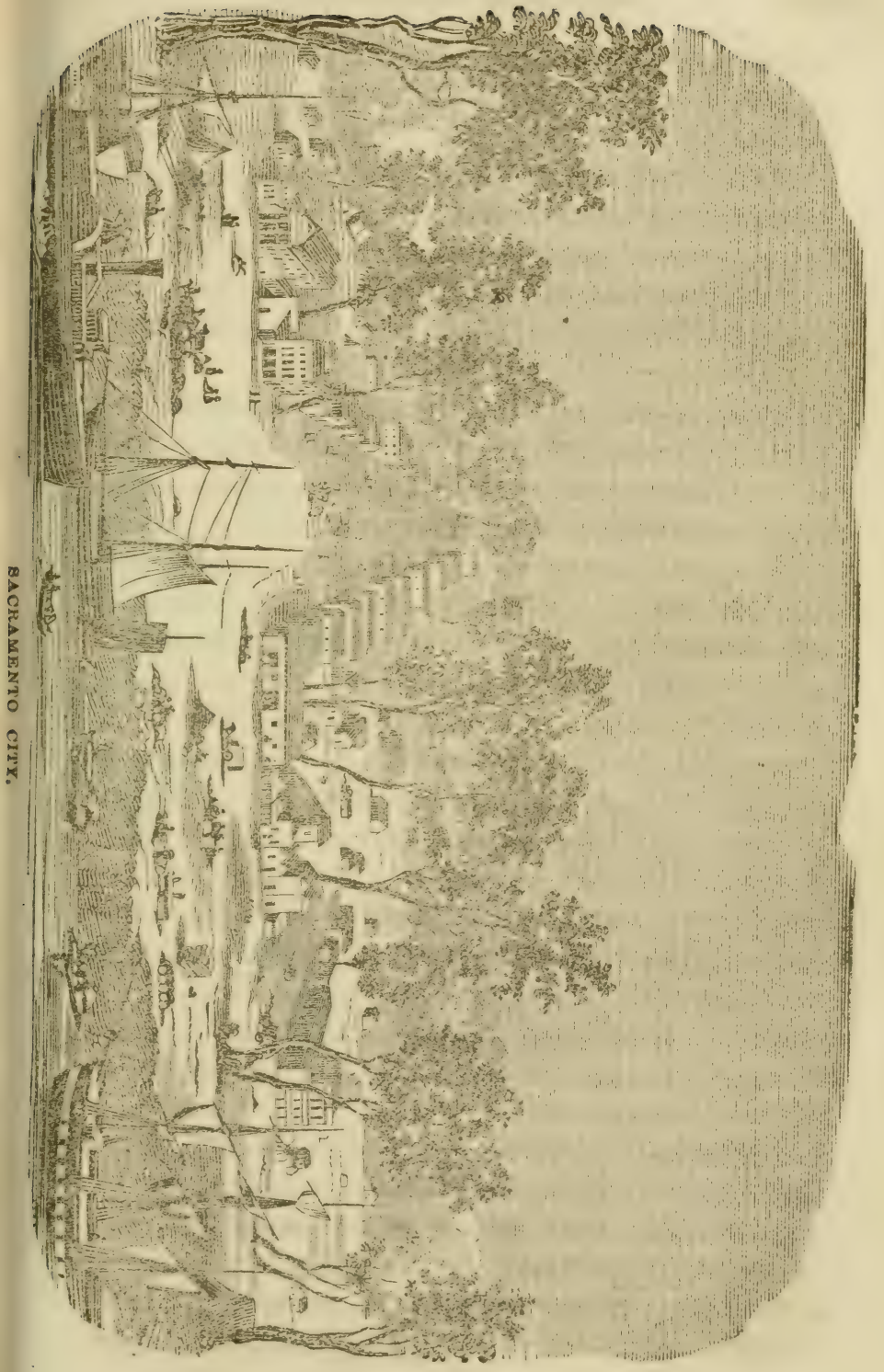



It is situated on the highest and healthiest ground on the river. It is not, like Sacramento, subject to an annual overlow. The town was originally laid out by Captain Sutter and others; and is owned by Hon. John McDougall, Lieutenant-Governor of California, and Captain Sutter. It has a thriving business population, and its position, and the fertility of the neighboring country will soon make it a place of importance.

Stockton is to the southern portion of the gold region what Sacramento is to the northern. It is situated upon a slough, or a succession of sloughs, containing the back waters formed by the junction of the San Joaquin and Sacramento Rivers. It is about fifty miles from the mouth of the San Joaquin, and one hundred from San Francisco. The ground upon which it is situated is high and is not subject to overflow. Vessels drawing nine feet water can ascend the San Joaquin as far as Stockton, and discharge their cargoes on the bank. In the latter part of 1848 , the town was laid out and a frame building erected by Charles M. Weber. In eight months from that time, it contained a population of about two thousand permanent residents, and a large number of temporary residents, on their road to the mines. Communication is with San Francisco by means of steamboats and launches, and the commerce of the town is constantly increasing.

Other towns exist-on paper-in the neighborhood of San Francisco and the gold region, and, doubtless, they will, in the course of time, become settled by a thriving, go-ahead population from the Atlantic States. Land speculation in California is as profitable a business as gold-digging-and less toilsome. Many of 
the shrewd ones, who early took advantage of this "tide in the affairs of men," have already reached the goal of their hopes, an independent fortune. Those who saw how things would turn out, and purchased land in the neighborhood of the region which promised to receive the principal current of the emigration to California, found themselves wealthy in the short space of a few months.

The great influx of emigrants to Upper California has brought the subject of the settlement of the peninsula into consideration. There is but little doubt that Lower California will, sooner or later, become the property of the United States, and then its settlement and progress will be rapid. The coast upon the gulf affords many excellent harbors, and the mountainous region of the interior gives abundant evidence of mineral wealth, as far as it has been explored. Several silver mines have been opened in different places, the principal of which are at San Antonio, between $\mathrm{La}_{\mathrm{a}}$ Paz and Cape San Lucas. Near Loretto, the first settlement in California, extensive copper mines have been opened, and lead and iron abound in all directions. The pearl fishery of the gulf has already yielded an enormous wealth, having been prosecuted from the time of the discovery of the peninsula. The fishing season lasts from May till November, and more than a hundred vessels are yearly engaged in the business. These resources, despite the general unfitness of the country for a gricultural purposes, will soon attract their full share of consideration, and cause an influx of emigrants and adventurers from the United States and other countries. Some portions of the country are susceptible of irrigation, and might thus be rendered fit for cultivation. 
The principal port of Lower California is $\mathrm{La} \mathrm{Paz}$, situaterl near the mouth of the gulf. The bay on the shore of which the town is located, is of great extent and heanty, and possesses a large number of rich pearl oyster-beils-the pearl fishery having at one time supplied the chief article of traffic on this part of the coast. The country around the bay is elerated and picturesque, though rugged; the soil being composed principally of rock and sand, wildly and irregularly corered with the most prickly species of stunter bushes and shrubs of sunburnt hue. The town of La Paz is neatly built and presents a pretty appoarance. The streets are lined with willow trees, and these meeting overhead, form a delicious shade during the heat of the day. The houses are all constructed of adubés, plastered white, and thatched with the leures of the palm tree. The beach is lined with palms, cocoa-nut, fig and tamarind trees. La Paz was taken by the American rolunteers during the war with Mexico, and considerable destruction of the orchnels, gardens and houses of the town was the conneruence. The harbor offers great advantages for a naral station, and such, doubtless, it will become.

fan Jose, the most southern town of Lower California, is sitnaterl alout half-way between Cape San Lucas and Cape Palmo, on a sort of desert plain, extmuling from the beatiful ralley of San Jose to the cereat. It is lowated about three miles from the beach, aul is one of the stmangest ereations in the shape of a town imaginable.

The heary rains and freshets which occur in the wet :en:on, in this region, render every elevation inralutble as a preservative against the dangers of sudren immdations; hence all the houses are built upon 
steeps, rocks, and hillocks, necessarily irrespective of order; so that, even in the most densely populated districts, barren hills, as yet unoccupied by dwellings, are frequently to be met with, with deep hollows in every part, converting mere visits into positive enterprises, in most instances both tedious and disagreeable. To these great natural disadvantages, the indolence of the inhabitants has added others, their common practice being to dig for adobé clay at the nearest convenient spot, namely, for the most part, opposite their own doors; thus, one would imagine that the site of the whole town had been visited and disturbed by a succession of miniature earthquakes, which, whilst they had left the houses themselves unshaken, had heaved and perched them up in the most uncomfortable positions, and in the most inaccessible places. In the very centre of the principal street, which appears to have once upon a time been level, are three or four immense clay-pits, serving as a receptacle for dead dogs, cats, bones, vegetable refuse, and, in a word, every description of rubbish and nuisance a very dirty population can convey to or discharge in them.

But a description of the town would be incomplete without adding that it is dotted about in these hollows, and in the sand-holes in the rocks, with patches of thorn, brush, and cacti, forming a singular yet refreshing contrast with the general barrenness of the region itself, the whole being surrounded by a bleak mountainous range, which increases in elevation until it blends with the clear sky, far in the distance.

The principal, indeed the only regular street in the town, is wide and long, the houses being constructed of adobés and cane, thatched with palm leaves. It is blocked up at the remoter end by the fort, which 

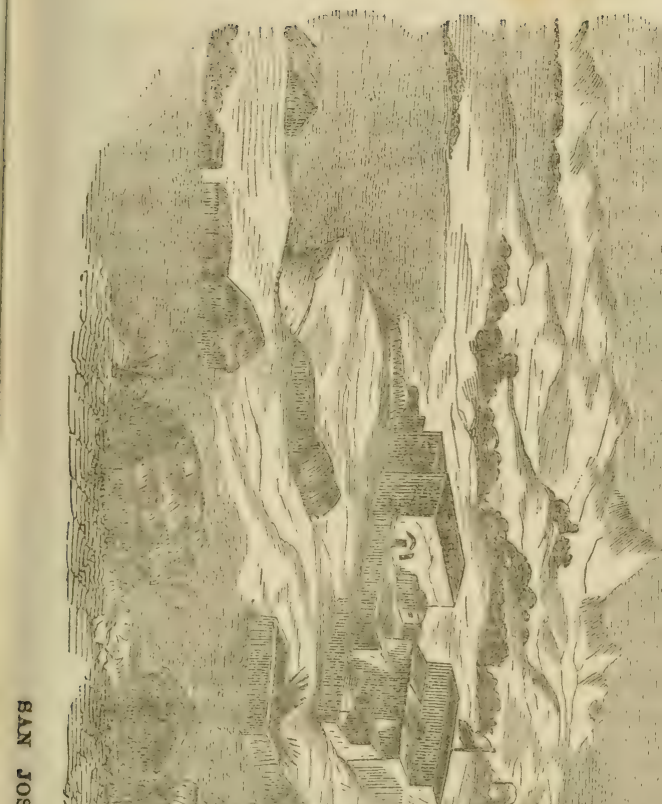

-1
0

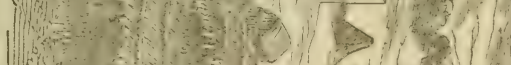

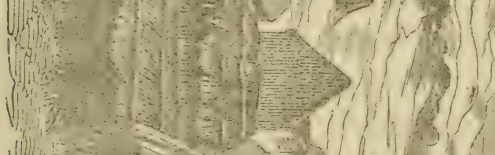

1(i) $1+\cdots+1$

|

$10+1$

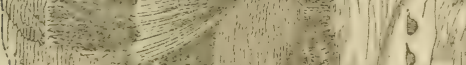

(n)

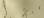



stands upon a wide foundation of rock of considerable elevation; various portions of the adobé walls connecting the crags having been pierced, so as to allow artillery to be trained through the embrasures, whilst, in other parts, there are numerous loop-holes for musketry. There are some very awkward cavities amongst these rocks, produced by digging for clay for the adobé work. The fort is flat-roofed and parapetted, having portholes for cannon; and below, in the very centre of the building, occupying about a third of its entire length, runs a thick wall, forming a crescent, well mounted with heary guns. At the end of this crescent, between it and the front wall, is the entrance to the fort-a mere aperture, barely wide enough to allow of one man's passing in.

These defences proved to be of great advantage to a small party of Americans that landed at San José, during the war between the United States and Mexico, and were compelled to take shelter in the old quartel, or barracks. There they were surrounded by the Californians, and stood a siege of several weeks', suffering incredible hardships. The population of San José numbers about three thousand, the majority being semi-Indians, or the pure descendants of the Mexicans. There is little promise of any considerable increase in the size of the town, owing to the natural disadvantages of situation.

The other towns of Lower California are-San Antonio, in the neighborhood of an extensive silver mine, which has been worked for a long time with considerable profit; Loreto, on the gulf coast, about two hundred miles north of La Paz; San Domingo and Todos Santos, on the Pacific coast. The latter town is situated on the bay of the same name, and is 
the most northerly part of Lower California. The church and mission buildings at this place are the largest and most imposing structures of the kind in Lower California. The church has a handsome front and a lofty steeple. The mission is the residence of the head of the church in Lower California. There is every reason to believe, that, when the richer portions of Upper California begin to get a little crowded, the tide of emigration will be turned to the south, and the ports of the peninsula will become of great commercial importance. Then, if not before, the country will become the property of the United States, either by way of purchase, or after the manner of Texas.

\section{CHAPTER IX.}

THE FORMATION OF A STATE GOVERNMENT.

THe state of things which induced the people of California to form a state government deserves to be fully set forth. Their condition was without precedent in history ; and from a statement of that condition, it will be seen that the framing of a constitution and the organization of a state government was the only resource of the Californians. The representations of the report of Thomas Butler King to the gorernment of the United States will not be cuntradicted, and these we insert.

"The discovery of the gold mines had attracted a very large number of citizens of the United States to 
to that territory, who had never been accustomed to any other than American law, administered by American courts. There they found their rights of property and person subject to the uncertain, and frequently most oppressive, operation of laws written in a language they did not understand, and founded on principles, in many respects, new to them. They complained that the alcaldes, or judges, most of whom had been appointed or elected before the inmigration had commenced, were not lawyer's by education or profession; and, being Americans, they were, of course, unacquainted with the laws of Mexico, or the principles of the civil law on which they are founded.

"As our own laws, except for the collection of revenue, the transmission of the mails, and establishment of postoflices, had not been extended over that territory, the laws of Mexico, as they existed at the conclusion of the treaty of Guadalupe Hidalgo, regulating the relations of the inhabitants of California with each other, necessarily remained in force; ${ }^{*}$ yet, there was not a single volume containing those laws, as far as I know or believe, in the whole territory, except, perhaps, in the governor's office at Monterey. - "The magistrates, therefore, could not procure them, and the administration of justice was, necessarily, as unequal and fluctuating as the opinions of the judges were conflicting and variable.

"There were no fee-bills to regulate costs; and, consequently, the most cruel exactions, in many instances, were practised.

"The greatest confusion prevailed respecting titles to property, and the decision of suits involving the

- See American Insurance Company, et al. vs. Canter, 1st Peters' Supreme Court Reports, 542. 
most important rights, and very large sums of money depended upon the dictum of the judge.

"The sale of the territory by Mexico to the United States had necessarily cut off or dissolved the laws regulating the granting or procuring titles to land; and, as our own land-laws had not been extended over it, the people were compelled to receive such titles as were offered to them, without the means of ascertaining whether they were valid or not.

"Litigation was so expensive and precarious that injustice and oppression were frequently endured, rather than resort to so uncertain a remedy.

"Towns and cities were springing into existence; many of them without charters or any legal right to organize municipal authorities, or to tax property or the citizens for the establishment of a police, the erection of prisons, or providing any of those means for the protection of life and property which are so necessary in all civil communities, and especially among a people mostly strangers to each other.

"Nearly one million and a half of dollars had been paid into the custom-house, as duties on imported goods, before our revenue laws had been extended over the country; and the people complained bitterly that they were thus heavily taxed without being provided with a government for their protection, or laws which they could understand, or allowed the right to be represented in the councils of the nation.

"While anxiously waiting the action of Congress, oppressed and embarrassed by this state of affairs, and feeling the pressing necessity of applying such remedies as were in their power, and circumstances seemed to justify, they resolved to substitute laws of their own 
for the existing system, and to establish tribunals for their proper and faithful administration.

"In obedience, therefore, to the extraordinary exigencies of their condition, the people of the city of San Francisco elected members to form a legislature, and clothed them with full powers to pass laws.

"The communities of Sonoma and of Sacramento city followed the example.

"Thus were three legislative bodies organized; the two most distant being only one hundred and thirty miles apart.

"Other movements of the kind were threatened, and doubtless would have followed, in other sections of the territory, had they not been arrested by the formation of a State government.

"While the people of California were looking to Congress for a territorial government, it was quite evident that such an organization was daily becoming less suited to their condition, which was entirely different from that of any of the territories out of which the new States of the Union had been formed.

"Those territories had been at first slowly and sparsely peopled by a few hunters and farmers, who penetrated the wilderness, or traversed the prairies, in search of game or a new home; and, when thus gradually their population warranted it, a government was provided for them. They, however, had no foreign commerce, nor any thing beyond the ordinary pursuits of agriculture, and the various branches of business which usually accompany it, to induce immigration within their borders. Several years were required to give them sufficient population and wealth to place them in a condition to require, or enable them to support, a State government. 
"Not so with California. The discorery of the vast metallic and mineral wealth in her mountains had already attracted to her, in the space of twelve months, more than one hundred thousand people. An extensive commerce had sprung uip with China, the ports of Niexico on the Pacific, Chili, and Australia.

"Hundreds of ressels from the Atlantic ports of the Union, freighted with our manufactures and agricultural products, and filled with our fellow-citizens, had arrived, or were on their passage round Cape Horn ; so that, in the month of June last, (1819) there were more than three hundred sea-going ressels in the port of San Francisco.

"California has a border on the Pacifie of ten degrees of latitude, and several important harbors which have never been surveyed; nor is there a buoy, a beacon, a lighthouse, or a fortification, on the whole coast.

"There are no docks for the repair of national or mercantile vessels nearer than New York, a distance of some twenty thousand miles round Cape IIorn.

"All these things, together with the proper regulations for the gold region, the quicksilver mines, the survey and disposition of the public lands, the adjustment of land titles, the establishment of a mint and of marine hospitals, required the immediate formation of a more perfect civil gorernment than California then had, and the fostering care of Congress and the Executive.

"California had, as it were by magic, become a State of great wealth and power. One short year had given her a commercial importance lut little inferior to that of the most powerful of the old States. She had passed her minority at a single bound, and 
might justly be regarded as fully entitled to take her place as an equal among her sisters of the Union.

"When, therefore, the reality became known to the people of that territory that the government had done nothing to relieve them from the evils and embarrassments under which they were suffering, and seeing no probalility of any change on the subject which divided Congless, they adopted, with most mexampled unanimity and promptitude, the only course which lay open to them-the immediate formation of a State government.

"They were induceil to take this step not only for tha reason that it promised the most speedy remedy for present dificulties, but because the great and rapidly growing interests of the territory demanded it; and all refiecting men saw, at a glance, that it onght not to be any longer, and could not, under any circumstances, be much longer postponed.

"They not only considered themselres best qualified, but that they had the right to decide, as far as they were concerned, the embarrassing question which was shaking the Union to its centre, and had thus far deprived them of a regularly organized civil government. They beliered that, in forming a constitution, they had a right to establish or prohibit slavery, and that, in their action as a State, they would be sustained by the North and the South.

"In taking this step, they proceeded with all the regularity which has ever characterized the American people in discharging the great and important duties of self-government.

"The steamer in which I was a passenger did not stop at Monterey; I therefore did not see General Riley, nor had I any communication with him until 
about the middle of the month, when he came to San Francisco. A few days after my arrival, his proclamation calling a Convention to form a State constitution, dated the third of June, was received.

"The people acted in compliance with what they believed to be the riews of Congress, and conformably to the recommendations of the proclamation; and proceeded, on the day appointed, to elect members to a Convention for the purpose of forming a constitution, to be regularly submitted to the people for their ratification or rejection, and, if approved, to be presented to Congress, with a prayer for the almission of California, as a State, into the Union."

According to the recommendation of General Riley, the civil governor of California, an election of delegates to form a Convention was held on the 1st of August, 1849. The number of delegates to be elected was thirty-seven. General Riley, General Smith, and Thomas Butler King, used every means to stimulate the people to hold the preparatory meetings, and they were generally successful. But in some districts scarcely any move was made until a few days before the election. In one or two instances, the election was not held upon the day appointed; but the Convention nevertheless admitted the delegates elected in such cases.

The Convention was to meet on the 1st of September, at Monterey; but it did not get regularly organized until the 4th of that month, when Dr. Robert Semple, of the Sonoma district, was chosen president. The proportion of the native Californian members to the American was about equal to that of the population. Among the members was Captain John Sutter, the pioneer settler of California, General Valleja and 
Antonio Pico, who had both been distinguished men in California, before the conquest. The body, as a whole, commanded respect, as being dignified ard intellectual.

The Declaration of Rights was the first measure adopted by the Convention. Its sections being general and liberal in their character, were nearly all adopted by a unanimous rote. The clause prohibiting the existence of slavery was the unanimous sentiment of the Convention. The Constitution will be found in another part of this work, and we will not here recapitulate its provisions. It combines the best features of the Constitutions of the States east of the Rocky Mountains, and is in most respects similar to that of the State of New York.

The most exciting questions discussed were, a clause prohibiting the entrance of free people of color into the State, the boundary line, and the great seal of the State. The first, the clause prohibiting the entrance of free people of color into the State, passed first reading, but was subsequently rejected by a large majority. The question of suffrage occasioned some discussion, widely differing opinions being entertained by the members. An article was adopted by the Convention, excluding Indians and negroes, with their descendants, from the privilege of voting; but it was subsequently modified by a proviso, which gave the Legislature power of admitting Indians, or the descendants of Indians to the right of suffrage by a two-thirds concurrent vote. Under this provision, some of the most wealthy and influential Californians are excluded from voting until permitted by the Legislature.

The boundary question, which came up towards the 
close of the Convention, was the most exciting theme. The point of dispute was the eastern boundary line. The Pacific formed the natural boundary on the west; the parallel of 42 degrees, the boundary on the north, and the Mexican line, run in conformity with the treaty of Guadalupe Hidalgo, the boundary on the south. The discussion, reconsideration and voting upon the various propositions occupied nearly two days. Finally, the line detailed in the Constitution ras adopted.

The discussion upon the adoption of the Great Seal for the State was amusing. Eight or ten designs were offered, and the mernbers from the different districts were all anxious to have their particular district represented. The choice finally fell upon one offered by a Major Garnett. The principal figure is Minerva, with spear and shield, emblematic of the manner in which California was born, full-grown, into the confederacy. At her feet crouches the grizzly bear. Before him is the wheat-sheaf and vine, illustrating the agricultural products of the country. Near them is the miner, with his implements. In the distance is the Bay of San Francisco, and beyond that, the Sierra Nevada, over which appears the word "Eureka." The closing scenes of the Convention are described in graphic and vivid colors by one who was an eye-witness to them, and recorded them upon the spot.*

"The members met this morning at the usual hour, to perform the last duty that remained to them-that of signing the Constitution. They were all in the happiest humor, and the morning was so bright and balmy that no one seemed disposed to call an organi-

- Bayard Taylor, El Dorado, or Adventures in the Path of Empire. 
zation. Mr. Semple was sick, and Mr. Steuart, of San Francisco, therefore called the meeting to order by moring Captain Sutter's appointment in his place. The chair was taken by the old pioneer, and the members took their seats around the sides of the hall, which still retained the pine-trees and banners, left from last night's decorations. The windows and doors were open, and a delightful breeze came in from the bay, whose blue waters sparkled in the distance. The view from the balcony in front was bright and inspiring. The town below-the shipping in the harbor-the pine-covered hills behind-were mellowed by the blue October haze, but there was no cloud in the sky, and I could plainly see, on the northern horizon, the mountains of Santa Cruz and the Sierra de Gavilan.

"After the minutes had been read, the Committee appointed to draw up an Address to the people of California, was called upon to report, and Mr. Steuart, Chairman, read the Address. Its tone and sentiment met with universal approval, and it was adopted without a dissenting roice. A resolution was then offered to pay Lieutenant Hamilton, who is now engaged in engrossing the Constitution upon parchment, the sum of $\$ 500$ for his labor. This magnificent price, probably the highest ever paid for a similar service, is on a par with all things else in California. As this was their last session, the members were not disposed to find fault with it, especially when it was stated by one of them that Lieutenant Hamilton had written day and night to have it ready, and was still working upon it, though with a lame and swollen hand. The sheet for the signer's names was ready, and the Convention decided to adjourn for half an hour and then meet for the purpose of signing. 
"I amused myself during the interval by walking about the town. Every body knew that the Convention was about closing, and it was generally understood that Captain Burton had loaded the guns at the fort, and would fire a salute of thirty-one guns at the proper moment. The citizens, therefore, as well as the members, were in an excited mood. Monterey never before looked so bright, so happy, so full of pleasant expectation.

"About one o'clock the Convention met again; few of the members, indeed, had left the hall. Mr. Semple, though in feeble health, called them to order, and, after having voted General Riley a salary of $\$ 10,000$, and Mr. Halleck, Secretary of State, $\$ 6000$ a year, from the commencement of their respective offices, they proceeded to affix their names to the completed Constitution. At this moment a signal was given; the American colors ran up the flag-staff in front of the government buildings, and streamed out on the air. A second afterward the first gun boomed from the fort, and its stirring echoes came back from one hill after another, till they were lost in the distance.

"All the native enthusiasm of Captain Sutter's Swiss blood was aroused; he was the old soldier again. He sprang from his seat, and, waving his hand around his head, as if swinging a sword, exclaimed; 'Gentlemen, this is the happiest day of my life. It makes me glad to hear those cannon: they remind me of the time when I was a soldier. Yes, I am glad to hear them-this is a great day for California!' Then, recollecting himself, he sat down, the tears streaming from his eyes. The members with one accord, gave three tumultuous cheers, which were heard from one end of the town to the other, As the signing went 
on, gun followed gun from the fort, the echoes reverberating grandly around the bay, till finally, as the loud ring of the thirty-first was heard, there was a shout: 'That's for California!' and every one joined in giving three times three for the new star added to our Confederation.

"There was one handsome act I must not omit to mention. The captain of the English bark Volunteer, of Sidney, Australia, lying in the harbor, sent on shore in the morning for an American flag. When the first gun was heard, a line of colors ran fluttering up to the spars, the stars and stripes flying triumphantly from the main-top. The compliment was the more marked, as some of the American ressels neglected to give any token of recognition to the event of the day.

"The Constitution having been signed and the Convention dissolved, the members proceeded in a body to the house of General Riley. The risit was evidently unexpected by the old veteran. When he made his appearance, Captain Sutter stepped forward, and having shaken him by the hand, drew himself into an erect attitude, raised one hand to his breast as if he were making a report to his commanding officer on the field of battle, and addressed him as follows:

"Gereral: I have been appointed by the delegates, elected by the people of California to form a Constitution, to address you in their names and in behalf of the whole people of California, and express the thanks of the Convention for the aid and coöperation they have received from you in the discharge of the responsible duty of creating a State government. And, sir, the Convention, as you will perceive from the official records, duly appreciates the great and important services you have rendered to our common 
country, and especially to the people of California, and entertains the confident belief that you will receive from the whole of the people of the United States, when you retire from your official duties here, that verdict so grateful to the heart of the patriot: 'Well done, thou good and faithful servant.'

"General Riley was visibly affected by this mark of respect, no less appropriate than well deserved on his part. The tears in his eyes, and the plain, blunt sincerity of his voice and manner, went to the heart of every one present. 'Gentlemen,' he said, 'I never made a speech in my life. I am a soldier-but I can feel; and I do feel deeply the honor you have this day conferred upon me. Gentlemen, this is a prouder day to me than that on which my soldiers cheered me on the field of Contreras. I thank you all from my heart. I am satisfied now that the people have done right in selecting delegates to frame a Constitution. They have chosen a body of men upon whom our country may look with pride; you have framed a Constitution worthy of California. And I have no fear for California while her people choose their representatives so wisely. Gentlemen, I congratulate you upon the successful conclusion of your arduous labors; and I wish you all happiness and prosperity.'

"The General was here interrupted with three hearty cheers which the members gave him, as Governor of California, followed by three more, ' as a gallant soldier, and worthy of his country's glory.' He then concluded in the following words: 'I have but one thing to add, gentlemen, and that is, that my success in the affairs of California is mainly owing to the efficient aid rendered me by Captain Halleck, the Secretary 


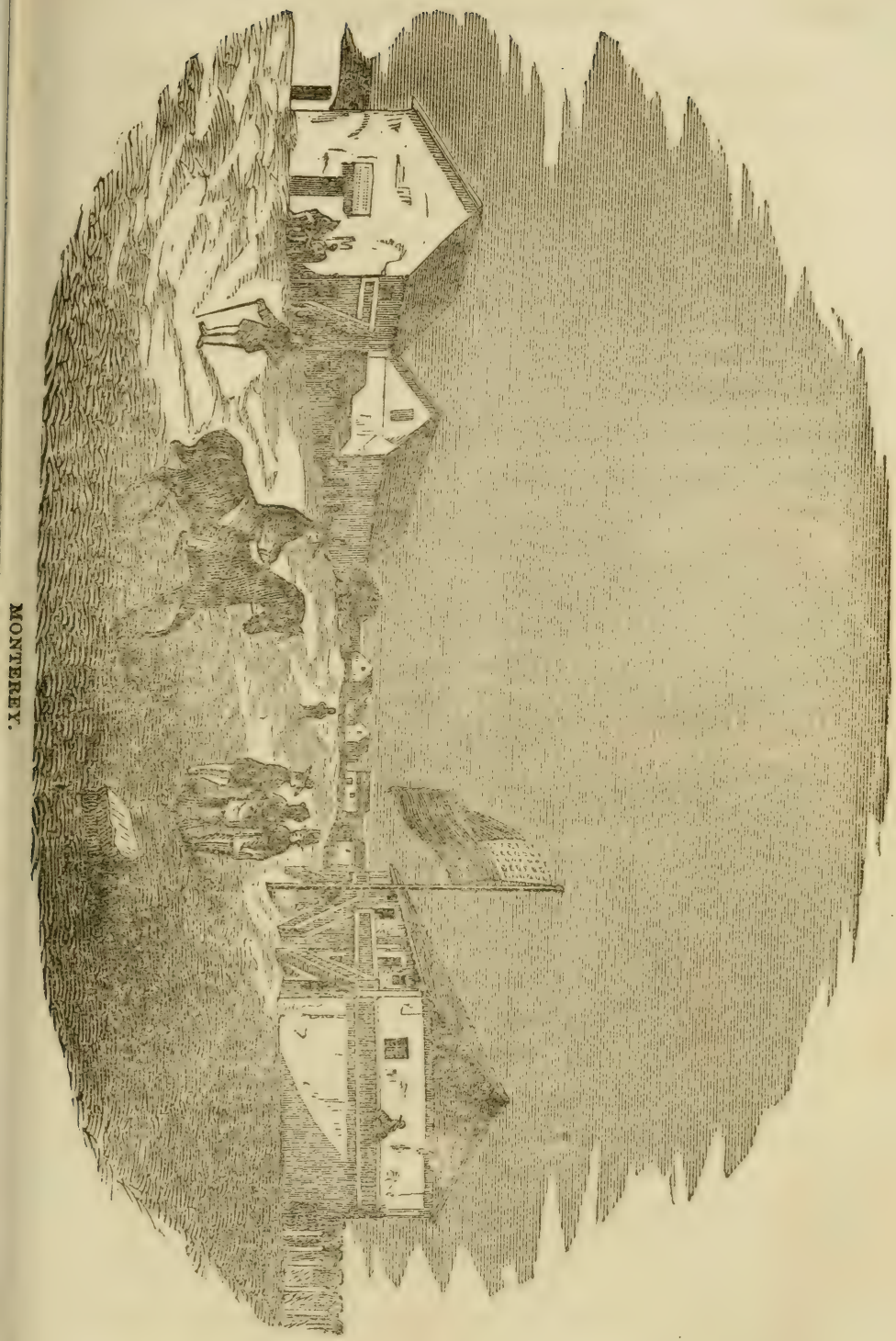



of State. He has stood by me in all emergencies. To him I have always appealed when at a loss myself; and he has never failed me.'

"This recognition of Captain Halleck's talents and the signal service he has rendered to our authorities here, since the conquest, was peculiarly just and appropriate. It was so felt by the members, and they responded with equal warmth of feeling by giving three enthusiastic cheers for the Secretary of State. They then took their leave, many of them being anxious to start this afternoon for their various places of residence. All were in a happy and satisfied mood, and none less so than the native members. Pedrorena declared that this was the most fortunate day in the history of California. Even Carillo, in the beginning one of our most zealous opponents, displayed a genuine zeal for the Constitution, which he helped to frame under the laws of our republic."

The elections for the various officers under the new Constitution took place on the 13th of November, 1849. Peter H. Burnett was chosen Governor, and John McDougall, Lieutenant-Governor. George W. Wright and Edward Gilbert were chosen to fill the posts of representatives in Congress. The first State Legislature met at the capital, the pueblo de San Jose, on the 15th of December, and elected John C. Fremont and Wm. M. Gwin, Senators to Congress. Every branch of the ciril government went at once into operation, and admission into the Union as a State seems all that is necessary to complete the settiement of affairs in California. 


\section{CHAPTER X.}

population, Climate, productions, \&c.

WITH regard to the population, climate, soil, productions, \&c., we extract from Mr. King's Report, as giving the most reliable and complete information.

"Humboldt, in his 'Essay on New Spain,' states the population of Upper California, in 1802, to have consisted of

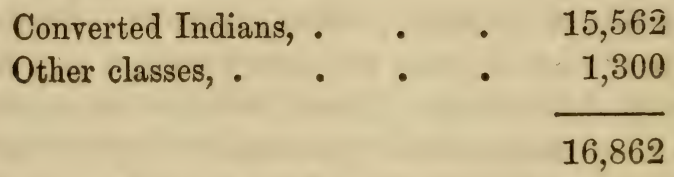

"Alexander Forbes, in his 'History of Upper and Lower California,' published in London, in 1839, states the number of converted Indians in the former to have been, in 1831, . . . 18,683 Of all other classes, at . . . 4,342

23,025

" $\mathrm{He}$ expresses the opinion that this number had not varied much up to 1885 , and the probability is, there was very little increase in the white population until the emigrants from the United States began to enter the country in 1838.

"They increased from year to year, so that, in 1846, Colonel Fremont had little difficulty in calling to his standard some five hundred fighting men.

"At the close of the war with Mexico, it was supposed that there were, including discharged volunteers, 
from ten to fifteen thousand Americans and Californians, exclusive of converted Indians, in the territory. The immigration of American citizens in 1849, up to the 1st of January last, was estimated at eighty thousand-of foreigners, twenty thousand.

"The population of California may, therefore, be safely set down at 115,000 at the commencement of the present year.

"It is quite impossible to form any thing like an accurate estimate of the number of Indians in the territory. Since the commencement of the war, and especially since the discovery of gold in the mountains, their numbers at the missions, and in the valleys near the coast, have very much diminished. In fact, the whole race seems to be rapidly disappearing.

"The remains of a vast number of villages in all the valleys of the Sierra Nevada, and among the foothills of that range of mountains, show that at no distant day there must have been a numerous population, where there is not now an Indian to be seen. There are a few still retained in the service of the old Californians, but these do not amount to more than a few thousand in the whole territory. It is said there are large numbers of them in the mountains and valleys about the head-waters of the San Joaquin, along the western base of the Sierra, and in the northern part of the territory, and that they are hostile. A number of Americans were killed by them during the last summer, in attempting to penetrate high up the rivers in search of gold; they also drove one or two parties from Trinity River. They have, in several instances, attacked parties coming from or returning to Oregon, in the section of country which the lamented Captain Warner was examining when he was killed. 
"It is quite impossible to form any estimate of the number of these mountain Indians. Some suppose there are as many as three hundred thousand in the territory, but I should not be inclined to believe that there can be one-third of that number. It is quite evident that they are hostile, and that they ought to be chastised for the murders already committed.

"The small bands with whom I met, scattered through the lower portions of the foot-hills of the Sierra, and in the valleys between them and the coast, seemed to be almost the lowest grade of human beings. They live chiefly on acorns, roots, insects, and the kernel of the pine burr; occasionally, they catch fish and game. They use the bow and arrow, but are said to be too lazy and effeminate to make successful hunters. They do not appear to have the slightest inclination to cultivate the soil, nor do they even attempt it-as far as I could obtain information-except when they are induced to enter the service of the white inhabitants. They have never pretended to hold any interest in the soil, nor have they been treated by the Spanish or American immigrants as possessing any.

"The Mexican government never treated with them for the purchase of land, or the relinquishment of any claim to it whatever. They are lazy, idle to the last degree, and, although they are said to be willing to give their services to any one who will provide them with blankets, beef, and bread, it is with much diffculty they can be made to perform labor enough to reward their employers for these very limited means of comfort.

"Formerly, at the missions, those who were brought up and instructed by the priests made very good servants. Many of these now attached to families seem 
to be faithful and intelligent. But those who are at all in a wild and uncultivated state are most degraded objects of filth and idleness.

"It is possible that government might, by collecting" them together, teach them, in some degree, the arts and habits of civilization; but, if we may judge of the future from the past, they will disappear from the face of the earth as the settlements of the whites extend over the country. A very considerable military force will be necessary, however, to protect the emigrants in the northern and southern portions of the territory."

So much for the population of California at the commencoment of the present year, (1850.) By its close, it is highly probable, the number will reach two hundred thousand, exclusive of the Indians. Such a population, composed, for the most part, of those who are impregnated with the active, progressive spirit of the American people, will undoubtedly conduct California to a brilliant position among the stars of the republic. With regard to the climate of the country, various conflicting statements have been promulgated, which arises from the visits of those who make the statements having been made to different portions of the country, and stating the climate of a portion as the climate of the whole. Mr. King's Report furnishes the most accurate account of the changes of the temperature, and the state of the atmosphere throughout the year, together with an explanation of their causes. He says-

"I come now to consider the climate. The climate of California is so remarkable in its periodical changes, and for the long continuance of the wet and dry seasons, dividing, as they do, the year into about two two equal parts, which have a most peculiar influence 
on the labor applied to agriculture and the products of the soil, and, in fact, connect themselves so inseparably with all the interests of the country, that I deem it proper briefly to mention the causes which produce these changes, and which, it will be seen, as this report proceeds, must exercise a controlling influence on the commercial prosperity and resources of the country.

"It is a well-established theory, that the currents of air under which the earth passes in its diurnal revolutions, follow the line of the sun's greatest attrac. tion. These currents of air are drawn towards this line from great distances on each side of it; and, as the earth revolves from west to east, they blow from. north-east and south-east, meeting, and, of course, causing a calm, on the line.

"Thus, when the sun is directly, in common parlance, aver the equator, in the month of March, these currents of air blow from some distance north of the Tropic of Cancer, and south of the Tropic of Capricorn, in an oblique direction towards this line of the sun's greatest attraction, and forming what are known as the north-east and south-east trade winds.

"As the earth, in its path round the sun, gradually brings the line of attraction north, in summer, these currents of air are carried with it; so that about the middle of May the current from the north-east has extended as far as the 38th or 39th degree of north latitude, and by the twentieth of June, the period of the sun's greatest northern inclination, to the northern portions of California and the southern section of Oregon.

"These north-east winds, in their progress across the continent, towards the Pacific Ocean, pass over the snow-capped ridges of the Rocky Mountains and 
the Sierra Nevada, and are, of course, deprived of all the moisture which can be extracted from them by the low temperature of those regions of eternal snow, and consequently no moisture can be precipitated from them, in the form of dew or rain, in a higher temperature than that to which they have been subjected. They, therefore, pass over the hills and plains of California, where the temperature is very high in summer, in a very dry state; and, so far from being charged with moisture, they absorb, like a sponge, all that the atmosphere and surface of the earth can yield, until both become, apparently, perfectly dry.

"This process commences, as I hare said, when the line of the sun's greatest attraction comes north in summer, bringing with it these rast atmospheric morements, and, on their approach, produce the dry season in California ; which, governed by these laws, continues until some time after the sun repasses the Equator in Septembes, when, about the middle of November, the climate being relieved from these northeast currents of air, the south-west winds set in from the ocean charged with moisture-the rains commence and continue to fall, not constantly, as some persons have represented, but with sufficient frequency to designate the period of their continuance, from about the middle of November until the middle of May, in the latitude of San Francisco, as the vet season.

"It follows, as a matter of course, that the dry season commences first, and continues longest in the southern portions of the territory, and that the climate of the northern part is influenced in a much less degree, by the causes which I have mentioned, than any other section of the country. Consequently, we find that, as low down as latitude $39^{\circ}$, rains are suff- 
ciently frequent in summer to render irrigation quite unnecessary to the perfect maturity of any crop which is suited to the soil and climate.

"There is an extensive ocean current of cold water, which comes from the northern regions of the Pacific, or, perhaps, from the Arctic, and flows along the coast of California. It comes charged with, and emits in its progress, cold air, which appears in the form of fog when it comes in contact with a higher temperature on the American coast, as the gulf-stream of the Atlantic exhales vapor when it meets, in any part of its progress, a lower temperature. This current has not been surveyed, and, therefore, its source, temperature, velocity, width, and course, have not been accurately ascertained.

"It is believed, by Lieutenant Maury, on what he considers sufficient evidence-and no higher authority can be cited-that this current comes from the coasts of China and Japan, flows northwardly to the peninsula of Kamtschatka, and, making a circuit to the eastward, strikes the American coast in about latitude $41^{\circ}$ or $42^{\circ}$. It passes thence southwardly, and finally loses itself in the tropics.

"Below latitude thirty-nine, and west of the foothills of the Sierra Nevada, the forests of California are limited to some scattering groves of oak in the valleys and along the borders of the streams, and of red wood on the ridges and in the gorges of the hills - sometimes extending into the plains. Some of the hills are covered with dwarf shrubs, which may be used as fuel. With these exceptions, the whole territory presents a surface without trees or shrubbery. It is covered, however, with various species of grass, and, for many miles from the coast, with 
wild oats, which, in the valleys, grow most luxuriantly. These grasses and oats mature and ripen early in the dry season, and soon cease to protect the soil from the scorching rays of the sun. As the summer advances, the moisture in the atmosphere and the earth, to a considerable aepth, soon becomes exhausted; and the radiation of heat, from the extensive naked plains and hill-sides, is very great.

"The cold, dry currents of air from the north-east, after passing the Rocky Mountains and the Sierra Nevada, descend to the Pacific, and absorb the moisture of the atmosphere, to a great distance from the land. The cold air from the mountains, and that which accompanies the great ocean current from the north-west, thus become united; and vast banks of fog are generated, which, when driven by the wind, has a penetrating, or cutting, effect on the human skin, much more uncomfortabie than would be felt in the humid atmosphere of the Atlantic, at a much lower temperature.

"As the sun rises from day to day, week after week, and month after month, in unclouded brightness during the dry season, and pours down its unbroken rays on the dry, unprotected surface of the country, the heat becomes so much greater inland than it is on the ocean, that an under-current of cold air, bringing the fog with it, rushes over the coast range of hills, and through their numerous passes, towards the interior.

"Every day, as the heat, inland, attains a sufficient temperature, the cold, dry wind from the ocean commences to blow. This is usually from eleven to one $o$ 'clock; and, as the day advances, the wind increases and continues to blow till late at night. When the vacuum is filled, or the equilibrium of the atmosphere 
restored, the wind ceases; a perfect calm prevails until about the same hour the following day, when the same process commences and progresses as before; and these phenomena are of daily occurrence, with few exceptions, throughout the dry season.

"These cold winds and fogs render the climate at San Francisco, and all along the coast of California, except the extreme southern portion of it, probably more uncomfortable, to those not accustomed to it, in summer than in winter.

"A few miles inland, where the heat of the sun modifies and softens the wind from the ocean, the climate is moderate and delightful. The heat, in the middle of the day, is not so great as to retard labor or render exercise in the open air uncomfortable. The nights are cool and pleasant. This description of climate prevails in all the valleys along the coast range, and extends throughout the country, north and south, as far eastward as the valley of the Sacramento and San Joaquin. In this vast plain, the sea-breeze loses its influence, and the degree of heat in the middle of the day, during the summer months, is much greater than is known on the Atlantic coast in the same latitudes. It is dry, however, and probably not more oppressive. On the foot-hills of the Sierra Nevada, and especially in the deep ravines of the streams, the thermometer frequently ranges from $110^{\circ}$ to $115^{\circ}$ in the shade, during three or four hours of the day, say from eleven until three o'clock. In the evening, as the sun declines, the radiation of heat ceases. The cool, dry atmosphere from the mountains spreads over the whole country, and renders the nights cool and invigorating.

"I have been kindly furnished, by Surgeon-General 
Lawson, U. S. Army, with thermometrical observations, taken at the following places in California, viz : At San Francisco, by Assistant-Surgeon W. C. Parker, for six months, embracing the last quarter of 1847 and the first quarter of 1848 . The monthly mean temperature was as follows: October, $57^{\circ}$; Norember, $49^{\circ}$; December, $50^{\circ}$; January, $49^{\circ}$; February, $50^{\circ}$; March, $51^{\circ}$.

“At Monterey, in latitude $36^{\circ} 38^{\prime}$ north and longitude $121^{\circ}$ west, on the coast, about one degree and a half south of San Francisco, by Assistant-Surgeon W. S. King, for seven months, from May to November inclusive. The monthly mean temperature was: May, $56^{\circ}$; June, $59^{\circ}$; July, $62^{\circ}$; August, $59^{\circ}$; September, $58^{\circ}$; October, $60^{\circ}$; November, $56^{\circ}$.

"At Los Angeles, latitude $34^{\circ} 7^{\prime}$, longitude west $118^{\circ} 7^{\prime}$, by Assistant-Surgeon John S. Griffin, for ten months, from June, 1847, to March, 1848, inclusive. The monthly mean temperature was: June, $73^{\circ}$; July, $74^{\circ}$; August, $75^{\circ}$; September, $75^{\circ}$; October, $69^{\circ}$; November, $59^{\circ}$; December, $60^{\circ}$;

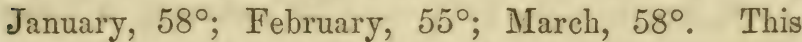
place is about forty miles from the coast.

“At San Diego, latitude 32 $45^{\circ}$, longitude west $117^{\circ} 11^{\prime}$, by Assistant-Surgeon J. D. Summers, for the following three months of 1849, viz: July, monthly mean temperature, $73^{\circ}$; August $75^{\circ}$; September, $70^{\circ}$.

"At Suttersville, on the Sacramento River, latitude $38^{\circ} 32^{\prime}$ north, longitude west $121^{\circ} 34^{\prime}$, by AssistantSurgeon R. Murray, for the following months of 1849 : July, monthly mean temperature, $73^{\circ}$; August, $70^{\circ}$; September, $65^{\circ}$; October, $65^{\circ}$.

"These observations show a remarkably high tempe- 
rature at San Francisco during the six months from October to March inclusive; a variation of only eight degrees in the monthly mean, and a mean temperature for the six months of 51 degrees.

"At Monterey, we find the mean monthly temperature of the seven months to have been $58^{\circ}$. If we take the three summer months, the mean heat was $60^{\circ}$. The mean of the three winter months was a little over $49^{\circ}$; showing a mean difference, on that part of the coast, of only $11^{\circ}$ between summer and winter.

"The mean temperature of San Francisco, for the three winter months, was precisely the same as at Monterey-a little over $49^{\circ}$.

"As these cities are only one degree and a half distant from each other, and both situated near the ocean, the temperature at both, in summer, may very reasonably be supposed to be as nearly similar as the thermometer shows it to be in winter.

"The mean temperature of July, August, and September, at San Diego, only $3^{\circ} 53^{\prime}$ south of Monterey, was $72^{\circ}$. The mean temperature of the same months at Monterey was a little over $59^{\circ}$; showing a mean difference of $13^{\circ}$.

"This would seem to indicate that the cold ocean current is thrown off from the southern part of the coast by Point Conception, and the islands south of it; and consequently its influence on the climate of San Diego is much less than at Monterey and San Francisco.

"At Los Angeles, 40 miles distant from the coast, the mean temperature of the three months was $74^{\circ}$; of the three autumn months, $67^{\circ}$; of the three winter months, $57^{\circ}$.

"At Suttersville, about one hundred and thirty 
miles from the ocean, and four degrees north of Los Angeles, the mean temperature of August, September, and October, was $67^{\circ}$. The mean temperature of the same months at Monterey was $59^{\circ}$; showing a difference of $8^{\circ}$ between the sea-coast and the interior, on nearly the same parallel of latitude. A much greater difference would undoubtedly appear, if we had observations for the spring and summer months of Suttersville and the gold mines.

"These variations in the climate of California account for the various and conflicting opinions and statements respecting it.

"A stranger arriving at San Francisco in summer is annoyed by the cold winds and fogs, and pronounces the climate intolerable. A few months will modify, if not banish his dislike, and he will not fail to appreciate the beneficial effects of a cool, bracing atmosphere. Those who approach California overland, through the passes of the mountains, find the heat of summer, in the middle of the day, greater than they have been accustomed to, and, therefore, may complain of it.

Those who take up their residence in the valleys which are situated between the great plain of the Sacramento and San Joaquin and the coast range of hills, find the climate, especially in the dry season, as healthful and pleasant as it is possible for any climate to be which possesses sufficient heat to mature the cereal grains and edible roots of the temperate zone.

"The division of the year into two distinct seasons - dry and wet-impresses those who have been accustomed to the variable climate of the Atlantic States unfarorably. The dry appearance of the country in summer, and the difficulty of moving about 
in winter, seem to impose serious difficulties in the way of agricultural prosperity, while the many and decided advantages resulting from the mildness of winter, and the bright, clear weather of summer, are not appreciated. These will appear when I come to speak of the productions of California. We ought not to be surprised at the dislike which the immigrants frequently express to the climate. It is so unlike that from which they come, that they cannot readily appreciate its advantages, or become reconciled to its extremes of dry and wet.

"If a native of California were to go to $\mathrm{New}$ England in winter, and see the ground frozen and covered with snow, the streams with ice, and find himself in a temperature many degrees colder than he had ever felt before, he would probably be as much surprised that people could or would live in so inhospitable a region, as any immigrant ever has been at what he has seen or felt in California.

"So much are our opinions influenced by early impressions, the vicissitudes of the seasons with which we are familiar, love of country, home, and kindred, that we ought never to hazard a hasty opinion when we come in contact with circumstances entirely different from those to which we have all our lives been accustomed."

These remarks explain the reason of the diversity of opinion expressed by persons who have visited California, in a very satisfactory manner. The Italian climate of Los Angeles has receired the praises of nearly all who have visited that city or its neighborhood. The themometrical observations detailed in the above account seem to prove that much of the unfavorable opinions expressed concerning the climate is 
the result of hasty judgment, and a dislike of that which is different from that to which we have been used.

The soil of California has also been the subject of various and conficting statements. Nany of those who have epent sone months in the country, and returned to pullish their hastily gathered observations, either set dom the soil as totally unfit for agricultural purposes, or, having been located in como garden spot the ereat portion of their time of resilence there, pronounce it unsurpassed for richness and fertility. As Mr. King rivited Callornia with the sole object of making accurate obscrations upon the territory and its resuurces, the statements of the character of the soil which are giren in his report will carry greater weight than any other. He says-

"The valleys which are situated parallel to the coast range, and those which extend castwardly in all directions among the lills, towards the sreat plain of the Sacramento, are of unsurpassed fertility.

"Whey have a lecp black alluvial soil. which has the appearance of having been deposited when they were corered with water. This illea is strengihcied by the fact that the rising grounds on the borders of these ralleys, and many hills of moderate eleration, have a soil precisely like that of the adjoining plains.

"This soil is so porous that it remains perfeetly unbroken by gullies, notwithstanding the great quantity of water which falls in it annually during the wet season. Whe land in the northern part of the territory, on the Trinity and other rivers, and on the borders of Clear Lake, as far as it has been examined, is said to be remarkably fertile.

"The great valley of the Sacramento and San 13 
Joaquin has evidently licen, at some renote poriod, the bed of a lake; and those rivers, which diain it, present the appearance of having cut their channels through the alluvial heposit afte? it had been furmer. In fact, it is not possible that they could hove been instrumental in forming the phin through which they pass. Their head-waters como frum the extreme ond of the ralley, north and south; and, were it not for the suply of water receivel from the streams which flow into them fiom the Siema Nerala, their beds would be alinost, if rite quite, diry in the summer months. The soil is vory rich, and, with a proper system of dirimge and embankwent, woull, undoubtedly, be capalule of producing any crop, cxcept sugarcane, now culliratul in the Alantic tates of the Union.

"There are tany beatiful ralleys and rich hillsiles among the foot-hills of the Siurra Nevala, which, when the profits of lalor in wining shall be reduced so as to causo its application to agriculure, will probably support a large por,ulation. There is said to be a rich belt of well-timberul and watered country extending the whole length of the gold region between it and the Sierra Nevalla, some twenty miles in whith. There is no informativn sufficiently accurate respecting the castern slope of the reat snowy range to enable th to fom any opinion of is general charater or soil. Some of its valleys have been visited by miners, who represent thein as upuil to any portion of the country to the westward of it.

"The great valley of the Culuralo, situated between the Sierra Madre and the Sicrra Nerada, is but little known. It is inhabited by numerous tribes of sarages, who manifest the most decided hostility towards the 
whites, and have hithorto prevented any explorations of their country, and do not permit emigrants to pass through it. Whercfore, parties from Santa Hí, on their way to Califoria, are compelled to make a circuit of near a thousani miles northward to the Salt Lake, or about the same distance sonthward by the route of the Gila. Although this valley is little known, there are indications that it is fertile and valuable.

"The name of the rirer 'Colorado' is descriptive of its waters; they are as decnly colored as those of the Missomi or Renl River, while those of the Gila, which we know flows throngh barren lands, are clear.

"It would seem impossible for a large river to collect sediment cnonch in a santy, barren soil, to color its waters so decply as to give it a name among those who first discovered and hare since risited its shores. The probability, therciore, is, that this river flows throngh an alluvial ralley of great fertility, which has never been explored. This conjecture is strengthenen by the fact that the Indians who inhaljit it are hostile, and oppose, as far as they can, all persons who attempt to enter or explore it. Whis has been their miform course of conduct respecting all portions of the eontinent which have been fertile, abounding in game and the spontaneous productions of the earth.

"As this valley is situated in the direct route from Santa Fé to California, its thorough exploration becones a matter of very great importanes, especially as it is highly probable that the elevated regions to the north of it, covered with snow during most of the year, will foree the line of the great national railway to the Pacifie through some portion of it.

"The soil I have described, situated west of the Sicrra Nevada, and embracing the plain of the Sucra- 
mento and San Joaquin, covers an area, as nearly as I can estimate, of between fifty and sixty thousand square miles, and would, under a proper system of cultivation, be capable of supporting a population equal to that of Ohio or New York at the present time."

If this account be accurate, the soil of California will yield a rich reward to the agriculturist, and become a strong attraction to permanent settlers, who are willing to trust to the more certain returns for labor spent in tilling it. It is agriculture, undoubtedly, which must give stability to the increase of the country, and, whatever may be the value of the gold mines, furnish California with her substantial wealth. Few cities or towns ever had a permanent prosperity which had not a neighboring country fit for agricultural purposes.

The quantity and quality of the present productions of California, other than her mineral wealth, is an important subject for inquiry. Previous to the discovery of the gold, the exportable products consisted almost exclusively of hides and tallow; the inhabitants paying more attention to the raising of horses and cattle than to the cultivation of the soil. The reason is found in the general characteristic of the Californians-indolence. Horses were raised to gratify their passion for riding; and cattle, because they afforded a subsistence at a very small cost of labor. As to what are, and what, by the character of the soil and climate, might be, the products of California, and how the wants of the people are to be supplied, we quote Mr. King's remarks:

"Beef cattle, delivered on the navigable waters of the Bay of San Francisco, are now worth from $\$ 20$ to 
$\$ 30$ per hearl; horses, formerly worth from $\$ 5$ to $\$ 10$, are now valued at $\$ 60$ to $\$ 150$. The destruction of cattle for their hides and tallow has now entirely ceased, in consequence of the demand for beef. This demand, will, of course, increase with the population; and it would seem that, in a very few years, there will be none to supply the market.

"If we estimate the number of cattle now in California at 500,000 head, which is believed to be about the number, and the population at 120,000 for the year 18.50 — a low estimate - and suppose it to increase one hundresl thousand per annum, there will be in the Territory or State, in 1851, five hundred and trenty thousand people.

"If we adopt the estimate of those well acquainted with the demand, of half a beef, on an average, to erch inhabitant, it appears there will be a consumption, in 1850, of 60,000 head; in 1851, of 110,000 ; in 1852 , of 160,000 ; in 1853 , of 210,000 ; in 1854 , of 260,000 -making an aggregate of 800,000 , which would absorb all the present stock, with its natural increase.

"This is a very important matter, as connected with the amount of supply which that country will ultimately require from the Atlantic States of the Union. There is no other country on earth which has, or will ever possess, the means of supplying so great a demand.

"It is now a well-established fact among the immigrants to California, that oxen possess greater powers of endurance than mules or horses; that they will perform the distance with loaded wagons in less time, and come in at the end of the journey in better condition.

"Cows are now driven in considerable numbars 
from Missouri, and the time camnet ic fir distant when cattle from the Western States will be driven annually by tens. of thousands to suply this new market.

"If California increases in population as fast as the most moderate estimate woulil lead us to believe, it will not be five years before she will require more than one hundred thousand head of becf cattle per annum, from some quarter, to supply the wants of her people.

"It must not be supposerl that salt provisions may supply this rast remand. Those who have attempted to live on such food, during the dry scisson, have been attacked with seurvy and other cutaneons diseases, of which many have died.

"There is no climate in the world where fresh meat and vegetalbles are more essential to human hoalth. In fact, they are indispensable.

"It must not be inferred that cattle driven across the plains and mountains, from the Wratern States, will he fit for beef on their arrival in California. But one winter and spring, on the luxuriant pastures of that country, will put them in a condition which wonk renter them acceptable in any Atlantie market.

"These grazing gromuls are extensive enongh to support fire times as many cattle as may lie ammenty required; therefore, there will be no scarcity of food for them.

"I am acpuainted with a drorer who left California in December last, with tho intention of bringing in ten thousand sheep from New Mexico. This shows that the flocks and herds enst of the Rocky Momtains are lookel to alrealy as the source from which the markets on the Pacific are to be supplied. 
"The climato and sul of Californin are well suited to the growth of whent, Astlogr rye, and onts. The tempernture alon? the cont is tho conl for the ancecssful culture of maixe as a fiell crop. The fict that onts, the species which is cullivatol in the Atlantic States, are ammally self-anved and produoded on all the plains and hills where the const, and as far inland. as the su-brcuse loas a marked influence on the climate, is sufferent proof that all the curoul fraine my be

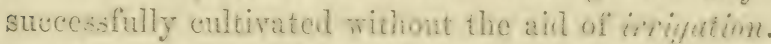

"It is fuite true that this andiling was cotensirely cmployed at the mission, and muloubiclly inexeased the product of all cropes (s) whioh it was applied, as it will in any country on enth if atifully userl. This does not prore, luwever, that it wes esentidly necossary to the proturion of an ample rowarl to the husbangman. The experionce of all the old inhabitants is sufficient cridenco of this. If their imperfect mole of culture socured satifactory roturns, it is rcamonable to premme that a more perfuet systom would produce much greater results. Thero is abundant evidence to prove that, in the rich allurial vallogs, wheat and barley luve produced from forty to simty bushels from one buhel of sect, whthert irrigation.

"Trish potatoes, turnipu, onions, in factull the enlible roots lmown and culdivated in the Atlantie states, are produced in great perfection. In all the valleys cast of the coast range of hille, the climate is sufricicitity warm to mature crops of Indiun corn, rice, ant probably tobacco.

"The cultiration of the grape has attracted much attention at the misions, among the resilents of towns, and the rurol population, and hewin attented with much succes, whererer it has been attempted. 
The diy scason sccures the fruit from those diseases which are so fatal in the Atlantic States, and it attains very great perfection.

"The wine made from it is of cxcellent quality, very palatable, and can be produced in any quantity. The grapes are delicious, and produced with very little jabor. When taken from the rines in bunches, and suspentied in a dry room by the stems, they become partially dry, retain their flavor, and remain several wecks, perhaps montis, without decay.

"Apples, pears, and peaches are cultivated with facility, and there is no reason to doubt that all the fruits of the Atlantic States can be produced in great plenty and perfection.

"The grasses are rery luxuliant and nutritious, affording excellont pasture. The oats, which spring up the whole length of the sea-coast, and from forty to sixty miles inland, render the cultivation of that crop cntirely unnecessary, and yield a very great quantity of nutritions food for horses, cattle, and sheop. This diry season matures, and I may say cures, these grasses aml oats, so that they remain in an excellent state of preservation luring the summer and autumn, and afiord an ample sumply of forage. While the whole surface of the country appears parcher, and regetation destroyerl, the numerons flocks and herds which roam orer it continue in excellent condition.

"Although the mildness of the winter montha, and the fertility of the soil, secure to California rery decided agricultural advantares, it is almitted that imilgation would be of rery great importance, and necessarily increase the proclucts of the soil, in quantity and rariety, during the greater part of the dry 
season. It shoul?, therefore, be encouraged by government, in the survey and disposition of the public lands, as far as practicable.

"The furmer derives some very important benefits from the dry scason. His crops in harvest time are never injured by rain; he can with perfect confidence permit them to remain in his ficlds as long after they hare been gathered as his convenienco may require; he has no fears that they will be injured by wet or unfarorable wcather. Ifonce it is that many who hare long been accustomed to that climate prefer it to the changeable weather cast of the Rocky Nountains.

"As already stated, the forests of California, south of latitude $39^{\circ}$, and west of the foot-hills of the Sierra Nevada, are limited to detached, scattering grores of oak in the valleys, and of red wood on the ridges and on the gorges of the liills.

"It can be of no practical use to speculate on the causes which have denuded so large an extent of country, further than to ascertain whether the soil is or is not farorable to the growth of forest trees.

"When the dry scason sets in, the entire surface is corered rith a luxuriant growth of grass and oats, which, as the summer advances, ljecome perfectly dry. The remains of all dead trees and shrubs also become dry. These materials, therefore, are rery combustible, and usually talic firo in the latter part of summer and beginning of autumn, which commonly passes over the whole country, destroying, in its course, the young shrubs and trees. In fuct, it scems to be the same process which has destroyed or prevented the growth of forest trees on the prairies of the Western States, and not any quality in the soil unfriendly to their growth. 
"The absence of timber and the continuance of the dry season are apt to be regarded by farmers, on first going into the country, as irremediable defects, and as presenting obstacles, almost insurmountable, to the successful progress of agriculture. A little experience will modify these opinions.

"It is soon ascertained that the soil will produce abundantly without manure; that flocks and herds sustain themselves through the winter without being fed at the farm-yard, and, consequently, no labor is necessary to provide forage for them; that ditches are easily dug, which present very good barriers for the protection of crops, until live fences can be planted, and have time to grow. Forest trees may be planted with little labor, and in very few years attain a suffcient size for building and fencing purposes. Time may be usefully employed in sowing various grain and root crops during the wet or winter season. There is no weather cold enough to destroy root crops, and, therefore, it is not necessary to gather them. They can be used or sold from the field where they grow. The labor, therefore, required in most of the old States to fell the forests, clear the land of rubbish, and prepare it for seed, may here be applied to other objects.

"All these things, together with the perfect security of all crops in harvest time, from injury by wet weather, are probably sufficient to meet any expense which may be incurred in irrigation, or caused, for a time, by a scanty supply of timber.

"In the northern part of the territory, above latitude $39^{\circ}$, and on the hills which rise from the great plain of the Sacramento and San Joaquin to the foot of the Sierra Nevada, the forests of timber are beau- 
tiful and extensive, and would, if brought into use; be sufficiently productive to supply the wants of the southern and western portions of the State."

It is not to be expected that the labor and attention necessary for the improvement of the soil will be given to that object, so long as the continued discovery of gold and other metals promise an easy road to wealth. Many who were prosperously engaged in agricultural employments, in the most fertile regions, have abandoned it, lured by the golden bait, and shouldered the pick and shovel to try their luck or perseverance at gold digging. The gardens and the vineyards of Los Angeles have been deserted for the barren hills and ravines where the precious dust abounds. In this state of things, California must become an extensive market for the products of the Atlantic States of the Union.

The extent and value of the public domain, and the validity of the titles to various tracts of land in California, will, doubtless, be the cause of much litigation and disturbance, as the country becomes more thickly settled. The relation in which the claimants of land granted to them under the Mexican government, stand towards the government of the United States, is clearly and fully set forth by Mr. King, in his California report. He says-

"It is not known whether the Jesuits who founded the mission, or their successors the Franciscans, ever did, or do now, hold any title from the Spanish crown to the lands which they occupied. Nor has any investigation been made to ascertain how far those titles, if they ever existed, have been invalidated by the acts of the priests, or the decrees of the Mexican gorernment. 
"A superficial view of the matter would be very apt to lead to the supposition that the Jesuits, so celebrated for wisdom and cunning, would not fail to secure that which, at that time, would probably have been obtained by merely asking for it-a royal decree, granting to them all the lands they might require in that remote country for ecclesiastical purposes. There have been some intimations to that effect, but nathing is distinctly known. These missions embrace within their limits some of the most valuable lands in the Territory, and it is very important that it should be ascertained whether they belong to the Government, or may be justly claimed by individals.

"Most of the land fit for cultivation, south of latitude $39^{\circ}$, and west of the valley of the Sacramento and San Joaquin, is claimed under what purport to be grants from the Mexican government.

" On most of these grants, the minerals and metals are reserved to the government: conditions were coupled with many of them which have not been complied with. In others, the boundaries described embrace two or three times as much land as the grant conveys.

"The Mexican law required all grants made by the provincial government, with few exceptions, to be confirmed by the supreme government. The great distance which separated them, and the unfrequent or difficult means of communication, made a compliance with the law so expensive and tardy that it came to be almost disregarded.

"There were other causes which led to this neglect.

"Previous to the treaty with Mexico and the immigration of American citizens to that country, land was not regarded as of much value, except for grazing 
purposes. There was room enough for all. Therefore, the claimants or proprietors did not molest one another, or inquire into the validity of titles.

"These extensive grants are described by natural boundaries, such as mountains, bays, and promontories, which, in many instances, might allow of a variation of several miles in the establishment of a corner with chain and compass.

"By the treaty of Guadalupe Hidalgo, the United States purchased all the rights and interests of Mexico to and in California. This purchase not only embraced all the lands which had not been granted by Nexico, but all the reserved minerals and metals, and also reversionary rights which might accrue to Mexico from a want of compliance on the part of the grantees with the conditions of their grants, or a want of perfection in the grants.

"It will be perceired that this is a subject of very great importance, not only to the people of California, but to the United States, and calls for prompt and efficient action on the part of the Government. It is believed that the appointment of competent commissioners, fully empowered to investigate these titles, in a spirit of kindness towards the claimants, with power to confirm such titles as justice may seem to demand, or with instructions to report their proceedings and awards to Congress, for confirmation or . rejection, will be the best and perhaps the only satisfactory mode of adjusting this complex and difficult question."

He also makes the following observations and recommendations concerning the exten ${ }^{+}$and ralue of the land, to which the title of the government is unquestionable, and the best mode of improving it. 
"The lands in the northern part of the Territory, above the $39^{\circ}$, have not been explored or granted. They are supposed to embrace an area of about twenty millions of acres, a large portion of which is doubtless valuable for its timber and soil.

"Comparatively few grants have been obtained in the great valley of the Sacramento and San Joaquin.

"This vast tract, therefore, containing, as is estimated, from twelve to fifteen millions of acres, belongs mostly to the Government. South of this valley, and west of the Colorado, within the limits of California, as indicated in her Constitution, there are said to be extensive tracts of valuable, unappropriated land; and, on investigation, it will probably appear that there are many of them in detached bodies, which have not been granted.

"I do not speak of the gold region, embracing the entire foot-hills of the Sierra Nevada, some five hundred miles long and sixty miles broad, in connection with the public domain, which may be embraced in the general land system for sale and settlement, for reasons which will be hereafter assigned.

"The survey of the public lands on a system suited to the interests of the country is a matter of very great importance. In the inhabited portions of the Territory, the boundaries of Mexican grants, running as they do in all directions, will render the system of surveys by parallels of latitude and longitude quite impracticable.

"In all parts of the country, irrigation is desirable, and its benefits should be secured, as far as possible, by suitable surveys and legal regulations. Most of the valleys are watered by streams sufficiently large to be rendered very useful. It would, therefore, seem 
wise to lay off the land in conformity to the course of the hills and streams which bound and drain the valleys.

"A system of drainage, which would also secure irrigation, is absolutely necessary to give value to the great plain of the Sacramento and San Joaquin. This valley is so extensive and level that, if the rivers passing through it were never to overflow their banks, the rain which falls in winter would render the greater portion of it unfit for cultivation. The foundation of such a system can only be established in the survey and sale of the land.

"This can be done by laying out canals and drains, at suitable distances, and in proper directions, and by leaving wide margins to the rivers, that they may have plenty of room to increase their channels when their waters shall be confined within them by embankments.

"It would be well also to regulate the price of these lands, so as to meet, in some degree, the expense of draining them.

"This system would, when agriculture shall become a pursuit in California, make this valley one of the most beautiful and productive portions of the Union."

With regard to the present state of the commerce and of the commercial resources of California, it is observed, that her resources are confined almost entirely to the metallic wealth of the country, and that such a state of things would seem unfavorable to an extensive commercial intercourse. Undoubtedly, this metallic wealth of itself, could not long maintain an extensive commerce with the various nations of the earth. But when the mineral wealth begins to be developed, as it soon will, there will be no lack of 
return freights for vessels arriving with supplies. The quicksilver mines already yield an enormous profit, and will soon be extensively worked. Respecting the present state of the commierce of the country, extent of her resources, and facilities of communication with the Atlantic States of the Union, and other countries, Mr. King's Report furnishes the following account-

"Gold is the product of the country, and is immediately available, in an uncoined state, for all the purposes of exchange. It is not there, as in other countries, where the productions of the earth and of art are sent to markets-foreign or domestic-to be exchanged for the precious metals, or other articles of value. There, gold not only supplies the medium of domestic trade, but of foreign commerce.

"At first view, this state of things would seem to be unfavorable to an extensive intercourse with other parts of the world, because of the want of return freights of home production for the vast number of vessels which will arrive with supplies.

"These vessels, however, making no calculations on return cargoes, will estimate the entire profits of the voyage on their outward freights, and become, on their arrival, willing carriers for a comparatively small consideration.

"This tendency in the course of trade, it would seem, must make San Francisco a warehouse for the supply, to a certain extent, of all the ports of the Pacific, American, Asiatic, and the Islands.

"Almost every article now exported by them finds a ready market in California, and the establishment of a mint will bring there also the silver bullion, amounting to more than ten millions per annum, from 
the rest coast of Mexico, and, perhaps, ultimately from Chili and Peru, to bo assayed and coined.

"Vessels bound round Cape Horn, with cargoes for markets on the American coast of the Pacific, can, by taking advantage of the south-east trade winds, and 'standing broad-off the Cape,' make the royage to San Francisco in as short a time as they can to Valparaiso, or any port south of California. Vessels hare sailed from our Atlantic ports to San Francisco in less than one hundred days, and they have been, in more than one instance, over one hundred and twenty days in going from Panama to San Francisco.

"This astonishing lifference in time and distance was caused by the course of the winds, and the gulfstream of the Pacific, mentioned in my remarks on the climate of California.

"The ressels from our Atlantic ports took adrantage of the winds by steering from the Cape as far into the Pacific as to be enabled to take a course west of the gulf-stream in sailing northward, thus availing themselves first of the south-east, then of the northeast ' trades,' and aroiding opposing currents.

"The ressels from Panama were kept back by calms, adrerse winds, and currents. It will be perceired, therefore, that there can be no inducement for ressels bound reund Cape Ilorn, with mixed or assorted carcgoes, to stop at Talparaiso, Callao, Guayaquil, or any port on the rest coast, because the exports of all those places will seek a market at San Francisco; and their supply of merchandise, as return fieight, will be delirered at less expense than it can be by ressels direct from Atlantic ports, American or European. This tendency of trade to concentrate at San Francisco will be aided by the course of exchange. 
"Gold dust is morih but $\$ 17$ per ounce in Cliili. It is worth $\$ 18$ at the United States mint. If, therefore, a merchant of Valparaiso has ten thousand ounces in San Francisco, receired in payment for lumber, barley, flour, or other produce, and desires an inroice of goods from the United States or Europe, he will gain $\$ 10,000$ at the outsct by sonding his gold to New Iork, besides saring something on the freiglit and insurance, and at least one montl's interest.

"The comntries on the west coast of America have no exports which find a market in China, or other parts of Asia. San Francisco will, therefore, become not only the mart of these exports, but also of the products and manufactures of India, requirel in ex- eliange for them, which must be paid for, principally, in gold coin or gold dust. Neither goid coin nor gold dust will answer as a remittance to China. Gold, in China, is not currency in any shepe, nor is it receired in payment of import dutios, or taxes on land, or on the industry of the people.

"The ralue of pure goll in China is not far from $\$ 11$ the ounce. Hence, the importer of manufactures and products of India into San Francisco will remit the gold coin or dust direct to New York, for inrestment in sterling bills on London. F'hese bills will be cent to London, ant placel to the creclit of the firm in China from whom the increhandise has beon reccircl, and who, on learning of the remittanco having gone forwarl to their agents, will draw a six month' sight bill for the amount, which will sell in China at the rate of four shillings and two pence or three pence per dollar.

"I have a statement before me from one of the 
mo:t ominont morchants and bankeis of Mrow Tork, who was for many rears mengent exturively in the Intlin trate, which slows thit the rinet or eain on ton thrmant ounces of eoln, thus remitter, would be

And that the loss on the same quantity,

sent direct to China, would be $\S 33,43144$

Total difference in profit and loss in favor of the remittance to New York, , 850,0?4 44 "It will thus be perceived that nature has so arranged the wimds and currents of the lodifice, aml di-poscel of her rast treasures in the hills and nomtains of California, as to give to the hurlore of San Francisen the control of the commerce of that ocean, as far as it may be connecterl with the wost const of America.

"Important as the commerec of the Pacifie undoubtedly is, ani will be, to Califomia, it enimot now, nor will it ever compare in magnitule aml ralue to the domestic trade between her and the older States of the Union.

"Two years aro, California did not probalily onntain more than fifteen thonsand people. That portion of it which has since been so wonderfully poopleal by Ancrican citizns was, comparatively, witlont inlislitants, without ressurces, and not suplierl with the common coniforts of shelter afforied by a forest country.

"Notwithstanling the great distanees immigrants have been compelled to travel to reach the territory, liore than one huntred thousand hare orepome all dififerilies and spreat themselves orer it, hills and plains. They have been supplied from distances as 
great as they themselves have passed with not only the necessaries, but the comforts and many of the luxuries of life. Houses have been imported from China, Chili, and the Atlantic States of the Union. All the materials required in building cities and towns have been added to the wants of a people so numerous, destitute, and remote from the sources of supply.

"These wants will exist as long as immigration continues to flow into the country, and labor employed in collecting gold shall be more profitable than its application to agriculture, the mechanic arts, and the great variety of pursuits which are fostered and sustained in other civilized communities.

"This may be shown by mentioning the prices of a ferw articles. Last summer and autumn, lumber was sold in San Francisco at $\$ 300$ to $\$ 400$ per thousand feet. At Stockton and Sacramento City, at $\$ 500$ to $\$ 600$. At these prices, it could be made in the territory, and many persons were engaged in the business. I perceive, by recent accounts, that the price had fallen at San Francisco to $\$ 75$. At this price, it cannot be made where labor is from $\$ 10$ to $\$ 15$ per day; and the difficulties attending its manufacture are much greater than in the Atlantic States. Lumber can be delivered in our large lumber markets for an average of the various qualities of $\$ 16$, and freighted to San Francisco for $\$ 24$, making $\$ 40$ per thousand feet. This price would cause the manufacture of it in California to be abandoned. We may add $\$ 20$ per thousand, to meet any increase of price in the article itself, or in the freight, and the result would be the same.

"It is probable that the demand, for several years 
to come, will not be less than twenty millions of feet per annum, which, at $\$ 40$ per thousand, will be $\$ 800,000$.

"When California comes to have a population of 200,000, which she will have before the close of the present year, she will require nearly half a million burrels of flour from some quarter, and no country can supply it so good and cheap as the old States of the Union. Including freight and insurance, this may be set down as an item of about $\$ 5,000,000$. The article of clothing, allowing $\$ 20$ to each person, would be $\$ 4,000,000$.

"There is no pretension to accuracy in these items, and they: may be estimated too high; but it is quite as probable they are too low.

"We have no data on which to found a calculation of what the value of the trade between the States cast of the Rigcky Mountains and California will be during the current year. I will venture the opinion, however, that it will not fall short of twenty-five millions of dollars. It may go far beyond that sum. At present, I can conceive no cause which will retard or diminish immigration.

"If the movement shall continue five years, our" commerce with that territory may reach one hundred millions per annum. This is doubtless a startling sum; but it must be borne in mind that we have to build cities and towns, supply machinery for mining, coal for domestic purposes, and steam navigation, and all the multifarious articles used in providing the comforts and luxuries of life, for half a million of people, who will have transferred themselves to a country which is to produce, comparatively, nothing except minerals and the precious metals, and whose pursuits 
will cnalue then to purchase. at any cost, whatever may be necessary for their purposes.

"It is chife to to inagine or calculate the effect which will he protuced (in all the industrial pursuits of the peolle of the (Hh States of the Cnion, by this withrlawal from them of half a million of producers, who, in their new homes and new pursuits, will yive coistome to a commerec amost equal in value to our forcign trade. Let no one, therefore, suppose the is not interested in the welfare of California. As well may he believe his interests would not be influenced by dusing rur ports and cutting of intercourse with all the world.

"The distance romal Cane Ilorn is so great that brent-stufls and many other articles of food deteriorate, and many ohers are so perishable in their nature that they would decay on the parsage. This would bo the ca:ce particularly with all limils of regetalics and undried fruits. Until some more specdy mode of communieation shall be established by which prodace can be transferred, the farmers and planters of the old States will not realize the full value of this new market on the Pacific.

"Many other important interests will be kept back, especially the consumption of coal. The American steaner:, now on that ocean, those on their way there, and others shortly to be sent out, will consume not far from one hundred thousand tons of coal per aunum. The searcity of rood in California will bring coal into ceneral use as fucl, as soon as it can be obtaincl at reasonalle prices. Suppose there may be, three years hence, forty thousand houses, which shall consume fire tons each per annun. This, with the steamers, would be a consumption of three hundred 
thousand tons. If delivered at $\$ 20$ per ton, it would compete successfully with the coal from Vancourer's Islant and New Holin', and amount to $86,000,000$. "The construction of a railroad across the Isthnus of Panama rivulil sccure the market for those articles against all competition.

"Some idea may be formed of the demand for them from the prices pail in San Francisco last autumn. Coal was solil at $\$ 00$ to 8100 por ton; potatoes $\$ 16$ per bushel; tamins aml onions for 25 to 621 cents each; eggs from $\$ 10$ to $\$ 12$ per dozen.

"The ilistance from Chagres to New York has recently been run in sercu days. The same speed would carry a steanlogat from Panama to San Francisco in ten days. Allow three lays to convey freight across the Isthmu, on a mailway, and both passchgers and freight will be convejed from New York to san Francisco in twenty days.

"This colerity of morement would secure for Anerican produce the entire market of Califoria, Sailing ressols nay bo succosfully employed between our Atlantic and galf ports and the terminus of tho railway on this sile of the Isthmus; and jropellers from Thuma tw fan Francisco. Those latter vessels will be fomil peculiarly suited to that trate; they can use their steam through the calms of the bay of Panama, and aguint leak-winds and currents going north, and thir sails with farorable winds and currents coming south.

"These moles of converance, in connection with the railroml across the Isthmus, vould be snfficiently expeclitions and cconomical to turn the tide of commeree, betwecn the Atlantic and Pacific States of the Union, into that channel. The tendency of our 
commerce on the Pacific to promote the employment of ocean steamers is of much importance as connected with the defence of our extensive line of coast from latitude $32^{\circ}$ to $49^{\circ}$, the protection of the whale fishery, and other branches of trade on that ocean. The establishment of a line of heavy steamers to China would promote all these objects; increase our intercourse with that country, and probably be the means of opening communications with Japan. Money wisely employed in promoting these objects, it is believed, would add more to the power and prosperity of the country than its expenditure on any general system of fortification at the present prices of labor and materials. There is one point, however, of such vast importance that no time should be lost in taking the necessary steps to render it perfectly impregnable - that is, the entrance to the harbor of San Francisco. On the strength of the works which may be erected to defend that passage will depend the safety of California in time of war with a maritime power. Permit a hostile fleet to cast anchor in the harbor of San Francisco, and the country would be virtually conquered.

"The coast has not been surveyed, nor has its outline been correctly ascertained. There are many rocks above and below the water-line, and small islands not mentioned or indicated on any chart, which render navigation near the land, especially at night, extremely dangerous.

"An accurate survey of the coast, to commence at. the most important points, the construction of lighthouses, and the placing of buoys in proper positions, are objects of much importance, and, it is not doubted, will attract the early attention of Government." 
We come now to that which has built up so rapidly this empire of the Pacific-the metallic and mineral wealth of California. As to the extent of the region, and indications of the existence of the gold, tomether with the atten lant geological formations, the statements of Mr. Fing's report will not be, nor have not been, gainsayed; lut as to the origin of the gold, whether in combination with quartz, or mixed with the sands of the ravines and streams, rarious opinions have been expressed by those who have spent considerable time in working and observing the different formations. That due weight may be given to both of the princial theories, we extract the observation and opinion of a person who farors the ilea of the gold haring been scattered orer the country, by a tremendous volcanic eruption.

"The gold found in every placer in California bears the most indubitalile marks of having, at some time, been in a molten state. In many parts it is closely intermixed with quartz, into which it has evidently been injected while in a state of fusion; and I have myself seen many pieces of gold completely coated with a black cement that resembled the lava of a rolcano. The rariety of form, which the placer gold of California has assumed, is in itself sufficient evilence of the fact, that it has been thrown over the surface while in a melted state. The earliest comparisons of the California gold were to pieces of inolten lead dropped into water. The whole territory of the gold region bears the plainest and most distinct marks of being volcanic. The soil is of a red, brick color, in many places entirely barren, and covered with a flinty rock, or pebble, entirely parched in the summer, and during the rainy season becoming a perfect mire. The 13 
formation of the hills, the succession of gorges, the entire absence of fertility in many portions, distinctly exhibit the result of a great up-hearing during past times. But there is one phenomenon in the mining region which defies all geological rescarch founded upon any other premises than volcanic formation. Throughout the whole territory, so generally that it has become an indication of the presence of gold, a white slate rock is found, and is the principal kind of rock in the mining region. This rock, instead of lying as slate rock does in other portions of the carth, in horizontal strata, is perpenticular, or nearly so; seeming to have been torn up from its very bed and left in this position. On the banls of the Nidule Fork are several excarations, which can only be accounted for unon the suppositivis, that they were at some time volcanic craters. There is one of these on the mountain side, about frre miles below the "Dig Bar;" from which, ruming down to the base of the mountains, is a wille gorge entirely destitute of verdure, while the earth around it is covered with shrubbery. This, I am fully convineed, was the bed of the lava stream that was thrown up from the crater; and in searching for gold at the very foot of it, I fornd several pieces entirely covered with tho black cement or lava, of which I have previously spoken. From all these evidences, I am fully satisfied that at some early date in the world's history, by some tremendous volcanic eruption, or by a succession of them, gold, which was existing in the form of ore, mixed with quartz rock, was fused and separated from its surrounding substances, and scattered through every plain, hill, and valley, over an immense territory. By its own gravity, and the continual washing of the 
rains, it sank into the earth until it reached a rock, or hard, impenetrable clay. It still continued washing and sliding down the hill-side, until it reached the rivers or ravines, and in the former was washed along with its current until it settled in some secure place in their beds, or was deposited upon their banks; and in the latter rested among the crevices of rocks." *

The following from Mr. King's report, presents the opposite theory, with its eridence in full. The two accounts are at variance both in regard to fact and theory. But that of Mr. King, who enjoyed every facility of obtaining information from observation, and from the statements of intelligent miners, is considered most reliable, in respect to matters of fact, and, therefore, of more dependence in forming a theory. He says-

"The principal formation, or substratum, in these hills, is talcose slate; the superstratum, sometimes penetrating to a great depth, is quartz. This, however, does not corer the entire face of the country, but extends in large bodies in various directions-is found in masses and small fragments on the surface, and seen along the ravines and in the mountains, overhanging the rivers, and in the hill-sides in its original beds. It crops out in the valleys and on the tops of the hills, and forms a striking feature of the entire country orer which it extends. From innumerable eridences and indications, it has come to bo the universally admitted opinion, among the miners and intelligent men who have examined this region, that the gold, whether in detached particles and pieces, or in veins, was created in combination with the quartz.

- Six Months in the Gold Mines, by E. Gould Buffum. 
Gold is not found on the surface of the country presenting the appearance of having been thrown up and scattered in all directions by volcanic action. It is only found in particular localities, and attended by peculiar circumstances and indications. It is found in the bars and shoals of the rivers; in ravines, and in what are called the 'dry diggings.'

"The rivers, in forming their channels, or breaking their way through the hills, have come in contact with the quartz containing the gold veins, and by constant attrition cut the gold into fine flakes and dust, and it is found among the sand and gravel of their beds at those places where the swiftness of the current reduces it, in the dry season, to the narrowest possible limits, and where a wide margin is, consequently, left on each side, over which the water rushes, during the wet season, with great force.

"As the velocity of some streams is greater than that of others, so is the gold found in fine or coarse particles, apparently corresponding to the degree of attrition to which it has been exposed. The water from the hills and upper valleys, in finding its way to the river, has cut deep ravines, and, wherever it has come in contact with the quartz, has dissolved or crumbled it in pieces.

"In the dry season, these channels are mostly without water, and gold is found in the beds and margins of many of them in large quantities, but in a much coarser state than in the rivers; owing, undoubtedly, to the moderate flow and temporary continuance of the current, which has reduced it to smooth shapes, not unlike pebbles, but has not had sufficient force to cut it into flakes or dust.

"The dry diggings are places where quartz contain- 
ing gold has cropped out, and been disintegrated, crumbled to fragments, pebbles, and dust, by the action of water and the atmosphere. The gold has been left as it was made, in all imaginable shapes; in pieces of all sizes, from one grain to several pounds in weight. The evidences that it was created in combination with quartz are too numerous and striking to admit of doubt or caril. They are found in combination in large quantities.

"A very large proportion of the pieces of gold found in these situations have more or less quartz adhering to them. In many specimens, they are so combined they cannot be separated without reducing the whole mass to powder, and subjecting it to the action of quicksilver.

"This gold, not having been exposed to the attrition of a strong current of water, retains, in a great degree, its original conformation.

"These diggings, in some places, spread over valleys of considerable extent, which have the appearance of an allurion, formed by washings from the actjoining hills, of decomposed quartz and slate earth, and vegetable matter.

"In addition to these facts, it is, beyond doubt, true that several rein-mines have been discorered in the quartz, from which numerous specimens have been taken, showing the minute connection between the gold and the rock, and indicating a ralue hitherto unknown in gold-mining.

"These veins do not present the appearance of places where gold may have been lodged by some violent eruption. It is combined with the quartz, in all imaginable forms and degrees of richness.

"The rivers present very striking, and, it would 
seem, conclusive evidence respecting the quantity of gold remaining undiscovered in the quartz veins. It is not probable that the gold in the dry diggings, and that in the rivers - the former in lumps, the latter in dust-was created by different processes. That which is found in the rivers has undoubtedly been cut or worn from the veins in the rock, with which their currents have come in contact. All of them appear to be equally rich. This is shown by the fact that a laboring man may collect nearly as much in one river as he can in another. They intersect and cut through the gold region, running from east to west at irregular distances of fifteen to twenty, and perhaps some of them thirty, miles apart.

"Hence it appears that the gold veins are equally rich in all parts of that most remarkable section of country. Were it wanting, there are further proofs of this in the ravines and dry diggings, which uniformly confirm what nature so plainly shows in the rivers."

It is an interesting inquiry-what was the amount of the golden treasure collected during the years 1848 and ' 49 ? The satisfaction of this inquiry will enable us to form some faint conception of the value of the gold region, and the dependence which may be placed upon its yield for a commercial return. Premising that the gold was first discovered in May, 1848, and that intelligence of it was not received in the United States till late in the following autumn, Mr. King, in his report, proceeds in making an estimate of the quantity accumulated till the close of 1849 :

"No immigration into the mines could, therefore, have taken place from the old States in that year. The number of miners was, consequently, limited to 
the population of the territory, some five humdred men from Oregon-Mexicans, and other foreigners, who happened to be in the country, or crme into it during the summer and autumn-and the Indians, who wero employed by or solr their gold to the whites.

"It is supposed there wore not far from five thousand men employed in collecting gold during that season. If twe suppose they obtained an average of one thousand dollars each-which is regarded by well informed persons as a low estimate-the aggregate amount will be $\$ 5,000,000$.

"Information of this discovery spread in all directions during the following winter; and, on the commencement of the dry season in 1849 , people came into the territory from all quarters-from Chili, Peru, and other States on the Pacific coast of South America; from the wist coast of Mexico, the Sandwich Islands, China, and New Holland.

"The immigration fiom the United States came in last, if we except those who crossed the Isthmus of Panama, and went up the coast in steamers, and a few who sailed carly on the royage round Cape Ilorn.

"The American immigration did not come in by sea, in much force, until July and August, and that overland did not begin to arrive until the last of August and first of Septomber. The Chilenos and Mexicans were early in the country. In the month of July, it was supposed there were fifteen thousand foreigners in the mines. At a place called Sonoranian Camp, it was believed there were at least ten thousand Iexicans. They had quite a city of tents, booths, and log-cabins; hotels, rcotaurants, stores, and shops of all descriptions, furnished whatever money could procure. Ice was brought from the Sierra, and ice- 
creams added to numerous other luxuries. An inclosure made of the trunks and branches of trees, and lined with cotton cloth, serred as a sort of amphitheatre for buli-ights. Other amusements, characteristic of the Mexicans, were to be seen in all directions.

"The foreigners resorted principally to the southern mines, which gare them a great superiority in numerical force over the Amcricans, and enabled them to take possession of some of the richest in that part of the country. In the carly part of the season, the Americans were mostly employed on the forks of the American, and on Bear, Uba, and Feather Rivers. As their numbers increased, they spread themselves over the southern mines, and collisions were threatened between them and the foreigners. The latter, however, for some cause, either fear, or having satisfied their cupidity, or both, began to leave the mines late in August, and by the end of September many of them were out of the country.

"It is not probable that, during the first part of the season, there were more than fire or six thousand Americans in the mines. This would swell the whole number, including foreigners, to about twenty thousand the beginning of September. This period embraced about half the season, during which gold may be successfully collected in the rivers.

"Very particular and extensire inquiries respecting the daily earnings and aequisitions of the miners lead to the opinion that they areraged an ounce per day. This is believed by many to be a low estimate; but, from the best information I was able to procure, I am of opinion it approaches rery near actual results. The half of the season, up to the 1st of Sep- 


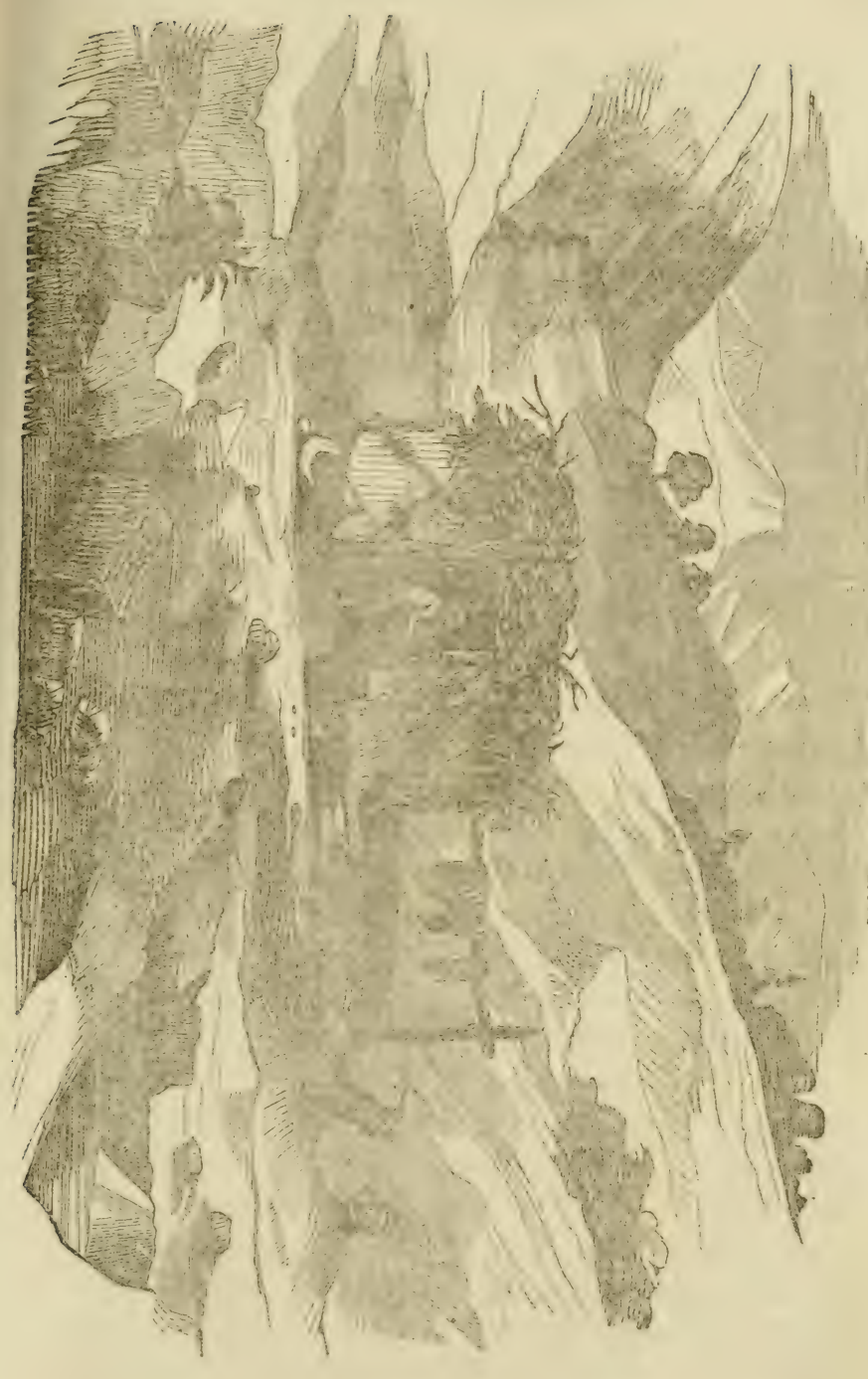



tember, would give sixty-five working days, and to each laborer, at $\$ 16$ per ounce, $\$ 1,0 \div 0$. If, therefore we assume $\$ 1,000$ as the average collected by each laborer, we shall probably not go beyond the mark.

"This would give an aggregate of $\$ 20,000,000$ for the first half of the season- $\$ 15,000,000$ of which was probably collected by foreigners. During the last half of the season, the number of foreigners was very much diminished, and, perhaps, did not exceed five thousand. At this time, the American immigration had come in by land and sea, and the number of our fellow-citizens in the mines had, as was estimated, increased to between forty and fifty thousand. They were most of them inexperienced in mining, and it is probable the results of their labors were not so great as has been estimated for the first part of the season, and experienced miners. Assuming that the average of half an ounce per day ought to be considered as reasonable, it would gire an aggregate of about $\$ 20,000,000$. If from this we deduct one-fourth on account of the early commencement of the wet season, we have an estimate of $\$ 15,000,000$; at least five of which was collected by foreigners, who possessed many advantages from their experience in mining and knowlerlge of the country.

"These estimates gire, as the result of the operations in the mines for $18+8$ and $18-19$, the round sum of $\$ \frac{1}{2} 0,000,000$; one-lalf of which was probably collected and carried out of the country by foreigner's.

From the best information I could obtain, I am led to believe that at least $\$ 20,000,000$ of the $\$ \$ 0,000,000$ were taken from the rivers, and that their richness has not been sensibly diminished, except in a few locations, which had early attracted large bodiea $r$ ? 
miners. This amount has principally been taken from the northern rivers, or those which empty into the Sacramento; the southern rivers, or those which flow into the San Joaquin, having been, comparatively, but little resorted to until near the close of the last season. These rivers are, however, believed by those who have risited them, to be richer in the precious metal than those in the northern part of the gold region."

Adopting the hypothesis that the gold found in these streams had been cut or worn away from the veins in the quartz through which they have forced their way, and considering the fact that they are all equally productive, we may conjecture what a vast amount of treasure remains undisturbed in the veins which run through the masses of rock over a space of forty or fifty miles wide, and near five hundred miles long. Such an estimate would almost defy our belief; yet, if the hypothesis is true, there is no reason to doubt that the value of the gold which that region will yield, is almost beyond calculation.

The quicksilver mines of California are believed to be numerous, extensive, and very valuable. The largest and most profitable one yet opened is situated near San José, and belongs to, or is claimed by, Mr. Forbes, of Tepic, in Mexico. The cinnabar ore, which produces the quicksilver, is easily procured, and machinery has been put in operation, which enalles the proprietor to make an extensive profit. The value of the quicksilver mines, by being so near the gold region, is considerably increased; quicksilver being almost indispensable in gold mining.

Extensive beds of silver, iron, and copper ores are believed to exist in the territory, but their existence 
and value is not accurately ascertained, the allurements held out by the continued success of the gold. miners and the continued discovery of new and profitable placers being too strong to permit any search for the baser, but more uscful metals. Respecting the propriety of the establishment of a mint in California, Mr. King makes the following observations-

"I have already alluded to the propriety of establishing a mint in California. This is important in many respects. At this time, there is not coin in the country to supply a currency. Much difficulty is experienced in procuring enough to pay the duties on imported goods. The common circulating medium is, therefore, gold dust, which is sold at $\$ 1550$ to $\$ 10$ per ounce. In the mines, it is frequently sold much lower. The miners, the laboring men, are the sufferers from this state of things.

"Those who purchase and ship gold to the Atlantic States make large profits: but those who diy lose what others make.

"I have estimated that there will be $\$ 50,000,000$ collected during the current year. At \$16 per ounce, that sum will weigh $3,125,000$ ounces.

"Gold, at the Lnited States mint, is worth $\$ 18$ per ounce, making a difference in ralue on that quantity, between San Francisco and New York, of $\$ 6,250,000$, which fould be sared to the miners by the establishment of a mint.

"I have also suggested its importance as a means of promoting and increasing our trade with the west coast of Mexico and South America.

"It is not doubted that the construction of a railway across the Isthmus of Panama, and, perhaps, the establishment of other lines of communication between 
the two oceans, will give to the products and manufactures of the older States of the Union command of the market of California to the exclusion, in a great degree, of those of the west coast.

"A mint will, therefore, become of the utmost importance, to give such marketable value to silver bullion as to enable the merchants of those countries to keep up and increase the intercourse with our principal ports on the Pacific.

"The silver bullion shipped to Europe from the west coast of Mexico amounts to more than ten millions of dollars per annum. From the countries on the west coast of South America, probably an equal quantity. That from Mexico goes to pay for European importations into her ports on the Atlantic side.

"A market at San Francisco for this bullion will be the means of substituting American and Chinese fabrics for those of European manufacture in all those countries. This will greatly increase the trade between China and California."

A bill for the establishment of a mint at San Francisco was introduced into Congress, during the present session, (1849-50) and passed both houses; thus securing to California the advantages mentioned in the above extract, by Mr. King.

We have thus given a complete description of California, in respect to population, climate, soil, productions, commercial resources, and metallic and mincral wealth, as accurate and comprehensive as the most authentic sources could furnish, or as could be ascertained at the present time. Although the territory already contains a large population and has produced a great amount of treasure in the short dura- 
tion of its existence; although it is already a large State, which has sprung into existence, as it may be termed, there is every evidence that this is but the "beginning of the end." "The greatest is behind." To what such commercial facilities, mineral and metallic resources, and an actire and progressive population will conduct California, it is easy to imagine. They will build up a State, which, although the member of a confederacy, will be powerful enough to maintain itself, independent of the aid to be derired from the Union. Its ports will be the resort of the ressels of all nations, and its valleys and hill-sides will become the homes of an agricultural population, reaping the rich reward of their toil. Canals and railroads, the children of enterprise, will soon intersect the territory, transport the riches of one section to another, and increase the social communication of the inhabitants. Such a State will add greatly to the power of the confederated republic, and form an additional stimulus to the rapid filling up of the rast territory situated between California and her sister States.

\section{CHAPTER XI.}

THE DIFFERENT ROUTES TO CALIFORNIA, AND THEIR RESPECTIVE CHARACTERS:

The various routes taken by the emigrants to California have afforded almost as much matter for discussion as the territory itself. The shortest and most travelled route is that by way of the Isthmus of 
Panama; and of this we shall first give a description, with recommendations to travellers, and the experience of some who have taken that route to the "land of promise."

Both steam and sailing vessols are constantly engaged in carrying freight and passengers from the principal ports of the Atlantic States to Chagres, the principal port on the eastern coast of the Isthmus. Tickets which will carry passengers to Chagres, and, after crossing the Isthmus, from Panama to San Francisco, can be purchased in New York, from whence to Chagres, the passage gencrally occupies about eight days, and has been accomplished in seven. The harbor of Chagres is a small but good one, for vessels of less than two hundred tons burden. It is protected by hills on all sides and towards the ocean, by a beetling cliff, jutting out into the sea, on the summit of which is the ancient and somewhat dilapidated castle of San Lorenzo. At the base of this cliff is the channel which forms an entrance to the town. Ignorance of this fact caused the wreck of several of the vessels which went from the United States to Chagres soon after the receipt of the news of the gold discovery. The following is a description of Chagres and its inhabitants in the early part of 1849 . It has since improved considerably, on account of the travel across the Isthmus.

"The first thing which struck our wondering gaze on entering Chagres, was its bee-hive appearance. It is a strange, fantastic, and oddish-looking town, situated in a deep, dark hollow or cove. It consists of some forty or fifty huts, with pointed palm-thatched roofs, and reed walls. Nor were the innumerable buzzards which were flying about or resting on the 
louses, together with the energetic gesticulation of the natives when in conversation, as we drew near, at all calculated to lessen the picturesque effect of a first view. The surrounding country was any thing but devoid of interest and beauty. All had a strange, equatorial look; while the green hills around, clothed with rich tropical verdure, and the graceful and shadowy palm and cocoanut, with other strange fantastic trees, together with the ruins of the large old Spanish castle, on the heights above the torn, gave to the scenery a very beautiful and picturesrue aspect.

"Most of us were soon ashore and rambling through the town. We landed at the beach, on some logs, which, during the rainy season, are necessary to preserve the pedestrian from a quagmire, in the midst of dense foliage that was here luxuriant to the water's edge, surrounded by about thirty canoes and some forty or fifty huge black fellows, mostly in the garb in which nature arrayed them. We passed on beneath a burning sun, which in the shade brought the thermometer to $90^{\circ}$ of Fahrenheit. A majority of the natives are black, but some are of a deep copper or mulatto color. The thick lips and woolly head of the African; the high cheek-bones, straight hair, and dogged look of the Indian; and the more chisled features and finely expressive eyes of the Spaniard, are all here, though often so blended, that it is difficult to say to which race they chiefly owe their origin. In truth they are a mongrel race, but generally have the most magnificent, large, lark, expressive eyes I have ever seen. These, when in conversation, which is almost continual, they use to some purpose, while the incessant rapid clatter of their tongues, and their violent gesticulations and grimaces, are often quite 
ludicrous. The females, some of whom have rather pretty faces, and particularly fine eyes, were dressed out in the most tawdry finery, with divers furbelows, flounces, and ruffles, encircling the shoulders, where the dress begins, and terminating somewhere about or below the knce. Some of the younger ones were entirely model artiste, at least so far as their clothing was concerned, but the forms of most were rather indifferent. Many were sitting or lounging about the doors or in the cabins, eating tamarinds, oranges, and other fruit, surrounded by hairless dogs, pigs, naked children, turkey-buzzards, and some other little live stock, forming altogether quite a congruous and homogeneous mixture.

"In a country like this, where the temperature is so nearly alike throughout the year, there is a natural tendency to indolence and sloth, and it is remarkable what an influence the climate exerts on the character of the people. Here nature with a bounteous hand spontaneously fructifies the earth, and the natives, with few wants to supply, pluck the fruit and are satisfied; and with few necessities for cnterprise and industry, such is their love of indolence, that all the charms of existence appear to consist in dreaming away life in quiet and repose. Basking beneath a tropical sun, or listlessly reclining on nature's downy couch, days-years-are passed in drowsy languor and supine sloth.

"But the influx of men from rougher climes and bleaker regions will probably exercise a salutary influence, by showing them the advantages of industry and patient toil. Already they begin to perceive this, to some extent, and though such dear lovers of money, that in closing a bargain they will jabber their 
patois, or bad Spanish, with uncouth gesticulations, for half a day, the majority of them are unwilling to make any extra bodily effort to procure it; but when persuaded by liberal offers to undertake a task; it is astonishing with what dogged persererance they will often pursue it, what weights they can support, and what toil they can endure."*

It is recommended that passengers from the States should remain as short a time in Chagres as possible. The exhalations from its malarious atmosphere are extremely prejuclicial to the health of the new-comer.

From Chagres, the travellers proceed in canoes up the Chagres rirer, to Gorgona, a distance of about fifty miles, or eight miles further, to Cruces. The canoes are mostly owned by the natives, and the greatest care is necessary to get them to keep their agreement. The usual plan by which their services are secured, is this: A bargain is made with the owner of the canoe, stipulating for the necessary captain and polesmen, and then some of the party going up the river in the canoe, take possession of it, and maintain it, while one goes before the alcalde, and pays the whole amount agreed upon, taking a receipt in Spanish. This precaution is rendered necessary; the proprietor of the canoe returning the money to those who engaged it, on finding he can obtain a greater price from others. At the present time, ressels, steam and sailing, are being constructed at Chagres, for the passage up the river, the increase of the Isthmus travel rendering it both necessary and profitable.

The beauty of the country through which the Chagres river flows has been the theme of frequent praise. Its banks are filled with all the luxuriant

- Diary of a Physician in California, by James L. Tyson, M. D. 
verdure which tropical climes produce. The tamarind, the date, the pomegranate, the plantain, the banana, the cocoanut, the lime, the citron, and the pine apple, are abundant. Flowers of every hue send forth their fragrance upon the air, rendering its sweetness delightful to the senses. Orange groves are numerous, and the fruit is as plentiful as the apple of the Southern States of the Union. Mountains, hills, and valleys diversify the prospect, while the ear is filled with the melodious notes of thousands of birds, native of the tropics, their music contrasting with the discordant noise of the parrots, mackaws, and chattering monkeys. Such a scene is worth the travel to the Isthmus, and the toils sometimes endured in crossing it.

Several small tomns and ranches are scattered along the banks of the river. The first is Gatun, ten or twelve miles above Chagres. About ten miles further is Dos Hermano; further on, Pûro Blanco, and Palenquillá last, about two-thirds of the way to Gorgona. These are stopping places for the canoes, where refreshments and supplies can be procured.

At night, parties that land are compelled to build fires to keep off the wild beasts and venomous serpents, which abound in the neighborhood of the river, and to disperse the myriads of insects with which the air teems. Alligators of a large size, are to be seen lying on the banks in the day time, basking in the sun. Above Palenquilla are some powerful currents, which it requires considerable toil to move against. The river is in some places a half a mile wide, and in others, not more than thirty yards. The boatmen are exceedingly indolent, and require constant driving and coaxing to keep them moving; but sometimes, 
when they are prevailed upon to go to work, they will exhibit an endurance and perseverance almost astonishing. They have been frequently known to work at the poles, pushing the boat along, for twenty-four hours, without rest. The difficulty of ascending the Chagres river, may be appreciated, when it is stated, that although Gorgona is only fifty miles from the town of Chagres, it frequently occupies as high as forty hours for the canoes to reach that place. Stoppages are, of course, numerous, both on account of the tiring of the boatmen and for refreshment.

"Gorgona is located upon a bend of the river, from which a fine view of the rirer and valley is obtained. The valley is here about five miles wide, the mountains rising from it in successive ranges, and with increasing elerations. It is an admirable location for a town, and must become one of considerable importance-especially should it be on the route of the proposed railroad across the Isthmus. It has a far better appearance than Chagres; the streets are laid out with some pretensions to regularity. It is the head of canoe narigation, and steamboats of light draft can approach it. The dwellings or huts are of a better class than those at Chagres; they have an unfinished Catholic church that looks rude and ragged, but nerertheless, it is a church. The carrying trade is now almost the only business pursued by its inhabitants; what they did before the gold of California began to invite a swarm of adventurers across the Isthmus, to the town is more than can be divined. Theirs must have been as near a pastoral or primitive life, as any that can be secn in our day. The soil is teeming with the evidences of its richness-inviting the hand of man to its cultivation, by showing what 
it is capable of doing without it-but it is undisturbed, save in a few stinted spots of less size than our ordinary kitchen gardens. All else is left to spontaneous production. They have herds of cattle; these, with game, flesh, fish, and fowl, easily procured, must have been their principal sustenance. But it is with them as with the rest of the world, wants increase with the facilities for gratifying them. They are rapidly changing their habits since they have an opportunity to earn money and luxuries, that they have been strangers to, are brought within their means and their reach.

During the dry season, which lasts from December till June, the road from Gorgona to Panama is generally preferred; at other times, the canoes proceed up the river about eight miles, to the town of Cruces, and take the road leading from that place to Panama. Each of these rolites shall receive our consideration, and their respective advantages and disadvantages be set forth. It is advisable, that travellers should rest as short a time as possible at Gorgona, as accommodations are of very poor character. Mules and a small species of mustang are easily obtained, but the mule is far preferable. Some travellers find it a great relief to walk a part of the distance, and, with that intention, parties hire mules or horses in the proportion of two to every three travellers. The baggage will have to be placed under the charge of the native muleteers, but, from their observed habits of filching wherever they get a chance, it is advisable not to trust them out of sight. There are several places upon the route where refreshments can be procured; but most of the travellers start at daylight from Gorgona, and push directly through to Panama, in one 
day. This is the best mode of proceeding, if the fatigue is found to be endurable; for it is above all things important that in such a climate too great fatigue should be avoided. The following account of a journey to Panama by way of the Gorgona road, and descriptions of the road is from a recently published narrative :

"We arose from cot and hammock, flea-bitten, and but little refreshed, though ready to start on what we deemed our perilous journey across the Isthmus. Hour after hour elapsed, till the most pleasant part of the day was gone, and the sun shone with torrid fervor; but still our mules were not ready, our host kceping them back, as we afterwards learned, to obtain a higher rate. Annoyed beyond endurance at the delay, and the tardy movements of the worthless set around us, we scoured the town, and at length succeeded in obtaining four miserable-looking little animals at eight dollars a-piece. Another was still wanting, and, by an offer of ten dollars, I at length succeeded in getting a tolerably good one. Though so wretched in appearance, we found these animals capable of great endurance.

"Glad that the rexatious and irritating events of the morning, which the cupidity and dogged laziness of these slothful mongrels had produced, were happily ended, we hastily swallowed a cup of bad coffee, handed by a damsel nearly nude, and mounting our Rosinantes, we started at a brisk canter, beneath a broiling sun, while our guido, all stripped and on font, trotted off in advance.

"For the first mile, the way was very pleasant over a nearly level plain, at the termination of which there were stronger indications of rougher riding, for we 
soon began to descend a nearly perpendicular precipice, the only pass, down which was a narrow muleway, where, step by step, these animals had worn a passage, over rocks, loose stones, sand and mud. We at length reached the bottom of the ravine, and, crossing a brook, which in some parts was a wide and deep chasm, we commenced a toilsome ascent on the opposite side, over a similar pathway, surrounded by scenery of wild and unknown plants and trees, on the mountain and glen, through whose dense foliage a breath could scarcely penetrate. The ferrent atmosphere produced an almost stifling sensation, while the deathlike silence that reigned throughout, disturbed only by the audible footfall of our animals, as we slowly wound around the tortuous ascent, made the journey peculiarly toilsome and solitary.

"For the first few miles I followed closely at the heels of our guide, and would often pause and turn to examine the apparently almost impassable route I had traversed, watch the progress of the rest of the party, and wonder at the security with which their cautiouslystepping and sagacious animals would gradually overcome seemingly insurmountable obstacles. These mustangs and mules, early trained to travel ' in the wild mountain track,' are capable of great endurance, and certainly possess much more knowledge than most of their riders, when exercised upon what they consider the safest and surest stepping-place, and best mode of proceeding. I urged mine repeatedly, to make him choose a path, which to all appearance was preferable to his own, but to no purpose. He would turn half round, and in a slow, solemn way, put his nose to the ground, and looking keenly about the place, would cautiously put one foot forward, then another, then a 
third and a fourth, when, poised on all dramn under him, and chose together, he would bare a betor opportunity for further inspection, which haring satisfactorily accomplishe, anolher equally teliberate ami cautious elep would be made es before. down what, to all appeartuces, was an impractimalso pente, anl so on, mitil the diffently was orereme. Finding that he knew so mulh bewer thin I dirl, low, where, and when les on hit in travel, I invariably thew the reins to him, when hazavdou: pasecs or othor obstaries were to be sumounterl. The result was always fortunate. One or two of the party. however, were satisfel that 'horses shomlil not have their own way' and whipped and spurmet theis to such an extent, to compel complianee with their better joulgnont. that the is we was as I hat anticiputed. One was thrown orer his horse's heal into a wad pulle, and the other, with horse and all, stuck fut in in cuagmirv, from which it was not easy to extricate lim. Shoull these lines ever meet the eye of thoso worthy gontumen, I trust they will partun the liberty Ihuve taken in recorling here their feats of maleshif. It is true that mine stumbled on some loose stomes oner or twice, in descending hills, and my efores alono with the reins saren both him and me from a fall; but for mmistakcalle judghent in traversing these periluns mountain-pases, I must adinit he frored himself the better of the two.

"Thns wo trudger on, often orer dimeult, and sometimes dungerum ways. Oecasionally we would have to ge up or (lown, as the case might be, for nearly haif a mile at one time, through a chasm or sluice, probably worn in the mountains by the torrents of vater that descend during the rainy season. These gully-holes are often ten and fifteen feet dcep through- 
out their entire extent, and the passes are so narrow, as barely to admit of one horse or mule passing through at a time; the rider, to avoid a sovere contusion, or probably a broken limb, in turning the sharp angles, being compelled to place his feet as near the animal's head as possible, and in this manner he can ride in perfect safety, though some little management is requisite to maintain an equilibrium. Before entering these defiles, the muleteers shout at the top of their voices, and stop for a short time, continuing the shouting as they advance, to apprize others at the opposite extremity of the pass, that the way is already occupied. This is necessary and important, for if two on horseback were to meet in one of these narrow but crooked paths, the scene between the Quaker and Dandy would have to be re-enacted, for many newspapers would have to be read, and many segars smoked, before either could turn out of the way for his neighbor.

"Continuing on, we passed two or three hackalas, or huts, by the way, and after several brief but pleasant stoppages at the various brooks and mountain-rills, we at length came out on a beautiful undulating meadow, where picturesque villas and shadowy trees decked the verdant plain, and soon thereafter the towers of Panama were in view. The sun was just sctting as we entered the suburbs, and a flood of purple glory rested on the sky, reflected back by the sparkling waters of the Pacific, which brought the distant mountains into bolder relief, and cast a deeper shadow through the twilight groves. Half an hour's ride over the paved street, brought us to the city, which we entered at the ' Gorgona gate,' passing through a heavy stone arch- 
way, supporting a cupola, in which hangs the alarm bell mounted by a cross."*

Such is the character of the Gorgona road to Panama. With regard to the Crucis road, we may observe that it is a common practice, for most of those who take the Grorgona road in going to Panama, on their return, to take the Crucis road, no doubt hoping that the difficulties and toil to be encountered are less than those they know are to be met with upon the other. The following account of a return journey by way of the Crucis road, with the full character of the route, is given in the journal of a returned adventurer.

"I had passed three days in Panama; and, feeling desirous of continuing my journey, I had no sooner concluded this arrangement, than I got my mule saddled, and my box and carpet-bag packed in the regular Isthmus fashion. The mule I obtained, like most of his fellows, was little better than a mere skeleton; but still it was the best I could procure, and I was fain to content myself with it. Some of my friends endeavored to persuade me that it was better to proceed on foot; but I knew the muddy and stony nature of the road, and thought it infinitely more comfortable to ricle a slow animal than subject myself to the sufferings that I must experience from these inconveniences. "The negro, I had hired, brought to my hotel a long frame of bamboo, with a sort of basket at the end, into which he crammed my luggage. This frame had two straps fastened to the upper part of it, through one of which he slipped his arm, whilst he passed the other over his left shoulder, and attached it under the latter to the frame which was now on his back. This contrivance not only effectually

- Diary of a Physician in California, by James L. Tyson, M. D. 
secures the load in its place, but protects the shoulders of the bearer from the continual friction they would otherwise undergo.

"A large party had preceded me; but I felt no anxiety to overtake it, as there was little or no danger of my encountering violence on the route. I was - armed with a good revolving pistol, in the event of any thing of the sort presenting itself; so that, all things considered, I was just as well pleased to be left to my own society.

"I proceeded on my route with my sable attendant, and found the commencement pleasant enough travelling, the road for some distance being paved with large and regularly cut stone. This, however, soon terminated in abundance of sand; the route still continuing dry, and comparatively easy to what I had expected to find it. Soon after we had quitted the pared road, the negro stopped and asked my permission to take a few things to his family, who lived in a small hut to our left. Apprehensive that he was meditating an escape with my luggage, I replied that I had no objection, provided he would leave his basket in my care. He accordingly took the frame off his back, and, separating a small bundle containing provisions from my baggage, he took his departure. I took care, however, to keep him in sight and saw him enter a wretched-looking bamboo-hut at a little distance from the route. He remained absent a considerable time; and, having paid him half his wages in adrance, according to the usual custom with these people, who are exceedingly distrustful, I began to fear that he was about to desert me, and therefore called out lustily, until at last I saw him reluctantly emerge from the hut, and make his way towards me. 
These negroes being constantly in the habit of deserting travellers on the ronte, and stealing their baggage whenerer the opportunity presents itself, I was particularly careful not to lose sight of my attendant.

"A few miles further on, I again found myself on a stone road, said to have been pared by Cortes to facilitate the passage of his troops from the Atlantic to the Pacifie coast; and, although I have travelled rougher and steeper routes in Lower California, I cannot say that I have erer encountered such a combination of petty difficulties and annoyances. The road is, for the greater part, barely wide enough to achit of one mule passing with its packs, the sides forming steep embankments, composed chiefly of rich clay, but, in many places, of large rocks, through which a passage had evidently been cut with great labor. But little of the country can be seen on either side, owing to the height of these embankments; but now and then the trareller obtains a glimpse of dense thickets, and occasionally of undulating hills, the summits of which are corered with a deep perennial green. The recent rains having poured in torrents down the steep siles of the road, every carity and crevice was filled with water and mud. Owing to the nature of the soil, and the constant traffic across the route from the time it was originally cut through, innumerable stones and flags had sunk considerably below the level of their original position; whilst a few had retained their places, as if to serre as stepping-stones to the traveller over the wet and mud. It is a task of incessant and wearying exertion, however, even for those who are mounted on mules, to aroid floundering into some of these pitfalls and quagmires at every step they make. 
"The mules themselves are, as I have alrearly stated, so morn-out, and broken-down, that it requires the utmost vigilance and care on the part of their riders to prevent them dropping, and precipitating them into the mire. In order to guard as much as possible against this contingency, whenever ladies travel this route, they are obliged to discard the side-saddle, and resort to a less feminine style of equitation. I overtook a party of about twenty persons on the road, amongst whorn was a married lady on her way to the States; and I watched her rather curiously, to observe how she got over the difficulties that beset her. Being fortified with that article of male attire, the figurative possession of which is said to denote domestic ascendency, she thought it incumbent upon her, I suppose, to display all the courage and nerve that should properly be encased in it. Sereral times, when I fancied that both she and her mule were on the point of being capsized, she recovered herself with admirable presence of mind, and seemed to enjoy the risk exceedingly.

"As to myself, I floundered on as well as I could with a mule tottering beneath me from sheer exhaustion, and sinking every minute up to his knees in mud. It seemed to me that we were making little or no progress; and I became thoroughly tired and disheartened. I do not know any temptation, however powerful, that would again induce me to encounter the never-ending series of difficulties and annoyances that laid in wait for me at erery step; and I must candidly own, that even the force of female example, of which I had so merry a specimen before me, did not at all shame me into a less impatient endurance of them. 



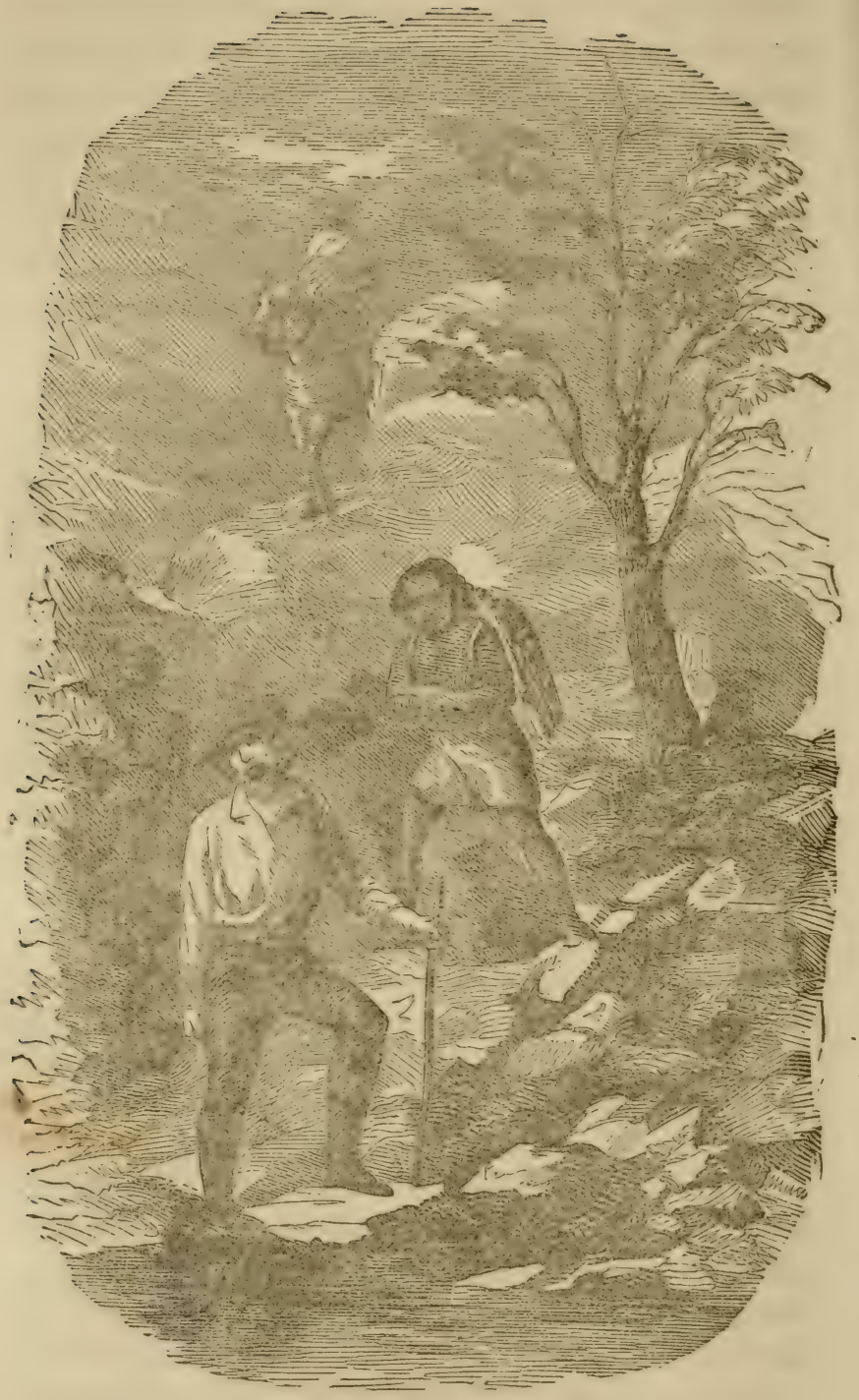

CROSSING THE ISTHMUS. 
"The negroes whom I met on their way to and from Panama excited my astonishment, from the amount of physical exertion which they seemed capable of undergoing. With their legs and feet bare, and nothing but a cloth around their loins, they carried enormous burdens on their backs, stepping from. stone to stone with wonderful strength and dexterity. These poor creatures must lead the most wretched and laborious of all the painful modes of existence to which their race is condemned; and not even long habit, or their peculiar physical construction, can divest it of its distressing character in the eyes of a stranger. They all bear, on their hard and wrinkled faces, the stamp of orertaxed strength; but they seemed content with their lot, and will, doubtless, regret the formation of a better route, as tending to depreciate the value of their services. Notwithstanding the toilsome and laborious nature of their occupations, however, the carriers of Panama are the hardiest and most muscular race to be seen here; for the rest of the population, both white and black, are of comparatively sickly and diminutive appearance.

"Moving somewhat like a ship in a storm, rising and sinking alternately at stern and bow, surmounting first one huge stone, then a deep mud hole, then another stone, and then a small lake, my mule and myself at last reached Crucis in the evening, tho wholo distance traversed not being above trenty miles." * *

The town of Crucis is a place very similar to Gorgona, but not so large. The houses are built of cane and plastered with mud. No attention is given to arrangement, and but a small portion is so constructed

- Personal Adventures in California, by W. Redmond Ryan. 15 
as to bear any resemblance to a strect. The climate is unhealthy, and trarellers from the United States make as short a stay there as pocible. Poubtless, with the increase of trarel, the character of the town and its accommodations will improre; but the hoat and humidity of the atmosphere, particularly just after the rainy season, cause a great deal of injury to the health of people from the Urited Stries, and will prevent any considorable settlement of Anglo-Saxons in the tomn.

Panama, the terminus of the raricil and diffentt route across the Isthmus, is situated on the shore of an extensire and beautiful bay. It contains about cight thonsand inhalitants, most of whom are negroes. Being one of the old spanith towns, upon the decline of the Spenish power, the place fell into decay. The houses are generully of stone or briuk, two and threo stories in height, whitcmasherl or corered with a coat of plaster, and are invarialily surmounded by a balcony protected from sun and rain by the roois of the housc's extending orer them. The town is remularly arrangerl, the strait and namow streots intersecting each other at right angles. The subetutial chameter of the brillings as well as the evilences of neglect and decay, strike the traveller at the same time. A wall was built hy the Spaniarda, arouml the portion of the town nearest the lays, but at least one half of the population reside boynd its limis, and it is in a dilapidater state. A renorable. lecaycu, bit still impung cathertal: a crant plua, or upen common -a general chmactevistic of Gfmish buit towns; sercral churches, pretly in mins; the ruins of the College of Jesuits, which corer a large extent, and of two monasteries, of which the walls and bells alone 
remain; and the frowning walls and towers of the battery, fronting the bay, are the principal features of the town of Panama. Since the commencement of the emigration to California, a number of Americans have established hotels and eating-houses in the town, and good accommodations are, therefore, to be obtained by travellers.

The atmosplere at Panama is particularly injurious to people from the northern climes, and great carc must be taken by travellers during their stay at that place. It is best to aroid eating fruit altogether; but, if indulged in, it should he in rery inconsilerable quantities. Exposure to the millday sum is a frequent cause of sickness among the travellers, and should be avoided, as well as exposure to the rain. During the rainy season, the vomito is often prevalcnt amnng the inhalitants of Panama, and is generally a fatal disease; but there is a great deal less trarel across the Isthmus during that season, on account of the sickliness of the climate and the dificulties of the ronte. A sort of bilions furer and dysentery are the most common forms of discase amone travellers from the north; but both may be avoldel by proper care.

From Panama, steamships of superior size and accommolation, convey passengers to San Francisco. Starting from the front of the ciry, the beautiful bay, with its semi-circular shores skirten with green foliage and inclosed with high mountains, and the lofty islands of Flamingo, I'erico, Taboga, and others, present themselves to the riew. At the island of $\mathrm{Ta}$ boga, all the ressels that come into the bay obtain their supplies, ant the Pacific Mail Steamship Company have established their depot for coal, \&c., on its shores. After obtaining all the necessary supplies, 
the steamship moves out of the bay, rounding Point Mala. The royage upon the Pacific, with all its variety of incident and scenery, then commences. The principal annoyance of travellers is the almost intolerable heat of the sun and furnaces of the steamship united. Water-spouts and different species of whale are frequent sights. North of the Gulf of Tehuantepee, the steamer nears the land, and the bold mountain coast of Mexico breaks upon the view, and, at night, the passengers enjoy a view of the glaring light produced by the burning rolcano of Colima; though the volcano itself is but imperfectly seen, being at the distance of ninety miles fiom the ressel. Soon after this fades from the view, the islands off the town of San Blas appear, and an immense white rock, isolated from the sca, serring as a lighthouse to ships steering for the port. At San Blas, the steamships remain some time, to obtain supplics of coal, fresh fruits, and provisions. These indispensables having been procured, the ressel proceeds upon her royage. Cape Corientes next appears, and, soon afterwards, the entrance to the Gulf of California is approached; and then, Cape San Lucas, the extreme southern point of California, with its mountains and rocky shores, is hailed by the traveller as the first portion of the "promised land" that greets his sight. Passing along the western coast of the peninsula, the island and bay of Magdalena appear, with shores three or four thousand feet abore the sea. Next, the towering ridges of Cerros Isles are passed, and the bold, rocky shores of the peninsula are in continual view. The change of the temperature of the air is generally keenly felt by those who do not take care to provide against it. Within a few days after leaving Panama, 
the thermometer falls from $95^{\circ}$ to $55^{\circ}$, and such a change must have an injurious effect, if additional clothing is not put on to meet it.

The first portion of Lpper California, or the "Gollen Land," which presents itself to the royagers, is the Ceronados, two high, round-topped rocks off the port of San Diego. Then the beautiful, semicircular harbor is enterel, and if wanting, supplies are obtained from the town. From the harbor of San Dicro, the ressel proceeds along the coast of California, and the towering peaks of the coast range of mountains, engage the attention. The high promontory of St. Vineent is passed, and then the open bay of Monterey is entered, and passengers are either let off the steamer or taken aboard as necessity may occasion. From Minterey the stcamer keeps along the coast, and mountainous shores alone meet the view, until tho royagers come in sight of the Farallones, two large detached rocks at the southern side of the entrance to the bay of San Francisco. Then the Golden Gate, as the strait or entrance is called, is entered by the steamer, and the perpendicular cliffs and hills upon each shore afford matter for wonder. The strait is about three miles long, and from one to two miles broad. As the ressel reaches its terminus, the great bay of San Francisco opens to the riew, looking like a miniature ocean. Bird Island, Wood Island, Angel Island, with the beautiful little bay of Sancelito, successively meet the gaze, and rery suon the steamer is anchored, having roached her destination. Such is the Isthmus route to the "gold region." It is the shortest route, or the one which occupies the least time in traversing, presents great 
variety, and upon the whole, its beauties and pleasures outnumber the difficulties and annoyances.

\section{THE OVERLAND ROUTE.}

WE now proceed to give the general character and direction of that which is considered the best land route to California, and which is the most travelled by emigrants. The principal adrantage possessed by this route may be stated in a few words. It is the shortest route to the bay of San Francisco and the gold region. The Indians upon the route are friendly and very few acts of hostility have been committed. The trail is plain and good where there are no physica; obstructions. To these must be added the certainty of the emigrants reaching their place of destination, in good season; which will not exist, if new and unexplored routes are attempted. The greatest calamities and sufferings have been endured by those who hare either taken an entirely different route, or deviated from the line which we will describe. Advice concerning the time of starting, preparations, \&c., will be interspersed in the description.

The starting point, and the general rendezrous for emigrants, is the town of Independence, Missouri, situated about six miles from the Missouri River, on the south side of it. This town has been, for many years, the principal outfitting point for the Santa Fe traders, and contains about two thousand inhabitants. Emigrants should be at the starting place by the 20 th of April, and start upon their journey as soon thereafter as the grass will permit. The outfit of companies of emigrants would be too tedious to mention, and as it varies considerably, from differences of means and taste, a description would hardly be accurate. But 
there are ccrtain things which are indispensable to those who take this route, and these we will mention. With respect to wagons and teams, the lightest wagon that can be constructed of sufficient strength to carry 2,500 pounds weight, is the vehicle most desirable. This can be drawn by three or four yokes of oxen, or six mules; oxen are usually employed for this purpose. Pack mules can only be employed by parties of men; but the journey can he made in great doal less time with mules than with oxen. The provisions taken by the companies, consist mainly of flour, hacon, coffee, and sugar; besides these indispensables, there is rice, crackers, salt, pepper, and other luxuries of light weight. As to the quantity necessary, that may be determined by considering the length of the route and the arerage number of miles which the emigrants travel per day. From Independence to tho first settlement in California, which is near the gold region, it is about two thousand and fifty miles-to San Francisco, 2,2n0 miles. Oxen tenms travel about fifteen miles per day unon an arerage. At that rate, it would require one hundred and thirty-one days to reach the first set.tlement in California. Allowance should be made for stoppages by accident. Every man should be provided with a good rifle, a pair of pistols, with a quantity of ammunition, and a bowie knife and hatchet, in his belt. A set of carpenter's tools is also necessary.

Starting from Independence, and travelling a few miles over a gooul roal, the first prairic opens upon the view. This is called the Blue Prairie, and presents a surface undulating and clothed with rich ve:dure. In crossing this prairie, riolent storms often overtake the emigrants, and to those who have not been accustomed to it, the scene during the storm is 
terrifically grand. Fourteen miles travel upon the prairie brings the emigrants to the "Blue Creek," which is fordable, except after a heary rain. Fording the creek and crossing the timbered bottom of the stream, another magnificent prairie is entered, which is beyond the Missouri line, and within the Indian territory. Sixteen miles travel over this beautiful plain brings the emigrant to Indian Creek, the banks of which usually serve for a place of encampment. The prairie offers the best pasturage for cattle; but constant watching is necessary to keep them from straying away and returning to the settlements. From Indian Creek, the emigrants proceed across the prairic, along the Santa Fe trail, for about fifteen miles, and then leave it, turning off to the right hand. Crossing several deep ravines, which are very difficult of passage in rainy weather, the emigrants arrive on the banks of the Werkarusa Creek. This is another favorite place of encampment, groves of trees being on each side of it. From this creek, the route is over the high-rolling prairie, upon a smooth and hard trail. The want of water is the only annoyance that is experienced by the travellers, and a long day's journey is necessary to bring them to the nearest creel-a branch of the Kansas River. The banks of the creek are steep, and considerable toil is requisite to cross it.

The crossing of the Kansas River is the next difficulty to be met. There is a regular ferry about five miles from where the emigrants cross the tributary creek. At that place the river is never more than two hundred yards wide, even after heary rains. The wagons are placed in boats, owned by the Indians, and transported to the opposite shore for the sum of one dollar per load. The oxen and horses are com- 
pelled to swim across. Following the trail for about three miles, a place of encampment, on the banks of Soldier Creek, is reached. The soil in the neighborhood of the Kansas is luxuriantly prochctive, aud the most refreshing verdure meets the eye along the trails from that river to Soldier Creek. The route is then pursucer over a fat plain-boggy in some places-for sereral miles, till another creck is reached, the banks of which are steep, and this, as in other cases, make its erosing a matter of great toil. The trail then runs orer a hiph, undulating country, presenting every rariety of scenery, as far as Black Paint Creck, near which are two Kansas Indian villages. The Kansas are a friendly trihe, and if they wcre not, they are not powerful enough to attack largo parties of emigrants. They are somewhat disposed to pilfer whatever they can conreniently, and require close watching.

After crossing the creek, the trail is followed throngh a fertile valley, across IIt itricane C'reek, which is somewhat difficult of passage, and then orer an open and rolling prairie, broken by small branches and ravines. Many places, convenient for encamping, are to be found on the route, some of which have springs of pure colt water. Farther on, the ground becomes more broken, and Vermilion Creek, a large and rapil stream, is reached. Its banks are steep, and its fording rery toilsome and difficult. Between this creek and the Big Blue, there is neither wood nor water to be oltained, and therefore, it is customary for the emigrants to fill their casks at this place. The ground between the two streams, a distance of ten miles, is more broken than any upon the former part of the route, and on arriving at tho 
Big Blue, a steep descent is made to the low, bottom lands near the river. The usual width of the Big Blue is about a hundred yards, at which time alone it is fordable. It becomes much swollen by heary rains, and very rapid in its current.

Arising from the bottom of the Big Blue River, the emigrants are again upon the high and undulating prairie. Every variety of scenery is presented to the view, and springs of water, issuing from the cliffy banks of the small branches and ravines, and shaded by groves of trees offer many places for rest and refreshment. Fourteen miles from the Big Blue, one of its tributaries, exceedingly difficult to cross with large wagons and teams, is met with. After passing it, the trail runs over a smooth inclined plane for the distance of twolre miles, to another encamping place for emigrants, upon the banks of a small creek. From that creek there is a gradual ascent for the distance of about fourteen miles, and then a beautiful valley, through which flows a small stream, meets the eye of the wearied emigrants, and offers groves of oak to serve for places of rest. Then there is another gradual ascent, through a country which is more sandy and less fertile than any met with upon the former part of the route, for more than trrenty miles. The Little Blue is then reached, and the train continues along up the banks of the stream for the distance of about fifty miles; the road being dry and firm, except in a few ravines. The trail then diverges from the stream to the right, ascending over tho bluffs, into the high table land of the prairie, and continues to ascend gradually until the bluffs overlooking the valley of the Platte River, are reached. The soil along this part of the trail is sandy, and the grass 
rather scarce; but water can be obtained at sereral places.

The Platte River is about one hundred and fifty yards in brealth where the trail reaches it. The eurrent is sluggish and turbid, and the water is very shallow. 'The trail continues along the banks of the river, the course of which is nearly from west to east, and the road is all that could be wished for travelling. The bluffs which skirt the valley present considerable variety, and as the route is continued, they become more elerated and broken. The soil of the ralley becomes less fertile and the regetation is thin and short. After traversing the valley of the Platte for the distance of one hundred and thirty miles, the trail crosses the river and continues along the northern bank of the south fork for about twelve miles, when it diverges from the stream to pass orer the prairie to the north fork. The distance from the south to the north fork of the Platte, by the emigrant trail, is about twenty-two miles, without water. The country between the two streams is high and rolling. The soil is poor, the grass short, and no trees or shrubs are visible. The trail descends into the valley of the north fork of the Platte, through a pass known as Ash Hollow. There is but one steep or difficult place for wagons in the pass, and in the ralley will be found a spring of pure cool water. At this place, there is a sort of post office, where letters are left by emigrants, with requests that they shall be taken to the States by those who pass this way.

For sereral miles from Ash Hollow the trail passes orer a sandy soil, which is very soft, but which afterwards becomes firmer. The scenery then presents the aspect of barrenness and desolation. Sand and 
rocks are all that meet the view for many miles. The landscape then assumes a greener and more refreshing appearance, and groves of trees relieve the emigrants from pursuing their way any farther during the day. Farther on, the well-known landmark, called the "Chimney Rock," which can be scen at a great distance, is met by the emigrants. It is composed of soft rock, and is several hundred feet high. The scenery in the neighlourhood of the rock is very remarkable and picturesque. There are a number of rocky clevations which present the appearance of rast temples and pyramids, with domes and spires partially in ruins. Over a sandy soil, the trail is pursued for about twenty miles, the surrounding scenery being of the most sublime and singular character. Near a remarkable rocky conformation, called "Scott's Bluff," the trail leaves the river, and runs orer a smooth valley in the rear of the bluff. It there ascends to the top of the dividing ridge, from which the Rocky Mountains can be seen. Descending from the rilge, it passes over a barren country, broken by deep chasms and ravines, for about twelve miles, when Horse Creek is reached. From that creek, the trail is followed to the Platte River, where a place for encampment is found, though the grass is very indifferent. Continuing for several miles through a barren country, the trail is followed to "Fort Bernard," a small building, rudely constructed of $\operatorname{logs}$, used as a trading-post. Eight miles farther on, is Fort Laramie, or Fort John, as it is sometimes called. This fort has been the principal trading-post of the American Fur Company. It is situated in the Laramie Rirer, near its junction with the Platte, and is six hundred and seventy-two miles from Independence. 
The building is quadrangular, and is constructed of aclobé, or sun-dried bricks. Its walls are surmounted by watch-towers and its gate is defended by two brass swivels.

From Fort Laramie, the trail continues on through a broken country, to the Platte River, a distance of twenty miles. Crossing a small creek which cmpties into the Platte, it proceeds through the dry bed of one of its branches, over a deep sand for six or eight miles, and reaches the summit of a high ridge. From thence it descends into a narrow valley, through which flows a small strean of pure water. Another ridge of hills is then ascended, and a wild, desolate, but picturesque scene is presented to the riew. Numerous lofty mountain peaks, barren rocks, and a vast prospect of low conical hills are the principal features. Through a country, the principal features of which are of this description, the trail is followed, and the monotony of the journey is only relieved by an occasional stoppage at a refreshing spring of water. The trail gradually ascends towards the summit of the Rocky Mountains, and the country becomes more broken and sterile, till it reaches Bearer Creek, a tributary of the Platte. There the grass and water are good, and the wood is abundant. The country exhibits every indication of fertility upon the trail leading from Beaver Creek, and pure and limpid streams are frequent, until the Platte River is again struck and followed upon its solithern bank, for the distance of about eighteen miles. The river is then forded, and the trail ascends the ligh blufis overlooking the valley, and proceeds orer sereral miles of table-land till the valley of the Platte is again reached. At this point, the trail finally leares the Platte, and, 
ascending the bluifs on the right, passes orer an arid plain dirersified with immense piles of rocks, deep ravines and chasms, and presenting a wile-spread sterility and desolation, for the distance of forty miles. Water is to be obtained in very small quantities and at few places on this part of the trail, and, therefore a scarcity should be prorided for before learing the Platte. At the end of that distance, the trail descends into a small valley, where spring water can be obtained and some refreshing shade. Ascending from this ralley, the trail gradually ascends to the summit of a dividing ridge, from which a riew of the S'weetwater River Mountains can be obtained. Descending from the ridge, a small stream, the grassy banks of which serve for an encampment, is soon reached. Farther on is a well-known landmark among the mountains, ealled Independence Rock. It is an isolated elevation, composed of masses of rock, about one hundred feet in height, and a mile in circumference, standing near the northern bend of the Sweetwater River, and between the ranges of mountains which border the ralley of that stream.

The trail proceeds up the Sweetwater River, and passes a remarkable fissure in the Rocky Mountain wall, which is called the Devil's Gate. The fissure is about thirty feet in breadth, and the perpendicular walls on each side of the channel of the stream which flows through it, are nearly three hundred feet high. The trail leares the river about twelve miles from where it first strikes it, and then returns to it after trarersing about sixteen miles. It again diverges from the river and crosses a broken and arid plain, which presents but few signs of regetation. Passing through a gap between two ranges of granite mountains, the 
first view of the Wind River Mountains is obtained. The trail then proceeds through a narrow ralley several miles in length, the surface of which is white with an alkaline efflorescence, and then returns to the Sweetwater River. Continuing up the valley of the Sweetwater, occasionally leaving the bank of the stream and passing over the rolling and barren tablelands, it crosses two small creeks which present good places for encampment. Sereral miles farther on, the trail crosses the Sweetwater River, and then leaves it finally, making a gradual ascent to the South Pass of the Rocky Mountains, or the diriding ridge which scparate the waters of the Atlantic und Pacific.

After the summit of the ridge is reached, the trail passes two or three miles orer a level surface, and then deseends to the spring, well known to emigrants as the "Pacific Spring." The water from this spring is emptied into the Colorado River of the West, which river enpties into the Gulf of California. This Pacife Spring is two miles west of the South Pass, and nine hundred and eighty-three miles from Independence, Missouri.

From the Pacific Spring, the trail passes orer an arid, undulating plain, in a west-by-north course, for about twenty-eight miles, when the "Little Sandy" River, a branch of the Green or Colorado River, presents itself, and furnishes the first water after leaving Pacific Spring. From the Little Sandy River, the trail passes over a plain of white sand or clay, and within twelve miles reaches the Big Sandy River, and passes along it for about eighteen miles, and then strikes off and crosses the Green River, or Colorado of the West. This river is shallow and only about serenty yards broad. The trail then continues down 
the Green Rirer a short distance, and then, making a right angle, ascends the blufis bordering the valley of the stream, in nearly a west course. The country then becomes still more broken and barren, and the trail ascends gradually to the summit of a rilge, from which it descends to the banks of the Black Fork, a tributary of the Green River. This Black Fork is crossed several times upon the route, but is not more than sixty yards wide and is very shallow. The trail leares it to cut off the bends and then returns to it. The scenery along this part of the route is interesting, but the soil is frightfully sterile. Diverging from the stream the trail passes orer a barren plain with no vegetation upon it except the wild sage, so common

- even in the most sterile country, and then passes through a bottom of grass, offering a good place for an encampment.

Near this place is Fort Bridger, a small tradingpost established by a Mr. Bridger. The buildings are two or three rudely constructed $\log$ cabins, and they are situated in a handsome fertile bottom, on the banks of a small stream. This fort is about eleven hundred miles from Independence, Missouri. From Fort Bridger, many parties anxious to explore the country, take the route by way of the south end of the great Salt Lake. But the scarcity of water and the other difficulties encountered in crossing the sterile plains and the great Salt Desert should be sufficient to deter emigrants with families from taking that direction. Oxen could not travel fast enough from one wateringplace to another, and must necessarily perish from thirst. Besides, the route is but poorly defined, and may be wandered from very easily.

The trail of the old route, and the one taken by 
most of the emigrants, leares Fort Bridger, and pursues a north-westerly course, through the Bear River ralley, which it leaves at a remarkable landmark called Sheep Rock, and crossing a dividing ridge reaches Fort Hall, by the valley of the Portneaf River. This fort was established by the IIudson Bay Company, and it is the seat of a considerable tracle in furs with the Indians and trappers. From Fort IIall the trail contimes on till it reaches the valley of Mary's River. There a tolerably fertile soil and refreshing vegetation greets the eye of the trarelworn emigrant. The trail crosses the river five or six times in as many miles, in order to take adrantage of the narrow bottoms made by the windings of the stream. The bottom is skirted by very high ranges of mountains to where the trail leares it, and turning to the right ascends orer low, gravelly hills. Descending from the summit of a ridge of hills, it passes through a valley where good grass and water can be obtained-the valley containing several springs of pure cold water. Emerging from this valley through a narrow gap, the trail passes into another still more extensive, and pursues a snuth-westerly direction for about twenty miles, keeping near the margin of Mary's River. A succession of low hills are crossed, and another valley is reached. During the journey throngh these valleys, the emigrants are exposed to the fiery rays of the sun, and the hot winds from the desert are very oppressire. The trail then follows the course of the river in a direction nearly north-west, through ralleys, or plains of great extent, and mountainous defiles, occasionally following a bend of the river towards the south-west. The greater portion of these valleys is barren, but there are frequent fertile spots 
near the boiling springs. The only Indians met on this part of the rute are the diggers, and they do not possess the power to do much harm, if they cren were hostile; but they are friendly. The want of water is the principal annoyance.

Passing over the desolate valleys and hills that border Mary's River, the trail descends into a large circular basin, in which a place for encamping is found, but with little water. From this basin, it crosses some consilerable elerations and then a totally barren plain ten miles wille. Beyond this, water and grass of tolerable quality are soon found; and there, if possible, a supply should be obtained sufficient to last for a long day's journey. Pounding the base of a mountain, the trail takes a south-rest course, across a totally barren plain. No sign of the river, or the existence of any water is exhibited. Near the southern edge of the plain, which is twenty miles in extent, some pools of standing water are found, and the place is known as the "Sink of Mary's Iiver." From these pools to the Truckec, or Salmon Trout River, the distance is forty-fire miles. The trail is followed over the hills of ashy earth, in which the mules often sink to their bellies, and orer a ground destitute of any vegetation, except occasional clumps of wild sage. A ridge of mountains is then ascended by an easy inclined plain, and a view of the distant range of Sierra Nevada is obtained on reacling the summit. The intervening valley presents as barren a prospect as the country immediately preceding it. Descending into it, numerous boiling springs are found, which often serve to delude the thirsty emigrants. But by damming up the streams which flow from them, the wator may be cooled, and, although impregnated with 
salt, sulphur, and magnesia, it may quench the thirst. The phenomenon of mirage is frequently presented to the view of the cmigrants, and it very often assumes the appearance of things unknown to that desert region, such as lakes, cascades, and foaming and tumbling waters. About twelve miles from the springs, a ririge of sandy hills, running across the valley, is ascended, and then an elevated plain of about ten milcs in extent is crossed by the trail. Over this plain the travelling is very laborious-the sand being very deep. But at length the Truckee River is reached, and water, grass and trees, larger than any upon the former part of the route for five hundred miles preceding, greet the wearied and thirsty emigrant.

The Truckec River is about fifty fect in breadth with a shallow but rapid current of clcar water. The bottom land is exceedingly fertile, and game is sometimes to be obtained in its neighborhood. The trail crosses the Truckee rery frequently, in its winding course, but the country being agreeable, this is not considered toilsome by the emigrant, after traversing the barren plains in the vicinity of Mary's River. The course of the Truckee is nearly from the south-west to the north-east, and in some places it passes between very high mountains, affording scarcely room for travellers to pass. Sometimes the trail is followed through fertile valleys and then orer barren hills and rocky passes till the summit of a gap in the mountains is reached, and a pleasant valley opens to the view, offering a fine place for encampment. The trail then turns to the lcft, and proceeds in a southerly direction, crossing the Truckee several times, until the Truckee Lake breaks upon the view. This small 
sheet of water is surrounded by lofty mountains, except upon the side where its outlet flows from it. The trail strikes the shore of the lake at its eastern end, and continues around its north-eastern side over a very difficult, boggy road. IIaving reached the upper end of the lakes, the trail leaves the shore on the right hand, ascends over some rocky hills, and, crossing some deep ravines and swampy ground, arrives at the base of the crest of the Sierra Nevada. Then comes the ascent of the steep pass-a work of diffculty and danger. The mules are compelled to leap from crag to crag, and, when heavily laden, are often precipitated backward in climbing the almost perpendicular rocks.

Having attained the summit of the pass, the view is inexpressibly grand and comprehensive. A mile journey upon the top of the mountain brings the traveller to a small lake, surrounded by good grass, which is often used as a place of encampment. Leaving the lake on the right hand, the trail descends over the rocky ground for a few miles, and then enters a beautiful valley about five miles long. Through this valley, which is called the Yuba valley, by the emigrants, flows the Yuba River, a tributary of the Feather River, and the scene of considerable gold digging and washing. This is the commencement of the gold region, and after their journey through the wilderness, here the emigrants greet the "promised land." From this point to Sacramento city, the great terminus of the overland emigration, it is about sixty miles; but the trading post of Yuba, Johnson's ranche, Vernon, and the other posts, offer convenient intermediate resting places.

We have thus sketched the general character of the 
principal overland route to California, and have followed the trail of the emigrant orer all the difficulties and obstacles which present themselves upon the route. That there are portions of the journey which are productive of considerable suffering, and which demand stout hearts and strong constitutions to meet them, is not to be doubted. But they are few compared with the dangers to be encountered by deviating from the particular trail whose course we have followed. The want of water is the principal source of annoyance towards the lake part of the route, but this occurs in few places. The longest distance to be travelled without finding water, is about forty-five miles-from the "Sink" of Mary's River to Truckee River, and this may be prepared for. It is a matter of great importance, that the delay upon the route should be as little as possible. Great suffering and many deaths have been caused by delaying too long at different camping places. It should be made an urgent duty to get over as much ground every day as possible, and to lieep in the old trail.

The overland route which we have sketched, and the route by way of Chagres and Panama, are the two routes by which most of the California emigrations had proceeded; but there are others projected, and some have been followed. Many persons have proceeded to California through Mexico; but the difficulty and delay in the matter of passports, and the opposition of the Mexicans to armed parties of another country passing their territory, must prore weighty objections to any such route. Another has been projected, and will probably be opened. It is a route across the territory of Nicaragua, in Central America. This will be the shortest and most convenient route to the gold 
region, and will absorb the greater portion of the travel thither; but the overland route will always be taken by those who have been accustomed to a country life, or have a thirst for adrenture. It presents the greatest variety of scenery-some of it of a character not to be scen elsewhere; and affords opportunities for studying nature in all her visible forms; and, though attended with toils and dangers, which will daunt the feeble, it possesses the strongest attractions for the lovers of variety, and the hardy adventurer who has confidence in his own powers of endurance.

\section{CHAPTER XII.}

\section{RECENT EVENTS.}

Beurevisg that every event which in any way affects the interests or welfare of California is important to those who have watched her progress and have been astonished at her rapid rise, we will in this and a subsequent chapter, bring the narrative up to the time of issuing this work.

The city of San Francisco, in the midst of her progress and prosperity, has been twice visited by the destroying element of fire. The first calamity of this kind occurred on the morning of the 25th of December, 1849. The fire consumed all that portion of the city on and near the plaza, involving a loss, at California prices, of over a million of dollars. Fortunately, 
it was the rainy scason. If the fire had occurred during the dry seasen, and the preralence of the furious gales, the whole city, composed, as it was, of canvas tents and wooden houses, must have been destroyed. The event did not matcrially affect the progress of the city; for the bumt district was entirely rebuilt within twenty days.

The second greut fire oreumes? on the night of the 4th of May, 1850. It broke out in the Unitel States Hotel, sitnated on the plama, or Portsmouth Srqurethe rery heart of the city. The flames som spread to the ardjoining buildings, and soveral of the principal hotels were destroyed. Nothing could stmp the progress of the fire but the tearing thwn of a whole block of houses on one of the strcets leading from tho Square. Fire entire blocks of the buriness portion of the city were destroyel-involving a loss of about a million of dollars. To sh w the amount of enterprise and energy cxisting in Sun Francisco, no better opportunity is afforlul than to louk at the state of things in that city, ton days after the fire. We extract from the Alta Californiun of the 15th of May, the following remarks:

"The Buraxed Distric".-Intimately as wo are acquainted with the predominant spirit of energy and enterprise of our city, we have alnost wondered at the rapidity with which the bumed district j.s locing again huilt up. It exceeds the speed with which the work was accomplished after the December fire. Alrearly, in Portsmouth Syuarc, the Bella Unim and St. Cliarles, houses of public resort, are opened and hourly thronged. In Washirgton Street, two dry goouls stores, 'La Amarilla' and Juan C'ma's, are opened and stocked, and on both sides of the way 
buildings are nearly completed, and will be ready for occupation by the latter end of this week. In fact, the ruins are more than half covered over, and except that the new edifices are not of so elegant a character or so substantially built, eren, as previously, they will present a handsome appearance.

"The fact of the business season having now fairly commenced, and the necessity of being alive to take advantage of it, has materially accelerated operations. The present busy hum created by the industrious mechanic, will soon give way to the usual activity and bustle of mercantile trade, and ere the departure of the next steamer a casual observer would be scarcely able to realize the devastation of the 4 th inst. Notwithstanding the immense amount of property destroyed, which was not at all over-estimated, business has not been so generally depressed, even momentarily, as it was feared and anticipated. Our community hare risen again to the surface of the waters with cork-like buoyancy, and the sad and gloomy faces of the carly part of last weck have brightened by the prosperous hopes anticipated in the future. Never was calamity taken with more fortitude and philosophy than in this city. And if to win success is but to deserve, then those who have suffered will meet with their just reward. Nil desperandum seems to be the popular motto, amalgamated with the David Crocket principle, enlarged and improred. We are satisfied that notning can retard or check the prosperity, rapid growth, advancement and importance of this, the principal city and seaport of the Pacific coast. Vive San Francisco!"

The annexed extract from the Message of the Mayor of San Francisco gives an idea of the quantity of 
disease and destitution in that city. No doubt San Francisco is the grand receptacle for all who become diseased in any way at the mines or other places in the interior; and this may serve to account for the extraordinary statements contained in the Message-

"During the last nine months, an expense of eighty thousand dollars has been incurred for the support of the sick and destitute, who have becn thrown penniless upon our shores, and found friendless and homeless in our streets, and for the burial of those who have died without sufficient means to defray tho expenses of interment. If these enormous expenditures are continued, (and it is evident from the rapid growth of the population, that they must scriously increase, unless some new system is adopted, it will readily be perceived that a very large portion of the revenue of the city will be absorbed in defraying the expenses of the hospital department alone. Something therefore must specdily be dono to remedy this great drain upon the public purse."

As an indication of the rast increase of the commerce of San Francisco, it is stated that, in six days in the month of May, 1850, there arrived at that port serenty-six resscls, freighted with cargoes to find $a$ market there. Several large steamboats hare been put upon the Sacramento and the Bay of San Francisco, and they are reaping extraordinary profits. The trip from San Francisco to Sacramento City was, a few years ago, a work of some days, but it is now performed in less than nine hours.

The reports from the mines continue to be of the most farorable character. Gold has been discovered upon Trinity River, about two hundred miles north of Sacramento City, and the digging has proved to be 
equal to that of any of the other placers. The mouth of the river, which empties into Trinity Bay, has been surveyed, and, being considcred a rery good harbor, a town has been projected, to be situated upon the shore at the mouth of the river. Rich diggings have been opened near Mariposa, and on one occasion, a mass of gold and quartz, weighing fifty pounds, was taken from them, and sold for sixteen hundred dollars. Several important discoveries have been made on the Mokulumne River. Out of one hole, three men, in two days, took the sum of four thousand dollars. It is thought that more bullion will be obtained during the dry season of the present year, 1850, than has been received since the commencement of the gold-digging. This scems to falsify the predictions of some persons, that the gold region would be speedily exhausted.

The following is an account of some bloody transactions upon the North Fork of the American River. We extract it from the Pacific News of May 15th, 1850:-

"About two weeks ago, a party of Indians came stealthily upon a few miners who were sleeping after their work was orer in their tents on the North Fork, some twenty miles above Auburn. Before the Indians sare any warning to the whites of their presence, they lilled two, wounded another, and then succeeded in making their escape. On Friday of last weck, a trader, who was trarelling with his team, was surrounded by Indians when about fifteen miles abore Auburn. The arrows fiom their bows took effect upon his person, and he only sared lis life by a precipitous flight. They carried off his coat which he left in his wagon, with $\$ 600$ worth of gold dust in the pocket. They also robbed his wagon of several valu- 
able articles. Upon receiving news of this attack at Auburn, a number of men set out on horseback, in pursuit of the Indians. They overtook them in a valley not far from Auburn, and found a large party of them drawn up to meet them. The Indians were armed with bows and arrows and had one gun. The whites attacked them, and soon put them to flight. The Indians left a considerable number of dead behind them, and it is supposed that they carried off many more. Two of the whites were wounded with the arrows of the Indians, but not fatally.

"It is believed by many of the miners that there are white men among the Indians, inciting them to hostilities. It is pretty certain that a German doctor has been leading them on in their attacks. A meeting was held at Auburn, last Monday evening, to raise a company of rolunteers for the purpose of scouring the country, and making war upon the Indians wherever found, so long as they maintain a hostile position, and a number of men were enrolled."

A portion of the Indians of the eastern part of California have always manifested their hostility to the whites, and have taken numcrous occasions to wreak their rengeance upon those whom they consider the invaders of their country. But the pursuit of such a course will only hasten their own destruction. They are in no condition to contend with the whites, and their proper. course would be to conciliate those whom they cannot resist. The following account of an exterminating expedition against the Indians is from the Alta Californian of the first of June. To our thinking, the punishment far exceeded the offence, and the officer who gave the order for extermination, is culpable in a high degree. 
"We have received particulars of the recent slaughter of a large body of Clear Lake Indians by an expedition sent out against them from the United States garrisons at Sonoma and Benecia. The tribe that incurred this terrible punishment, comprises the natives of Sonoma and Napa valleys, and has maintained, in general undisturbed peaceful relations with the white settlers of that section of California. Last summer, however, a stubborn family Indian ofiered an indignity to the wife of one Kelsey, who had resided in the country some nine years, for which he was taken before a magistrate and sentenced to receive one hundred lashes. After this punishment, on the same day, we are informed Kelsey, songht the wretched offender, and laid him dead at his feet, shooting him in the presence of sereral gentlemen, who remonstrated with him on the barbarity of the decd. This man Kelsey was afterwards murdered, as was also a brother-inlaw, by the Indians of the neighborhood. Since then repeated acts of violence have been visited upon the natires, and our readers will remember the accounts which we published a few months since, of outrages committed in Sonoma and Napa, by a party of desperate white men. The Indians were driven to the mountains, and subsequently made depredatory incursions upon their old masters, driving away cattle, and indulging their natural propensity to steal. Complaints were made,-doubtless the accounts of their conduct highly colored,- - to the garrisons of Benecia and Sonoma, and on the 1st of the month an expedition was fitted out against them, composed of a detachment of infantry, and a company of dragoons, under command of Lieutenant Davidson, (seventy-five in all,) 
with orders to proceed against the Clear Lake Indians, and exterminate, if possible, the tribe.

"The troops arrived in the ricinity of the lake, and came unexpectedly upon a body of Indians numbering between two and three hundred. They inmediately surrounded them, and as the Indians raised a shout of defiance and attempted escape, poured in a destructive fire indiscriminately upon men, umen, and chiluren. 'They fell,' says our informant, 'as grass before the sweep of the scythe.' Little or no resistance was encountered, and the work of butchery was of short duration. The shrieks of the slaughtered victims dieal away, the roar of muskets then ceased, and stretched lifeless mion the sod of their native valley wore the bleeding bodies of these Indiansnor sex, nor age was spared; it was the order of extermination fearfully obcyed. The troops returned to the stations, and yuiet is for the present restored."

Here is the account of more Indian troubles.

"Fight with tile Sacramexto Ixdiaxs.-TreaTT.-In consequence of depredations of the Indians of the Sacramento valley and outrages committed by them, General Thomas J. Green, 1st Division, State Militia, orlereil out two companies of Mounted Tolnnteers, under command of Captain Allgiers and Captain Charles Hoyt, and marched from Oro, on the 17th of May, in the direction of Deer Creck. On the same day Licutenant Bell, of Captain A.'s company, with ten men, encountered a large number of Indians, killed five, and took six prisoners.

"On the 18th the command scoured the country in the region of Deer Creek and Bear River. On the 19th, the trail to Colonel Holt's mill, where he was. 
murdered, was taken, the villages found to be deserted, and the white settlement abandoned.

"On the 20th, the Indians, two or three hundred strong, were discovered within two miles of Bear River, upon an elevated conical hill. An engagement took place, in which eleven Indians were killed and a number wounded. About fifty of the state volunteers were engaged. None were killed, but Captain Hoyt, Lieutenant Lewis, and Mr. Russell were wounded. Major Frederick Emory (brother of Major Emory, United States Topographical Engineers of the boundary Commission, ) was accidentally shot through the thigh with a rifle ball. He was aid-de-camp to General T. J. Green.

"On the 25th, the Indian Chiefs Weimer, Buckler, and Pooliel, came in, by permission, and entered into a treaty of peace between the three tribes, severally represented, and the State of California and Government of the United States. The treaty is sensible and comprehensive."

In the following, among other interesting intelligence, will be found an account of that which was expected long before it occurred-the resistance of some of the numerous body of foreign gold-seckers to the tax imposed upon them. The license tax is certainly a just one; but the foreigners presumed upon their number and strength, that they had power sufficient to resist its imposition. The easy exchtability of the Americans, upon any subject connected with their own soil is well known; and it is exceedingly strange that a serious collision did not take place. We extract from the Alta Californian, of June 1st, 1850.

The Alta Californian has letters from Stockton "to 
May 22d. On the Tuolumne, but little gold digging has been effected since last fall along the banks. The gold is under water, and preparations were making by companies to dam the streams to get at it. This work has been actively going on for five or six months. There is want of men at this kind of work, and eight or ten dollars a day is readily obtained. The diggings at Jamestown, Sonora, \&c., have been partially deserted on account of new diggings discovered at $\mathrm{Co}$ lumbia, three miles from Sonora, at the last accounts some two thousand persons had collected there, and town lots were selling at high prices.

Sonora is growing very rapidly, being in the centre of an extensive mining region. It is likely to be next to Stockton in size and importance. Discoreries of rich placers have been made in its vicinity lately; some of the richest holes at Columbia are thirty, forty, and fifty feet deep. A serious difficulty has broken out at Sonora. A number of foreigners refused to comply with the law taxing them for the privilege of working the mines. A time was fixed by the collector to summon a posse of American citizens to prevent them from working. The day previous to the time fixed, the foreigners paraded with guns, \&c., and reinforcements of Americans were sent for from the neighboring towns. A letter from Stockton, dated May 22d, adds:

"In the evening, the sheriff, Mr. Work, was accosted by a Mexican, who asked him if he was not an officer, or the officer who intended to enforce the payment of the license. On replying that he was, the Miexican made an attempt to stab him, when a person standing by, named Clark, with a single stroke of a bowie knife, nearly severed his head from his body. 
Thirty armed Americans soon arrived from Mormon Gulch, and the whole American population were on the alert all night.

"At last accounts there were two or three hundred Americans at Sonora, under arms, and others were hourly arriving. On Monday the excitement had somewhat abated. Hundreds of the Mexicans and Chileans were packing up and leaving for Stockton. Many of them disclaimed having had any intention of resorting to arms, and all were evidently more or less frightened at the aspect of affairs. It appears that the Mexicans who took part in the disturbance, were led on by some hot-headed Frenchman, lately arrived from France, of the Red Republican order. They found, however, that the majority of the Spaniards were not disposed to join them, and it is supposed that the whole affirir will blow over without any very serious consequences. The affair will probably be a severe blow to business, for the present, in Sonora."

The Stockton Times has a letter from Sonora, giving the details of this difficulty. The foreigners said they were willing to pay four or five dollars per month, but that the amount demanded was utterly beyond their power to pay. They made this statement at an interview with the Governor. The letter goes on as follows :

"During the discussion, an American who wished to get out of the crowd, began elbowing his way from the place where he stood, when a Mexican or Chilian, in front of him, drew a pistol. In a moment a dozen revolvers were out, and a precipitate retreat was made by the foreigners. No shot was fired, but the Mexi- 
cans were alarmed, and the town was cleared in five minutes. Our peace now seemed threatened by about five thousand men outside, and no inconsiderable alarm was created in town. The citizens armed themselves, and expresses were sent to Mormon Creek and Sullivan's Diggings, from which places about five hundred well armed Americans arrived, and marched through the streets with guns and rifles on their shoulders. The demonstration was sufficient; the crowds in the ricinity soon dispersed, and quiet was restored. The only thing to be feared, is the misguided zeal of our own citizens, who although generally sympathizing with the discontent occasioned by the unjust tax, are incensed that the foreigners should presume to take the law into their own hands, and may not be willing to allow the affair to rest where it is.

A serious affray took place this afternoon, in which a Mexican was seriously wounded. A man was noticed parading the streets with two or three pistols and a knife in his belt; the man was intoxicated, and the sheriff arrested him, or rather took his arms from him. While in the act, a Mexican came up behind and made a stab at the officer with a large knife. The murderous intent was frustrated by a bystander, who, with a bowie knife, struck the man, wounding him severely. Mr. Work, the sheriff, was happily untouched.

This state of affairs, if allowed to last, will ruin the prosperity of the whole southern mines, and your own town of Stockton will be the first to suffer thereby.

Monday, May 20.-A guard was kept up all last 
night, but every thing was quiet, and as I said yesterday, I believe the danger, if any was to be apprehended, had passed away. But the excitable feelings of the hundreds of Americans now under arms had to be indulged, and hearing that a camp, mostly composed of foreigners, situated about seven miles from Sonora, had mounted Mexican, Chilian, and French flags, (what truth there is in the report, I know not,) they have started out this morning to avenge the insult, and chastise the temerity of the "greasers" and "outsiders." I sincerely trust there will be good sense enough in the party to refrain from wanton aggression.

Gov. Burnett has sent Hon. John Bidrell and Judge H. A. Schoolcraft in charge of the block of stone contributed by California to the Washington Monument. It is thus described:

"This block of gold-bearing quartz, is from the Mariposa diggings, near Fremont's mines, and weighs about one hundred and twenty-five pounds. In shape it is irregular, approaching a square, its sides varying from eighteen to twerty inches in length. It averages in thickness nine inches-across its face diagonally it is twenty-one inches by measurcment. Very little gold is perceptible to the naked eye, but it is estimated to contain about eighty dollars worth."

Since the above events were recorded, another most disastrous fire has occurred in the city of San Francisco. It broke out in the Sacramento House, situated in the wealthiest portion of the city, on the 17 th of June, 1850, at eight o'clock, A. M., and in the short space of three hours, about two-thirds of the wealthiest district was consumed. The shipping in the harbor 
was only sared by the greatest exertion. The entire loss is estimated at from three to four millions of dollars. This event occurring so soon after the previous fire, has had a depressing and gloomy effect upon the business operations, not only of San Francisco, but of Sacramento City also. Many of the heaviest trading houses have been entirely ruined; and others brought to the verge of it. Sereral individuals, including the Mayor of the eity, distinguished themselves by their noble and generous exertions to arrest the progress of the fire and save property.

The emigration to California by way of the overland route is six times as great during the present year as it was in 1849. The last company left Council Bluffs, on the 15th of June. They brought up the rear of near four thousand wagons, ten or twelve thousand persons, and about twenty thousanil head of horses and cattle. The continued success of the golddiggers and the extraordinary prospect in regard to the quantity that will be obtained during the mining season of 1850 , serves to keep up the excitement and to allure the emigrant to the golden land.

There is a prospect that the seat of government of California will be removed from San José to the proposed new city of Vallejo, about twenty miles abore San Francisco, near the Straits of Carquinez, and at the junction of the Napa and San Pablo Bays. The new city has alrealy been surveyed, and a company of influential capitalists organized, with the determination to "go ahead," whether the capital is or is not e tallished at this point. The site no doubt presents many adrantages for a large commercial city, not possessed by San Francisco. The distance from 
the "Golden Gates," (as the entrance from the Pacific to the succession of bays connected with the harbor of San Francisco is termed) is about the same as San Francisco. The harbor is one of the safest and most commodious in the world, and the commissioners appointed by the general government to make surveys and decide upon the best location, have to recommend Mare's Island, half a mile from Vallejo, as the naval depot of the United States in California. The climate of Vallejo is delightful, and the place is never subjected to those strong and cold northerly winds which render San Francisco so disagreeable as a residence and so dangerous as a commercial city. There is plenty of marble for building purposes in the immediate vicinity of Vallejo, and plenty of limestone at a convenient distance, and easily obtainable. The new city will command a most beautiful view of San Pablo Bay and of the country adjacent, and the Napa valley (through which the Napa Rirer flows, and near the mouth of which the city is located,) and the Sonoma valley in the vicinity are among the most fertile in California. Near Vallejo are also mineral springs, possessing similar properties, and said to equal the celebrated Congress Springs at Saratoga. 


\section{CHAPTER XIII.}

THE MINERALOGICAL AND OTHER CHARACTERISTIYS OF GOLD, AND THE MODE OF DISTINGUISHING IT WHEN FOUND; TOGETHER WITH THE ASSAY, REDUCTION, AND REFINEMENT OF GOLD.

For the purpose of presenting all that is connected with that precious metal, that has built up a state within a few years, and of making the reader fully acquainted with all that is necessary for the goldseeker to know, we will now describe, in some detail, the natural history, character of gold, and the mode of determining its presence and value.

Gold invariably exhibits something of the peculiar yellow color which it is known to possess in a pure state; but this color is modified by various metals with which it may be mixed. Thus it may be described as having various shades of gold-yellow; occasionally approaching silver-white, occasionally resembling brass-yellow of every degree of intensity, and even verging on steel-gray in some specimens from South America.

The lustre of gold is highly metallic and shining, and cwing to the small amount of oxidation at its surface, it preserves its shining lustre even after long exposure in contact with other substances. Thus the shining particles are often seen in sand when the quantity is barely sufficient to repay the cost of working, notwithstanding the value of the metal. Even. 
however, if the surface is dull, the true color and appearance are easily restored by rubbing, and when polished it takes a very vivid lustre, which is preserved for a long time in the atmosphere.

Although in the division which has been introduced into gold-yellow, brass-yellow, and grayishyellow, native gold secms with some slight modifications to agree with the geological relations of its varieties, yet this mode of arrangement deserves little serious notice. The gold-yellow varieties comprise the specimens of the highest gold-yellow colors, though there are some among them which have rather a pale color; they include most of the crystals and of the imitative shapes, in fact the greater part of the species itself. The brass-yellow native gold is confined to some of the regular and imitative shapes of a pale color (which is generally called brass-yellow, and, as it is said, of a less specific gravity than the preceding one; but this does not seem to have ever been ascertained by direct experiment. The grayish-yellow native gold occurs only in those small flat grains which are mixed with the native platina, and possess a yellow color a little inclining to gray; they are said to have the greatest specific gravity of them all. The real foundation of this distribution seems to be the opinion that the first are the purest, the second mixed with a little silver, and the third with platina. It is not known whether the latter admixture really takes place, but it is certain that several varieties of gold-yellow native gold contain an admixture of silver.*

In color and lustre, inexperienced persons might mistake various substances for gold; these are chiefly

* Mohs' Mineralogy, by Haidinger, vol. ii. p. 438. 
iron and copper pyrites, but from them it may be readily distinguished, being softer than steel and very malleable; whereas iron pyrites is harder than steel, and copper pyrites is not malleable; for although the latter mineral yields casily to the point of a knife, it crumbles when we attempt to cut or hammer it, whereas gold may be separated in thin slices, or beaten out into thin plates by the hammer. There can thus be no possible difficulty in distinguishing these rarious minerals in a native state, even with nothing but an ordinary steel knife. From any other minerals, as mica, whose presence has also misled some persons, gold is easily known by very simple experiments with a pair of scales, or eren by careful washing with water, for gold being much heavicr than any other substance found with it (except platina and one or two extremely rare metals, ) will always fall first to the bottom, if shaken in water with mud, while mica will generally be the last material to fall. This is the case, howerer fine or few the particles of either mineral may be.

Gold therefore can be distinguished by its relative weight or specific gravity, and by its relative hardness, from other bodies which resemble it. It is described generally as soft, completely malleable and flexible, but more accurately as softer than iron, copper or silver, but harder than tin or lead. It is useful to know facts of this kind, as a simple experiment that can be made with instruments at hand, is often more valuable than a much more accurate cxamination requiring materials not immediately arailable. Thus if it is found that a specimen (perhaps a small scale or spangle) is readily scratched by silver, copper or iron, and scratches tin and lead, it may, if of the right 
color and sinking rapidly in water, be fairly assumed to be gold.

The weight of gold,' as of all substances, it is convenient to estimate relatively, and in comparison with the weight of an equal volume of water. The relative weight, or specific gravity, as it is called, of gold, is remarkably high, the lightest varieties being twelve times heavier than water, and pure gold nineteen times. This is expressed by saying that the specific gravity of native gold is $12-19$, and the number determined by comparing the weight of the mineral in water and air.

As the value of gold depends almost entirely on its specific gravity, and this test, therefore, is of the greatest practical importance, it will not be out of place if we here explain some very simple apparatus for the determination of this point.

If the specimen then is large enough to be suspended conveniently by a thread, weigh it first in air by a fine balance, expressing the result in grains, and taking care previously to remove dust or loosely adhering particles. Then suspend it by a horsehair from the scale-pan (it is convenient to have a hook attached to it for this purpose, ) and thus suspended, immerse it and re-weigh it in water, taking care that it is covered on all sides by at least half an inch of water, and carefully brushing off with a feather any bubbles of air that adhere to the surface. The results may then be noted as follows:-

Weight of substance in the air in grains . . .

Deduct weight of ditto in water

Difference

This result gives the weight of a bulk of water 
equal to that of the specimen, and by dividing the weight of the specimen in air by this number, the specific gravity is obtained.

Specile gravity- wreight af sulsatune in nir

If, howerer, the substance is in the form of fine sand, or very small lump, it is better, after weighing it carefully, to take a suall dry phial furnished with a stopier; comnterpoise this phinl aceurately in the woight-siale by shot on strips of learl, then fill it completely with pure watre taking care that no bubbles of air are left in, and weigh the quantity of water it contains: afierwards cmpty the bottle and dry it inside.

Next fill the borle alont two-thinds full of the powdor to be exnminet, woigh this am record the weight. Then fill the lonttle once more with water, taking care, as before, that all bubbles are expelled and none of the powder washed out. Once more weigh it.

We have then to molce the following calculation:

Weight of powder and water in grains $=$

Deduct weight of powder alone

Difference (weight of water left in bottle) $=$

Weight of bottle full of water in grains =

Weight of water left in bottle

Difference (weight of water displaced ky, and equil in bulk te, pomler) $\}=$

The specific srarity $=\frac{\text { weight of powder in air }}{\text { weight of water clisplaced. }}$

It may be useful to know the specific grarity of various substances at all resembling gold in weight $0 r^{\circ}$ 
appearance, and we therefore append the following short table. The specific gravity of water is assumed to be unity:-

\begin{tabular}{|c|c|}
\hline Osmium . . & \\
\hline Platinum . & $19 \frac{1}{2}-22$ not hammered. \\
\hline Iridium & $18 \frac{7}{10}$ \\
\hline Gold . . . & $15 \frac{3}{4}-19 \frac{1}{4} \cdot$ ditto \\
\hline Mercury. . & $13 \frac{1}{2}$ \\
\hline Palladium . & $11_{\frac{7}{10}}^{7}$ \\
\hline Lead . . & $11 \frac{1}{4}$ \\
\hline Rhodium & $10 \frac{3}{5}$ \\
\hline Silver. . . & 10 \\
\hline Copper. & $7 \frac{3}{4}-8$ \\
\hline Brass & 81 \\
\hline Lead ore (galena) & $7 \frac{1}{2}$ \\
\hline Copper pyrites & 5 \\
\hline Iron pyrites . & 4 \\
\hline Diamond & $3 \frac{1}{2}$ \\
\hline Sand & $2 \frac{s}{5}-3$ \\
\hline
\end{tabular}

By the help of this table the value of auriferous sand may also be in some degree estimated, since, as will be seen, the specific grarity of most of the sands is under 3 , while that of the most impure gold is 12 ; so that if the specifie gravity of the sands themselves, when expcrimented on, is much greater than that of ordinary sand, it is likely that the excess will be for the most part gold, in a district otherwise known to be auriferous: the greater the specific gravity, too, the greater probability there in, of this being the cause. It may also be worth while to mention here, that the specific gravity of those pepitas or lumps of gold which present a fine yellow color varies generally from $14 \frac{7}{10}$ to $18 \frac{8}{10}$; but when much paler they may range as low

* A very rough estimate of the value of specimens of native gold may be obtained by multiplying the specific gravity by 4 ; the result gives the value in shillings nearly. 
as $12 \frac{1}{2}$, which is that of a mineral called electrum, which will be described presently, and which is a mixture of silver and gold.

When a piece of gold is broken (which is not clone without difficulty-greater in proportion to its purity,) the fractured edges are very uneven and torn, exhibiting a peculiar fibrous appearance, known to mineralogists as "fine hackly." This fracture indicates that the minerul is twin asunder and not really broken, and is a proof of consilerable toughness.

The form in which gold is found is various. It is sometimes crystalline, in eight or twelve-sided regular figures, passing into cubes, but the crystals are generally small and rare. In case of such crystals being found, it is well worth knowing that they possess a value as mineral specimens fur bejond that of the gold which they contain.

More frequently the metal is found in lumps or grains, called by the Spaniards pepitas, rarying in size from that of a pin's head to masses weighing, as has been already mentioned, nearly one hundred pounds troy. The term pepita is only applied to grains of some magnitude, and the most common limits of size are from that of a small pin's head to that of a nut or gooseberry.

When much smaller and still rounded, they are called gold dust, and when flattened, scales or spangles. In nature, and when seen in veins of quartz, gold often occurs foliated, or in leafy expansions of extreme thinness, or in branchy (dendritic) forms, probably made up of minute crystals. It is in the form of very minute grains that the metal is generally disseminated through rocks and auriferous ores of various metals, and these are reduced according to 
circumstances in methods that will be alluded to in a future chapter. In pepitas and small grains it is carried down by streams and deposited in their beds, the pepitas being usually most abundant where there is reason to suppose considerable disintegration of the surface, and where the action of denuding causes to a great extent is evident. The coast of Africa and the rivers of Europe are examples of the former case, while the Sibcrian deposits and those of California would appear to belong to the latter.

The following are examples of the constituent parts of various specimens of gold obtained from different gold districts, and will form a useful guide for comparison.

Table showing the Composition of Native Gold.*

\begin{tabular}{|c|c|c|c|c|}
\hline Loeality. & Gold. & Silver. & Copper. & Iron. \\
\hline $\begin{array}{l}\text { Auriferous sand of Schabrowski, near Kathe- } \\
\text { rinenluurg, Siberia ( } 6 \text {. Tiose)............... }\end{array}$ & $95 \cdot 76$ & $0 \cdot 16$ & 0.35 & 0.05 \\
\hline Boruschka, near Nijuy-Tagilsk, Siberia (Rose)... & $94 \cdot 41$ & $5 \cdot 23$ & 0.39 & 0.04 \\
\hline Brazil (Dareet) $\ldots \ldots \ldots \ldots \ldots \ldots \ldots \ldots \ldots \ldots \ldots \ldots \ldots \ldots$ & $94 \cdot 00$ & 5.85 & & \\
\hline Beresovsk, Siberia (Rose) $\ldots \ldots \ldots \ldots \ldots \ldots \ldots \ldots$ & $93 \cdot 78$ & $5 \cdot 94$ & $0 \cdot 08$ & \\
\hline 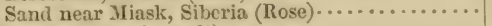 & $92 \cdot \pm 7$ & $7 \cdot 27$ & 0.06 & 0.08 \\
\hline Bogota (Boussingault) .............. & $92 \cdot 00$ & $8 \cdot 00$ & & \\
\hline Washings near Miask, Siberia (Tose). & $89 \cdot 35$ & $10 \cdot 65$ & & \\
\hline Gold of Senegal (Darcet)..$\ldots \ldots \ldots \ldots \ldots \ldots \ldots$ & $86 \cdot 97$ & $10 \cdot 53$ & & \\
\hline Auriferous sand, Nijny-Tagilsk, Siberia (Rose) .. & $83 \cdot 85$ & 16.15 & & \\
\hline Trinidad gold, (Boussingault) $\cdots \ldots \ldots \ldots \ldots \ldots$ & $82 \cdot 40$ & $17 \cdot 60$ & & \\
\hline Transylvanian gold (Ditto) $\ldots \ldots \ldots \ldots$ & $6+52$ & 85.49 & & \\
\hline Mine of Sinarowski in the A. & 60.08 & $38 \cdot 38$ & 0.33 & \\
\hline
\end{tabular}

The gold from California, according to the assay of Mr. Warwick of New York, yields 89.58 per cent. pure gold, and is therefore, about equal to that obtained from the washings of Miask (the richest district in Western Siberia, and that producing the largest pepitas,) and superior, as the assayer remarks, to the gold dust from Senegal.

There is a remarkable mixture of native gold with 
silver occasionally found in Siberia, and known under the name of electrum. Its color is pale brass-yellow, passing into silver-white. It occurs in small plates and imperfect clibes, and possesses many of the characters of gold, but it consists only of 64 per cent. of that metal, and 86 per cent. silver. It is at once known loy its low specific gravity, which does not exceed 12.

Oilher mixtures of gold are (1) a rhodium-gold found in Mexico, and containing 34 to 43 per cent. of molimm, haring a specifie gravity of $15 \frac{1}{2}-16 \cdot 8$, and a clear, dirty yellow color; and (2) a palladium-gold (enntaining 9.85 per cent. palladium, and $\frac{4}{4} 17$ per cent. silver) found in Brazil and elsewhere in South America, in small crystalline grains of pale yellow color. The auriferons ores of tellurium, including silver, hare hitherto only been found in Transylvania. Their color is stecl-gray, and they tarnish on exposureThe variety called graphic-golil, or graphic tellurinm, consists of about 60 per cont. of tellurium, 30 per cent. gold, and 10 per cent. silver, and is worked chiefly as an ore of gold. Another rariety, "yellow gold glance," yiclls somewhat less tellurimm, gold and silver, and as much as 20 per cent. of lead.

IIaving now explained at some length the more manifest characteristics of gold, namely, its color, hardness, and specific gravity, it is necessary, before explaining the mode of separating it from associated mincrals, that we should here give some account of the behavior of this metal under the blowpipe, and when exposed to simple cheinical tests. The assay of gold and its accurate analysis, we postpone for the present.

The method of blowpipe analysis, although exceedingly uscful, is not absolutely necessary in the case 
of gold, because of the many readicr ways of determining the metal, but it secms advisal)le to state the appearances presented. All the rarieties are readily fusible into a globule, which when the gold is pure, is unaltered by the continuance of the heat. In this respect it differs cntirely from iron and copper pyrites, which, on being exposed to the Hame, give off sulphur fumes and undergo considerable change. In the case of gold containing other metals, these, with the exception of silver, may generally be got rid of hy continuing the heat in the exterior flame with the addition of a little nitre. Before the oxy-hydrogen blowpipe, the metal is volatilized in the for $m$ of a purple oxide.

Gold is not acted on by any of the acids alone. When exposed to the mixture of nitric with hydrochloric acid (in the proportion of one part nitric to four of hydrochloric) ealled aqua regia, it dissolres without residue, the solution giving a purple precipitate with protochloride of tin, and a brown precipitate with protosulphate of iron. Electrum, the mixture of silver with gold above alluded to, is only partially soluble in aqua regia, giving a residue of chloride of silver. The solution is acted on by protosulphate of iron, as already explained.

The following simple mode of detecting attempts at imposition in gold dust is worthy of being recorded in this place.

Place a little gold dust in a glass tube or earthenware saucer, and pour nitric acid upon it; then hold the glass or sancer over a flame, or upon a few embers, until red flames (nitric vapors) arise; if it be pure gold, the liquid will not become discolored; but if pyrites or brass-filings should have been mixed 
with it, the acid will hecome turbid, green, and black, discharging lubbliles of gas. After the ebullition has ceased, the resilue shonld be washed with water, and acid again powed upon it, when the same effect may be oluservol, but in a less degree; and if the experiment be repented till all eflerrescence ceases, it will finally leave the gold dust pure.

\section{CIIPTER XIV.}

\section{ADDITIONAL RECENT EVENTS.}

Tre history of the lews of a State affionds the best idea of its social condition-present and prospective; for they are framerl from the neressity of circumstances and the demands of the inheritant: We mey, therefore, see the contition and the propress of the Californians in their legislative transactions.

The Californis Legistature aljoumet m $t$ lie $22 d$ Aprit. They lare pasecl a law creating a State assayer, until a mint be established in Culifornia. Among the one hundred and forty-three arts and joint resolutions passed, we nntice the following:

To incorporate the cities of Benecia, San Dieco, San Jose, Los Angeles, San Franciecn, Sonoma, and Santa Darbara, and is eneral act for the incorporation of cities; concerning the State revenue, otc, and its management; creating loans temporarily, appropriations, and other fiscal acts; relating to the appointment of pilots, regulating the duties of harbor masters, declaring certain rirers, etc., navigable, creating health 
officers for San Trancisco, creating a marine hospital, regulating quarantine at San Prancisco, providing for the inspection of stcamboats; subliviling the State into counties, establishing county scats and providing for the complete organization of all the counties; organizing the supreme court, proriling for the early publication of the laws, organizing district courts throughout the State, establishing a linmicipal court in San Franciseo, abolishing all laws in force in the State, except such as wore passed by this Legislature, adopting the common law, regulating the interest of money, public ferries, notaries public, jails and jailers, limited partnerships, roarls and highways, public elections, rolunteor compnies, wills, militia, lions of mechanics and others, descents and distributions, bills of exchnge aul promiseory notes, constables, coroners, guardians, fraululent conveyances and contracts, the rights of husband and wife, incorporation of colleges, marriages, anctioneers, goremment and protection of the Imlians, settlument of the cstates of deceased pursons, prececlings against debtor by attachmont; creating the oflice of State assaycr, molter ant refiner of gold, to regulate Bonatorial and $A \mathrm{~s}$ sombly distriets, presoribing the mode of maintaining and defending posecssory aetions on lambls belonging to the Unitel States; to prevent the importation of convicts; for the better regulation of the mines ant the government of forcign miners, the national Washington monument, pry of chaplain, the Pacife railway, and concerning grants of land by the deneral Goremment to commissioncl ollicers who served in the late war with Mexico.

IIcre we have all the machincry necessary for the full regulation of a large, commercial, agricultural, mant- 
facturing, and mining community. The session of the Legislature must have been laborious, indeed; but the nembers hare acquitted themselves of their arduous duties rapidly and well. One great measure adopted by the Lemislature was the substitution of the common law for the uncertain civil law which existed in California when ceded to the United States. The whole legal administration will now conform to that of most of the other States of the Union. The provisions in the Constitution for the purpose of education, hare been nol,ly carried out by an act for the incorporation of colleges.

Agriculture in California appears to be improving, and as it is getting to be as profitable as any thing else, it is attracting increased attention. Boxes of garden seeds which had cost nine dollars, have been sold for one hundred dollars, and seythes which cost three dollars, sold for forty-fire dollars. The sceds which were sent around Cape IIorn, were almost useless, while those which went orer the Isthmus, hermetically sealed, came up first. One man near San Jose, has made fifty thousand dollars by raising potatoes. What toil in digging and washing gold would be necessary to realize that amount!

Among the recent mining inciclents, the following is remarkable:-Last wintor, three men accidentally struck upon a rich deposit of gold, in a gulch about twelre miles from Knight's Ferry, on the Stanislaus River, and four or five miles ljack from it. They worked this rein with great success, managing to keep it a secret, until an Indian, wandering through the locality, discorered the secret, and communicated it to his tribe. The next day, sereral hundred Indians fell to work, with the same success; but as they spent 
their carnings in gambling and drinking at night, they incautiously let out the secret, and it spread among the rihites. The latter, without scruple, tonk possession of the ground, and set the Indians adrift. An alcalde was elected, the ground staked off, and allotted to the several claimants. This gulch, although rifled of its richest treasures, afforded good digging for a large number of persons, for some weeks, many crrrying away, when the water failed, a thousand dollars and upwards, as the result of their labors. The three discoverers of the gulch, took away with them about forty pounds of gold to each man, all scraped up in the short space of seven wecks.

Imitation lumps of goll hare been made and brought into circulation in Califomia. The State Assayer states that abore forty specimens hare been brought to his notice. They are generally in size from four to fire ounces to a pound in weight-quartz, and cvery thing else necessary to make them look right, properly intermixed.

It has been definitely settled that gold does exist in the ricinity of San Jose. Specimens have been taken to San Francisco.

Sereral artesian weils have been constructed at San Trancisco, since the second great fire, and it is thought that others will soon add to the comfort and convenience of the peonle of that city. The want of good water for drinking purposes, has been the most sericus objection to San Irancisco as a place of residence; and additional incentive to exertion in the matter is furnished by the constant apprehension of destructive fires.*

* The Alta Califormian, of the 1st of May, 1850, furnishes us with on interesting account of the origin and b.eaning of the names of 
Coal has been discovered in California, in various places, and is reported to abound in considerable quantities in the neighborhood of San Francisco. Every day developes some new wealth of this land of

places in the new State. Wc have elsewhere alluded to the name Calionia, as being derived fiom caliente and fornulla, two Spanish words, together signifying hot furnace.

Pueble de los Angeles-City of the Angels. So named from the fertility of the soil, the geniality of the climate, \&c.

San Dierro, Santa Barbara, San Luis Obispo, Santa Clara, Santa Cinu, San Francisco, were all originally Catholic missionary stations and were so named by the priests.

Monterey signities literally king of furests, and was so called in honor of Count Alonterey, as well as fiom the neighboring forest of massive pines and other trees.

Contra Costu, the nime of a county, simnifies opposite coast, from its being opposite San Francisco. Nount Diablo, which is in this county, was named from the following circumstance:

In 1806 a military expedition from San Francisco marched against the tribe "Bolgones," who were encamped at the font of the mount; the Indians were prepared to receive the expedition, and a hot engagement ensued in the large hollow fronting the western side of the motint. As the victory was about to be decided in lavor of the Indians, an unhnown personase, decorated with the most extraordinary plumage, and making divers movements, suddenly appeared near the combatanis. The Indians were victorious, and the incognitio (Puy) departed toward the inount. The leicated solciers, on ascertaining that the syrit went through the same ceremony dialy and at all hours, named the mount "Diablo," in allusion to its mystrious inhabitant, that continued thus to make his strange appearanec, until the tribe was subdued by the troojs in command of Lieutenant Gabricl Morasa, in a sceond campaign of the same year. In the aboriginal tonfue "Puy" simnifes "Evil Spirit;" in Spanish it means Diablo, and Devil in the Anglo-American language.

Culazerus siznifies skulls, at!d the creek thus styled was named from the fict of three thousand skulls having heen lowind lying on its banks by its early discoverers. They were the reminnts of a great battle between the Indians.

Tuolumme, which has been spelt so many diferent ways in the letters from California, is a curruption of the Indian word "talmalamme," a cluster of stone wigwams.

lifuripose means butterfly. The river was so named in 1 sor, by a hunting party of Caliornians, from the fact of their encampment there having been surrounded by myriads of most gorgenus butterilies.

Soleno was so named after a celebrated Catholic missionary.

Yulo is a corruption of the Indian word "Yoloy," and means a place abounding with rushes. 
treasure, and we regard the discovery of the abundance of coal as in the highest degree important to the residents of California. Even amid the news of the extraordinary yield of the gold region during the present year, 1850, when a single vessel, in one trip, brings $\$ 2,000,000$ worth of gold dust to the United States, we can pause to notice the discorery of the more useful substances.

The Trinity River and Iumboldt Harbor, in the north-western part of California, have lately become a resort for the superfluous population of the Sacramento and San Joaquin regions. The harbor is pronounced a very good one, and the discovery of abundance of gold on the branches of Trinity River, will, doubtless, contribute to the building of a large town upon its shores.

In the middle of June, there was much excitement in San Francisco, caused by the reported discovery of a gold lake, among the mountains between the South Fork of Feather River and the Yuba. One man was said to have got $\$ 7000$ in four days, and a party of ten Kanakas were reported to have got $\$ 75,000$ in a

Marin was so designated after a great Indian chief, who made war so desperately against the Spaniards.

Sonoma is an Indian word, signifying valley of the moon. The Indians so named the valley in which the present town of that title is situated.

Napa was the name of the Indian tribe who inhabited the valley of the same name.

Mendocino was so named after the first Viceroy of Mexico.

Yuba, a corruption of "uba," originally alluded to the immense quantities of vines which shaded the river.

Butte is a French word signifying hill, and was given by a party of hunters from the Hudson Bay Company to a range of high hills in the valley of the Sacramento. From thence the county is named. Coluse county was so called after an Indian tribe of which it was the name.

Shalta county is so styled after an Indian tribe also. 
week. A vast number of people were by this means attracted to the sources of the Feather and Iuba Rivers, and though they found the lake story a hoax of a vile character, they found tolerably fair diggings, which would console them for their disappointment.

The following extract from the Placer Times of the 17th of July, 1850, under the head of "Great Discorcries of Gold-Gold Lake," will afford the realer a lirely conception of the degree of excitement caused in California by erery new amouncement of a newly discorered locality abounding in gold:

"We were inclinerl to give only an average degree of credit to stories that liave reached us during the past few days, of the unprecedented richness which this locality has dereloped. A fow momerts pased in Marysrille on Saturday, convincoul us that there is much more show of reality in this last eurelec report, than usually attaches to the like. In a year's experience of local excitements from the same cause, we have seen none efual to what now prevails in that town. It has visited all the inhabitunts incliscriminately, lawyers, dioctors and judges, trarlers, tcamsters, mechunies and gamblers. Our readers know we are the last to justify the circulation of unfounded or exaggerated reports, but we leem it right to conceal nothing of what may prove (for anght that we can sce to the contrary) one of the most astounding discoreries in the modern history of digeings. The specimens brought into Marysville are of a value from $\$ 1600$ down. Ten ounces is reported as no unusual yicld to a panfull, and the first party of sixty, which started out under the guidance of one who hail returned successful, were assured that they would not get less than $\$ 500$ each per day. We were told that the previous 
morning two hundred had left the town with a full supply of provisions and four hundred mules. Those who could not go were hiring others in their stead. The length of the journey and the quantity of provisions required, there being no stores in the region, rcndered an outfit rather expensive. Mules and horses had doubled in value, and $\$ 400$ were considered no more than enough to furnish a proper start.

The distance to Gold Lake was first reported two hundred miles; the best informed, however, say that it is but little more than half of that. It lies at a very considerable elevation among the mountains that divide the waters of the South Fork of Feather from those of the north branch of the Yuba. The direction from Marysville is a little north of east. The story has of course spread ere this far and wide among the miners high up on the Feather and Yuba, and the spot will be as crowded as all other good places are, cre the tardy adventurer from this region could reach it. The region of the Gold Lake wonders is a new one, however, and lies between what are established to be diggings of unsurpassed richness. It is our belief that it is better for one who has got some initiation into the gold mysteries, (if there be any,) not to. be content in old ' used up' localities, but to push along to the great field yet unexplored; and that, though the search be long and laborious, the big lift is ultimately pretty sure for those who are patient and persevering.

The same paper of July 18th, contains additional particulars, having a tendency to add plausibility to the reports. Among other things, a man by the name of McLelland came into Marysville on the 17th, with $\$ 7000$, the result of four days' labor at Gold Lake. 
Whaterer may be the truth of the reports, there is no doulst of one thing - the whole population of Marysville and its vicinity have become infected by the news, and are taking up their march thitherwards in crowds.

The Transcript speaks rather doubtingly on the subject; it says-"The reports come as a general thing, through teamsters and other persons whose interest it is to give as farorable accounts as possible. The statements are very conflicting."

To this we may add the statement of a gentleman who reached this eity from Marysville, direct, on Tuesday night. The excitement, he says, is great; but no one could gire any definite information of the locality or of its productiveness. Iet all seemed to think there was no doubt in the matter, and as many as conld get away were starting, or getting ready to push for the new El Dorado. Upon his way down, on board the boat, he conversed with a man who professed to hare explored that region lately, although he did not claim to lnow where Gold Lake was. But between the North Fork of the Yuba and Feather Rivers, at the foot of the great chain of mountains, he reported a series of lakes of rarious dimensions, and " $t$ wo thousand people," prospecting all about. The snow was rery deep_"six fect" - and but little gold.

rhe following cxtract from the Placer Times, is the most positive information whin our knowledge.

On the arrival of the "Luwrenee," yesterday, from Marysrille, we receired more news of the Goll Lake excitement, now prevailing in those parts. It promises to spare no one. Many who would not be understood to have yieldel to it, seek, under rarious pretences, to get away-some pleading business in other quarters of the mines; others desiring the recrea- 
tion of a country jaunt. It is reporter that, up to Thursday last, two thousand persons had taken up their journey; that many who were working good claims, and had made considerable progress, were deserting them for the new discovery. Mules and horses were almost impossible to be obtained. A supply from this quarter was expected daily, and most anxiously awaited. Although the truth of the report rest on the authority of but two or three who lave returned from Gold Lake, yet but few are found who doubt their marvellous revelations. The first man who came into Marysville took out a party of forty as guide, on condition they paid him one hundred dollars each if his story was rerified, and offering his life as a forfeit for any deception.

"This party, it is understood, came near losing their way, from the difficulty the guide found in retracing his path, after the snow had melted. Fortunately, however, they encountered another man, who was on his way returning, and he showed the track. The second person has since left with a much larger party, who are to give him tro hundred dollars each, and the same forfeit is provided. The spot is described as very difficult of approach, and it is feared that many will lose their way. A party of ten Kanakas are reported to have wintered at Gold Lake, subsisting chicfly on the flesh of their animals. They are said to have taken out about $\$ 75,000$ the first week. The lake is not large, and, after the wet season ceases, has no outlet; at present, howerer, the water runs over the basin, and finds its way into the North Fork of Feather River. At a lower stage, it admits of easy drainage, and the undertaking is already projected. 
"Of course the most extravagant anticipations are founded on the result of this work, induced by the yield from the borders of the lake which have already been realized. The "placer" proper is very limited, and little encouragement is given as to the character of the surrounding country; indeed, it is probably entirely unexplored, as the region lies about as far up among the snows as the most adrenturous have yet penetrated."

The Yuba River is destined to be thoroughly rifled of its wealt?. Three miles alove the new town of Lina, a compran las turnel the river from its course, and male it run through a lateral slongh. Prospecting of the bed has proved very satisfactory, and the shares in the company's stock have eoll at a high rate.

As was apprehended, varions difficulties have occurred between the owners of lant at Sacramento City, and a large number of scruatters upon it. The ground was bought and surveyed, and the title to ownerslip was perfect. But the number of emigrants who arrire at Sicramento at particular scasons forees thom to eneamp outside of the regularly built town, and when thus encamped, they consider themselves as settlers, and are unwilling to give up posscssion of the ground. The power of the law has been called into requisition sereral times to eject these squatters.

The cmigrants to California ly way of the Great Salt Lake route have endured terrible harlships during the present year. The rigors of the season, and the want of water, have been but secondary matters. The Indians, always unfriendly, have been particularly hostile, and sereral battles between them and the emigrants hare taken place. In one of the battles, thirty Indians were killed, while the whites had several 
wounded, but none killed. It is supposed that the assailants belonged to the Utalı. The Salt Lake City is the great refuge of the belated emigrants upon that route, and the Mormons are hospitable to all who visit them for shelter, or for mere curiosity.

The great body of the emigrants continue to take the old route, which we have elsewhere described, and find that it is the safest and shortest of the land routes. Judging from the statements of the number of emigrants who have passed Fort Laramie this season, we should say, that the route could scarcely be called a wilderness, when it is impossible to travel thirty miles without meeting with partics and families of whites. Part of this tide of emigration will flow to Oregon, no doubt, on account of the fertile lạnds to be there obtained; but the golden land will get the bulk of it.

In a recent tour through the resion bordering on Noqueleme River, in California, a couple of gentlemen from Stockton, discovered a care or grotto of great extent. They found that it contained large quantities of stalactite, and saw eridences of gold. The Indians who accompanied the gentlemen vere horror stricken at their audacity, when they entered a cave which tradition said no man returned from alive. The skeleton of a human being was found at some distance from the opening.

An erent has occurred which will no doubt cxercise a great infuence on California affairs. This is the discovery of the existence of abundance of gold in Oregon territory. The discovery created great excitement through the various cities and towns of Oregon, and the northern towns of California. That which is exhibited, shows an entirely different charac- 
ter to any of that dug in the mines of California. It contains large quantities of platina, and is said to be of a richer character. The mines just discovered are situated about two hundred miles from Oreron City. The consequenees of this discovery may be easily apprehended. Oregon will secure a larger share of the emigration from the Atlantic States than she had befor', and her progress will be rapid, for her soil and climate render the country an attractire place of resirlence. But will the progress of California be less rapid in consequence of this? We think not. The united attractions of the two territories will operate for the benefit of both, and only tend to increase the quantity of emigration.

\section{CHAPTER. XV.}

A GENERAL VIEW OF CALIFORNIA AT THE PRESEXT TIMIS.

TE have followed the narrative of the erents in the history of California up to the present time. We have traced her progress from her first settlement up to the time when she appears as a sovereign republican State; and we have seen the effects of her rast metallic wealth working wonders in a short space of time. We have seen her towns before and after the gold discovery, and marked the contrast; and we have seen her territory become thickly peopled, and her resources developed in a space of time which other territories less farored, would require for an infancy. We have also considered her soil, climate, productions, and population, and exhibited each subject as fully as 
our information warranted. But in order to give a clear conception of the general character of California and her resources and capabilities, and to enable the reader to obtain an idea of the bright future to which she is destined, we have concluded to add another chapter upon the general state of things there at the present time.

California is now a Statc-in organization at least, if not in being a member of the Union. The country has become thoroughly American in its government and laws. A Constitution is adopted as a State organization, which bears the impress of enlightened sentiment and just principles. The most liberal provisions have been made in that instrument for the grand end of public education. The power and capability of the people to rule themselves has been recognized in the nuatter of electing nearly all the officers of the government-including the judges of the various courts over which the State has control. The Legislature, in the course of a laborious session, has abolished the old civil law which ruled the country under the Nexican gorernment, and continued after the acquisition of the territory by the United States, and have substituted the common law of England and many of the States in the Union. In taking this step, they were actuated by sound policy. Few of those who were subjected to be tried, or to have their suits decided by the rules of this civil code were aware of the nature of these rules; and from their crude and unintelligible character, it would have been a long time before they could have been fully or certainly informed. The old common law is that to whose rules they have conformed in the older States, and which is better suited to their habits and principles of action. 
But with her complete State oreanization, Callivina has applied for admission into the Enion, and from various causes, without reason, as we conccive, has not yet been admitted to her claim. This delay, continued through a long session of Congress, has somewhat irritated the Californians, who are anxiously watching the doings of Congress. The state of feeling on the subject is clearly stated in one of the California papers; and it is worthy of attention. We extract it.

"Shall Califorxia be Admited ?- We desire once more to state calmly and firmly the grievances under which the State of California labors, in order that Congress, in her hesitation, which may terminate in an open refusal to admit us as equal sharers in the bencfits, as we are of the burdens of the general gorernment, may not act in ignorance of the true state of feeling existing here upon a point so vital to our future.

"California feels that she has been made the sport of gambling politicians long enough. This is the universal sentiment of one hundred thousand citizens of this State, expecting daily reinforcements which will swell the number to an aggregate of two hundred and fifty thousand before the second scesion of the present Congress. She feels that such a mass of men, born under the flag of the Union, have a riglit to some of the privileges which they were taught to suppose it typified. She foels that she has no right to be taxed and not protected-to be taxed, and not represented, to be taxed, and nothing but taxed. Nothing else has been done for her. We hear of no Indian agent in the country. American citizens are slaughtered weckly if not daily by savages on our border. An agent of the Postoffice Department has been sent here, but his porrer to put into 
successful operation a thorough mail system, commensurate with the wants of the people, has been effectually crippled from the want of an appropriation to meet the necessary expenses. We are without admiralty courts; yet the interests of the commerce of the Pacific are centring in the Bay of San Francisco. We are paying millions into the treasury of the Enited States yearly. Our custom-house is thronged daily with captains and consignees of ressels, paying government dues, which erentually come from the pockets of the citizens of the whole State; yet there is hardly a possibility that one dollar in a thousand will ever be expended for our benefit.

"This state of things is unnatural-too much so for a quiet endurance, unless stern necessity is at the bottom. Were there any reason why we should be treated thus, we could patiently suffer on. But there is none. And now a sentiment is fast gaining ground here, that it is the intention of Congress-or a portion of Congress, to throw us back upon a territorial organization. It may not be amiss to state that California, under no circumstances, will give up her State organization. She has just escaped from the crudities and unintelligibilities of the Mexican code. Under it, she would still be laboring, had the action of Congress been awaited. Neither to this state of rassalage to institutions foreign to the habits and education of her citizens, nor to a second vassalage of territorial government under Congress, will she submit now. She knows her interests too well for this. If we are driven to take matters into our own keeping, the responsibility rests not upon us, neither should the odium, if any attaches. Should Congress ever come to its senses, and do what naked justice demanded months ago, California will ever be 
ready and proud to form one of the States of the Union; but it is asking too much that she should offer herself a willing sacrifice on the altar of demagogues."

This is strongly and firmly said; and we hope that it will exercise some influence on those to whose attention it is directed. Nothing can be more unjust in politics than taxation without a due compensation of protection and of law. There is scarcely any prospect, however, that California will be required to go back to a territorial organization. Such a request would be absurd in the highest degree, and none but ultras recommend it.

Whether California be admitted into the Union at the present session of Congress, or not, we may consider her Constitution and many of her laws necessary for carrying out the provisions of the Constitution, as fixed and operative. We have then, in a knowledge of their laws, a riew of the character of society in California, in many particulars, but there are others which require further observation. One feature strikes the observer at first glance. It is the variety of nation which marks the population of the principal cities of California. There may be seen the rapid, yet prudent Tankee, with a sharp eye to the main chance, and a ready comprehension of the consequences of a bargain or a speculation; the cool, slow, and heavy-moving Englishman, wishing to be sure of his game, and, therefore, late in grasping for it; the lively and sociable Frenchman, contrasting appearances and manners with things in Paris; the coarse-looking German, with a lively conception of the wealth of the country, and a decp consideration of the means of grasping a goodly share of it ; the half-Spanish native of California, with his love of indolence, and easy of satisfaction; the 
Chilian, with the ferocity and the cowardice of the descendants of the Spaniards, and loving fandangoes and riding horses, as intensely as the Californians; the Chinese, with dirty, but industrious habits, and the native Indians-a mean, degraded specimen of that noble race that once were lords of the American forests.

At the present time, it is a matter of doubt, whether the Americans or the foreigners predominate in the population of California. It is certain that the former have things pretty much their own way in the various cities and in the mines. But that may be from a want of unity of action among the foreigners. The habits and modes of life belonging to the Americans are generally prevalent in the cities; but in the smaller and older towns, the native Californians conduct cvery thing in the old Spanish mode. The difference between the society of Los Angeles and Sacramento City, is wide, and affords a good contrast between the restless, enterprising, utilitarian spirit of the Americans, and the indolent, pleasure-loving spirit of the Californians. With the Americans, in the cities where they are in the majority, business is the uppermost consideration upon all occasions, and profit and loss, and chances of obtaining a competency, the constant subject of thought. With the Californians, the enjoyment of the present, which alone is theirs, is at all times a matter of prime importance; and gambling, drinking, dancing, guitar-playing, and riding on horseback, are the principal sources of their pleasures. Which of these modes of passing array life is the most philosophical, we leave to the speculative. But it is apparent in California, that the energy of the American character is excrcising a great influence on the descendants of the Spaniards. Their spirit is 
infectious. In some of the towns upon the coast, one half of the Tuilaings are ocoupied by persons riho haro cmigrated from the Eustern States; and the contrast between their log and brick houses, and the adobe hotses of the Culifornians, is singular, and secus as if the old dead looking trunk of the tree law suddenily sent out new branches full of life and freshness.

All the rices conserment upon a lieterogencous population, suddenly thrown together and stimulated to an extraordinary degres of actirity, have fully cxhilsited themselves in Califomia. Nearly every body in the mining regions carrics deatly weapons of sune sort, and with the premptings of ararice, and the cxcitument of prosim, many shocking, secret murkers, and many open, rerengolul encounters are continually oecuring. The practice of carrying deadly woapons con only be abolished when a stronger fecling of seourity, inducel $\mathrm{ly}$ a confilence in the protection of the laws, shall take the place of constant dread. The mining population is of as mixed a character as that in the commerciul cities; and national jealousies will occur occasionally. The clation consequent upon succestul gold digging and speculating, leads to excess in drinking anl gambling, and these lead to frequent quarrels and deatly cincounters. The remedy for these things is only to be found in the reaction to which a few years will lead, when the power of the law shall be supreme throughout the gold region.

The principal thing which has contributed in some degree to influcnce the prospect and the labors of the miners, is the goremment tax upon the foreigners who wish to work upon the public lands in digging and washing gold. The tax is certainly a just one, 
but many are of opinion that it is too high. A lighter tax would more readily receire the assent of the mass of forcigners; but whether it is not just that they should pay a tax of eight dollars for every ounce of of gold they obtain from the land of others, is another question. The greater portion of the gold region belongs to the gorernment, and was paid for by the government. The people of the United States should, therefore, have the sole right to ccoupy it; and it is but just, that those people of foreign nations who wish to reap a profit from it either by digging gold or cultivating the ground, should pay for the use of it. The effect of the tax in, that those who must pay it, either must give up mining or work harder to reap sufficient profit. In either case, the country is benceited.

The mining region is constantly increasing in extent. The placers îrst worked stiil yicld a profit suffcient to rewarl the gold secker for his labor, and the frequent discovery of new ones by parties prospecting, keeps up the heat of excitoment. The region is constantly extending towarls the north. The ricinity of Trinity River is the most northern part of California where gold is obtaincl in any considerable quantity, and the source of the San Joaquin, is the most southern. The entire region embracel between theso two points is known to abound in the precious metal, and is traversed by the goll "prospecters." Of the gold obtained, a great quantity-a third, at least, remains in the comntry. Another is carried out of California by the foreigners, and the remainder is sent to the Atlantic States of the Union. This is but a rough estimate; but it seems warranted by the facts of the number of foreigners in the country, and the necessary current money of the residents. Cer- 
tain it is, that were we to judge of the quantity of gold obtained in California, by the amount received in the United States, we would fall far too short of the truth.

The growth of the commerce of California necessarily carries with it the growth of all those cities and towns which have any commercial advantages, or which are connecter with the rarious ports. Not only has San Francisco constantly in her harbor a tremendous flect of merchant ressels from all parts of the world, pouring into her lap the commodities necessary to a new country and a rapid building city, and Sacramento, the commerce of the mines continually passing through it, but all the towns along the coast have felt the impulse, and have become the seat of a traffic of some sort. San Diego, Santa Barbara, San Pedro, and Monterey, are all commercial ports, which have become the resort of those trader's who wish to escape the crowd of competitors to be met with at the more northern towns, and to have a pleasant place of residence besides. Los Angeles, twenty-five miles from the port of San Pedro is the centre of an extensive inland trade, and from its being a delightful place of resilience, will contribute to the building up of San Pedro in a greater degree than the commerce of San Pedro can influence it.

At present, San Francisco is a city of about thirty thousand inhabitants, and in spite of the repeated visitations of the calamity of destructive fire, it has suffered no stoppage in its rapid progress. On the contrary, these fires seem to give a new impulse to the energy and enterprise of its inhabitants, and, by impressing upon them the utility of building their houses and stores of the more substantial brick, to have 
been of permanent benefit. Like the water of a rapid river, which, meeting with a serious obstacle in its course, is checked for the moment and then, having gathered new strength, surmounts the barrier and springs forward with renewed energy, San Francisco has pursued her course. The late fire, decidedly the most disastrous the new city has experienced, produced for awhile a general stand in business. But the goaheadative principle was too strong for a continuance of a stagnation; and all the sufferers set about doing their utmost to retrieve their fortunes. Success must wait upon such persevering energy.

Sacramento City is fast treading upon the heels of her commercial sister city. Improvements are constantly being made to the appearance of the city and the comfort of its inhabitants. A levee is in course of construction, which, it is thought, will effectually protect the city from being flooded during the season of the rise of the river. The overland emigration of which Sacramento is the goal, contributes to swcll the population rapidly; and, during the rainy season, the greater portion of the population of the northern mines flock into the city for refuge till the digging season commences.

Stockton, Benicia, San José, and Sutter are each increasing the number of their residents and their trade very fast. The first is the depot of the southern mines; the second, the military and naval station, chosen by the government officers; the third is the capital of the State; the last is a thriving town, near Sacramento, but in a better situation.

One of the most interesting features of California is the number of the missions in various parts of the State. They are and will continue to be interesting, 
because of their age, and the self-denying and energetic lubors with which they are connected. They were the centres, established by a few Catholic priests, from which the rays of enlightenment and civilized enjoyment were spread to the native Indians of California. Each mission was a little principality, with many leagues of land attached, with some thousand head of cattle, and all the neighboring Indians subject to the control of the padre, and cultivating the land for their own and the padre's benefit. In 1800, these missions were sixteen in number, and three only liare been added sinee that time. They are named and located as follows:- San Rafael and San Francisco Solann, north of San Francisco Bay; Dolores, near San Francisco; Santa Clara and San José, near Pucblo San José; San Juan, Santa Cruz and Carmel, near Monterey; Soleclad, San Antonio, and San Miguel, in the ralley of Salina River; San Luis Obispo, La Purisima, Santa Inez, Santa Barbara, and San Buenarentura, near Santa Barbara ; San Gabricl and San Fernando, near Los Angeles; and San Luis Rey, San Juan Capistrano and San Diego, on the coast, south of Los Angeles.

Whe wealth and power of these missions have fled, and they are all, more or less, in a state of decay. The Indians who were prospering under the care of the priests have either taken refuge in the mountains or linger about the old mission buildings, in a degrarled and ignorant state. The immense quantity of land which was once attached to them has been taken from them from time to time, and now they but secm the ruins of former greatness. The beauty of the country surrounding those of the missions which are still existing, and the picturesque appearance of 
those which are in ruins make them well worthy a visit to the lover of the antiquated.

The usual attendant of the American enterprise, the printing press, has found its way to California, to contribute to the information and convenience of the people. Several papers are in extensive circulation in the cities and towns, and projects for others have been formed. The principal are the Alta Californian, the Pacific News, the Courier, and the Placer Times. The three first are published in San Francisco, and the last at Sacramento.

The want of facilities for transportation must be severely felt in the interior settlements of California. Steam ressels of the swiftest and most commodious character are the means of easy communication and transportation between San Francisco and the towns on Suisan Bay and the Sacramento, as far as Sacramento City. Communication by the same means will doubtless, soon be established between the different ports on the coast. But railroads and canals are requisites for increasing the social communication and drawing the people of all parts of the State more closely together. These, howerer, will not be long in demand, after the State has been admitted into the Union. The companios for such purposes will feel secure in their charter, and receive assistance from the government. There is nothing more efficacious in binding a people together and maintaining peace and harmony of action, than the mechanical facility of communication. The Atlantic States of the Union afford plentiful illustration and evidence of this assertion. Mark the differences of habit and sentiment in those States, where the means of intercourse between the inhabitants are comparatively few and far between. 
The interests of the different sections of a large Stato aro of course, dissimilar, and procluce the ridest separation of fecling and opinion, which cannot be harmonized witlout the facilities of intercourse afforded by railroads and canals. In no State are there greater means of communication between the people of the differcnt sections, than in Massachusetts; and in no State is there a more hamonious action in the Le fislatire department of the goremment. Let the railroads and ennals be so constructed in California as scon as possible, and the offect will be the same.

Wo have elsowhere mentioned and characterized the dimerent liarbors of California.. There has been one other surveyed and pronounced excellent, and the beyiming of a town made upon its shores. This is called IIumboldt, aftor the distinguished traveller. It is about ono humlred ant serenty-five miles north of San Trancisco. The river formerly called l'igeon, but now Trinity, cmpties into it. The harhor is sheltered fiom tho south-wets wind, lat is exposed to the northwost. The nortle-wost winds provail from Noromber till Maroh, aut are sovere; lut the south-west winds during the remuinder of the year, are riolont, and the larbor that is sholtered from them is considerel a good one.

The Indinns who inhabit a large portion of California, have loen, ant will be, the suljeot of considerable trouble to the white resilents. It is a matior of the first importance for their safety, and that of the Indians themsolves, that aments should be sent among them, with power to nogotinte and settle all claims mude by them and disputes arising between them and the whites, else, a destructire war will be the consequence. They should be induced to relinquish their 
claims to the soil of California as far as the Sierra Nevada, and receive due compensation therefor. But for the want of properly constituted agents from the gorernment, they hare been either driven from their oll haunts by the mountainecrs and other settlers, or remain amongst the whites to be a constant source of trouble. The Shosonecs, or Snakes, are the most numerous tribe to be found within the limits of the State, but there are others which are more warlike and untimeable. They have all suffered considerably from the aggressions of the white emigrants, and their attacks upon individuals and parties are but the yromptings of revenge, which should be taken into considcration. Lately, a war of extcrmination against the whole number of certain tribes was commenecil on account of the doings of one or two of them. Tew of them are provided with better weapons than bows and arrows, and, of conuse, they can make but a poor resistance to the rifics of the white men. In illustration of the treatment of the Indians, we quote an account of the dloings of a war party aguinst them, described in the work of a California tourist:-

"A few days before our arrival in the mines, five mon from Uregon, named llowinson, Thompson, English, Johnson, and Wood, were murdercal by Indians while engaged in gold digging. Ilaving but one rifle, they imprudently left it in their tont. This the Indians some thirty or forty in number, first securerl, and then commeneed their attack with bows and arrows. The Oregonians defended thonsclres sume time, repeatedly driving the Indians with no other weapons than the stones they found on the bar where they were at rork, but upon reaching the clige of the bur, they were cach time obliged again to retreat. At length three of 
them, stuck full of arrows, were cxhausted with loss of blood and orercome; while the other tro attempted to escape by crossing the fork, one succeeding in reaching the other side, but both finally meeting the fate of the others. One of the warriors of the tribe who participated in these murders was afterwards taken prisoner, and furnishing the above narration, his life was spared on condition that he should guide the whites to their rancheria.

"Accordingly, on the 16th of April, a war party was made up of about twenty young mountainecrs, mostly Oregion men, and including also the young Grecnwoods. Well mounted, and equipped with tho enormous gingling California spurs, they rode up to Old Grecntrood's for a reriew from the old man preparatory to starting. Each man carried besides his inscparable rifle, a long Spanish knife usually mounted with silver, and stuck in the folds of his deerskin leggings; and many were also provided with a brace of pistols or bowie lnife, worn in the red Mexican sash around the waist. Old Greenwood shouted 'Mind the scalps and squars for me, and be sure you bring ' $\mathrm{em}$ all in, boys,' and away they went, at a thundering lope, eager for revenge."

The day afterwards, the party returned. They wero precoded by a party of Perurians and Chilians, with a number of their peones, or slares.

"Following closely this motley group, came on foot a body of about sixty California Indians. Warriors and boys, squaws with pepooses tied on boards and slung at the back, all wore mrisoners. Clustered together like shep etriven to tho slaughter, they hastencil through the gorge with moertain steps, the porspiration rolling of their fuon now pale with fright. Miny 
of them wore quite naked, and the men and boys expocially, looked more liko ourung-outangs than human beings.

"In fank and rear rode the war party, which had lefo the Culloma Valley two Clays previous. Erery man's rille lay across the pommel of his saddle, and dangling at both sides hung several recking scalps. Among them was a dashing young mountaineer named John Ross, who had two scalps for his share, and sticking in his sash was the red-sheathed bowie linife, which the writer had sold him a fow lays previous for sin ounce of gold clust. Used previously to serer the rinds of pork, or shorel in rice and frijoles, it had now been 'wool gathering' or collecting wirgs for old Grecnwood's fancy stores.

"Well done, boys," shouted Grorer, "you have giren it to them this time; now, what's the news?' In reply to this inquiry, we learned that the captured Indian had led them the night before according to promise, to their rancheria, on Weber's Creek, where

- some of them showing fight anil others attempting cseape, they were fired upon and some twenty to thirty wore killed. Wheir chief fought until shot the third time, rising cach time to his lines and discharcing his arrows, Foss finally killing, cutting off his head and scelping hiv. Their pencherte was then searched and bumed; the Indians rldivering up the payers of the Oregon men, chaned at the time of their murter, and confessing that they hat afterwarts burnod their bodies to ashes on the mountains.

"The subsequent facts were related to the writer by his highly estemed fricur, Mr. Domald Grant, a native of bonnie Scotland, who was one of our party to the mines, and an eyo mitnoss to the scone; not 
haring left on his return to San Francisco till the following day.

"Arriving in the Culloma ralley with their prisoners, the mountaineers and miners had a grand revel and jollification to celebrate their achievement. During the day most of the prisoners were released, lout a few scquaws and seren warriors were retained. The latter were questioned and examined relative to their participation in the murier of the Oregonians. Nothing being elicited to prove their guilt, it was nerertheless determined that they should die; because being bad looking and strong warriors, it was believed they were participators in the murders. Accordingly the consunption of champaigne and brandy continued till sunset. At that hour the seren Indians were brought forth, and knowing well their fate, one of them put up his hand as a signal, and all leaped along the ralley in rapid flight. Quicis as thought the rifies began to crack in every direction, while old Greenwood raving around his cal:in remonstraterl at the deed, tosser his arms aloft with viclent denunciation; and stooping down gathered the chust in his palms, snd sprinkled it on his head, swearing the wes innoecnt of their blood. Meantime, John Greenwod stood beside the old man in stoic silence, ton brave to farticipate in the massacre, but ton much of a crow to utter his disapproral. But frantic with excitement the oflers thought only of revenge, and the balls whiriling in every direction laid five of the warriors deat in the valley and mortally wounding another, only one escaping unscathed. The dying rays of the sum deserting the bloody scene, yet lingered on the mountain top, and the smoke of tho discharge rolled in thick rolume, like a pall over the corpses of the slain, while that solitary warrior turned 
from his distant height, to gaze after his companicns, a moment in vain. But his heart quivered with rengeance, and the thin white locks of the old man in the valley, still mingled with the gray twilight, like the sackcloth and ashes of despair.

"And this is what they call fighting the Indians! A. few days before only, we saw a young mountaineer wild with rage, threaten the life of an American who had ventured to suggest, that the murders committed by these Indians were provoked by many previous murders by the whites, and that they should be arenged by the death of the guilty among the Indians, and not by an indiscriminate slaughter."

We cannot think highly of the civilization of the white men who take such unmerciful and indiscriminate revenge as this. Such are not the means to gain the Indians over to a peace. Rerenge only breeds revenge; and those who commit such slaughter in retaliation for the murder of one or two men must look to the consequences.

The great body of the travel to California is at present by way of the Isthmus of Panama; but those who intend to settle permanently in the State, and who will increase the real population of it, take the overland route from Independence, Missouri. The shortest and best route for commercial purposes will soon be opened across Nicaragua. This will have many advantages over the old Isthmus route, but will not cause that one to be abandloned altogether. Cha gres has become somewhat Americanized, and so have Gorgona, Cruces, and Panama. Travel has been somewhat facilitated by the addition of American boats on the Chagres River, and the provision of the mountain mules for the rough road to Panama, in sufficient 
number to lower the price of travel and decrease the delay.

The facilities of intercourse between California and the States east of the Rocky Mountains will tend to cement her to the Union by all the ties of trade and mutual interest. The people of that State, being at so great a distance from the rest of the States, would seem to be alien to them in interest, and, therefore, that an independent gorernment would contribute most to their prosperity. But mechanical influences - the telegraph-the railroad and the steam resselannihilate distance, and will be the means of attaching the Californians to the confeleracy. In her union with the other States, there is her strength. She will add much to their wealth and power, but her free institutions-entirely American, require the support of the confederacy which produced them-at least, until the State has reached her maturity.

What will be the future California is a question which artmits of a rearly answor. If she retains her present boundaries, with her extensive sea cosst, and her progress bears any proportion to that since the conquest, in fifty years-it is a warranted conclusionthe State will surpass any of those upon the Atlantic const. For, what State has such united commercial facilities and rast resources? Where are such internal wealth and such splendid haribors to be founds united? It is probalile, howerer, that the State may be divided, after the population has reached a sufil. cient number. It is the ophinion of sone of the members of the present Congress, that there is too much sea coast for one Strie to posses:, and that has been made an objection to her atnission into the Union, with her present boundaries. But it is of littlo weight at 
this time. After the State has existed a few years, the utility of such a division as is proposed will be manifest or clisproved. In the mean time, let California be admitted into the Union as her people have created her, and then she will have every thing necessary for her to go on in the fulfilment of a glorious destiny.

The gold discoveries in New Mexico and Oregon will have but a slight influence on California affairs. Iet for that slight influence, they deserve to be mentioned. The recent discoveries in New Mexico, would seem to indicate that the El Dorado of the early Spanish voyagers has been found, and nearly in the place to which their attention was directed by the Indians. A late number of the Houston Telegraph, says:

"That preparations are in progress in all parts of the State, for a grand expedition to the gold region that has been discovered in New Mexico, not far from the ruins of the celebrated city of Grand Quivira. Gold mines have been found all along the great chain of mountains extending from the sources of the Arkansas and Platte Rivers, by Santa Fe, to the Puerto. Immense excarations are shown along the feet of these mountains, and the ruins of rast cities indicate that these mines were once worked by millions of people. The geographical formations of this region are so similar to those of the gold regions of California, that they appear to be identical, and contain similar deposits of the precious metals. These facts have been made known throughout Texas, and the Telegraph would not be surprised to find that the emigration to the gold region of Texas, in the ensuing autumn, should exceed the emigration to California. 
The "consummation deroutly to be wished" has been attained. California has at length been admitted to take her place as a star of the confederated republic. The bill for that object passed the IIouse of Representatives on the Tth of Sicptember, 1850 , by a rote of yeas, one hundred and fifty, nays fifty-six. It had previously passed the Senate by a no less decisive majority. The announcement of the passage of the bill was received with the greatest enthusiasm by its friculs, and consirerable excitement upon the part of its opponents. The most constant exertions were made by members from the Southern States to defeat the bill by adjournment and by numerous amendments, but they were unavailing. California triumphed.

\section{CHAPTER XVI.}

NATURAL HISTORY OF CALIFORNIA.

A DEscriptroy or history of California would scarculy be complete without some account of the animal and regetable life, native to the country; and, happily, the information vion the sulject is copious and accurate. The trarcls and the obserrations of Fremont, Emory and ollere, have ilevelopel completely the character aut extent of the Califurnian vegetalle kinglum, and some foatures of it, partienlarly the great pine foreste, have becn the theme of general admiration among the tomists. Respecting the various species of beast, bird, fish and reptile, that belong to the country, we have not so full or 
exact information; but sufficient to make the subject interesting, and to satisfy the desire for general information. We shall begin with the animal kingdom.

The Grisly Bcar, Uisus Ferox, is the largest, most formidable and most ferocious animal in the country -and, indeed, in North Amcrica. Nimerous and almost incredible stories are related of its great strength and courage. Specimens are to be met with measuring four feet in height, and weighing from five hundred to one thousand poundis. Unlike the other kinds of bear, this species nerer climbs trees. His habits are solitary, and although a terrible foe to mect, he seldom becomes the aggressor against man. When his favorite flesh is not to be obtained, he will eat vermin, berries, and roots, in digging for which he frequently overturns fallen timber which a joke of oxen could scarcely move. On account of the imper-

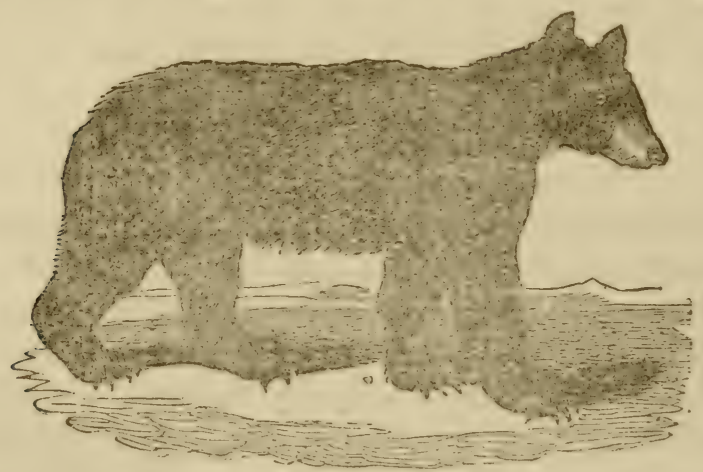

DLACK BEAR.

fection of their reapons, the Intians soldom renture to attack this animal; and wlemorer one is lilled by them, the occasion becomes a matter of great rejoicing, and the fortunate rictor becomes a man of conse- 
quence at once. The flesh of the grisly bear is by no means food to be despised, and the skin forms a comfortable couch for the hunter.

Besides the Grisly Bear, there are other species of the bear race to be found in California. The common Black Bear is two well known to need a description. The American lamen ground bear, is of a lighter color than the common bear, and in its habits, especially in regarl to its food, it resembles, in a great decrece, the brown bear of Norway. It feels principally upon fish. The grcat Polur Bear often makes his appearance on the extrome northern const of California, but camot be consilered as a California animal.

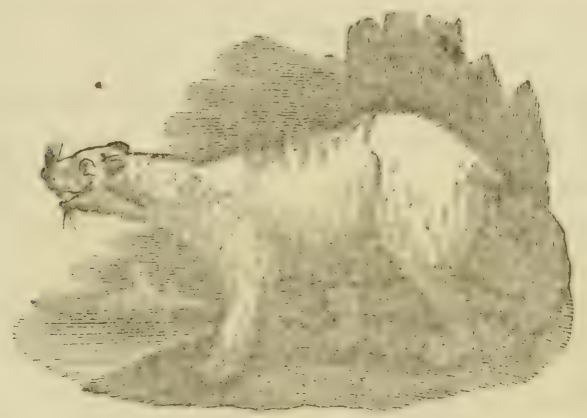

POLAR BEAR.

The Glutton, or Wolverine, which partalies of the nature of the bear, the fox, and the weascl, is well known to the bearer trappers, by the constant annoyance to which it smljects them, in dermuring their baits, and destroying their traps. It is a sarage, sullen creature, and thomgh not formidable to man, it preys upon small animals, and eren the decr. Stories are frequently told of the manner in which the wolrerine entraps the deer, and makes them his prey-by 
climbing to a branch of a tree, and letting down moss, upon which the victim comes to feed, and is immediately mounted by the Glutton, which never ceases its hold until the lacerated deer falls to the ground.

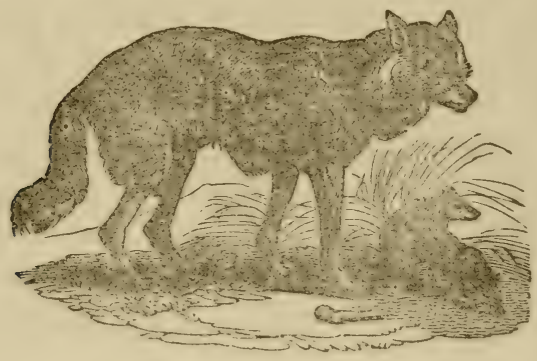

THE WOLF.

Several species of Wolf are found in California, and in some parts they are rery numerous. The Common Wolf, the Gray Wolf, Dusky Wolf, Black Wolf, and the Prairie Wolf all abound in different portions of the country.

Of Foxes, the most common is the American Red Fox (Canis Fulurs). The Red Fox has a much finer brush than the European, and is altomether a larger animal. The fur of the body is full, long, soft, and of a bright rufous brown; the skin is therefore valued as an article of trade, and about eight thousand are annually imported into England from the fur countries, where the animal is rery abundant, especially in the wooded parts. It is not, however, confined to the colder latitudes; its range, in fact, extends throughout the whole of the United States. In habits and manners the Red Fox agrees with our common Reynard, but possesses neither the same wind nor the same vigor and power of endurance. 
"It runs," says Dr. Richardson, "for about a hundred yards with a great swiftness, but its strength is exhausted in the first burst, and it is soon overtaken by a wolf or a mounted huntsman." Foxes of rarious gradations of color, termed Cross Foxes, are common in the fur countries of North America. These are considered by Dr. Richardson, and most naturalists, to be varicties of the Red Fox, and such is the opinion of the native hunters, than whom none are more likely to possess accurate knowledge on sucl points. The ordinary Cross Fox is distinguished by a gray fur mingled with black, which latter color prevails over the shoulders. A rarer and more valuable variety is the Black or Silrer Fox (Canis Fulvus, var. argentatus). Dr. Richardson states that seldom more than four or five of this variety are taken in a season at one post, though the hunters no sooner find out the haunts of one than they use every art to catch it, because its fur fetches six times the price of any other fur produced in North America. This fox is sometimes found of a rich, decp, glossy black, the tip of the tail alone being white; in general, howerer, it is silvered over ("sable silvered"), the end of each of the long hairs of the fur being white, producing a beautiful appearance.

The Racoon (Progyon Lotor) is found in California. As this animal, though often mentioned, is not often scen, we will describe its habits. In size, and in the colors of its fur, it bears some rescmblance to the foxes, but this resemblance does not extend far; the hairs are white in the middle, and black at the roots and the points, which produces a lind of gray resembling that which corers what are called the black and silver foxes; the tail is deep russet, surrounded 
by four or five rings of black; the under parts of the body are whitish, and so are the feet and the face, with the exception of a black band, which begins near the eye, and extends down the side of the neck; the claws have more the character of digging than of prehensile claws; the soles of the feet are furnished with five elastic tubercles upon each, one near the heel, one at the base of the thumb of the first toe and of the last toe, and the remaining one between the basis of the two middle ones, which toes are longer than any of the others; notwithstanding that it is partially digitigrade, and does not apply the whole length of the foot at every plant, the racoon is rather a clumsy walker, and their gait may be described as being heavy compared with the true digitigrade animals, though it is light as compared with that of the bears. They can readily stand erect on their hind fect, and lay hold with their fore ones; but this operation of grasping is not performed by the contracting of one paw, but by pressing both together. They do not possess the same pliability in the internal part of the fingers as the quadrumana, but, by clasping both pars together, they can, by this means, carry their food to their mouth. The animals have a habit of plunging their food in water, and then rolling it between their paws, before they devour it. Their sight is very delicate, and they have great difficulty in distinguishing objects in the bright sunshine, or any other strong light. In the daytime they generally remain inactive, seated on their posteriors, with the head reclining between the thighs, thus presenting the appearance of a ball; but, in the night, they evince considcrable activity in roaming abroad in quest of their food, which consists of worms, insects, 
fruits, and the roots of plants. They move about in all directions on the surface of the earth, searching the most minute and unfrequented holes and corners in quest of these; and they also climb trees with great dexterity, for the purpose, no doubt, of robling and plundering the nests of birds. They are particularly fond of drinking water, which they do by sucking it up into the mouth, and there is no necessary of life on which they seem to set greater value, or to relish more. They are said to frequent the banks of rirers and the sca-shore, for the purpose of catching molusca and fishes, which are their most farourite food. They are rery delicate in the sense of smelling, but heir organs of hearing are very imperfect. Their appearance resembles the bears more than any other of the carnassiers. Their generally fut condition of body, together with the thickness of fur with which they are clothed, gives them a clumsy rotundity of form. They have an extremely tufterl tail, but it loes not appear to be employed for any particular surpose in the economy of the animal. They are by no means difficult to tame-soon become familiarand seem to court caresses; but they do not seem to possess the quality of attachment to their master, or the docility to obey his commands. In order to prevent them from escaping, it is necessary to keep them chained up; for, though eaptivity softens their nature to a considerable extent, they never seem to yield up that spirit of independence which they possess in the wild state.

The American Badger (Meles Salvadoir 2 ) is found in the northern part of Califernia. It burrows in the sand and is particularly strong in the fore-feet. It is 
different in aspect and habits from the Badger of Europe.

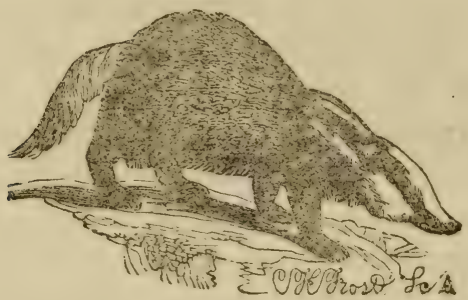

THE BADGER.

The Common Weasel (Mustcle Tulgaris) and the Ermine (Mustela Erminia) are both common in California, as also the Mink (Mustela Fison), the Marten (Mustela Martes), and the Skunk, (Mephitis Americana). They are well, though not very agreeably known, in all parts of the American continent.

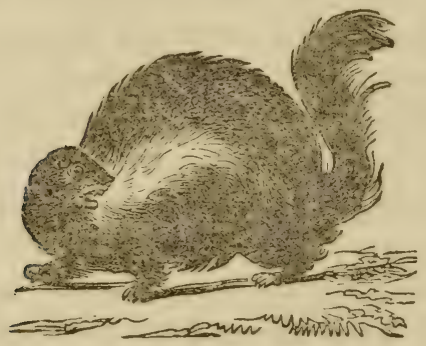

THE SKUNK.

Among the animals of the cat kind found in California, are the Northern Lynx (Felis Canadensis), Branded Lynx (Felis fasciata), Red Lynx (Felis rufa) and the Puma, or (Cougar Felis concolor); often called by the inhabitants, says Farnham, the lion. 


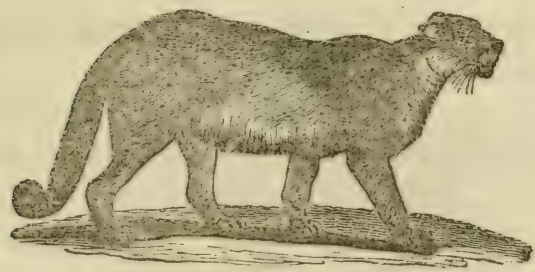

THE PUMA.

The Puma is found both in South and in North America, probably with some varieties of color; and if we are to credit some of the anecdotes which are related of it, we should be apt to consider it as a more formidable animal in the colder latitudes than in the warmer. This is certainly contrary to the natural analogies of the genus; and some of the anecdotes are, besides, such as cannot easily be brought within the range eren of possibility. It has, for instance, been gravely said, that the Puma has been known to carry the body of a man that it had killed up into a tree. Now, in the first place, it has not been very satisfiactorily ascertained that the Puma is a climber of trees, eren when it is notloaded; in the second place, if this were ascertained, it would be an argument against the killing of man, for the tree-cats are chiefly catchers of birds, squirrels, and monkeys; and, in the third place, notwithstanding all the marvels that have been told of lions and tigers, there is no feat at all comparable with this told of either of them. We have heard a similar story of a common brown bear carrying the body of a horse along a single treo which lay across a wide and deep ravine, in the Scandinarian forests, but we never supposed. that the tale was meant to be believed, and the feel- 
ing with regard to this feat of the Puma is much of the same kind.

The more probable accounts represent the Puma as attacking only the weaker animals, and as hoarding or burying its food; and pumas, when tamed, can be made to play with substances in the same way as young cats, only they are more indolent, and their motions not so graceful. It is well ascertained that the Puma is very casily tamed, and that, if it is fed, it shows not the least disposition to attack any animal, but shows considerable affection for those who are attentive to it. Its general manners are more like those of the domestic cat than, perhaps, any others of the genus, more so even than the wild cat of Europe, which is often, though it would seem erroneously, considered as the parent stock of the domestic. The Puma watches for birds in the same manner, and with the same action of the body, as the domestic cat, and like that animal, it purrs when caressed.

Mr. Farnham says, that on the Sacramento and San Joaquin Rivers, as well as on many parts of the coast, the common plain Seal, (Phoea Vitellina) is found, and on the same rivers the Musk Rat (Fiber Zibethicus) is often met with.

The Beaver (Castor Fiber), is another of the Californian animals, which is much sought on account of the value of its fur.

In an economical point of view, the Beaver is a very valuable animal. The fur is more glossy and beautiful than almost any other of the same fineness: it takes a rich black color, without haring its gloss in the lcast destroyed; it wears well, and is not much subject to injury from rain; and it very readily unites into a strong, though light and flexible fabric, by the 


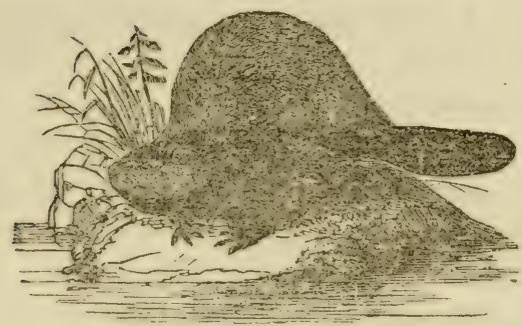

THE BEAVER.

operation called felting. Hats are put together by that operation, unless very inferior ones, in which glue is applied in supplement, which of course spots the hat, and refreshes with its unctuous droppings the head of the wearer during rain; and the fur of the bearer has those quailitics which render a much better material for hats than any other which is known. Accordingly it was very carly used for this purpose; and so exclusively used, when hats were fewer and beavers more numerous, that both the English and the Latin name of the animal became synonymous for the article of dress. At one period it was deemed necessary to enact statutes for preventing the admixture of any other material with the fur of beavers in the manufacture of hats; and at that time the hat outlasted the wearer, and could be washed in the same manner as a piece of woollen cloth; but in more modern times, owing partly to the great decrease in the number of beavers, and partly to the increased demand for hats, the article is so expensive that no hat is made entirely of beaver. The body is formed of wool, and that is plated over with beaver, which is worked fully through the body, or "felt," in good hats, but only very partially in infe- 
rior ones. A shower takes the bearer off the latter; and it is not rery long in wearing bare, and showing the felt in the former.

The skin of ti:c bearer is also ussod in the manufacture of gloves, and sometimes in that of shocs, though in the latter case the shoe, like the bad hat, recuires a little glue to make it saleable. Eren the glores are of rery inforior quality, as the skin is thick and rery rongh and loose in the texture; so that if it were not for the fur, the Bearors would not be deprived of their lives for the sake of their skins.

There is another part of the beaver which is used in medicine, though not so largely at present as formerly. It is a peculiarly metuous product, secreted by a follicle immeniately under the tail of the animal. It has a rery disargroeable smeil, and nanscous taste, but it was vince in high request as an antispasmodic,

- and also as producing an important and specific action on the uterine sretem. It is still retained in the Pharmacopoia, under the name of custorcum, or castor. It is not our provinee to cxamine its virtues as a drug; but we may observe that it was introduced into medicino at a time when nostrums were lield as being beneficial, rery much in proportion as they mere nasty; and to what extent this may be the case still, is also without our province.

In consequence of these uses in the arts, the Bearer has been hunted with great assidnity; and some idea of the total quantity killed in all parts which Beavers inhabit may be obtained from the fact that, in the year 1808 , there were 120,927 taken to England, from Canada alone.

Many stratagems are resorted to for the capture 
of an animal so much in request, but we shall notice these very briefly.

The slin of the cub-bearer is more highly prized than that of older animals, as being darker and more glossy; the winter season is preferred for capturing them, on account of the superiority of their coat at that time. There are various means employed in taking them. One of the ways in which they are captured is, by boring a number of holes in the ice, when they are driven from their habitations, which are then destrocerl. They remain under water a short time (as they are incapable of remaining in that element for any rery protracted period,) then by rising to the surface where the ice is broken, they are easily taken. At these times many of them retreat to the holes in the banks, where they lodge in summer; but these raults are soon discovered by experienced hunters, by striking on the ice with chisels, and they select such spots for their openings as they know will readily lead to the capture of their victims, and they are seldom mistalien. Another way in which they are taken is, to cut the ice both above and below their dwellings, nets are then thrown across, and the animals are driven from their aborles and compelled to enter the nets. It is usual, in summer, to take them in their houses, by what is called staking them. To effect this purpose the hunters first make an opening in the roof, in order to discover the exact position of the angle, and having adapted a number of stakes to the opening, so as to completely blockade it, they corer in the top, and leave the stakes on one side ready for use. This done, they drive the Beavers, by means of dogs, from all parts of the pond or river; and when the afrighted and hunted animals have suc- 
ceeded in reaching their homes, they again put up their stakes before the door-way, take off the temporary covering from the roof, and either take them in a living state, or spear them in their habitations. When they inhabit a sheet of water, which is merely kept up by a dam, they are still more readily taken, by letting off the water, and leaving their huts quite dry. The gun is also sometimes, though not very generally, used; and log-traps, baited with poplar sticks, are now and then made use of to commit havoc among them.

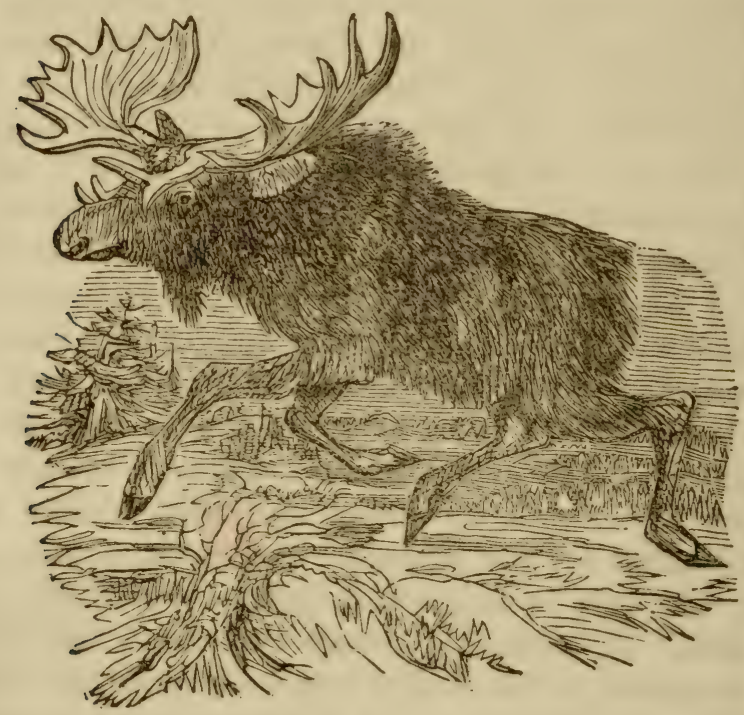

THE MOOSE.

The Moose or Elk (Cervus Alces) is found in California. This animal is the largest of his genus, being higher at the shoulders than the horse; its horns weigh sometimes near fifty pounds; accordingly, to 
bear this heary weight, its neck is short and strong, taking away much of the elegance of proportion so generally predominant in the deer; but when it is asserted that the elk wants beauty or majesty, the opinion can be entertained by those only who have seen the female, the young, or the mere stuffed specimens; for we who hare had the opportunity of viewing the animal in all the glory of his full-grown horns, amid the scenery of his own wilderness, no animal could appear more majestic or more imposing. It is, however, the aggregate of his appearance which produces this effect; for when the proportions of its structure are considered in detail, they certainly will seem destitute of that harmony of parts which in the imagination produces the feeling of beauty. The head, measuring above two feet in length, is narrow and clumsily shaped by the swelling upon the upper part of the nose and nostrils; the eye is proportionally small and sunk; the ears long, hairy, and asinine; the neck and withers are surmounted by a heavy mane, and the throat furnished with long coarse hair, and in younger specimens encumbered with a pendulous gland; these give altogether an uncouth character to this part of the animal. Its body, however, is round, compact, and short; the tail not more than four inches long, and the legs, though rery long, are remarkably clean and firm; this length of limbs and the overhanging lips, have caused the ancients to fancy that it grazed walking backwards. The hair of the animal is coarse and angular, breaking if bent.

The Elk is an inhabitant of northern latitudes; in Europe between the fifty-third and sixty-fifth degrees, making a part of Prussia, Poland, Sweden, Norway, 
Finland, Lapland, and Russia. In Asia it is found farther south, from thirty-five to beyond the fiftieth, spreading over Tartary, and abounding in Japan, if indeed the denomination of Elk is not misstated for that of Rusa, or an undescribed species. In America it resides between the forty-fourth and fifty-third degrees, round the great lakes, and over the whole of Canada and New Brunswick.

Its movements are rather heary, and the shoulders being higher than the croup it does not gallop, but shuffles or ambles along, its joints cracking at every step with a sound heard to some distance. Increasing its speed, the hind feet straddle to avoid treading on its fore-heels, tossing the head and shoulders like a horse about to break from a trot to a gallop. It does not leap, but steps without effort over a fallen tree, a gate, or a split fence. During its progress it holds the nose up, so as to lay the horns horizontally back. This attitude prevents it seeing the ground distinctly, and as the weight is carried very high upon his elevated legs, it is said sometimes to trip by treading on its fore-heels or otherwise, and occasionally to give itself a heavy fall. It is probably owing to this occurence that the Elk was believed by the ancients and the vulgar to have frequent attacks of epilepsy, and to be obliged to smell its hoof before it could recover; hence the Teutonic name of eleud (miserable), and the reputation especially of the fore hoofs as a specific against the disease.

During the winter montls, the Elk resides chiefly in hilly woods, in snowy weather seeking the covers, and in clear the open spaces. In summer it frequents swamps on the borders of lakes, often going deep into 
the water to escrpe the sting of gnats, \&c., and to feed without stooping. Its usual food in winter consists of the burts and bark of button-mood, spruce, and juniper pine, bircle and meple, and under the snow it scels stink roonl (Ancrymis fuetida) and mosses, but this is always with difficulty, for then it is obliged to sprear the foro leg", or eren it is said to knecl. The branches of trecs it tumb down with the horns rery dexterously; but to ect at the ground we have been assured by Iluron ant the Camadion hunters, when the snow lias fullen only a foot or two in depth, that the herd, led by an old male, shorel it back, and throw it over their learls, the snow folling on cither side, as it slicles from the inclined planes of the back of their horns; meantime the fo: o fect of all are equally engaced in striking it from under them.

During a part of the jear, the herd consists of an old female, two alult females, two young females, and two joung males; but during the snowy periols, at least in America, one or mone alult males are certainly among them, rery oll males alone leeping alocen wntil the rutting senson, unle:s the winter be very serere. Sereral of these families keep near each other, and in rery cold weatler they seek coter together, and remain closcly pressel against each other, or trot in a circle till they have beaten the snow down. When the rutting periol commenees, which is about the begrinning of September, tho old males seck the females, and expel the young, who are obliged to kecp aloof while the animals remain iin leat. At this time they will swim rivers in pursuit of the females, or after them to remain concealed in some of the Lake Islands. The males are then very pugnacious; they bellow often and sink in flesh. The gravid females bring forth 
about the middle of May, at first one, but ordinarily two calves, of a brown red color. These are so simple and void of fear that in the first months they are easily taken, and if in the water, where they willingly go to avoid the flies, they will suffer persons in a canoe to come up to them and take them by the head without appearing in the least frightened.

The dags, prickets, or incipient antlers are the first year not more than an inch in length; the second, they rise to a foot; the third, they are forked; and the fourth, they assume six snags and are somewhat flattened; the fifth year the blade is still small, but their expansion from that time forward is uniform, though it does not appear that the number of snags ever exceed twenty-eight. In a very large specimenthere were twenty-two, the length, from the head to the tip twenty-seven inches, and from tip to tip across the horns three feet six; the trio lower snags on either side separated by a deep indenture; the weight about thirty-three pounds. Old Elks shed their horns in January and February, and, if lean from a severe winter, in March; the younger later, till the month of May. They are again completely restored in the former by the end of June, and in the latter in August.

Several other species of deer are found in California. Among others are the Large Eared Deer (Cervus Macrotis). This is a species, resembling the Virginian and Mexican deer, and also in some respects the Wapiti; but according to the descriptions of Harlan and Say, it is different. The upper part is light reddish brown, and the sides and fore part of the nose ash color; the back intermixed with blackish tipped hairs, which form a distinct line on the neck 
near the head; tail reldish-cinereous black at the tip; this part is somerrhat compressed, and almost

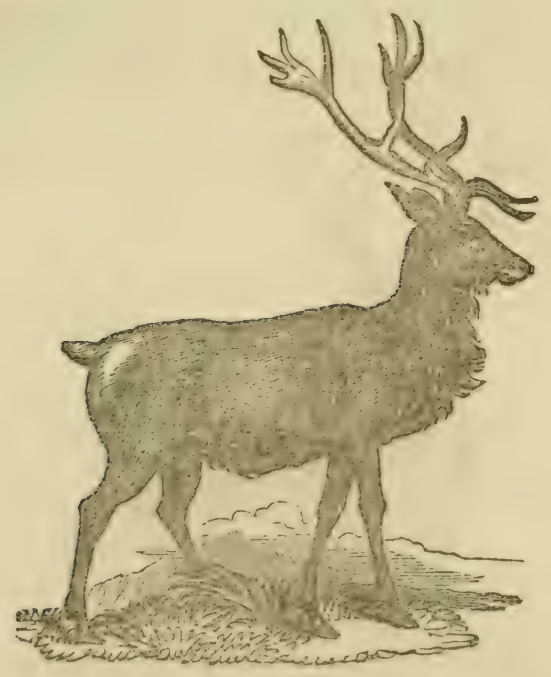

THE IARGE EARED DEER.

naked beneath; the hoofs are shorter and wider than those of the Virginian Deer, and more like those of the Wapiti; the homs slightly grooved and tuberculated at base with a similar antler, as in the Virginian; the beam less curvel forwarls, is bifurcated near the summit, again divided, the anterior of the sccond bifurcation being somewhat longer than the posterior; the ears rery long, extend to the principal bifurcation, about half the length of the whole horn; the lateral incisor teeth are largor in proportion to the intcrmediate than in the Virginian; ejelashes black; lachrymal apertures also larger, and the hair coarser, and undulated, and compressed like that of the Wa- 
piti. The species is found in the most remote northwestern territories of the United States, and from the context of this description it appears evident that the Guazupuco Deer is nearest allied to it, and that the Guazuti and the Virginian are clearly of the same group.

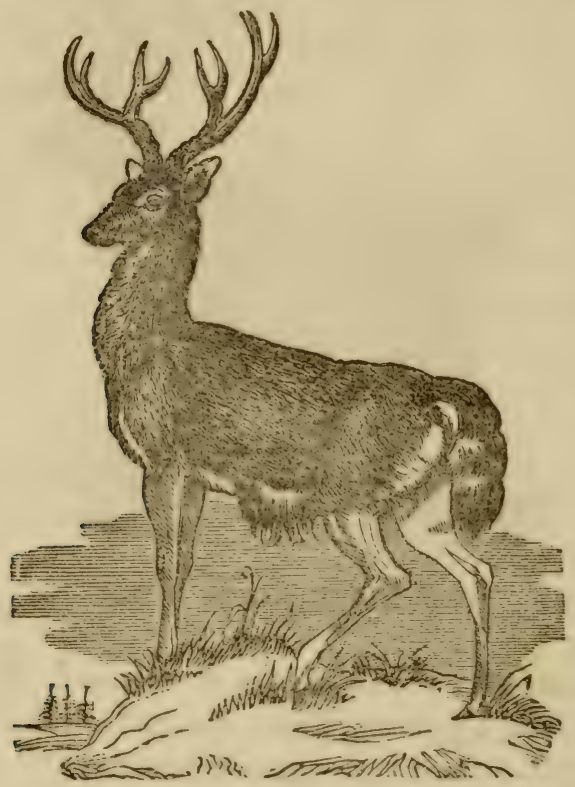

THE LONG-TAILED DEER.

The Long-tailed Deer (Cervus Macrourus) is another California animal. This species is described as being larger than the Red Deer or Stag of Europe, darker in color on the upper part, and having the belly white, the tail, frow which it gets its specific name, different from that of most species of deer, is about eighteen inches in length, black on the upper part, but with broad white margins, and carried erect when 
the animal runs. The horns are short and altogether of small size and flattened, but not palmated.

The Pronghorn Antelope (Antitope Furcifur) is another beautiful species of deer found in California. It is found chicfly in the mountain regions, where it is often seen to tantalize the hunter by its extreme shyness and its great agility.

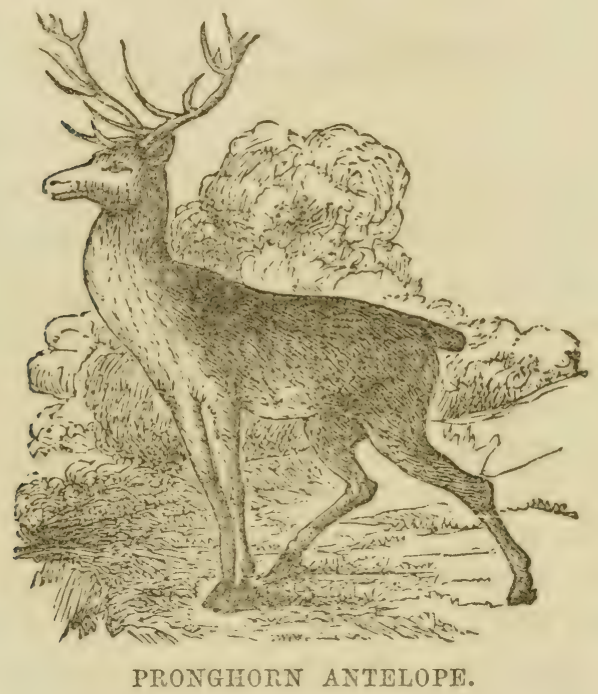

The Argali Oris Montanoe is found in California, is sometimes called the Rocky Mountain Sheep.

By some the goat of the Rocky Mountains has been confounded with this animal; and it has also been called an antelope, though it is neither the one nor the other, but truly and properly a goat. The characters of this species, or probably variety (for it really seems that, notwithstanding all the diversities of the genus Ovis, whether in the wild or the cultivated state, there 


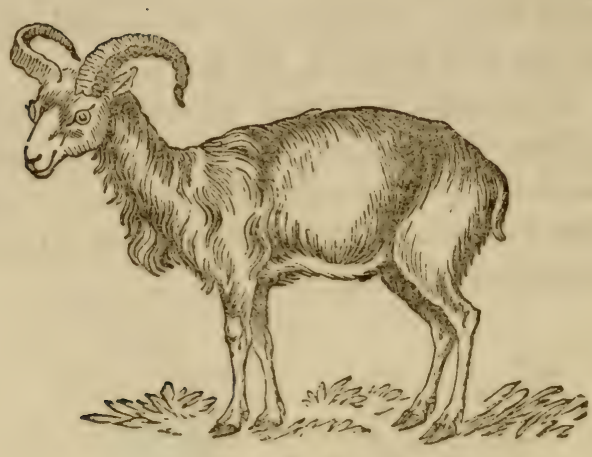

ARGALT.

is no well made out distinction more broad than that of variety,) are rery apparent, and at once prevent any possibility of confounding it cither with the antelopes or the goats, though of course, as all sheep do, it approximates more closely to the latter of these than to the former. The body is remarkable for its thickness and roundness in proportion to its length; the legs are very long; the outline of the forehead, seen in profile, is nearly straight; and the muzzle is almost exactly that of the common sheep. The horns of the male are very thick and large; they advance in front of the eyes, and form nearly an entire turn of a spiral. They are flattened laterally like those of the domestic ram, and have similar transrerse furrows and ridges. These furrows and ridges are very conspicuous on the basal half of the length of the horn, but much less so on the terminal half; and of the three latcral faces the front one is the largest. The horns of the female are much more slender than those of the male; they are compressed, nearly straight, and without furrows; there are, in some instances, plates or folds of skin under the throat, especially in the male; 
the tail is very short in both sexes; the color in summer is generally grayish fawn, with a reddish or Jellowish line down the back, and a large patch of the same color on the buttocks; and the under part, and the insides of the legs are cither russct, Jellowish, or of a white sand color; in winter the color of the upper part is more reddish, and the throat and breast are more inclining to white; but the patch on the buttocks remains much the same at all scasons.

These animals are found in little flocks, of about twenty or thirty in each, on the Rocky Mountains, and extending southward as fur as California. Several naturalists hare expressed their conviction that the mouflon of the sonth of Europe, the Arcali of Asia, and the wild shecp of America, are only climatal rarieties of one great species, to which they have given the name of "mountain sheep;" but whether this is or is not positirely the fact, we have no means of ascertaining. Probability is in farer of it, howerer, and the more so that, among the domesticated sheep, which we have erery reason to believe are all originally of the same stock, whaterer that stock may have been, there are differences of external appearance fully greater than any which are to he met with among the wild ones; and we believe that, in the whole genus, there are no differenees but external ones. Some futher confusion and uncertainty is produced among these wild sheep by the contuct of the keepers of muscums, who hare filled these with horns and other scrap., not having any history, ant which have, in consequenes, been referred to places where they are not to be found. The great puzzle in the history of this genus, however, is the proneness which it has to break into varieties, not only in different countries, 
but in the same country, and even in the same flock. There are, however, other two species or varieties which are worthy of notice, though even they do not settle, or tend to settle, the question of common origin.

The Bison (Bos Americanus) is extremely rare now in California, though supposed to have been common in former times.

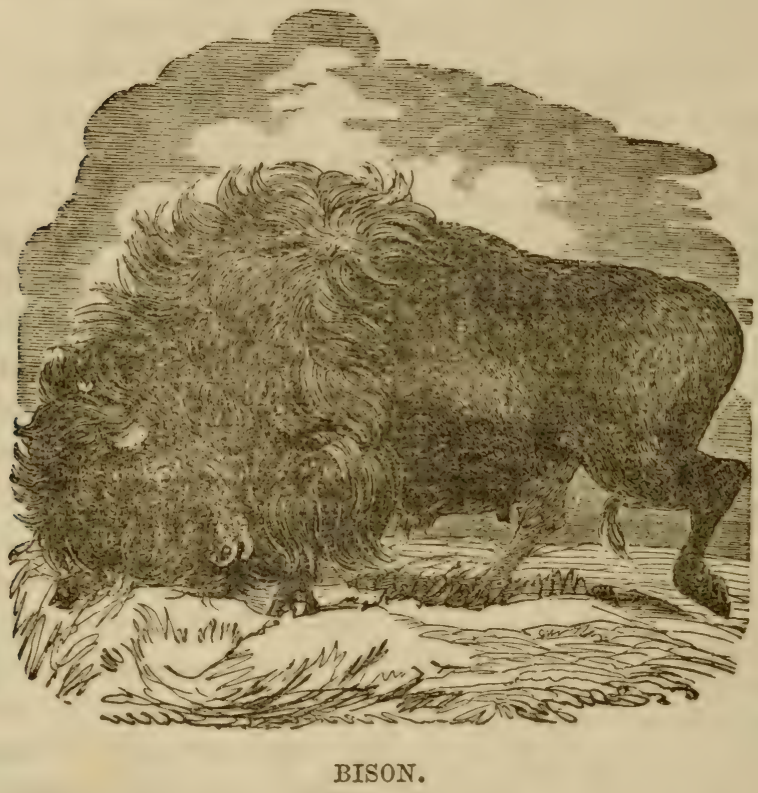

Like its congener the aurochs, the American Bison is of powerful frame, and exceeds in bulk the ordinary race of cattle, its height at the fore-quarters being upwards of six feet, and its weight from twelre to fifteen hundred weight, and sometimes much more. The head is huge, ponderous, and carried low; the withers are massive and elevated; the eyes are small 
and their expression is ferocious ; the horns are small and black. The neck, withers, and chest, are covered with a profusion of long shaggy hair, contributiug ta render the appearance of the animal wild and terrific; the hinder quarters are clothed with shorter wool. The general color is umber brown, acquiring a rusty tint in winter. Endowed with the sense of smell in great perfection, wary and fierce, the Bison associates in large herds conducted by one or two old bulls, whose motions the rest appear to follow; but herds of bulls also live separately. Their food consists of grass and rank herbage, to obtain which in winter they scrape away the snow with their feet. On the approach of an enemy the herd immediately takes to flight; but if one be wounded, the life of the hunter is placed in great jeopardy, for turning in a moment, it rushes on its assailant with headlong impetuosity and with determined resolution. Sereral fatal instances might be cited in which the hunter has perished from want of caution in attacking this formidable beast, and many hairbreadth escapes are on record.

In defending itself from a dog the Bison strikes violently with its fore-feet and easily keeps its annoying foe at bay.

The flesh of this animal is accounted excellent, the tongue and hump, or flesh on the top of the withers, being especial delicacies. The chase of the Bison is therefore assiduously carried on, both by the natives and the Europeans.

The Bison swims well, and during the heats of summer vast herds make their way to shady rivulets, streams, and pools, in which they delight to plunge and bathe. Herds of twenty thousand, crossing rivers upwards of a mile in breadth, have been seen, as 
Lewis and Clarke inform us, or darkening the plains on their passage to fresh feeding-grounds.

- Salt springs, or saline morasses, or salt-licks, are great attractions to this animal, and at all seasons are visited by numerous herds. Those, however, are incessantly thinned by the hunters, and the time is not probably far clistant when the American Bison will be as rare and as limited in its extent of range as the aurochs of Lithuania.

At certain seasons of the year the bulls engage in terrible conflicts, and rush furiously upon man, or any other animal which rentures near them. With the cxception of man, the most formidable enemy against which the Bison has to contend is the huge grisly bear, and before this dreaded monster the strongest bull goes down.

It appears that the Bison will breed with the ordinary race of domestic cattle, a gainst which the aurochs displays the greatest antipathy, though in ono respect the latter approaches nearer to the common ox than does the Bison; we allude to the number of ribs, which are thirtecn in the ox on cach sicle, fourteen in the aurochs, and fifteen in the Bison.

The Sea Otter (Lutra ILarina), so renowned for its valuable fur, is found on the coast, and the Land Otter (Lutra Brasiliensis) in the rivers.

The Sen-Otter is a native of the north-west coast of America, from California to latitule $60^{\circ}$, and of the opposite coast of Asia, from the Fellow Sea to the north of Kamtchatka and the intermediate islands. Its fur, which is of a black color, sometimes chestnutbrown, and occasionally eren yellow, is soft, full, and beautiful, and is an object of commerce, being pro- 
cured by the Russians for the Chinese market, where it sells for a high price.

This animal haunts sea-washed rocks, and lives mostly in the water, where it procures its food, which consists of fish, and, as is indicated by the character of the teeth, which are evidently formed for bruising hard substances, shelled mollusks, and crustacea. In summer the Sea-Otter often ascends the rivers to the inland lakes. The female produces on land a single cub. The average length of this species is three feet, exclusive of the tail, which measures about ten inches.

There are several species of rats, mice, marmots, and squirrels in California. Mr. Farnham informs us that the Pouched Rat (Pecudostonia bursarium), and the small marmot (Arctomys Beecheyi), are found in California, the latter being very plentiful in the plains near San Francisco and Monterey, burrowing in the ground and carrying in its capacious chest pouches, a store of nuts, corn, and acorns. There are several other varieties of the Arctomys, such as the Prairie Marmot (Arctomys ludovicianus), and the Woodchuck, (Arctomys Monax, the latter is found in the Atlantic States.

It does not inhabit the rery cold places of America, but rather the central and southern parts of the United States, and perhaps places further to the south; for Catesby styles it "the Bahama rabbit." In the United States it is called the ground hog, and various other local names, none of which are very applicable. Its color is rusty brown, rather darker on the flanks than on the middle of the back; a portion round the muzzle is bluish gray, and the tail is black.

Among the animals of the squirrel kind enumerated 


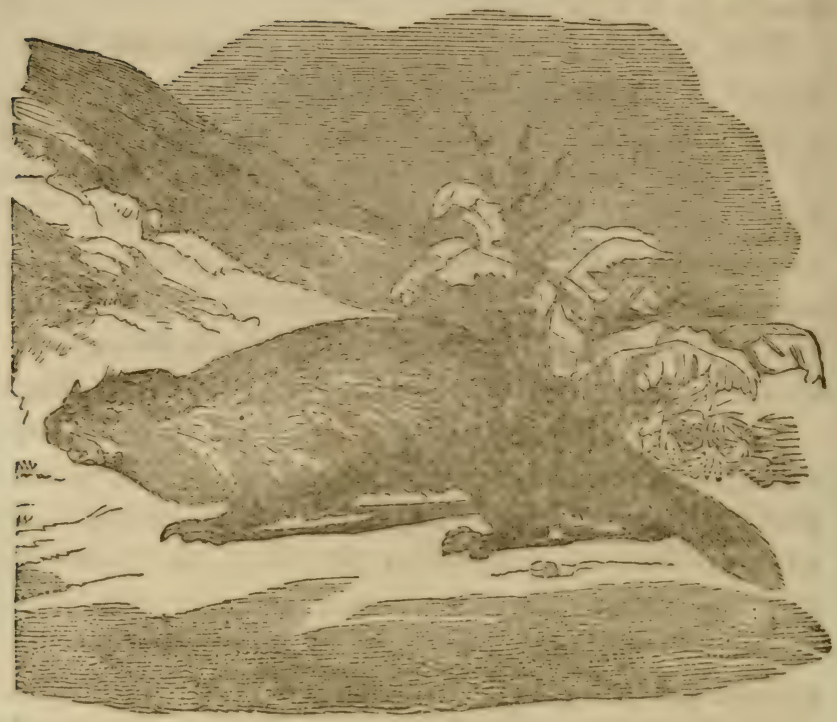

WOODCHUCK.

by Mr. Farnham, are the Gray Squirrel, (S'ciunes Cinereus, ) the Great-tailed Squirrel (Sciurus macrouveus), the Flying Squirrel, the Striped Squirrel, and the Black Squirrel (Sciumes niger.) The last is a beautiful species sometimes found in the Atlantic States.

Its face is describod as being in general black, but with some white markings very differently placed in different indiriduals. In some the nose is white, in others the fcet; in others, again, the tip of the tail; yet, again, there is a white collar rom the neck; and these markings may all appear in the same individual, or any number of them may appear in any of the combinations which they can forni. These circum. 


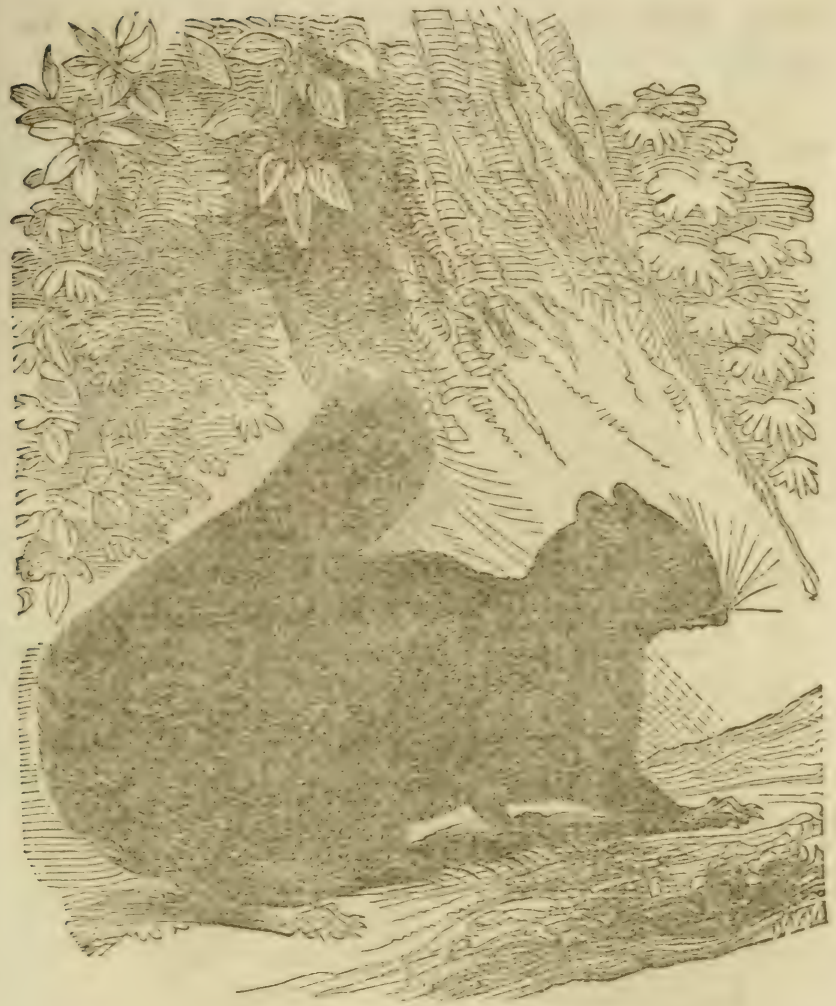

THE BLACK SQUIRREL.

stances render the history of the species uncertain; but it appears, if a distinet species, to be pretty widely spread, for it has becn obtained in the States and also in Mexico. It is described as being a much more social animal than the gray squirrel.

Of the IIare there are sereral fine species, one weighing from eight to twelve pounds, which Mr. Farnham supposes to be the Leprus glacialis; another is the Prairie Hare (Lepus Tirginianus), and the 
Little Hare (Lepus princeps), only six inches in length.

Among the more remarkable birds of California, are the following:

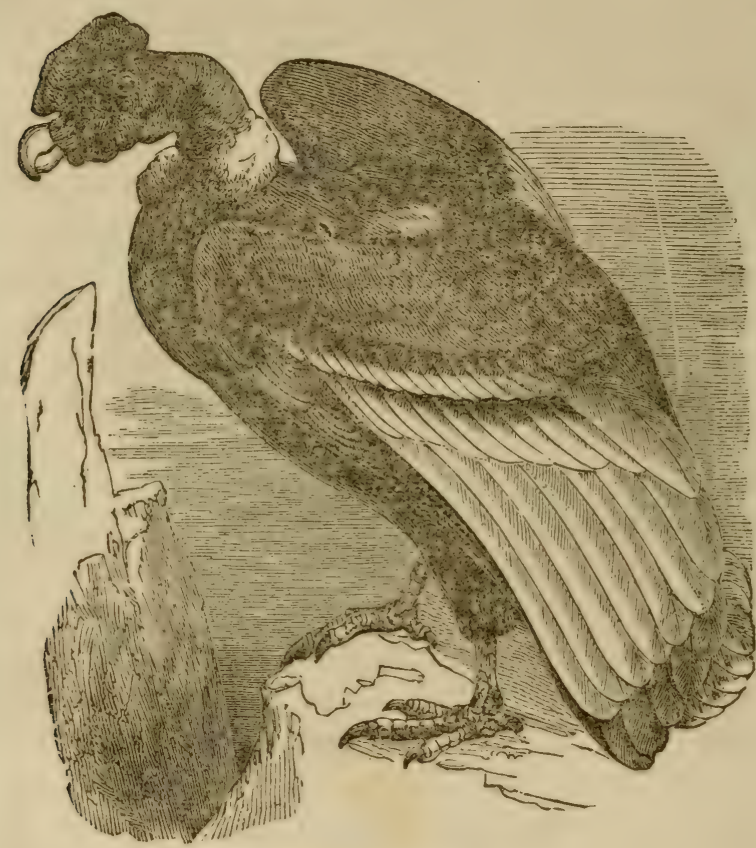

THE CONDOR.

The Condor (Vulture condor) is the celebrated vulture of America, of whose size, strength, and daring, so many marrellous tales have been told, that had there been any such animals as elephants in South America, it is highly probable that we should have had an account by "eye-witnesses," of the Condor flying clear over Chimborazo with an elephant in its claws. We 
have no room to go into its history, and it is not necessary, as it may be found any where, since Humboldt brought it within reason and reasonable dimensions. It is only a little larger than the mountain vulture of the Alps, and its habits are nearly the same; but the appendages to the naked part of the bird bring it more within the present section. The color is blackish, with great part of the wings ash, and the collar on the neck silky and white. The male bas one large carunculated membrane above the bill, and another below; but these are wanting in the cemale. The female is nearly of a uniform grayish orown; and the young in their first plumage are ash orown, and without the collar of feathers upon the aeck. Eren after all the exaggerations are discounted, the Condor is a bird of no small interest. It is the most lofty-dwelling bird of the whole class; and the regions of storm and earthquake which it inhabits are of themselves well calculated to give it a very peculiar importance.

Cathartus are the vultures of North America, some of which hare occasionally been confounded with the Condor; and, though none of them are equal to that bird in story, they rival, if not exceed it, in size and in power. We cannot go into the details of all the species, of which there are several; and therefore we shall give a few particulars of one as a specimen.

Californian Vulture, (Cathartus vulturinus.) This is a very large bird, about four feet and a half in length, and nearly ten feet in the stretch of the wings. It inhabits North America to the westward of the Stony Mountains, and is particularly abundant in the lower valley of the Columbia. It is a woodland bird, and does not appear to inhabit very high latitudes, 
though, like the vultures of the eastem hemisphere, it is more northerly in the summer than in the winter. Their general color is brown, without any rery deciled markings; they nesile in the thick woods, choosing the tallest pines in the willest and most inaccessible parts of the mountain valleys. The nest is composed of sticks and coarse grass, and the pair occupy it for many years in succession. The eggs are two, of a jet black color, nearly round, and about the size of those of a goose. The hatching time is about the first of June, and the incubation lasts about thirty days. The young are at first covered with whitish down, and fivo or six weeks clapse before they are able to quit the nest.

Where these birds inhabit is truly a Tulture's country, as the turns of the seasons are particularly violent both on land and at sea. Many land animals are beaten down by the rains, or orertaken by the swelling rivers; and when the storm abates, the wreck both of the land and the water is great. This is indiscriminately eaten by the vultures, which make common prize both of fishes and of land animals, and heed not much how far they may be gone in putrefaction. Their senses are kecn, especially their sense of sight, and we shall not enter upon the disputed keenness of the sense of smell in vultures, which, to say the best, appears to have been most gratuitously exaggerated. When on the reconnoitre, or tracking the progress of a wounded animal, they fly rery ligh ; and, though there may not be one in sight when it falls, the carcass of a large animal speedily attracts a number of vultures; and they come to a recent earcase just as readily as to a tainted one, to that which does not smell with the same readiness as to that 


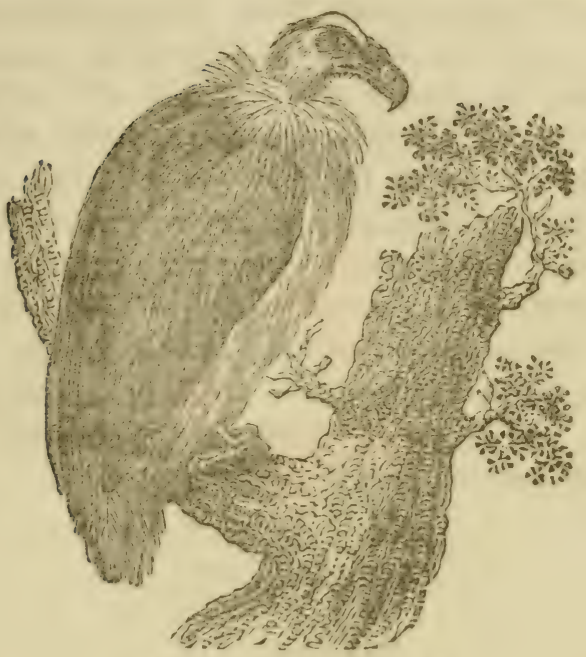

CALIFORNIA VULTURE.

which docs, and this is agrainst the common notion of the acuteness of their scent. Indeed the foetid distillation from thir orm nostrils is a pretty strong argument against their smelling power; a man with his nose constantly bathed in assafoetida would not be in the best condition for finding roses by the scent. "Their roracity," says the lamented Darid Douglas, "is almost insatiable, ancl they are extremely ungenerous, sufiering no other animal to approach them while feeding. After cating they become so sluggish and indolent as to remain in the same place, until urged by hunger to go in quest of another repast. At such times they porch on decayed trees, with their heads so much retracted as to be with difficulty observed through the long, loose, lanceolate feathers of the collar; the wings at the same time hang down over the feet. This position they invariably preserve 
in dewy mornings, or after rains. Except after eating, or while guarding their nest, they are so excessively wary that the hunter can scarcely ever approach sufficiently near for even buck-shot to take effect on them, the fulness of the plumage affording them a double chance of escaping uninjured. Their flight is slow, steady, and particularly graceful, gliding along with scarcely any apparent motion of the wings, the tips of which are curved upward in flying. They are seen in greatest numbers, and soar highest before hurricanes and thunder-storms. Their quills are used by the hunters as tubes for tobacco-pipes."

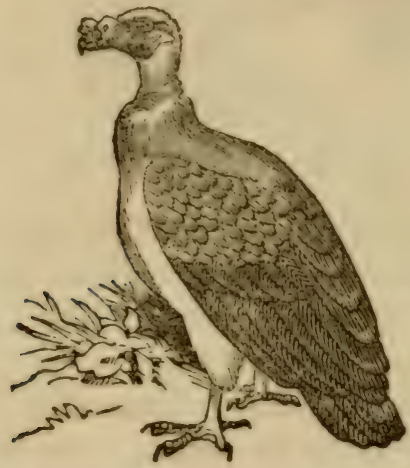

TURKEY BUZZARD, OR TURKEY VULTURE.

The Turkey Vulture (Cathartus aura) is another American species of smaller size, and more generally distributed. It is about two feet and a half in length, and six feet in the expanse of the wings. The upper parts are nearly black, with some white markings, and the lower parts sooty brown. They are common in the United States, but leave the northern ones in the winter.

The Black Vulture (Cathartus atratus) is a darker 
and smaller species; and so familiar that it frequents the torrns, and plies as a scavenger in the streets, in which oflice it is protected loy the inhabitants. It is about two feet two inches in length, and four feet four inches in the stretch of the wings. The general color is dull black, with Eome white on the insides of the primary quills. It is a dull and sluggish bird, and the smell of it is peculiarly offensive.

The Golden Eagle (Aquila Chrysaetos,) is one of the most powerful of the cagle tribe. Its feathers are much prized liy the Indians as ornaments, and are attached to their pipes or calumets, whence they call the bird the Calumet Lacle. It is scen on the coast and in the woods and muntainous parts of California.

The following are nearly the average external characters of the female Golden Eagle, which is the more powetul bird, and therefore the typical one, at that age when the color's expressive of youth bare disappeared, and those of old age have not come on :-Tip of the bill and the claws black; basal part of the hill bluish; naked skin or cere at the base of the bill, and ters, which are the only naked parts of the feet, yellow; irides of the eyes bright orange brown, inclining to yellow; crown of the head and nape of the neck bricht orange brown; sometimes, in birds which have passed a certain age, margined with white, which beemes broader as age increases. The fenthers on the neck narrow, pointed, and very distinct, bristling ont from each other when the bird is in a state of excitement; chin and throat rich dark brown, passing craciually into pale reddish brown on the under part, in which it terminates in the rent feathers, and feathers on the tarsi, the latter being slender and very much produced; upper part deep orange brown, 


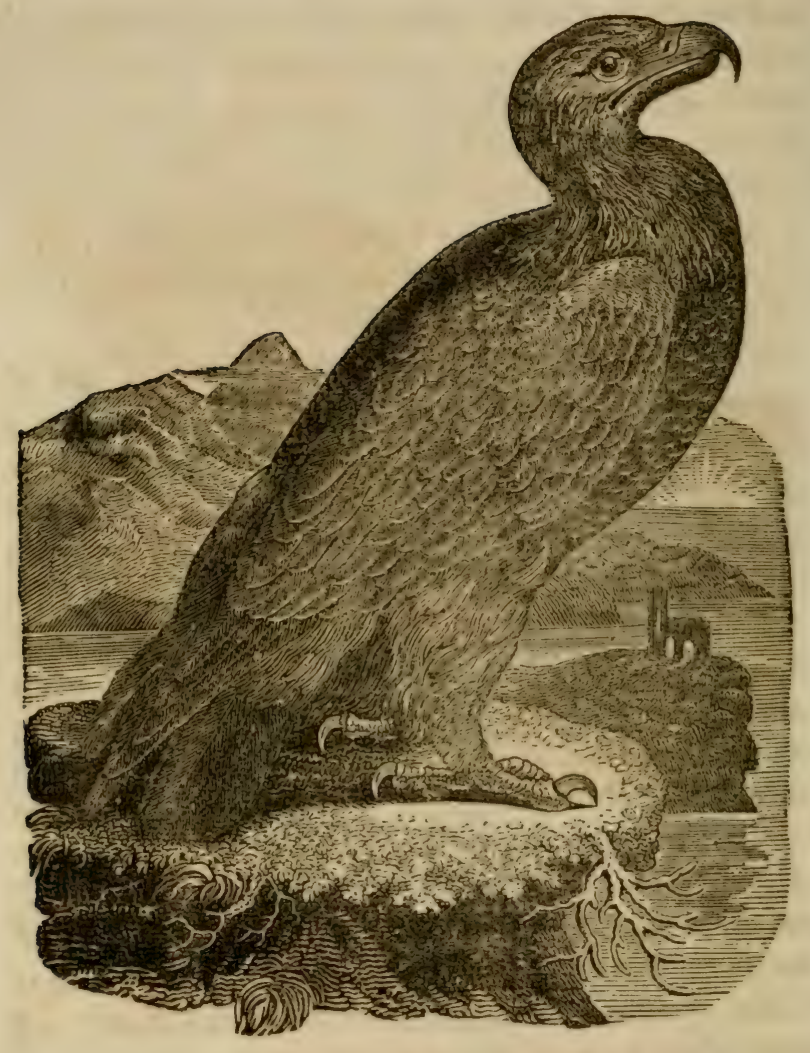

GOLDEN EAGLE.

margin rather paler, which gives a bold relief to the individual feathers; coverts of the wings nearly the same; secondary quills clouded with various shades of brown; and primary quills black. Tail purplish brown, barred across with blackish brown, and having a broad line of the same across the extremity. The feathers are all remarkable for the firmness of their texture, and their profusion in the eagle feather, which 


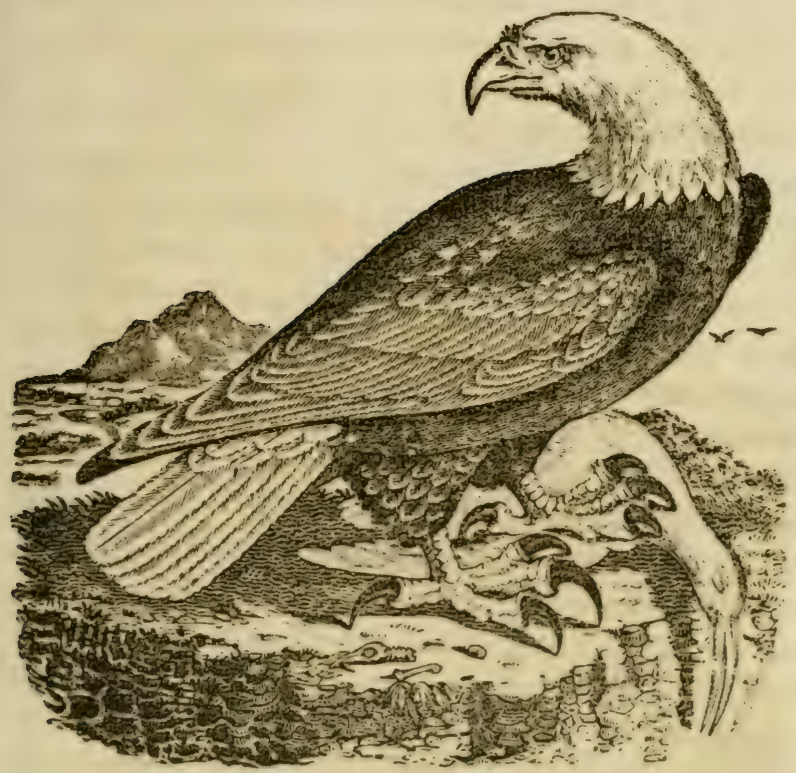

\section{BALD EAGLE.}

gives them something of the same appearance as if they were imbricated scales.

The Bald Eagle (Aquila leucocephalus.) As this bird is certainly much more characteristic of North America than of any other part of the world, and, as it is there a bird of the greatest interest, we should be doing it injustice if we attempted to describe it in any other language than that of Wilson:- "This distinguished bird," says this equally distinguished naturalist, "as he is the most beautiful of his tribe in this part of the world, and the adopted emblem of our country, is entitled to particular notice. The celebrated cataract of Niagara is a noted place of resort 
for the Bald Eagle, as well on account of the fish pro. cured there, as for the numerous carcasses of squirrels, deer, bears, and various other animals, that, in their attempts to cross the river above the Falls, have been dragreel into the current, and precipitated down that tremenlous gulf, where, among the rocks that bound the rapids below, they furnish a rich repast for the vulture, the raven, and the Bald Eagle, the subject of the present account. Formed by nature for braving the severest cold; fecding equally on the produce of the sea, and of the land; possessing powers of flight capable of outstripping even the tempests themselves; unawed by any thing but man; and, from the ethereal heights to which it soars, looking abroau at ono glance, on an immeasurable expanse of forests, fields, lakes, and ocean, deep below him, he appears indifferent to the little localities of change of seasons; as in a few minutes he can pass from summer to winter, from the lower to the higher regions of the atmosphere, the abode of eternal cold, and from thence descend, at will, to the torrid or the artic regions of the earth. Ile is, therefore, found at all seasons in the countries he inhabits; but prefers such places as hare been mentioned abor, from the great partiality he has for fish.

"In procuring these, he displays in a very singular manner the genius and energy of his eharacter, which is fierce, contemplative, daring, and tyranical ; attributes not exerted but on particular occasions, but, when put forth, overpowering all opposition. Elevated on the high dead limb of some gigantic tree, that commands a wide view of the neighboring shore, and ocean, he seems calmly to contemplate the motions of the various feathered tribes that pursue their busy arocations below; the snow wiite gulls slowly win- 
nowing the air; tho busy tringre coursing along the sands; trains of ilucks streaming orer the surface; silent and watchful cranes, intent and wading; clamorous crows; and all the winged multitudes that subsist by the bounty of this rast liquid magazine of nature. IIigh over all these hover's one whose action instantly arrests his whole attention. By his wide currature of wing, and sudten suspension in air, he knows him to be the fish hawk, settling over some devoted rictim of the deep. His ere kindles at the sight, and, balaneing himsclf, with half-opened wings, on the branch, he watches the result. Down, rapid as an arrow from heaven, descends the distant object of his attention, the roar of its wings reaching the ear as it disappears in the deep, making the surges foam around. At this moment, the eagrer looks of the Eagle are all ardor; and, levelling his neck for flight, he sees the fish hawk once more emerge, struggling with his prey, and mounting in the air with screams of exultation. This is the signal for our hero, who, launching in the air, instantly gires chase, and soon gains on the fish hawk; each exerts his utmost to mount above the other, displaying in these rencontres the most clegant and sublime aerial evolutions. The unencumbered Eagle rapilly adrances, and is just on the point of reaching his opponmt, when, with a sulden scream, probably of despair and honest execration, the latter drops his fish : the Eagle, prising himself for a moment, as if to take a more certain ain, decents like a whielwind, snatches it in his grasp ere it reaches the water, and bears his ill-gotten bowty silently away to the wools."

The Fish Hawk (Aquila Ildiveta) referred to abore, inhabits the coast and many larts of the interior of this country. The flight of this bird is easy 


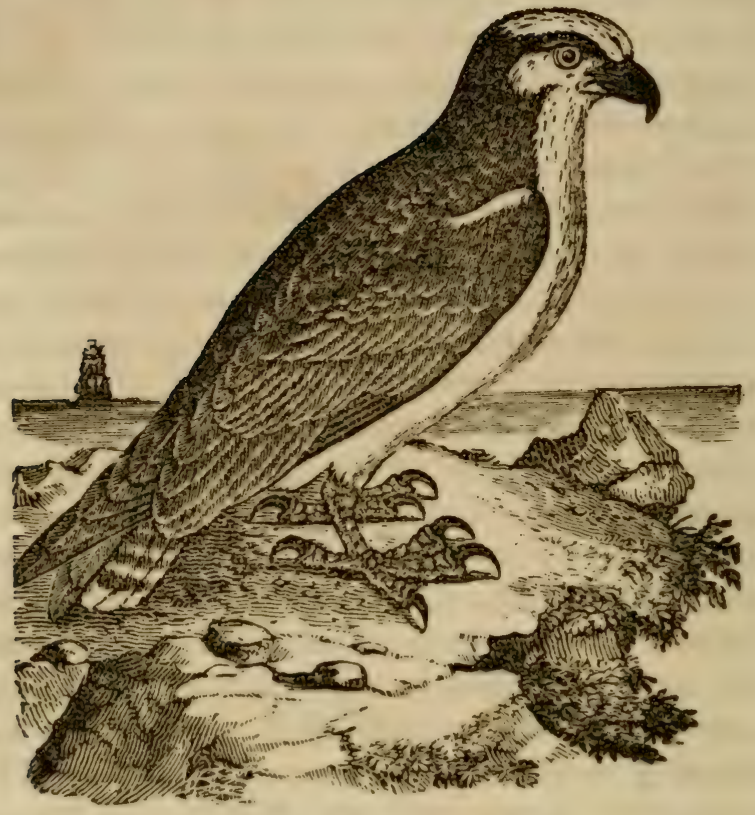

THE FISH IIAWK.

and graceful, and its plunge, when sweeping down to its firny prey, inconceivably rapid. Audubon says that it never strikes at a fish leaping out of the water. In the Gulf of Mexico, where these birds are numerous, and where shoals of flying-fish are continually emerging from the sea to escape the pursuit of the dolphins, he observed that the Fish-hawks never made a sweep at them, but would at once plunge after them, or other fish, while swimming in their usual mode near the surfice. When it plunges into the water in pursuit of a fish, it sometimes proceeds deep enough to disappear for an instant, throwing the water around isto foam; on rising, it mounts a few yards into the 
air, shakes off the spray, and flies off to its nest with its booty, or to an accustomed tree, there to satisfy its appetite, when, without longer repose, it again launches into the air, and sails circling at a great height over the waters.

The nest of the Fish-hawk is built in a tree, and consists of a mass of sticks, seatreed, grass, turf, \&c., and being repaired every year, is sometimes a fair cartload. Among the interstices of the materials, other birds are permitted to nilify, and several pairs of grakles, or crow-blackbirds, may be often seen taking up their abode around the margin and sides of the strueture, "like humble rassals round the castle of their chief," laying their eggs, rearing their young, and living together in the utmost harmony.

The Fish-hawk breeds in May; and both parents are deroted to their young, defending them from any assailant with indomitable resolution, and using both beak and talons with terrible effect. The young are generally three in number.

The Peregrine Falcon (Falco Peregrinus). This bird so famous as haring been used in the princely sport of hawking in old times, is found in this country. Mr. Selby, in his British Ornithology, gives an instance of great daring in a Falcon. "In exercising my dogs upon the moors previous to the commencement of the shooting season, I observed a large bird of the hawk genus hovering at a distance, which upon approaching I knew to be a Peregrine Falcon. Its attention was now drawn towards the dogs, and it accompanied them while they beat the surrounding ground. Upon their having found and sprung a brood of grouse, the falcon immediately gave chase and struck a young bird before they had proceeded far 


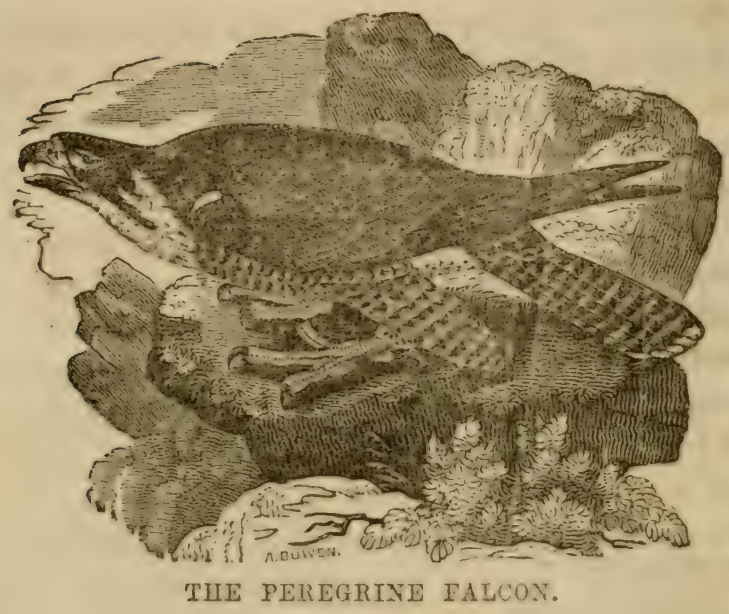

upon the wing. My shouts and rapid adrance prerented it from securing its prey. The issue of this attempt, however, did not deter the Falcon from watching our subsequent movements; another opportunity soon offering, it again gave chase, and struck down two birds by two rapidly repeated blows, one of which it secured and bore off in triumph." The flight of this Falcon when pursuing its quarry is astonishingly rapid. Montagu has reckoned it at one hundred and fifty miles an hour; and Colonel Thornton, an expert falconer, estimated the flight of one in pursuit of a snipe to have been nine miles in eleven minutes, without including the frequent turnings. Audubon, in his "Birds of Amcrica," states that he has seen this Falcon come at the report of a gum, and carry off a teal not thirty steps distant from the sportsman who had killed it, "with a daring assurance as surprising as unexpected."

This singular aptitude in the wild bird to join men 
and dogs in their pursuit of game, availing itself of their assistance, shows at once the little trouble comparatively speaking, requisite for reclaiming and training it. A knowledge of the service rendered by dogs and men in putting up game, thereby giving it the opportunity of striking it, is intuitive. In disposition it is confident and docile; and with patience, kind treatment, and proper management, its training is soon effected.

The Peregrine Falcon, breeds on the ledges of precipitous rocks, laying four eggs, of a reddish brown color, with darker blotches and variegations.

The Fen Falcon (Falco Islandicus) is large, strong, exceedingly compact and very firm in its plumage. The male bird is about twenty"two inches long, and the stretch of its wings about four feet. The female is still larger. This bird is found in Upper California. Among other birds of the Falcon tribe are the Sparrow Hawk, (Falco Sparverius), Pigeon Hawk, (Falco Columbarius), and the Gos Hawk (Accipiter Columbarius).

There are several species of the $\mathrm{O} w \mathrm{l}$ in California. Among these is the Hawk Owl (Strix Funerea), a remarkable species which forms the connecting link between the falcons and the hawks. This bird preys on small birds, and sometimes follows the hunter like a falcon and boldly siezes the wounded game as it flutters on the ground. IIe also feeds on mice, squirrels, and insects. Sometimes the Hawk Owls are observed to horer round the camp fires of the natives in quest of any offal or rejected game.

The Virginian Horned Owl (Bubo Virginia 'us), common in the United States and the fur colisiries, is found here. The flight of this bird is elevated, 


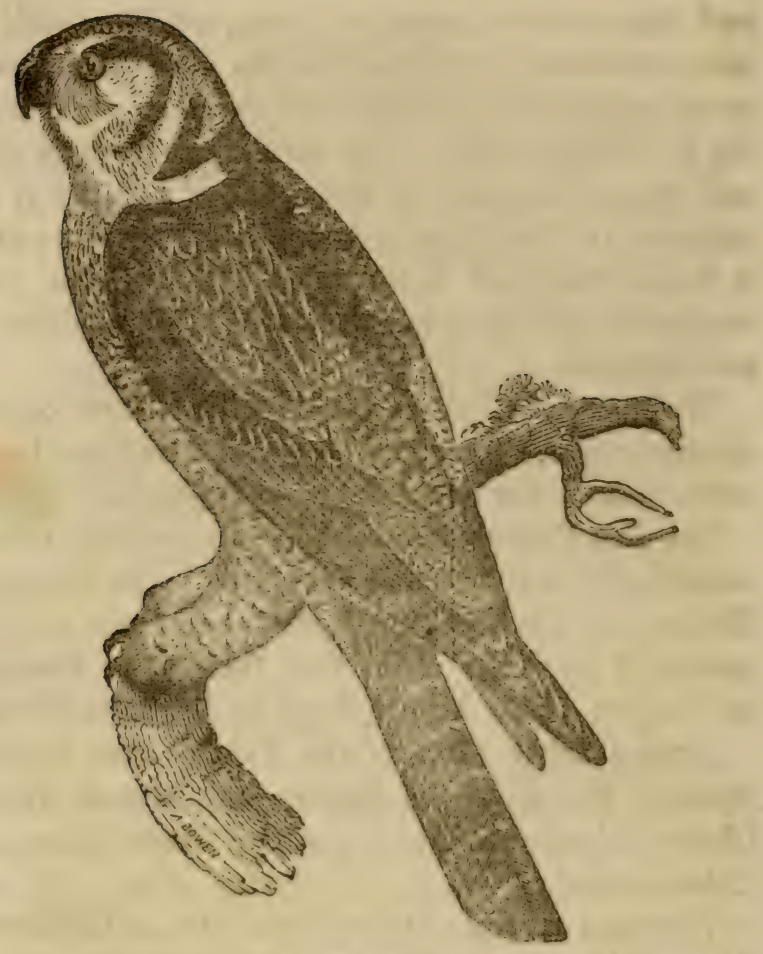

HAWK OWL.

rapid, and graceful. It sails with apparent ease in large circles, and rises and descends without the least difficulty, by merely inclining its wings or its tail as it passes through the air. Now and then it glides silently close orer the earth with incomparable velocity, and drops as if shot dead on the prey beneath. At other times it suddenly alights on the top of a fence, stake, or dead stump, and utters a shriek so horrid, that the woods around echo to its dismal sound. During the utterance of the deep gurgling 


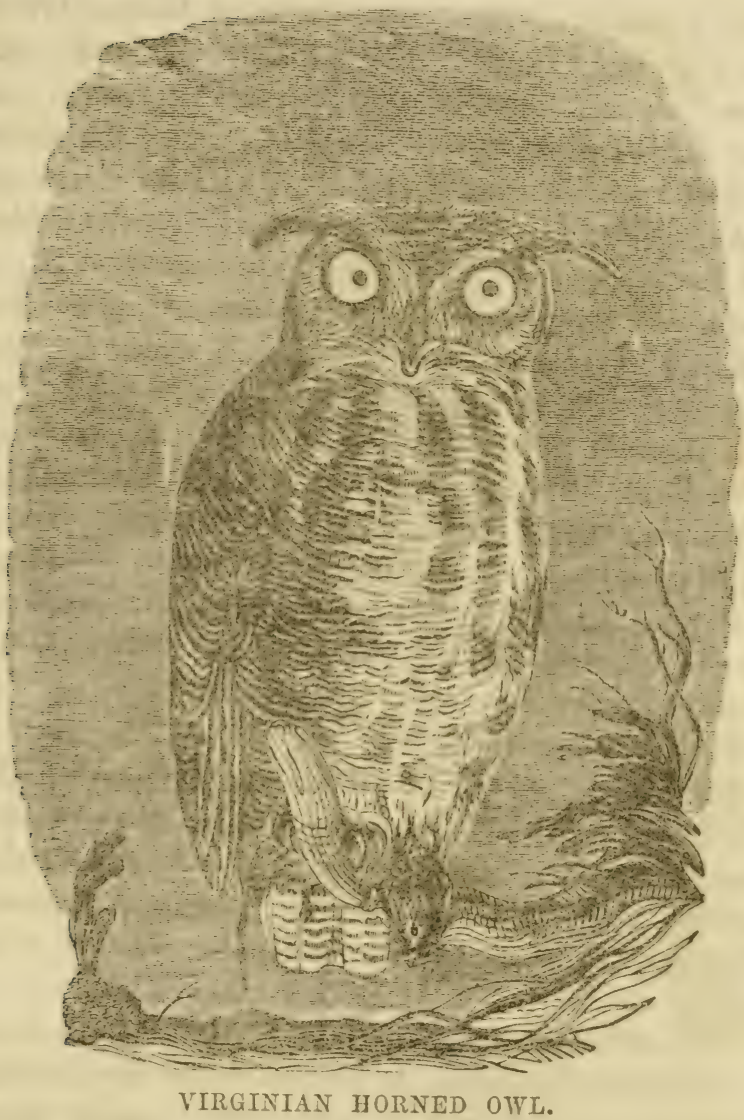

cries so wall described by Wilson, it mores its body, and particularly its hear, in rarious grotesque ways, and at intervals violently snaps its bill. Its food consists of rarious gallinaceous birds, half-grown turkeys, domestic poultry of all kinds, lucks, grouse, hares, opossums, and squirrels; and whencver chance throws a dead fish on the shore, this bird feeds on it 
with peculiar avidity. The Virginian Horned $0 \mathrm{wl}$ is very powerful, and equally spirited. Mallards, guinea-fowl, and common fowls fall an easy prey, and are carried off in its talons to the depths of the woods. When wounded, says Audubon, it exhibits a revengeful tenacity of spirit, scarcely surpassed by the noblest of the eagle tribe; disdaining to scramble away, it faces its enemy with undaunted courage, protruding its powerful talons, and snapping its bill. Its large goggle eyes open and shut in quick succession; and the feathers of its body are puffed up, and swell out its apparent bulk to nearly double the natural size. In some districts it is a great nuisance to the settler, making sad havoc among his stock of poultry. Among some of the Indian nations a sort of reverential horror is entertained towards this bird, and the priests and conjurers have adopted it as the symbol of their office, carrying about with them a stuffed specimen with glass eyes, which excites general awe. This bird usually constructs a bulky nest in the forked branch of a tree, composed externally of crooked sticks, and lined with coarse grass and feathers. The eggs are three or four in number, and of a dull white.

The Mottled Owl (Strix nævia), a small, handsome species known as the Little Screech Owl, inhabits California and Oregon as well as the Atlantic States. They feed on small birds, beetles, crickets, and other insects, build in hollow trees, and utter most dismal shrieks in the late summer and autumn evenings, keeping up the din till midnight. Mr. Farnham mentions the Great Snow Owl (Strix Nictoca), and the Burrowing Owl (Strix Cunicularia) which inhabits the 


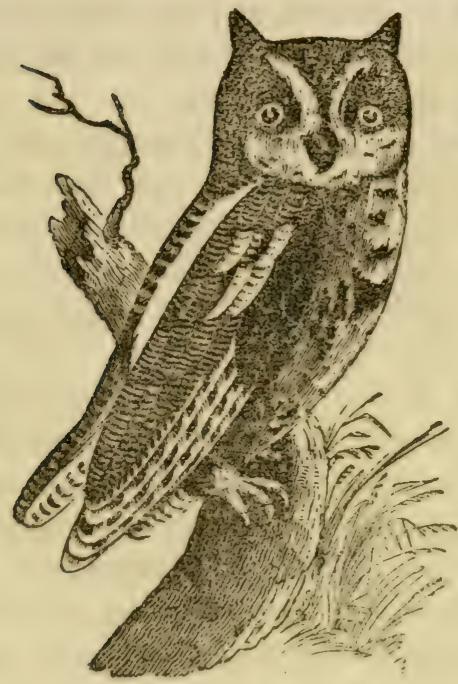

THE MOTTLED OWL.

burrows of the Prairie Marmot. This bird is thus described by L. Bonaparte.

"In the trans-Mississippian territories of the United States the Burrowing Owl resides exclusively in the villages of the marmot or prairie dog, whose excavations are so commodious as to render it unnecessary that our bird should dig for himself, as he is said to do in other parts of the world where no burrowing animals exist. These villages are very numerous, and variable in their extent, sometimes covering only a few acres, and at others spreading over the surface of the country for miles together. They are composed of slightly elevated mounds, having the form of a truncated cone, about two feet in width at base, and seldom rising as bigh as eighteen inches above the surface of the soil. The entrance is placed either 
at the top or on the side, and the whole mound is beaten down externally, especially at the summit, resembling a much-used footpath.

"From the entrance, the passage into the mound descends vertically for one or two feet, and is thence continued obliquely downwards, until it terminates in an apartment, within which the industrious marmot constructs, on the approach of the cold season, a comfortable cell for his winter's sleep. This cell, which is composed of fine dry grass, is globular in form, with an opening at top capable of admitting the finger; and the whole is so firmly compacted, that it might, without injury, be rolled over the floor.

"In all the prairie-dog villages the Burrowing Owl is seen moving briskly about, or else in small flocks scattered among the mounds, and at a distance it may be mistaken for the marmot itself when sitting erect. They manifest but little timidity, and allow themselres to be approached sufficiently close for shooting; but if alarmed, some or all of them soar away or settle down again at a short distance; if further disturbed, their flight is continued until they are no longer in view, or they descend irto their dwellings, whence they are difficult to dislodge.

"The burrows into which these Owls have been seen to descend, on the plains of the River Platte (a tributary to the Missouri), where they are most numerous, were evidently excavated either by the marmot, whence it has been inferred by Say that they were common though unfriendly residents of the same habitation, or that our $\mathrm{Owl}$ was the sole occupant of a burrow acquired by the right of conquest. That the latter idea is correct was clearly presented by the ruinous condition of the burrows tenanted by the $\mathrm{Owl}$, 
while the neat and well-preserved mansion of the marmot showed the actire care of a skilful and industrious owner. We have no evidence that the $\mathrm{Owl}$ and marmot habitually resort to one burrow; yet we are well assured by Pike and others that a common danger often drives them into the same excaration, where lizards and rattlesnakes also enter for concealment and safety. The Owl observed by Vicillot in St. Domingo digs itself a burrow two feet in depth, at the bottom of which its egges are reposited on a bed of moss, herb-stalks, and dried roots.

"The note of our bird is strilingly similar to the cry of the marmot, which sounds like cheh, cheh, pronouncel several times in rapir suecession; and were it not that the Burrowing (isls of the West Indies, where no marmots exist, uter the same sound, it might be inferred that the marmot was the unintentional tutor to the young owl: this cry is only uttered as the bird begins its flight. The food of the bird we are describing appears to consist entirely of insects, as, on examination of its stomach, nothing but parts of their hard wing-cases were found.'

The American Shrike, or Buteher Bird (Lanius Septentrionalis), is found here. His principal food is large insects, such as grasshoppers, crickets, and spiders, sometimes impaling them on thorns, possibly as a lure to smaller hirds, which he snmetimes attacks and tears in pieces with lis slarp houked bill. He is noted also for his imitative powers as a songster; but his usual note is hiscorlant and hoarse.

There are screral species of the Fly Catcher. Among others, the well known King Bird, or Tyrant Fly Catcher, (Muscicapa Tyrannus.) Among smaller American birds, the most pugnacious and intrepid. 


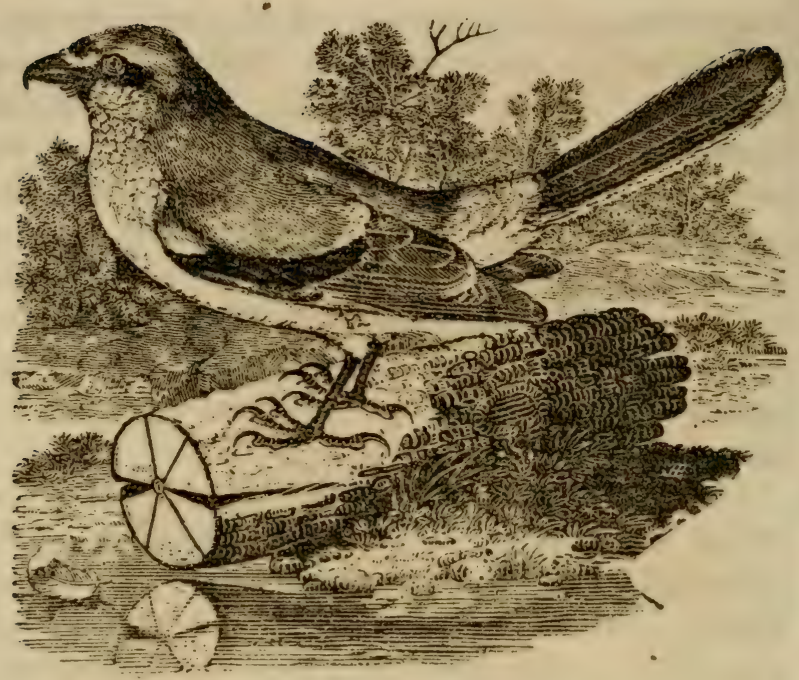

AMERICAN SHRIKE.

On this bird, Nuttall has the following remarks :

"In a natural state he takes his station on the top of an apple tree, a stake, or a tall weed, and betwixt the amusement of his sqeuaking twitter, employs himself in darting after his insect food. Occasionally he is seen hovering over the field, with beating wing, almost like a hawk, surveying the ground or herbage for grasshoppers, which are a farorite dict. At other times they may be observed in small companies flickering over still waters in the same employment, the gratification of appetite. Now and then, during the heat of summer, they are seen to dip and bathe, in the watery mirror, and with this washing, drying, and pluming, they appear to be both gratified and amused. During the season of their sojourn, the pair are often seen moving about in company, with a rapid quiver- 


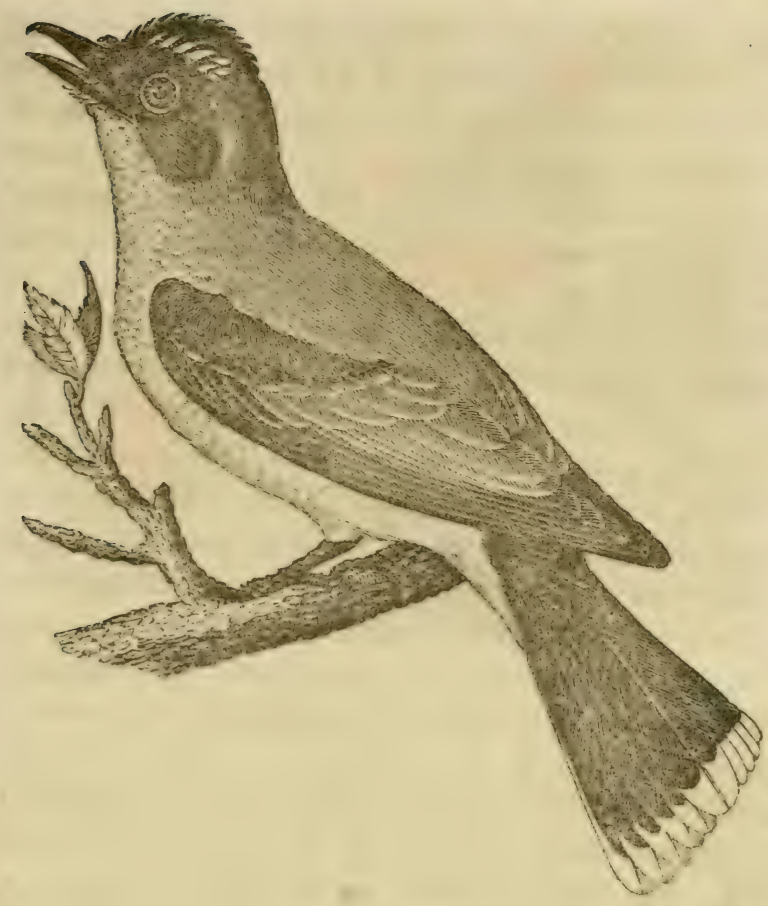

KING BIRD.

ing of the mings, anit a continued tremulous shrieking twitter. Their energetic and amusing motions are most commonly performed in warm anil fine weather, and continue, with little intermution, until towards the end of August.

"One of the wost remarkalile traits in the character of the King Birl, is the conrage and affection which he displays for his mate and young; for on lis first arrival he is rather timid, and rcallily dorlges before the swallow and purple marten. Indeed, at this season I have seen the spotted sandpipers drive 
awa.y a pair of King Birds, because they happened to approach the premises of her nest. But he now becomes, on this important occasion, so tenacious of his rights as readily to commence the attack against all his feathered enemies, and he passes several months of the summer in a scene of almost perpetual contest, and not overrating his hostile powers, he generally finds means to come off with impunity. Eagles, hawks, crows, jays, and in short every bird which excites his suspicion, by their intentional or accidental approach, are attacked with skill and courage; he dives upon the heads and backs of the larger intruders, who become so annoyed and tormented as willingly to make a precipitate retreat. He pursues his foes sometimes for a mile; and at length, assured of conquest, he returns to his prominent watch-ground, again quivering his wings in gratulation, and rapidly uttering his shrill and triumphant notes. He is, therefore, the friend of the farmer, as the scourge of the pilferers and plunderers of his crop and barn yard. But that he might not be perfectly harmless, he has sometimes a propensity for feeding on the valuable tenants of the bee hive; for these he watches, and exultingly twitters at the prospect of success, as they wing their way engaged in busy employment; bis quick-sighted eyes now follow them, until one, more suitable than the rest, becomes his favorite mark. This selected victim is by some farmers believed to be a drone rather than the stinging neutral worker. The selective discernment of the eyes of this bird has often amused me; berries of difierent kinds, held to my domestic King Bird, howerer similar, were rejected or snatched, as they suited his instinet, with the nicest discrimination." 


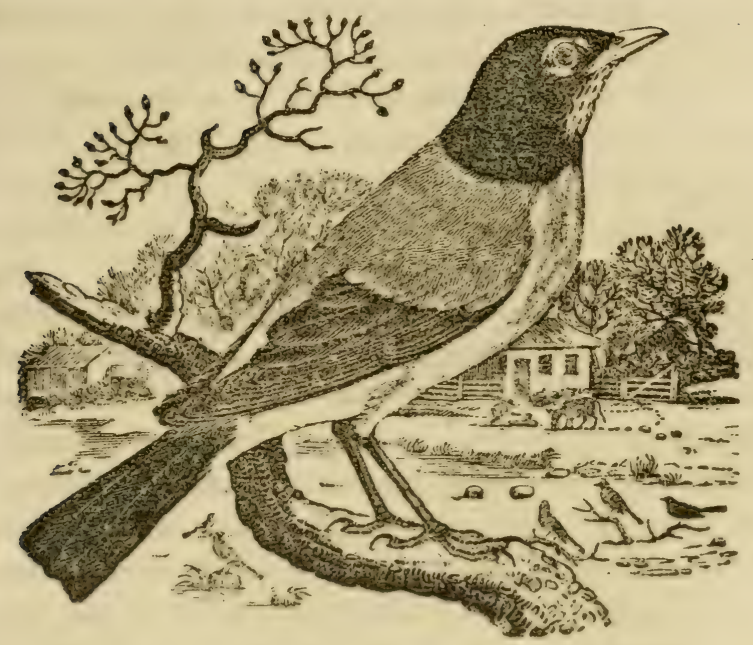

AMERICAN ROBIN.

The American Robin (Turdus migratorius) is found in California and Oregon.

"From the petulant and reiterated chirp so commonly uttered by the Robin, when surprised or irritated, the Indians of Hudson Bay, call him, from this note, Pee-pee-tshu. They often, also, utter a loud echoing, ' $k h ' k h$ ' $k h$, and sometimes chirp in a high or sleniler tone when alarmed, and with an affectation of anger sharply flirt the tail and ends of the wings. They raise several broods in a season, and considerable numbers flock together in the latter end of summer and autumn. When feeding on cherries, poke, sassafras, and sour-gum berries, they are so intent as to be easily appioached, and shot down in numbers; and when fat, are justly esteemed for food, and often brought to market. In the spring they fre- 
quently descend to the ground in quest of worms and insects, which then constitute their principal support.

"They are commonly brought up in the eage, and seem very docile and content. They sing well, readily learn to imitate lirely parts of tunes, and some have been taught to pipe forth psalms even to so dull and solemn a measure as that of "Old Hundred!" They acquire also a considerable taste for mimickry, imitating the notes of most of the birds around them, such as the blue bird, pewee, whip-poor-will, and others. On being approached with the finger, they usually make some show of anger, by cracking and snapping the bill. At times they beeome very tame, and will go in and out of the house with domestic confidence, feel uncasy when left alone, and on such occasions, have sometimes the sagacity of calling attention by articulating endearing words, as, pretty, pretty, \&c., connecting, apparently with these expressions, their general import of attentive blandishment. They become almost naked in the moulting season, in which they appear to suffer considerably, yet have been known to survive for seventeen years or upwards. The rufous color of the breast becomes deeper in those birds which thus live in confinement. Their principal song is in the morning, and commenees before sunrise, at which time it is very loud, full and emphatic.

"This bird, according to Richardson, inhabits every part of the fur countries. Fests of the Robin are found as high as the 67th parallel; and from the reports of travellers it is known to risit the northwest coast of America. It arrives in the Missouri (in lat. $11_{2}^{\circ}$,) from the eastward, on the 11th of April; and in the course of its northerly movement, visits Severn River, in Hudson Bay, about a fort- 
night later. On the 7 th of May, in 1827 , it was seen at Fort Chepewyan, in lat. $58 \frac{3}{4}^{\circ}$, and in the distant parallel of $65^{\circ}$, at Fort Franklin, on the 20 th of that inonth. In the 5-th deg:ee, they begin to hatch by the end of May; but 11 degrees farther to the north, they do not commence incubation until the 11th of June. The snow eren then partially covers the ground; but there are, in those latitudes, abundance of the berries of the alpine arbutus, crow-berry, (Empetrum nigrum, whortle-berry and cow-berry, ( $V$ accinium uliginosum, and $V$. Vitis idoa,) besides those of some other plants, which, after having been frozen up all the winter, are exposed, on the melting of the snow, again to view, full of juice, and retaining their original flavor. Dr. Richardson remarks, that the notes of the Robin "resemble those of the common thrush (Turdus musicus), but are not so loud. Within the Arctic circle the woods are silent in the bright light of noon-day, but towards midnight, when the sun travels near the horizon, and the shades of the forest are lengthened, the concert commences, and continues till six or seren in the morning. Even in those remote regions, the mistake of those naturalists who have asserted that the feathered tribes of America are void of harmony might be fully disproved. Indeed, the transition is so sudden from the perfect repose, the death-like silence of an arctic winter, to the animated bustle of summer; the trees spread their foliage with such magic rapidity, and every succeeding morning opens with such agreeable accessions of feathered songsters to swell the chorustheir plumage as gay and unimpaired as when they enlivened the deep-green forests of tropical climes, that the return of a northern spring excites in the 
mind a deep feeling of the beauties of the scason, a sense of the bounty and providence of the Supreme Being, which is cheaply purchased by the tedium of nine months winter. The most verdant lawns and cultivated glades of Europe, the most beautiful productions of art, fail in producing that exhilaration and joyous buoyancy of mind which we have experienced in treading the wilds of Aretic America, when their snowy covering has just been replaced by an infant but vigorous vegetation.' "

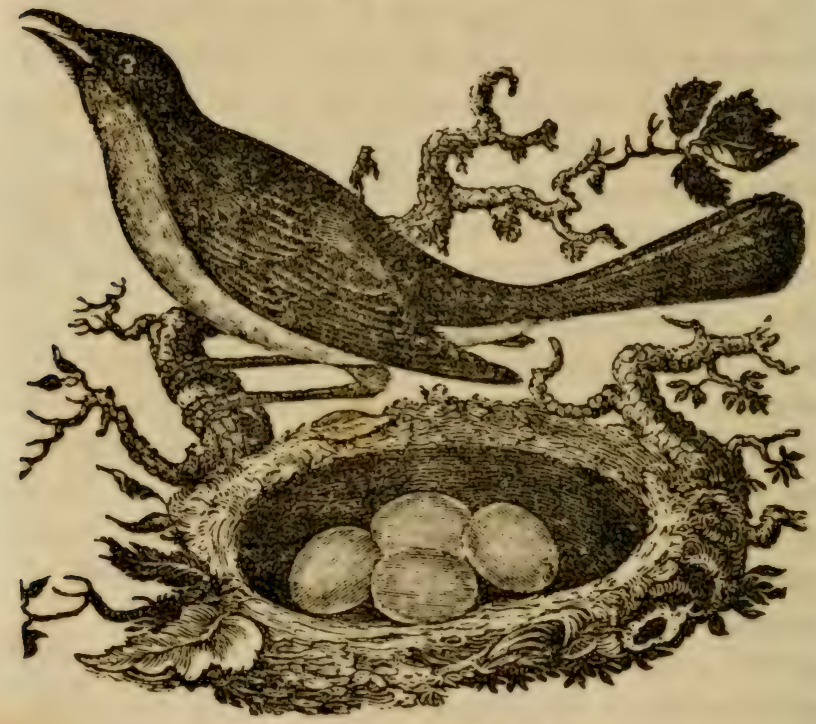

THE CAT BIRD.

The Cat Bird (Mimus Felivox) is found in various parts of California. This quaint and familiar songster passes the winter in the southern extremities of the United States, and along the coast of Mexico, from whence, as early as February, they arrive in 
Georgia. About the middle of April they are first seen in Pennsylvania, and at length leisurely approach this part of New England, by the close of the first or beginning of the second week in May. They continue their migration also to Canada; where they proceed into the fur-countries as far as the 45 th parallel, arriving on the banks of the Saskatchewan, about the close of May. They are said also to inhabit Kamtschatka, and consequently penetrate very far to the north. Throughout this extent, and to the territory of the Mississippi, they likewise pass the period of incubation and rearing their young. They remain in New England till about the middle of October, at which time the young feed principally upon wild berries.

The Cat-Bird often tunes his cheerful song before the break of day, hopping from bush to bush, with great agility after his insect prey, while yet scarcely distinguishable amidst the dusky shadows of the dawn. The notes of different individuals vary considerably, so that sometimes his song, in sweetness and compass, is scarcely at all inferior to that of the ferruginous thrush. A quaintness, however, prevails in all his efforts, and his song is frequently made up of short and blended imitations of other birds, given however, with great emphasis, melody, and variety of tone; and, like the nightingale, invading the hours of repose, in the late twilight of a summer's evening, when scarce another note is heard, but the hum of the drowsy beetle, his music attains its full effect, and often rises and falls with all the swell and studied cadence of finished harmony. During the heat of the day, or late in the morning, the variety of his 
song declines, or he pursues his employment in silence and retirement.

Of the other birds of the Thrush genus, the Brown Thrush, (Orpheus Rufus), the Varied Thrush (Turdus Nixvius), very similar to the American robin, the Wood Thrush ('Turdus Austelinus), the Dwarf Thrush (Turdus Nanus), Wilson's Thrush (Wilsonii), and the Western Thrush (Turdus Cestulatus), have all been observed by Mr. Townsend and others in Oregon and California.

Of the Sylvicola there are sereral species in this region, such as the Myrtle Bird, (Sylvicola coronata,) Audubon's Warbler (Sylvicola Auduboni), and the Summer Yellow Bird, (Sylvicola destiva.) On the geographical distribution of this bird Mr. Nuttall has the following remarks:

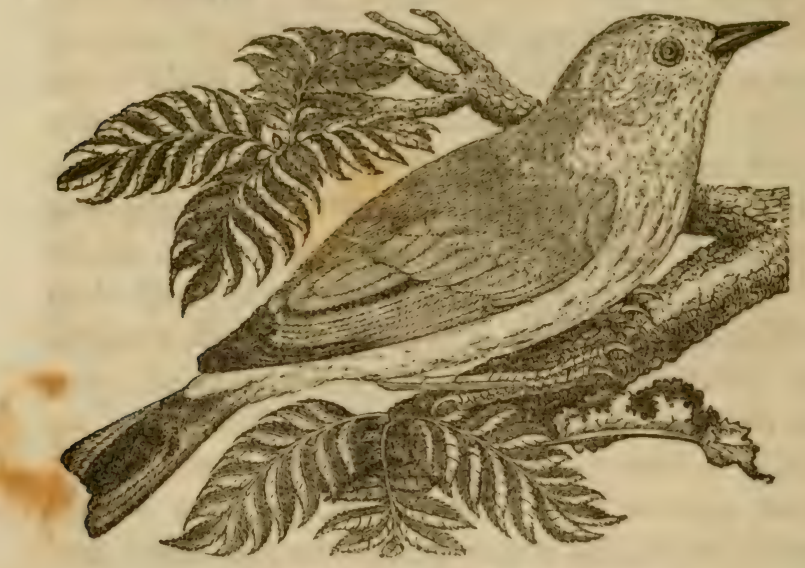

SUMMER YELLOW BIRD.

This rery common and brilliant summer species is found in all parts of the Amcrican continent from the confines of the arctic circle to Florida and Texas, as 
well as Oregon and the Rocky Mountains, where it spends the mild season. About the middle of March, I already heard their song amidst the early blooming thickets and leafy woods of the Altamaha; but they do not arrive in Pennsylvania and this part of New England before the 1st of May. About the close of August in the northern, and by the middle of September in the central States of the Union, or as soon as their second brood are capable of joining the migrating host, they disappear, probably in the twilight, and wing their way by easy stages to their tropical destination, passing through Louisiana in October, and appearing at length, about Vera Cruz, from whence they spread their numerous host through tropical America to Guiana, Cayenne, St. Domingo, and other of the larger contiguous islands of the West Indies.

Mr. Nuttall also places in California and Oregon, the Blue Mountain Warbler (Sylvicola montana), the Hermit Warbler (Sylvicola Occidentalis), Townsend's Warbler, (Sylvicola Tounsendi,) and that sweet songster, the Maryland Yellow Throat, (Trichas Marylandica.) He says in relation to the Yellow Throat:

This common and familiar species extends its summer migrations from Florida to Nova Scotia, arriving in Pennsylvania towards the middle of April, and in this part of New England about the first week in May. They return to the south in September; a few stragglers of the young, however, may be seen to the first week in October, and though some may remain and winter in the Southern States, it is more probable that the main body retire at this season into the interior of tropical America; as they were seen late in autumn, around Vera Cruz, by the naturalist and 


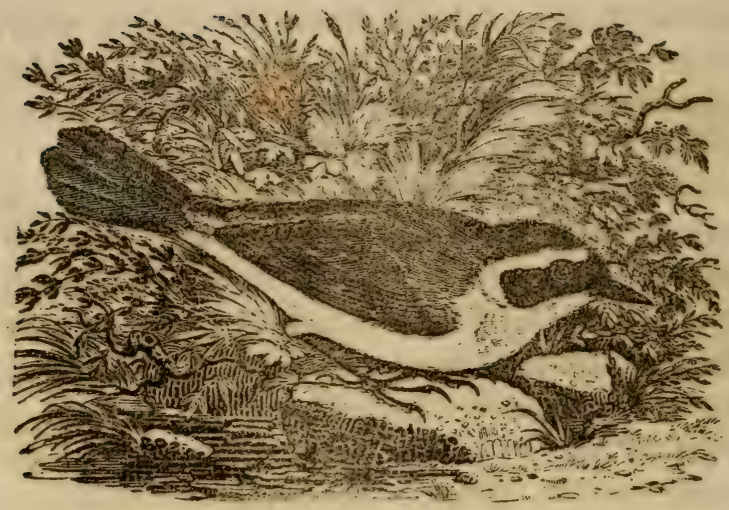

YELI,W THROAT.

traveller Mr. Bullock. Early in the month of March, however, I heard this species singing in the forests of West Florida. They also exist in the territory of Oregon, where Mr. Townsend obtained specimens. We met with them on Lewis's River, of the Shoshonee in the centre of the Rocky Mountain chain.

The Maryland Yellow Throat, with cheerful devotedness to the great object of his summer migration, the attachments and cares of his species, passes his time near some shady rill of water, amidst briers, brambles, alders, and such other shrubbery as grow in low and watery situations. Unambitious to be seen, he seldom ascends above the tops of the underwood, where he dwells busily employed in collecting the insects on which he feeds. After these, like the wren, he darts into the deepest thicket, and threads his devious way through every opening; he searches around the stems, examines beneath the leaves, and raising himself on his peculiarly pale and slender legs, peeps into each crevice in order to seize by surprise his tiny lurking prey. 


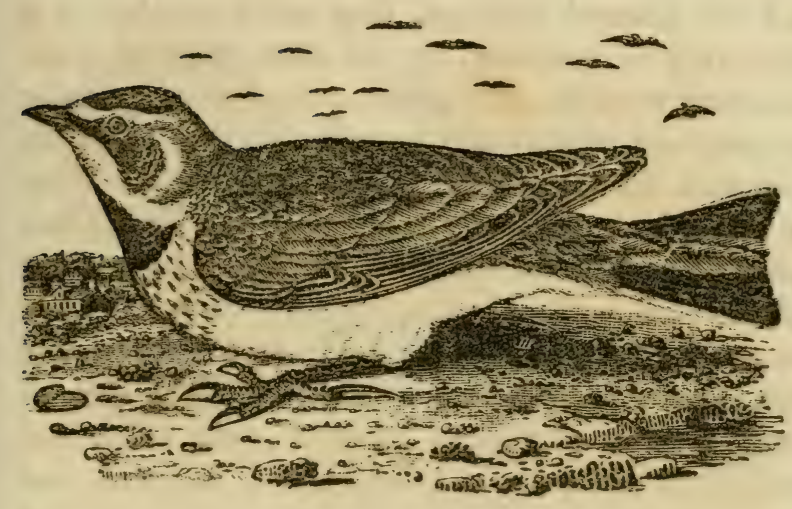

SHORE LARK.

Among the different species of Larks found in California, the must beautiful is the Shore Lark, (Alauda Alpestris.)

This beautiful species, says Nuttall, is common to the north of both the old and new continent, but, as in some other instances already remarked, the Shore Lark extends its migrations much further over A merica than orer Europe and Asia. Our bird was met with in the Arctic regions by the late adrenturous voyagers, and Mr. Bullock saw them in the winter around the city of Mexico, so that in their migrations over this continent they spread themselves across the whole habitable northern hemisphere to the very equator; while in Europe, according to the careful observations of Temminck, they are unknown to the south of Germany. Pallas met with these birds rounl Lake Baikal and on the Wolga, in the $53 \mathrm{~d}$ degree of latitude. Westward they hare also been seen in the interior of the Unised States, along the shores of the Missouri.

Inseparable in all their movements, like the hen 
and her fostered chickens, they roost together in a close ring or company, by the mere edge of some sheltering weed or tuft of grass on the dry and gravelly ground; and, thickly and warmly clad, they abide the frost and the storm with hardy indifference. They fly rather high and loose, in scattered companies, and follow no regular time of migration, but move onward only as their present resources begin to fail. They are usually fat, esteemed as food, and are frequently seen exposed for sale in our markets. Their diet, as usual, consists of various kinds of seeds which still remain on the grass and weeds they frequent, and they swallow a considerable portion of gravel to assist their digestion. They also collect the eggs and larræ of insects when they fall in their way.

The Snow Bunting (Emberiza nivalis), and the Red-winged Blackbird or Troopial (Icterus phoni$c e u s$, are found in various parts of California.

The Red-winged Troopial in summer inhabits the whole of North America from Nova Scotia to Mexico, and is found in the interior from the $53 d$ degree across the whole continent to the shores of the Pacific and along the coast as far as California. They are migratory north of Maryland, but pass the winter and summer in. great numbers in all the southern States, frequenting chiefly the settlements and rice and cornfields, towards the sea-coast, where they move about like blackening clouds, rising suddenly at times with a noise like thunder, and exhibiting amidst the broad shadows of their funeral plumage, the bright flashing of the vermilion with which their wings are so singularly decorated. After whirling and waving a little distance, like the starling, they descend as a torrent, and darkening the branches of the trees by their num- 


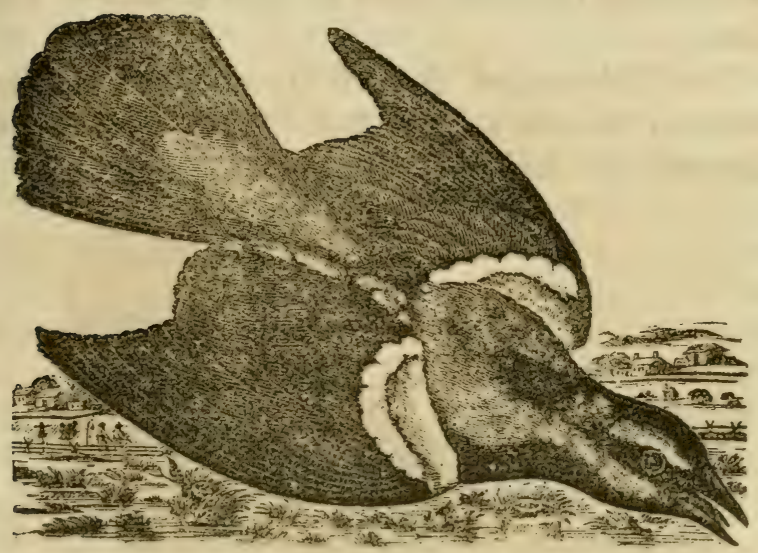

RED-WINGED BLACKBIRD.

bers, they commence a general concert that may be heard for more than two miles. This music seems to be something betwixt chattering and warbling; jingling liquid notes like those of the bobolink with their peculiar kong-quer-ree and bob a lee, o-bob a lee; then complaining chirps, jars, and sounds like sawfiling, or the motion of a sign-board on its rusty hinge, the whole constituting a novel and sometimes grand chorus of discord and harmony, in which the performers seem in good earnest, and bristle up their feathers, as if iuclined, at least, to make up in quantity what their show of music may lack in quality.

When their food begins to fail in the fields, they assemble with the purple grakles, very familiarly around the corn-cribs and in the barn-yards, greedily and dexterously gleaning up every thing within their reach. In the month of March, Mr. Bullock found them very numerous and bold near the city of Mexico, 
where they followed mules to steal a tithe of their barley.

The Whitewinged Crowbill (Loxia Leucoptera), is found in the pine and hemlock forests, subsisting on the seeds obtained from the pine cones.

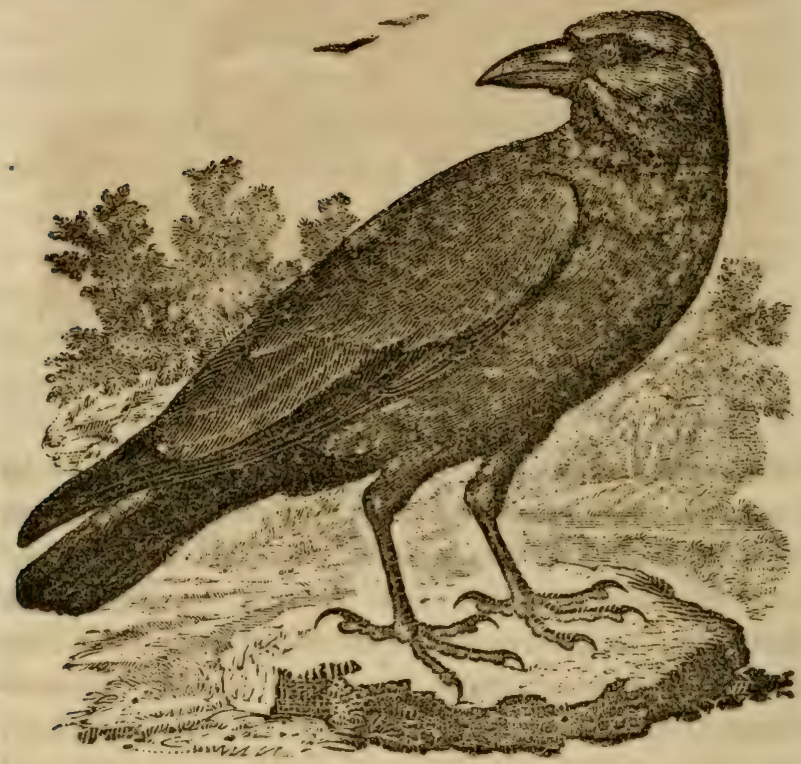

THE RAVEN.

The Raven (Corvus Corax), common to both continents is found here. Though spread over the whole world, says Nuttall, Ravens are rarely ever birds of passage, enduring the winters even of the arctic circle, or the warmth of Mexico, St. Domingo, and Madagascar. They are particularly attached to the rocky eyries where they have been bred and paired. Throughout the year they are observed together in nearly equal numbers, and they never entirely abandon this 
adopted home. If they descend into the plain, it is to collect subsistence; but they resort to the low grounds more in winter than summer, as they avoid the heat and dislike to wander from their cool retreats. They never roost in the woods like crows; and have sufficient sagacity to choose in their rocky retreats a situation defended from the winds of the north, commonly under the natural vault formed by an extending ledge or carity of the rock. Here they retire during the night in companies of fifteen to twenty. They perch upon the bushes which grow straggling in the clefts of the rocks; but they form their nests in the rocky crevices, or in the holes of the mouldering walls, at the summits of ruined towers; and sometimes upon the high branches of large and solitary trees. After they have paired, their fidelity appears to conEinue through life. The male expresses his attachment by a particular strain of croaking, and they are often observed caressing by approaching their bills, with as much scmblance of affection as the truest turtle doves.

The Crow (Corvus corone) is also abundant in California. The Magpie (Corvus pica) is a California bird.

This bird, says Nuttall, is much more common in Europe than in America, being confined in this country to the northern regions, and to the plains and table lands or steppes of the Rocky Mountains west of the Mississippi. Thence they continue to the banks of the Columbia, and on the opposite side of northern and temperate Asia, are found in Kamschatka, Japan, and Clina. They are sometimes met with as far down the Nissouri as Boonsborough in the severity of winter, driven from the western wilderness, only by the imperious calls of hunger. In 


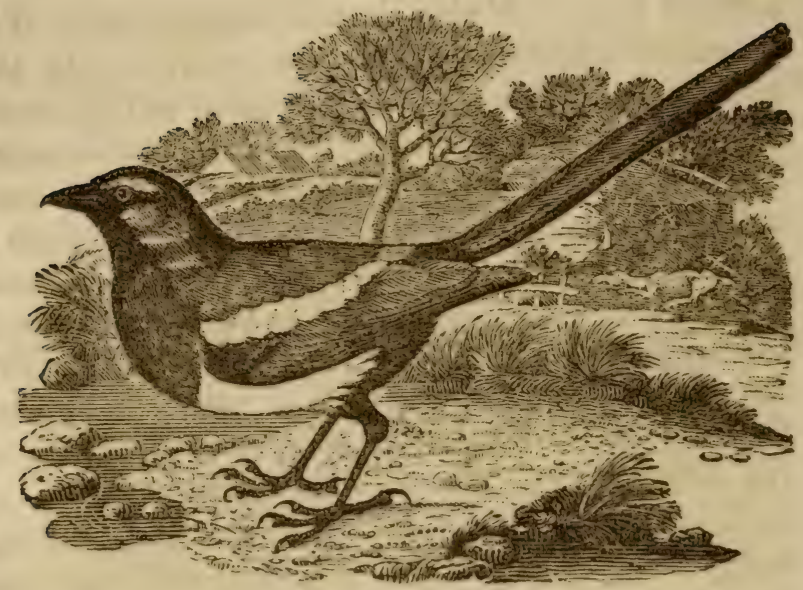

THE MAGPIE.

summer they are so rare, even in the Missouri territory, that from March to October, and from St. Louis to the trading house at the Mandans, a distance by the river of sixteen hundred miles, a party of near screnty men, attended by constant hunters, never met with a single Pie, nor were any appearances of their nests any where visible. Eleven hundred miles up the Arkansas, and more than one thousand up the Red River, countries which I risited in summer, never presented a specimen of this otherwise familiar and roving bird. The season of incubation with the American Pies, so different from their familiar habits in the old continent, is passed, no doubt, in the wooded recesses of the Rocky Mountains, which abound with berries and acorns, and with small birds and their eggs. They are known to make so great a destruction among the eggs of grouse, pheasants, partridges, and even among young chickens, in many parts of 
Europe, as to be proscribed by law, and destroyed for the premium justly set upon their heads. The absence of food and shelter for their nests in summer, suitable for the Magpie, on the vast prairies of the Arkansas and Missouri, particularly in the dry deserts at the base of the Rocky Mountains, will probably continue as a perpetual barrier to the eastern migrations of this mischievous species, whose means of flight and travelling are still more circumscribed than those of the common crow. They consequently experience annually, in the terrible vicissitudes of climate incident to the countries they inhabit; like the Esquimaux of the Arctic regions, either a feast or a famine, and are rendered so bold and voracious by want, that in the vicinity of the northern Andes, towards New Mexico, Colonel Pike was visited by them in the month of December, in latitude $41^{\circ}$, while the thermometer was at the dreadful line of $17^{\circ}$ below zero, on the scale of Reaumur. They now assembled round the miserable party in great numbers for the purpose of picking the sore backs of their perishing horses, and, like the vulture of Prometheus, they did not await the death of the subjects they tormented, but fed upon them still living, till their flesh was raw and bleeding. They were so bold and familiar as to alight on the men's arms, and eat flesh out of their hands.*

To the party of Lewis and Clark, the Magpies were also very familiar and voracious, so that they penetrated into their tents, and without ceremony, like the harpies of Virgil, snatched the meat even from the dishes, preferring the chance of any death 


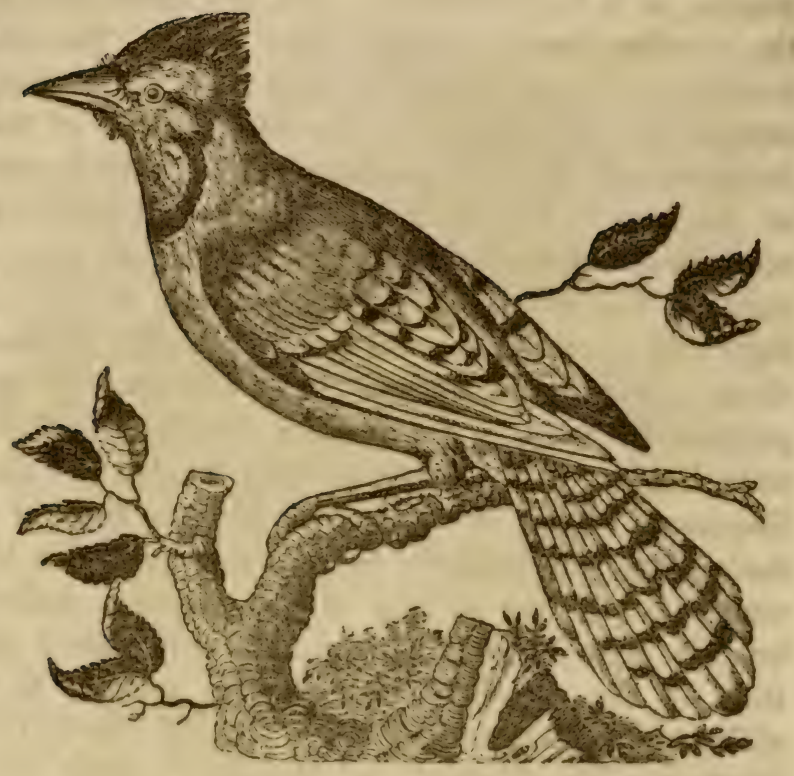

BLUE JAY.

to that of hunger. They were also frequent attendants on the hunters, and while these were engaged in dressing and skinning their game, the Pies would venture to scize the meat suspended within a foot or two of their heads.

The Blue Jay (Garrulus cristatus) and the (Garrulus Stelleri) according to Farnham, are quite common. Of the Woodneckers, the (Colaptes Mexicanus), and the Flicker or Golden-winged Woodpecker, (Colaptes auratus), are the only ones found in California.

The latter breeds and inhabits throughout North America, from Labrador and the remotest wooded regions of the fur countries to Florida, being partially migratory only from Canada and the Northern States, 


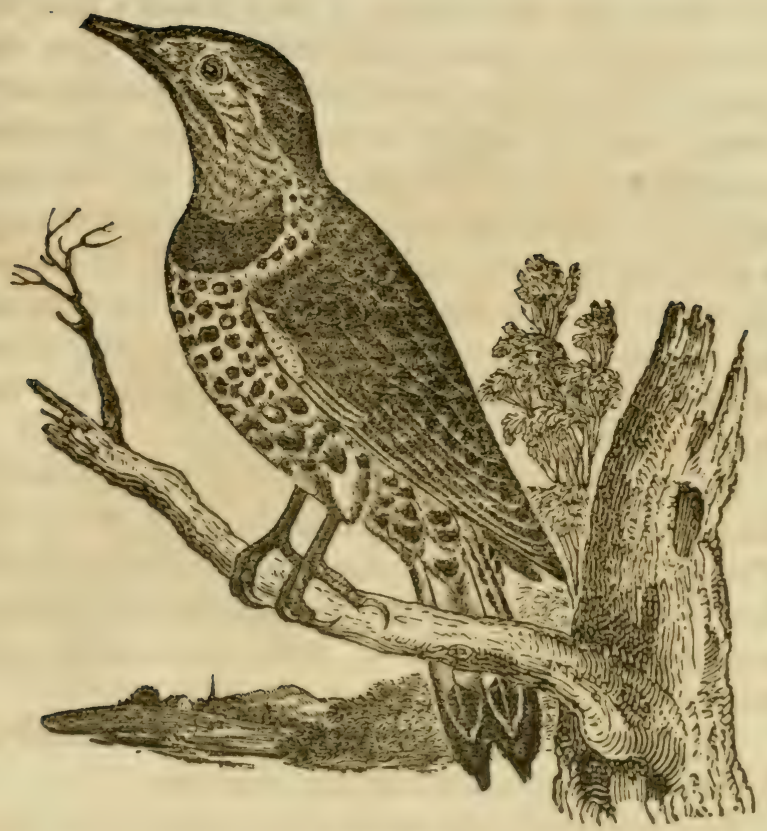

FLICKER.

proceeding to the south in October, and returning north in April. From the great numbers seen in the Southern States in winter, it is evident that the principal part of the specics migrate thither from the North and West to pass the inclement season, which naturally deprives them of the menns of acquiring their usual sustenance. At this time also they feed much on winter berries, such as those of the sumach, smilax, and misseltoe. In the Middle States, some of these birds find the means of support through the most inclement months of the winter. In New England, they reappcar about the beginning of April, soon after which they commence to pair and build; for this pur- 
pose they often make choice of the trunk of a decayed apple or forest tree, at different heights from the ground. When an accidental cavity is not conveniently found, confident in the formidable means provided them by nature, with no other aid than the bill, they have been known to make a winding burrow through a solid oak for fifteen inches in length. At this labor, for the greater security and privacy, they continue till late in the evening, and may be heard dealing blows as loud and successive as if aided by the tools of the carpenter.

Mr. Farnham says that he saw but two species of Humming Birls in California. One of these, the Trochilus rufus, he describes as a delicate, splendid little creature, less than the common species, and the most perfect gem in nature. When glancing through the trees it resembles the flash of a large ruby.

The Northern Humming Bird (Trochilus colubris) is the other kind noticed by Mr. Farnham.

This wonderfully diminutive and brilliant bird, says Nuttall, is the only one of an American genus, of more than one hundred species, which rentures beyond the limit of tropical climates. Its approaches towards the north are regulated by the advances of the season. Fed on the honeyed sweets of flowers, it is an exclusive attendant on the varied bounties of Flora. By the 10th to the 20th of March, it is already seen in the mild forests of Louisiana, and the warmer maritime districts of Georgia, where the embowering and fragrant Gelscmium (Carolina Jessamine), the twinleaved Bignonia, and the white-robed Mylocarium, with a host of daily expanding flowers, invite our little sylvan guest to the retreats he had reluctantly forsaken. Desultory in his movements, roving only 


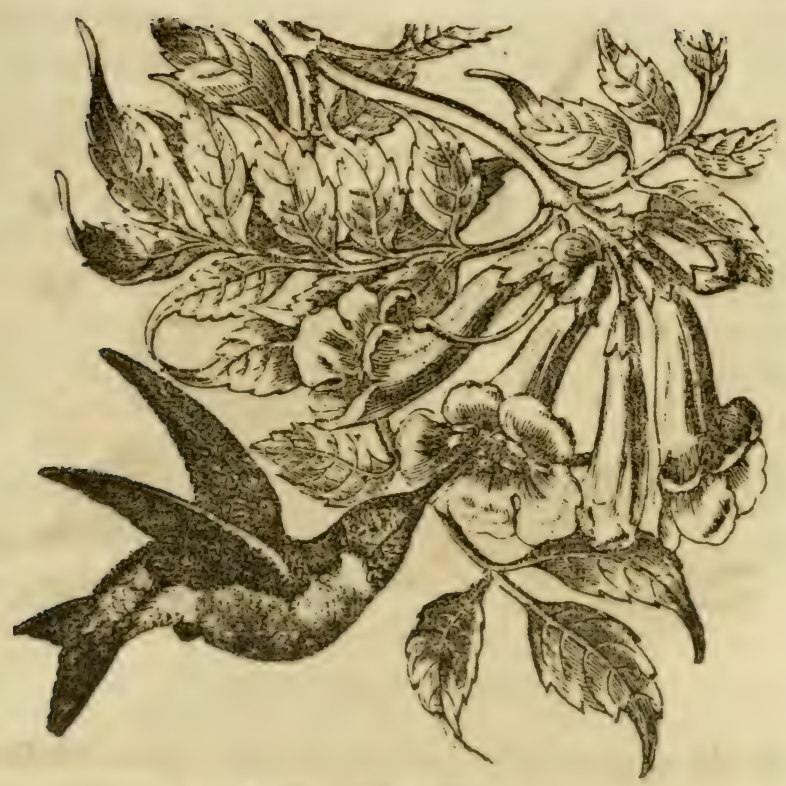

NORTHERN HUMMING BIRD.

through the region of blooming sweets, his visits to the Northern States are delayed to the month of May. Still later, as if determined that no flower shall "blush unseen, or waste its sweetness on the desert air," our little sylph, on wings as rapid as the wind, at once launches without hesitation into the flowery wilderness which borders on the arctic circle. According to Richardson, this species frequents the fur countries up to the 57th parallel, and Mr. Drummond found a nest of the IHuming Bird near the sources of Elk River in the remote interior of the north, and we met with it on Lewis's River of the Shoshone, in the latter part of July.

Of Swallows, Mr. Farnham mentions the Cliff 


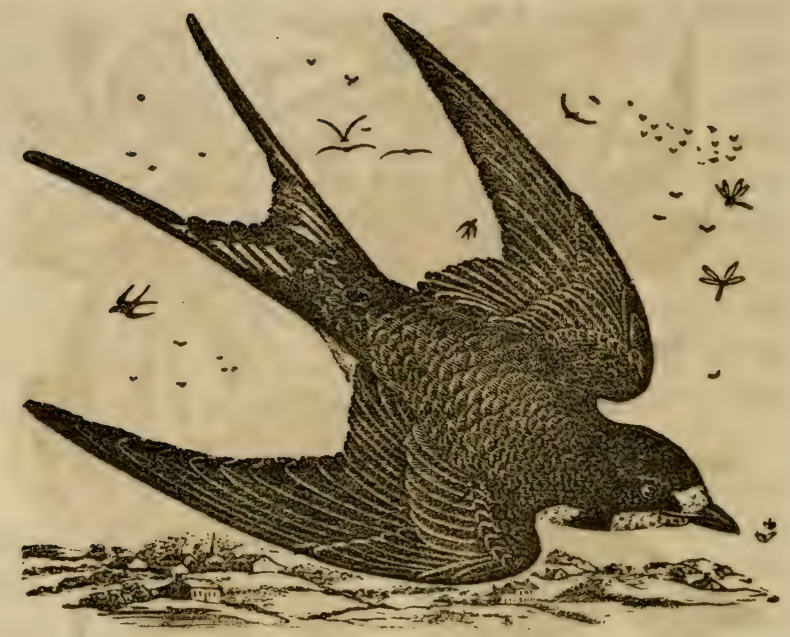

THE BARN SWALLOW.

Swallow (Hirundo Lunifrons), the Bank Swallow (Hirundo riparia), and the Barn Swallow (Hirundo Americana.) Of this bird Mr. Nuttall says:

Their northern migration extends to the sources of the Mississippi, the Rocky Mountains, and the fur countries, where distant from the habitations of man. they inhabit caves, particularly those in the limestone rocks. They retire from Massachusetts about the 18th of September, and are observed, in the same month and in October, passing over the peninsula of Florida on their way to tropical America, where they probably pass the winter. I have seen a straggling pair in this vicinity even on the 15th of October. In the months of January and February the common Chimney Swallow of Europe has been observed to moult, by Mr. Pearson of London, and Mr. Natterer of Vienna; with the latter they survived in cages, to 
which they are easily reconciled, for eight or nine years, and showed no propensity to torpidity. The fleetness with which they move, and the peculiarity of their insect fare, are circumstances which would impel a prompt transition to more favorable climates. Accidental fits of torpidity, like those which occasionally and transiently take place with the Humming Bird, have undoubtedly happened to Swallows, without proving any thing against the general migrating instinct of the species.

The Kingfisher (Aleedo Alcyon), is very common on the banks of the rivers and water-courses of California. The Night Hawk (Caprimulgus Virginianus), is also common.

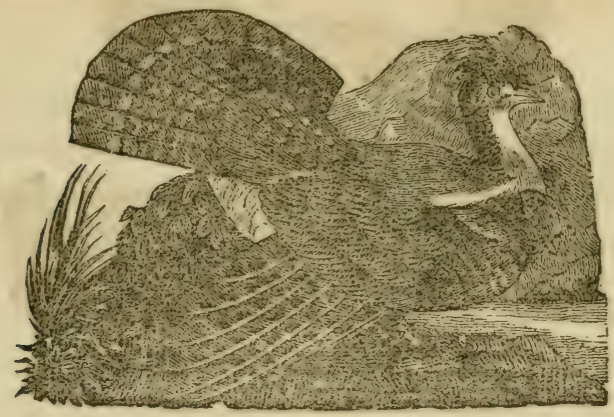

RUFFED GROUSE.

Mr. Farnham says that there is probably no country in the world which produces so many rarieties of the Grouse, and in so great numbers as California. The Great Cock of the Plains (Tetrao Lrophasianus), second only in size and beauty to the cock of the woods of Europe, is plentiful in Northern California. $\mathrm{He}$ is thirty inches long, nearly four feet in extent, and weighs from seven to ten pounds. The Dusky 
Grouse (Tetrao Obscurus), less than the preceding in size, and the Rock Grouse (Tetrao rupestris), is also common in the mountainous regions. Also the Ruffed Grouse (Tetrao umbellas), called in the Southern States, Pheasant, and in the Northern States, the Partridge, is found here. The White-tailed Grouse (Tetrao Leucurus), is common in different places, as also the Pinnated Grouse (Tetrao cupido,) called the Prairie Hen, of which species the male has a singular wing-like appendage to the neck.

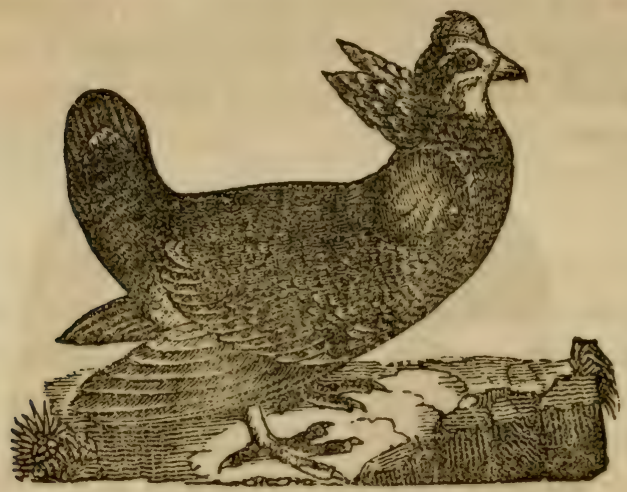

PINNATED GROUSE.

There are also several species of the Quail in California. Of the common Quail, called in the Middle States the Partridge (Ortyx Virginana), Nuttall says :

The Partridge of America, exceedingly prolific, has extended its colonies from the inclement coasts of New England and the western plains of Missouri to the mild latitudes of Mexico and Honduras. In Jamaica, where it has long been introduced and naturalized, the inhabitants distinguish it as the Partridge, an appellation sufficiently prevalent in various parts 


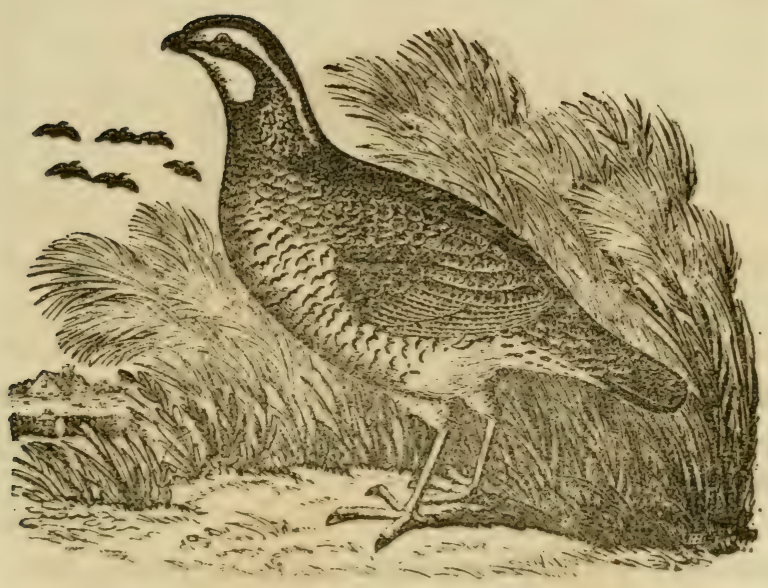

QUAIL.

of the United States. At the north, this species is rarely seen to the extremity of New Hampshire, and this limit, no doubt, is determined by the length and severity of the winters which prevail in this rigorous climate. They seldom migrate, except to short distances, in quest of food, and consequently, often perish beneath deep drifts of snow, so that their existence is rendered impossible in the arctic winters of our high latitudes. Indeed, sometimes they have been so thinned in this part of the country, that sportsmen, acquainted with their local attachments, have been known to introduce them into places for breeding and to prevent their threatened extermination. So sedentary are the habits of this interesting bird, that until the flock is wholly routed by the unfeeling hunter, they continue faithfully attached to the ncighborhood of the spot where they have been raised and supported. Besides this species there are several which appear 


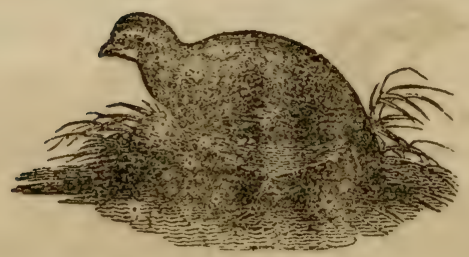

CALIFORNIA QUAIL.

to be peculiar to California. The California Crested Quail (Lophortyx Californica), is thus noticed by Nuttall:

This species, discovered by Menzies, is wholly confined to the west side of the northern Andes, and is common throughout the provinces of Upper California, and the territory of the Oregon.

In small flocks and pairs they are abundant in Upper California, and are sometimes so gentle and confidant, as to show but little alarm when approached. Its manners are very similar to those of the common Americar Partridge. The males in spring are often seen perched on low bushes, where they utter for hours their peculiar almost crowing call, and in the same quaint voice with its eastern prototype.

A day or two after my arrival at Monterey in California, in the evening, returning from a walk, I heard, as I thought, some Indians or boys calling out in a loud s'rain; but soon found that this cry was answered at small distances like the erowing of fowls. It was, in fact, the cal of the Tufted Californian Quail, "k'h,k'hk'hkh." About the middle of April, in the plains round the port of St. Diego, this species was re:y abmiant; and ere:y now and then in the day, the male, perched on some low bush or hillock, 
was heard calling out, rather quickly, ke kai koo, likaikoo, which was usially answered by some other males, to the right and left, who were within hearing. At this time they were paired. About the middle of the day, we sometimes surprised small flocks basking and scratching in the shade of the bushes.

Mr. Townsend met with small coveys of the Plumed Quail (Lophortyx Plumifera), in the woods near the Columbia River. It is probably more common in Cpper California; and Douglas's Crested Quail (Lonliortyx Douglasi), and the elegant crested Quail Lophortyx elegans, have both been found in Cpper California.

The bays, inlets, and rivers, says Mr. Farnham, are well stocked with difierent species of water birds, and the low lands near the outlets of some of the streams on the Pacific coast actually swarm with geese, widgeons, teal, cranes, curlews, snipes, and various other waders and swimmers.

The Wild Swan (Cygnus ferus), is the largest of these water birds. They are by far the largest of the web-footed water-fowl, and their plumage throughout is of the purest white. The neck is not more remarkable for its extreme length than for its majestic personation of the line of beauty; its bill, slightly hooked at the point, of a black color, without a tubercle, is all of an equal breadth, only higher than it is wide at the base; the feet are black. The young, pale ash color. The male is upwards of five feet in length, and more than eight in the expanse of its wings; its usual weight averages from twenty to twenty-five pounds, and somctimes it will even reach thirty; the female is smaller in size. In former days, swans as well as peacocks were served up at the tables of the great; 


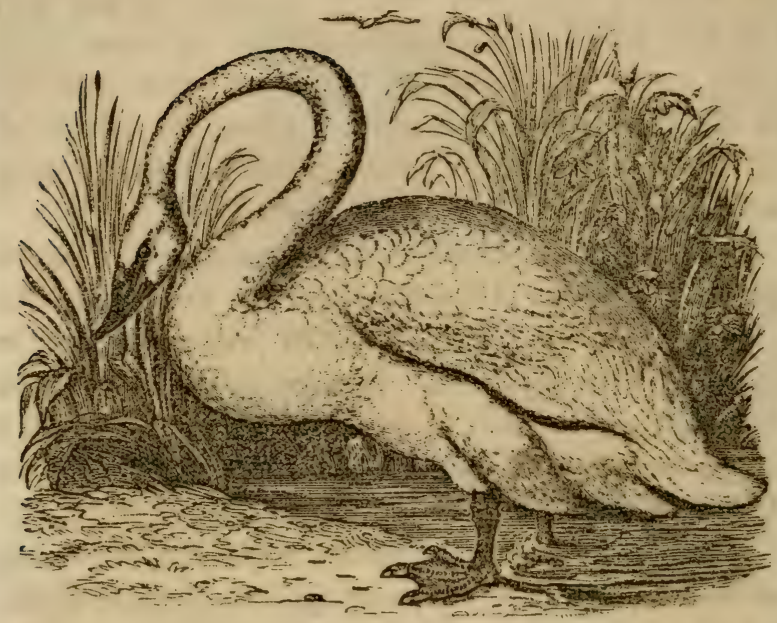

WILD SWAN.

but both have now disappeared from our feasts, and are retained only for their beauty, their flesh at best being dry and hard when the birds are full-grown; yet cygnets are still occasionally used, but certainly more for show than taste, as they are not at all comparable to a good barn-yard chicken. The swan is a longlived bird, but it is disputed whether the traditionary accounts which allot it a term of more than a century be correct; about half that period may perhaps be its legitimate boundary. The Swan lives almost entirely upon the water, and feeds chiefly upon aquatic plants, yet varying its vegetable diet with frogs and insects.

The Trumpeter $S$ wan (Cygnus buccinator), is more common. It is from this kind that the bulk of the swan-skins imported by the Hudson Bay Company are obtained. Douglas mentions a third kind equal in 
size to the common swan, and of a bluish-gray color on the back and white on the belly.

Mr. Farnham gives the following species of geese. The Laughing Goose (Anser albifrons), the Snow Goose (Anser hypoboreus), the Common Wild Goose (Anser Canadensis), and the Brant Goose (Anser bernacla.)

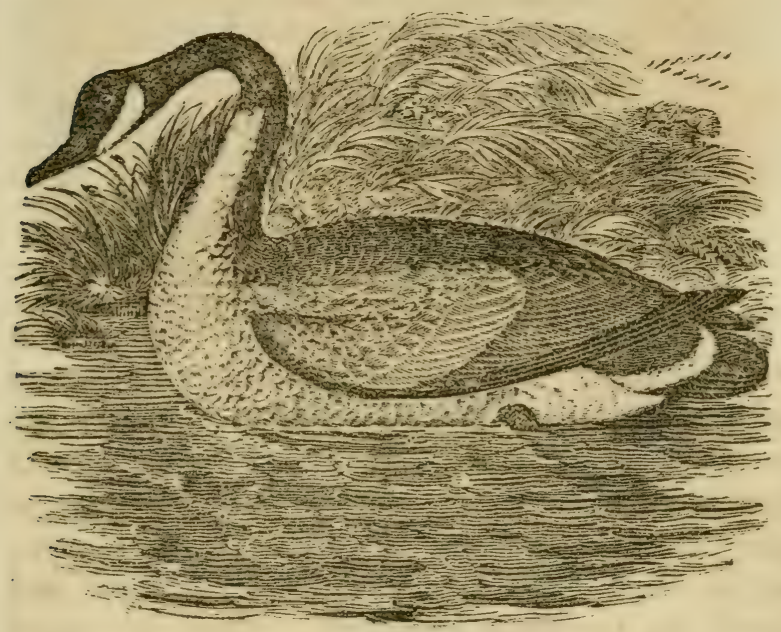

THE COMMON WILD GOOSE.

The Common Wild Goose, or Canada Goose, is larger than the tame goose, and slender in its make. The back and upper parts of the body are brown, with white spots; the head and neck black, with a conspicuous white patch on the throat and lower part of the cheeks; the bill is black and the feet lead colored. It is not, however, confined to Canada, but extends its migrations from the southernmost borders of the United States to the most northern points that 
have been reached by man; and they are marked by the swiftness of their flight, and the height to which they soar:

"Vainly the fowler's eye, Might mark thy distant flight, to do thee wrong;

As darkly painted on the crimson sky.

Thy figure floats along.

"Seek'st thou the plashy brink,

of weedy lake, or merge of river wide;

Or where the rocking billows rise and sink

()n the chaffed ocean side;

"There is a Power, whose care

Teaches thy way along the pathless coast,

The desert and illimitable air,

Lone wandering, but not lost.

"Thou'rt gone! thy abyss of heaven

Hath swallowed up thy form!"

If few, they fly in one line, but if numerous, in two, converging to a point like the letter A turned upside down, and they are always led by an old experienced gander. They make their appearance in Hudson Bay in spring, going north, where great quantities are taken, and salted for a winter's store; and on their return in winter, they are killed and frozen up for fresh provisions. They are easily domesticated, and readily pair with the common gray goose; but their wings must be cut to prevent their absconding, for on the approach of spring they are always observed to become restless and uneasy, frequently looking up into the air, making attempts to fly away, and hailing every flock of their wild brethren that passes over their heads, who always acknowledge and return the salute.

The Barnacle Goose, or Brant Goose, is common to the northern regions of both continents, emigrating to more temperate climates in autumn and winter. 


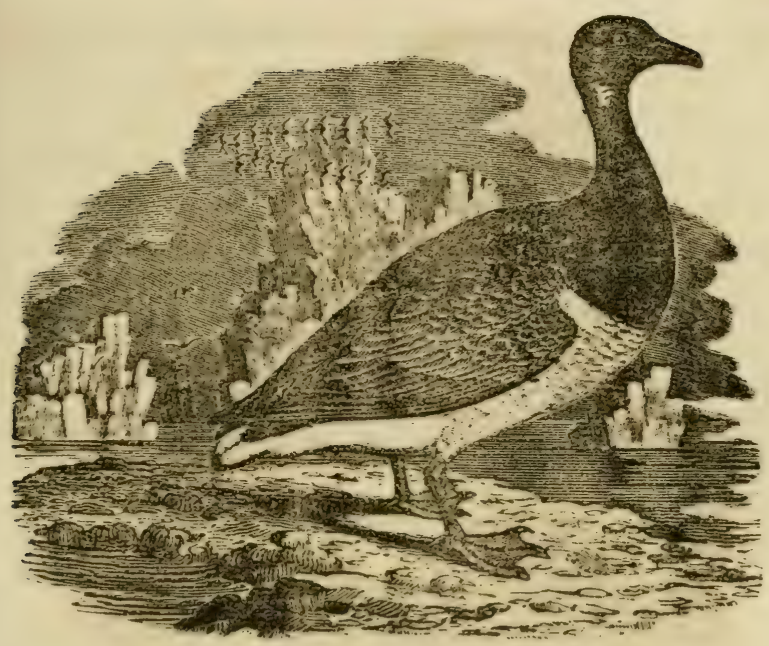

BRANT GOOSE.

The most ridiculous fables have been invented concerning the origin of this bird, which was long beliered to be the produce of a kind of shells, hence called conche anatiferce, found on certain trees on the coast of Scotland and the Orlineys, or on the rotten timber of decayed ships. Abundance of authority for this absurd fiction may be found in the old books of natural history.

The White Pelican (Pelicanus Onocrotalus), is sometimes seen on various parts of the coast. This bird is as large as a swan, measuring, when fully grown, from five to six feet from the point of its bill to the tip of its tail. Its bill, which stretches to sixteen or eighteen inches, and two or three in breadth, forms the distinguishing singularity of this bird. The upper mandible is quite flat, with a small red hook at the point; the under consists of two pieces united at 


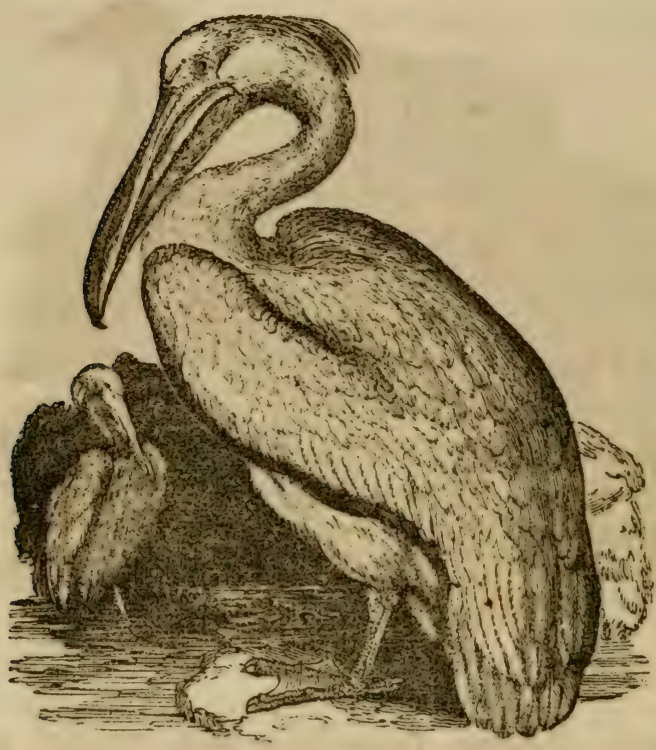

THE WHITE PELICAN.

the tip, between which is placed a large dilatable pouch, of a light straw color, that extends down the fore part of the neck, and is capable of containing, when extended, fifteen quarts liquid measure, and serving the double purpose of a reservoir and provision bag, for in this the parent fetches both food and water to its young. The neck has somewhat of the curvature of the swan, but without its majestic bearing, and is covered with a short close down; the head is bare in front, and flesh-colored, but on the back part has a tuft of feathers falling down on the neck. The body is large; the wings of a moderate size, extremely light in their bony structure, and capable of receiving a large quantity of air, which enables it to soar high and continue long on the wing; the legs are short, and. 
bare above the knee. In an adult bird, the plumage is almost entirely white, excepting the quill feathers, which are black ; but as it advances in age, it becomes tinged with light red or yellow. The White Pelican is found on the sea-shore, and on the banks of lakes or great rivers, in almost every part of the Old World, with the exception of the aretic regions. In the year 1663, a straggler was shot in England at Horsey Fen. It feeds on fish; and when a single bird is in search of prey, it wheels round and round at the height of fiftecn or twenty feet, and as soon as it perceives a fish, darts upon it with inconceivable rapidity: should it miss, it rises, and again repeats the manouvre, till it succeeds ; and, as soon as caught, it is consigned to its bag, till it accumulates a sufficient store to satisfy its voracity, with which it retires to some neighboring rock or tree to eat and digest at leisure, and to sleep till the call of hunger stimulate it to fresh exertion. Sometimes, according to Buffon, they assemble in large flocks, and exhibit no small ingenuity in collecting and securing an abundant meal. This they accomplish by forming a circular line, and gradually narrowing the inclosure, till the fishes are driven within a limited space; then, upon a given signal, they all plunge into the water at once, fill thoir wallets, and return loaded to land to satiate their gluttony. It builds in rocks, or in marshy and unfrequented places in low islands and lakes, and lays two or three white eggs. It is affectionate and attentive to its young, and from feeding it out of its pouch originated the fable of its piercing its breast and feeding them with its blood.

Off the Pacific coast may be seen the Albatross, or Man-of-War Bird, (Diomeda exulans), the biggest of all aquatic birds, frequently larger than a swan, and 


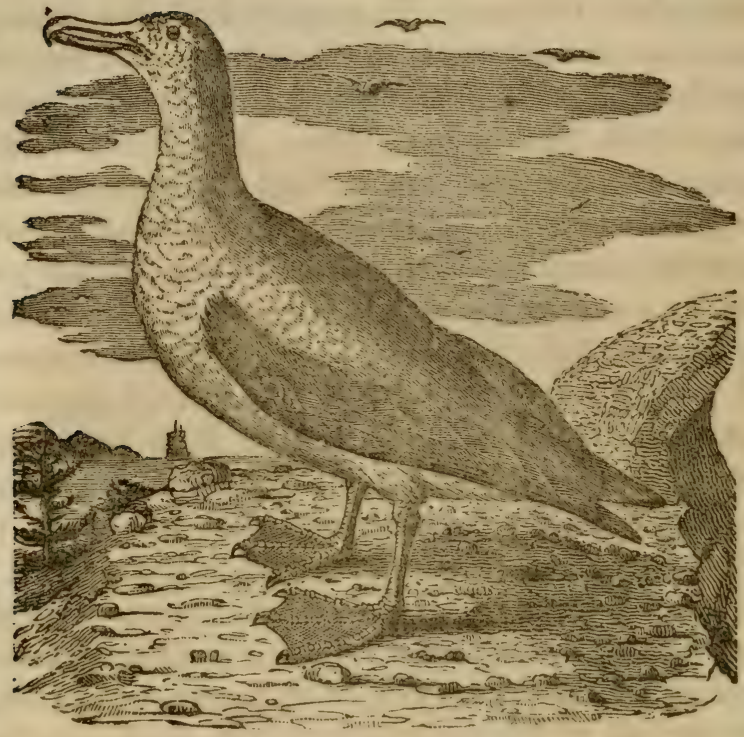

THE ALBATROSS.

has a widg range upon the ocean, both within and without tue tropies. It has a large strong yellow bill, terminated by a stout hook on the upper mandible; the plumage is white, the back and wings marked with black lines, and the feet a carnation red; it has only three toes, webbed. It is a very voracious bird, and commits great depredations on the salmon, which are found in shoals at the mouths of rivers in these countries; and it is the greatest enemy of the flying-fish, when forced to seek refuge in the air from the pursuit of its destroyers in the sea; nor are its ravages confined to the finny tribes-it makes a prey likewise of the smaller water-fowl, when it can contrive to surprise them. In return, however, it finds powerful antagonists in the sea eagle, and the skua gull, especially 
after it has gorged itself and become heary, when it sometimes pays the penalty of its gluttonizing. On the shores of South America, about the end of September, it builds a nest of earth upon the ground, from one to three feet high, and lays a number of eggs, four and a half inches long, which are eaten by the natives; its flesh is hard and dry, but it also is used for food. Its voice is said to resemble the braying of an ass.

The Sanderling Plover (Tringa arenaria), is often seen on the coast. The numerous flocks keep a low circling course along the strand, at times, uttering a

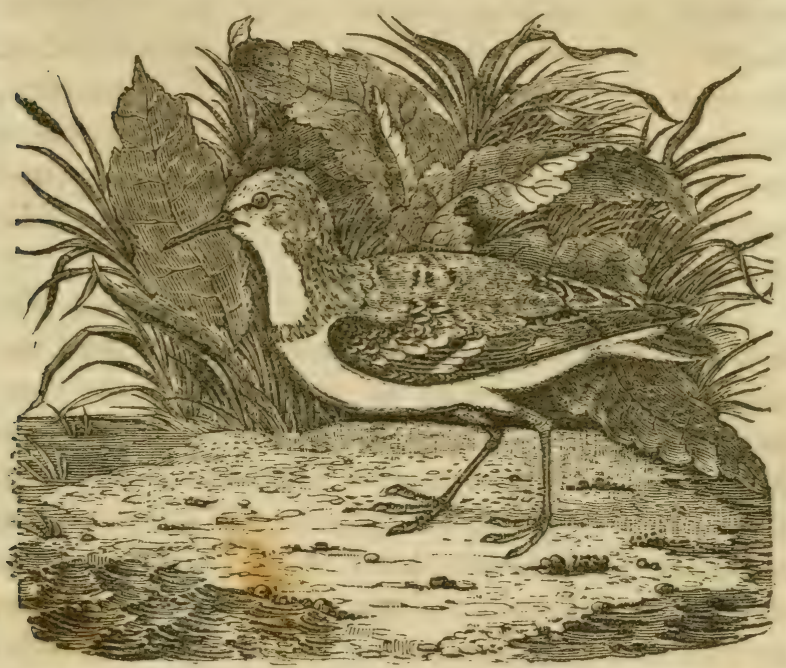

SANDERLING PLOVER.

slender and rather plaintive whistle, nearly like that of the smaller sandpipers. On alighting, the little actire troop, waiting the opportunity, scatter themselres about in the rear of the retiring surge, the succeeding wave then again urges the busy gleaners 
before it, when they appear like a little pigmy army passing through their military evolutions; and at this time the wily sportsman, seizing his opportunity, spreads destruction among their timid ranks; and so little are they aware of the nature of the attack, that, after making a few aerial meanders, the survivors pursue their busy avocations with as little apparent concern as at the first. The breeding place of the Sanderling, in common with many other wading, and aquatic birds, is in the remote and desolate regions of the north, since they appear to be obliged to quit those countries in America a little after the middle of August. According to Mr. Hutchins, they breed on the coast of Hudson Bay, as low as the 55th parallel; and he remarks that they construct, in the marshes, a rude nest of grass, laying four dusky eggs, spotted with black, on which they begin to sit about the middle of June.

The Common or Golden Plover (Charadrius pluvialis), is also found on this coast. Indeed the Common Plover is, according to the season of the year, met with in almost erery part of the world, particularly in Asia and Europe, from Kamtschatka to China, as well as in the South Sea Islands; and on the present continent from Arctic America, where it breeds, to the Falkland Islands; it is also seen in the interior, at least as far as Missouri. They breed in Siberia, and in the northern parts of Great Britain, but not in France or Italy, where they are also common. At such times, they select the high and secluded mountains sheltered by the heath, where, without much attempt at a nest, they deposit about four, or sometimes five eggs of a pale olive color, marked with blackish spots. 


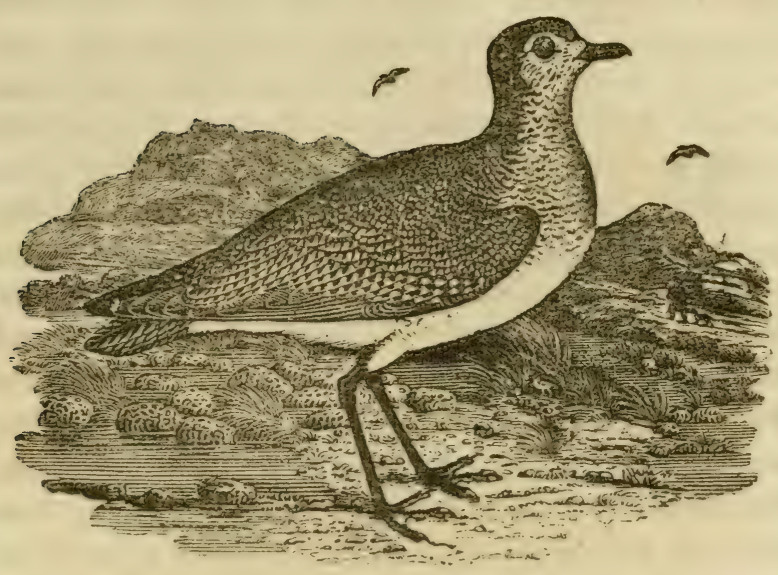

GOLDEN PLOVER.

They arrive on the coast of the Middle and Northern States in spring and early autumn. Near to Nantasket and Chelsea beach, they are seen, on their return from their inclement natal regions in the north, by the close of August, and the young remain in the vicinity till the middle of October, or later, according to the state of the weather. They live principally upon land insects, or the larrx and worms they meet with in the saline marshes, and appear very fond of grasshoppers. About the time of their departure they are, early in a morning, seen sometimes assembled by thousands, but they all begin to disperse as the sun rises, and at length disappear high in the air for the season. They usually associate, howerer, in small flocks and families, and when alarmed, while on the wing, or giring their call to those who are feeding around them, they have a wild, shrill and whistling note, and are at most times timid, watchful, and diffi- 
cult to approach. Though they continue associated in numbers for common safety during the day, they disperse in the evening, and repose apart from each other. At daybreak, however, the fecling of solitude again returns, and the early sentinel no sooner gives the shrill and well known call than they all assemble in their usual company. At this time, they are often caught in great numbers by the fowler, with the assistance of a clap-net, stretched before dawn, in front of the place they have selected to pass the night. The fowlers now surrounding the spot, prostrate themselves on the ground when the call is heard, and as soon as the birds are collected together, they rise up from ambush, and by shouts, and the throwing up of sticks in the air, succeed so far in intimidating the Plovers that they lower their flight, and thus striking against the net, it falls upon them. In this, and most other countries, their flesh, in the autumn, and particularly that of the young birds, is esteemed as a delicacy, and often exposed for sale in the markets of the principal towns.

The Cinereous Coot (Fulica Americana) appears here among the water birds. This bird, says Nuttall, is found in almost every part of the continent, from the grassy lakes that skirt the Saskatchewan plains, in the 55th parallel, to the reedy lagoons of East Florida, and the marshes of Jamaica. To the West, the species seems to inhabit the waters of the Columbia, in the remote territory of Oregon. Mr. Say observed them also in the lower part of Missouri, and in Long's Expedition, they were seen in Lake Winnipique (lat. $42^{\circ}$ ), on the 7 th of June. Mr. Swainson has also received specimens from the distant table-land of Mexico. We may, therefore, conclude almost with certainty, that the Coot of 


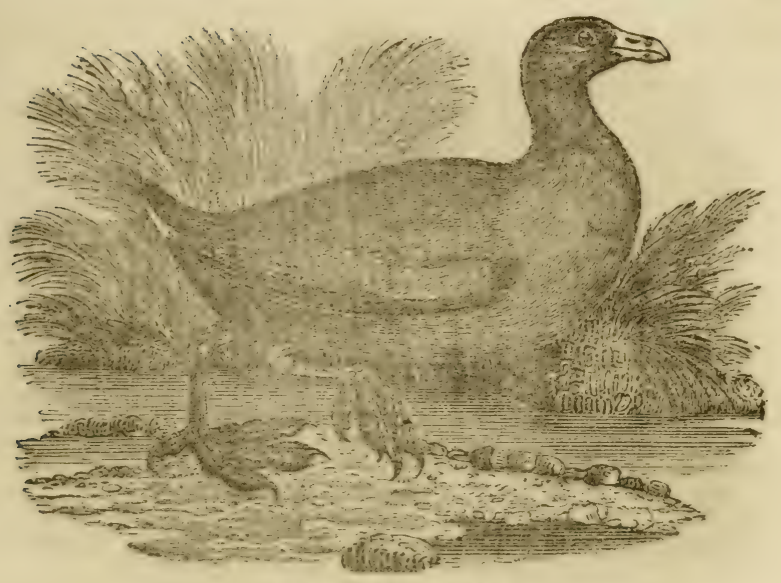

CINEREOTS COOT.

America, indifferent to climate, dwells and breeds in every part of the North American continent, over a range of probably more than fifty degrees of latitude! Nocturnal in their habits, and dispersing themselves far and wide orer every water solitude, they appear, in many places, to hare disappeared for the season, until the numbers, swelled by their prolific lroods, and impelled at the approach of winter to migrate for food, now begin to show themselves in the lakes, pools, and estuaries in the ricinity of the sca, from which they gradually recede towarls the south, as the sererity of the season compels them, being unable to subsist amidst the ice. In this way they proceed, accumulating in numbers as they adrance, so that in the inundated and marshy tracts of Florida, particularly along the banks of the San Juan, they are seen in winter, congregated in rast and noisy flocks. In the milder latitudes, their whole migrations will be limited to a traverse from the interior to the vicinity of the 


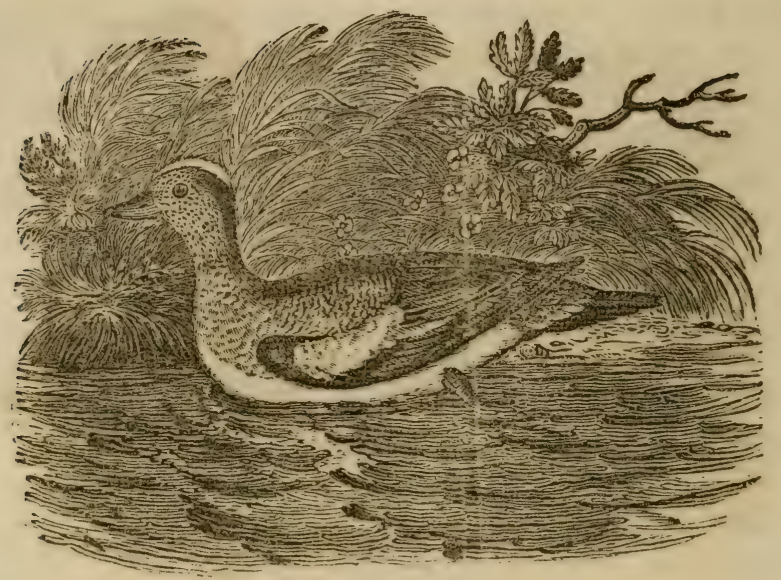

THE WIDGEON.

sea, while those which visit the wilderness of Upper Canada, where they are abundant in the summer, will probably migrate from twenty-five to thirty degrees every spring and autumn.

The Widgeon, or Bald-Pate (Anas Americana) is another California game bird.

The Widgeon, or Bald-Pate, is a frequent attendant on the canvas-back, and often profits by this association. The former, not being commonly in the habit of diving for subsistence, or merely from caprice, watches the motions of its industrious neighbor, and as soon as the canvas-back rises with the favorite root on which they both greedily feed, the Bald-Pate snatches the morsel and makes off with his booty. They are always very alert and lively, feeding and swimming out into the ponds and rivers at all hours of the day, but are extremely watchful, sheltering in cores and behind the land, and on the slighest attempt to steal upon them, immediately row out into the 


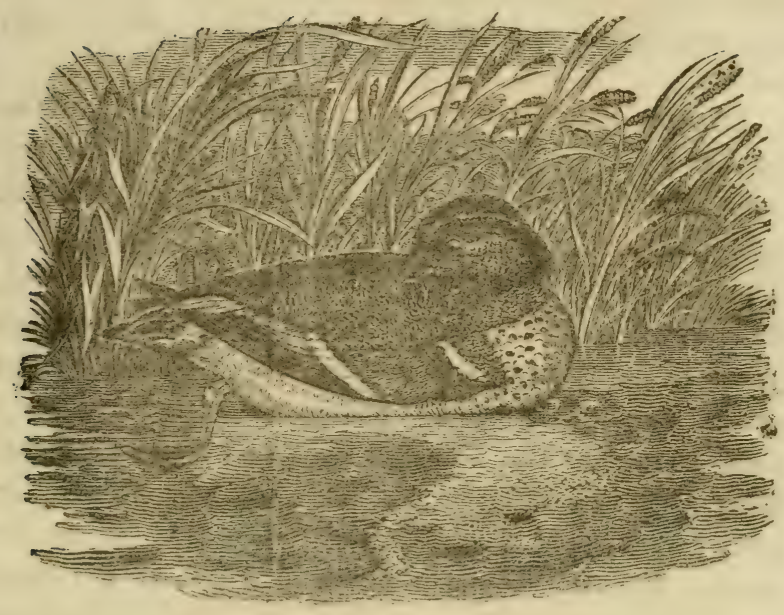

AMIRICAN TEAL.

هiream beyond gun-sìot, and then only take to wing when much disturbed.

The American Teal (Anas crecca, is another valuable game fowl.

They are commonly secn on the pools, in close companies of ten or twelve together, frequenting the rivers and unfrozen springs in winter, where they subsist an aquatic plants. Thoy fly very swiftly, and utter a sort of whistling cry. The Teal breeds in the fens, continuing in the tempcrate parts of Europe the whole year. It conceals its nest among the bulrushes, constructing it of their stalks, and lining it with feathers; it rests also sometimes on the surface on the water, so as to rise and fall with the flood. The cgrgs are about ten or twelre, of a soiled white, indistinctly marked with brown spots. The female takes the whole man$31 *$ 
agement of incubation; the males, at this time, seem to leave them and associate by themselves in companies.

Another interesting specimen of the duck is the Golden Eye (Fuligula Clangula.) The Golden Eye* is a common inhabitant of the boreal regions of both continents, from whence it migrates in small flocks at the approach of winter, accompanying the velret, surf duck, and scoter, in their desultory route in quest of subsistence. On their way, soon after the commencement of their adventurous royage, they visit the shores of Hudson Bay, and their congenial lakes in the interior, on which they linger, feeding on tender and small shell-fish, until debarred by the invasion of frost. They breed in all parts of the desolate and remote fur countries in great numbers, frequenting the rivers and fresh-water lakes, on whose borders they pass the period of reproduction, making a rude nest of grass, and protecting the necessary warmth of their eggs by a layer of feathers or down plucked from the breast. According to Linnæus it lays from seven to ten white eggs, which it often conceals and protects with its nest in hollow trees. And Skioldebrand adds, that in common with the velvet duck, it breeds abundantly in Lapland, on the banks of the Tornea, within the Arctic circle, and nearly to the northern extremity of Europe. The inhabitants, for the value of the eggs, take the trouble to accommodate these useful and almost domestic birds, by attaching hollowed pieces of wood to the stunted pine trees in which they ordinarily breed. They extend their summer residence as far as Northern 
Asia and Greenland, yet in Europe some pairs are observed to propagate even in temperate countries.

Although furnished with a remarkably complicated trachea in the male, and the name clangula, we cannot learn that they ever possess any audible voice. When flushed they rise in silence, and we then only hear, instead of a cry or a quack, the very perceptible and noisy whistling of their short and laboring wings, for which reason they are here sometimes called by our gunners the Brass-Eyed Whistlers. In their native haunts they are by no means shy, allowing the sportsman to make a near approach, as if conscious at the same time of their impunity from ordinary peril, for no sooner do they perceive the flash of the gun, or hear the twang of the bow, than they dive with a dexterity which sets the sportsman at defiance, and they continue it so long and with such remarkable success that the aboriginal natives have nick-named them as conjuring or "spirit ducks."

The food of the Golden Eye, for which they are often seen diving, consists of shell-fish, fry, small reptiles, insects, small crustacea, and tender marine plants. In and near fresh waters they feed on fluviatile vegetables, such as the roots of Equisetums, and some species of Polygonum. Their flesh, particularly that of the young, is generally well flavored, though inferior to that of several other kinds of ducks.

The Rocky Mountain Golden Eye (Clangula Barrovii), also occurs in these regions. The habits of this species, so nearly related to the preceding, are said to be wholly similar. It has hitherto been found only in the valleys of the Rocky Mountains. Besides the permanent difference in the bill, this species is 


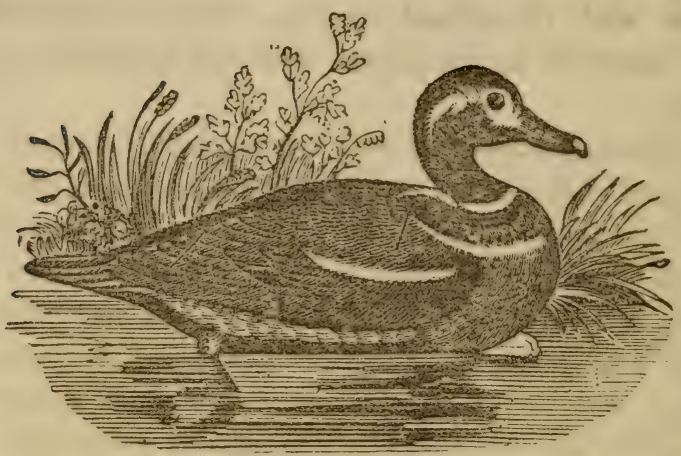

THE HARLEQUIN DUCK.

further distinguished by the purer color of its dorsal plumage, and the smaller portion of white on its wing and scapulars. Its long flank feathers are also much more broadly bordered all round with black.*

The Harlequin Duck (Fuligula Histrionica) is common to both continents. This singularly marked and beautiful species is almost a constant resident of the hyperboreal regions of the northern hemisphere, from which it migrates but short distances towards more temperate latitudes, and is as in Europe a rare and almost accidental visiter as far as the Middle States of the Union. It is however more frequent in Eastern Europe up to Greenland ; and common from Lake Baikal to Kamtschatka. Now and then it is killed in Scotland and the Orkneys. Dr. Richardson found it to be a rare bird in the fur countries, haunting eddies under cascades, and rapid streams, where it dwells and breeds apart from all other ducks. In Kamtschatka it affects the same retired and remark- 
able romantic situations; like the alpine cinclus, it seeks out the most rocky and agitated torrents, in such situations it has been seen in the rivulets of Hudson Bay, as much as ninety miles inland from the sea; here it seeks out its appropriate fare of spawn, shell-fish and the larvæ of aquatic or fluviatile insects. On the low bushy and shady banks of these streams it constructs its nest, which contains from twelve to fourteen pure white eggs. On the margins of freshwater ponds in Labrador Mr. Audubon also observed this species, and he remarks, that instead of rearing their young in the same situations chosen for breeding, as with the relvet and surf duck, it conducts its brood to the sea as soon as they are hatched. Its flight is high and swift; and it swims and dives with the utmost dexterity. So great is its confidence in the security of its most natural element, that on the report of a gun over the water, it instantly quits its flight and dives at once with the celerity of thought. It is said to be clamorous, and that its roice is a sort of whistle; the anatomy of the trachea is however, unknown, and it is not said whether this sibilation be really produced from the throat or the wings, as is the latter case in the common clangula or golden eye. Driven from their solitary resorts in the interior by the invasion of frost, they are now seen out at sea engaged in obtaining a different mode of subsistence. Amidst these icy barriers they still continue to endure the rigors of winter, continually receding farther out to sea, or making limited and almost accidental visits to milder regions. When discovered, they display the utmost vigilance, and instantly take to wing. It is considered to be a game superior in flavor to the common wild duck. From the singular and beantiful 
crescent-shaped lines and marks which ornament its neck and breast it has probably come by the dignified appellation of lord, among the fishers of Newfoundland. It is here too rare to have acquired any particular name.*

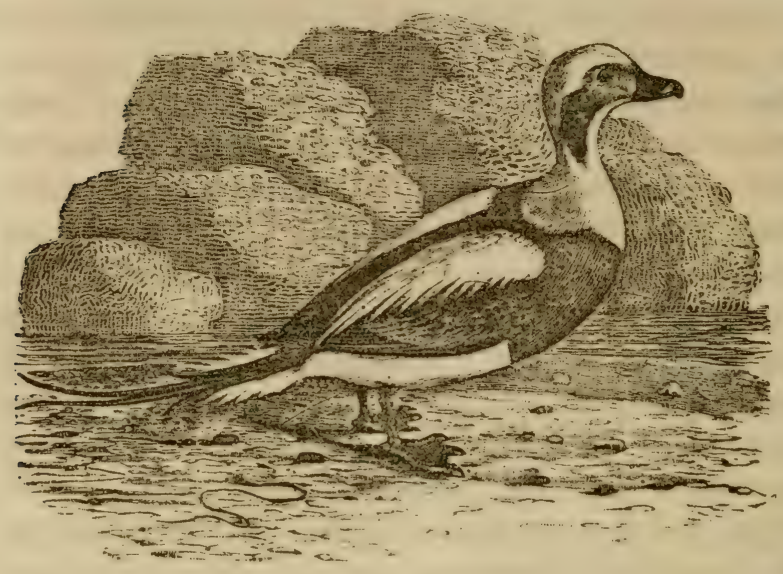

THE LONG-TAILED DUCK.

The Long-Tailed Duck (Fuligula Glacialis) is often seen among the water birds on the Pacific shores. This elegant and noisy duck, known so generally in the Southern States by the nickname of 'SouthSoutherly,' from its note, and, in most other parts by the appellation of 'Old Squaws' or 'Old Wives,' is an Arctic inhabitant of both continents, and abounds in the glacial seas of America, where it is seen commonly associated with the eider, surf, black and other ducks of congenial habits, who invariably prefer the 
frail but, to them, productive dominion of the sea to the land or its more peaceful waters. So strong is the predilection of this species for its frigid natal climes and their icy barriers, ${ }^{*}$ that it is secn to linger in the north as long as the existence of any open water can be ascertained; when the critical moment of departure, at length approaches, common wants and general feeling begin so far to prevail as to unite the scattered families into numerous flocks. They now proceed towards the south, and making a halt on the shores and inland lakes round Hudson Bay, remain until again reluctantly driven towards milder climes. They are the last birds of passage that take leave of the fur countrics. Familiar with cold, and only driven to migrate for food, in the latter end of August, when already a thin crust of ice is seen forming in the night orer the still surface of the Arctic Sea, the female Harelda is olserved ingeniously breaking a way with her wings for the egress of her young brood.

According to the state of the weather we consequently observe the variable arrival of these birds. In October they generally pay us a visit, the old already clad in the more clazzling garb of winter. The young sometimes seek out the shelter of the freshwater ponds, but the old kecp out at sea. No place in the Union so abounds with these gabblers as the Bay of Chesapealie. They are lively, restless and gregarious in all their morements, and fy, dive, and swim with univalled dexterity; and subsist chiefly upon small shell-fish, and marine plants, particularly the zostera or grass-wrack. Late in the evening, or

* Nuttall. 
early in the morning, towards spring more particularly, vast flocks are seen in the bays and sheltered inlets, and in calm and foggy weather we hear the loud and blended nasal call reiterated for hours from the motley multitude. There is something in the sound like the honk of the goose, and as far as words can express a subject so uncouth, it resembles the guttural syllables 'ogh ough egh, and then 'ogh ogh ogh ough $e g h$, given in a ludicrous drawling tone; but still with all the accompaniments of scene and season, this humble harbinger of spring, obeying the feelings of nature, and pouring forth his final ditty before his departure to the distant north, conspire with the novelty of the call, to please rather than disgust those happy few who may be willing "to find good in every thing." This peculiar cry, is well known to the aboriginal sons of the forest, and among the Crees the species is called "Hah-ha-way," so much like the syllables I have given above, that many might imagine my additions no more than a rersion of the same.

The Velvet Duck (Fuligula fusca) is another beautiful species of this genus.

The Velvet Duck is common to the northern regions of both continents, where it retires late in the spring to pass the period of reproduction. Like the preceding, they live principally upon the sea and its productions, diving often in broken water for shell-fish and other marine bodies. They breed along the Arctic coast and around Hudson Bay and Labrador, retiring inland for the purpose; nesting contiguous to small fresh-water pools in the shelter of juniper or pine bushes, laying from eight to ten white eggs, 


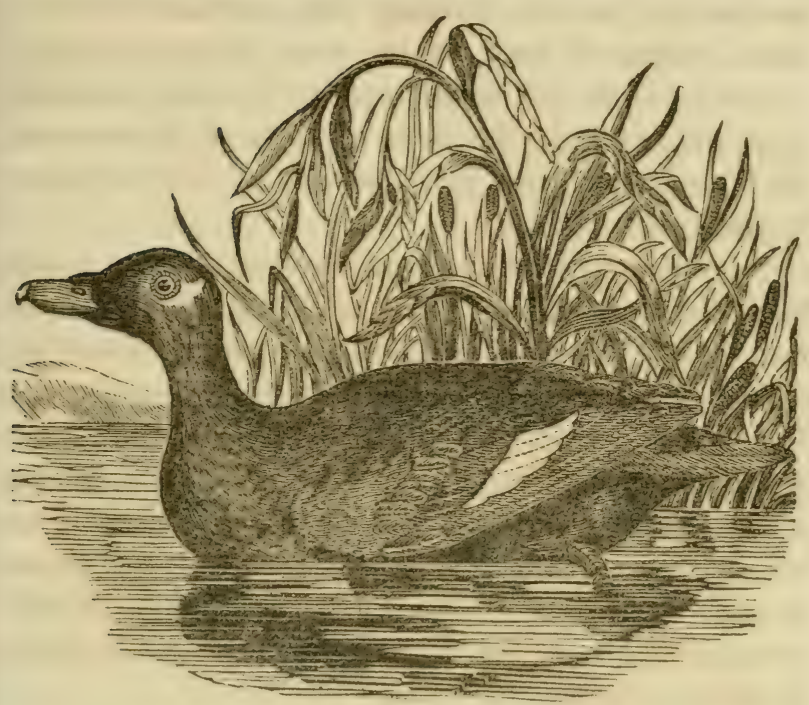

VELVET DUCK.

which the female closely covers with her elastic feather. The young are attended by the female only, who remains with her brood in these seclusions until they are nearly ready to fly. She also makes a show of defending them, and the young themselves often by their great alertness in diving escape the attacks of their enemies. They are abundant in the Orkneys and Hebrides, as well as in Norway, Sweden and Lapland; and are common in some parts of Siberia and Kamtschatka. Near Kengis, on the banks of the Tornea in Lapland, a little beyond the 67th parallel, Skioldebrand remarked them nesting in trees, particularly pines, accompanied by the golden eye (Fuligula clanglua). The inhabitants, he also adds, knowing the 26 
trouble they have in forming their nests, attach hollowed pieces of wood to the trees for their convenience; and in recompense receive a quantity of their eggs, which supply the place of those of the common fowl, no longer found to endure the severity of these hyperboreal climates.

On the commencement of incubation, the males leave the land and again assemble together in flocks out at sea. In the moulting season, which soon after takes place among these seceding birds, the natives at Ochotska to the number of fifty or more, in the same manner as the Indians of the Bay of Fundy, taking advantage of the flood tide, drive the whole flock before them up the river, in canoes, and as soon as the water ebbs, they despatch them with clubs in such numbers that each individual often comes in for twenty or thirty to his share.

The Velvet Duck is said to return late to its breeding quarters in Sweden, the eggs being sometimes found fresh as late as the beginning of July. In April they are seen, in cloudy weather more particularly, proceeding steadily on the wing in large flocks towards their northern destination. At these times they fly low in an irregular angular phalanx, making a straight course just outside of the land, and are perfectly silent and intent on their voyage. In the spring of 1831, I saw them thus migrating by thousands, though not more thin twelve to twenty associate in any one flock. They proceed in all probability to the very extremity of the Union, in the course of the winter, are very abundant in the Bay of Chesapeake, being usually accompanied by the scoters, and are taken sometimes in the same nets with them. With the other dark 
species of this subgenus they are here known by the appellation of Coots, and these are distinguished by the name of the White-Winged kind. Whether from their nocturnal habits or what other cause, I cannot pretend to say, when they have been seen in Fresh Pond, which they sometimes visit, at least the young, their heads have been observed nodding, as though they were oppressed by sleep; and we sometimes here have a saying of being as sleepy as a Coot. The flesh of the old bird is strong, dark, and sedgy, yet they are much sought after in this quarter, and often exposed for sale in the market, particularly the young birds whose flavor is more tolerable. They arrive in New England from the north about the close of September, and according to Richardson, spend some time on the coasts of Hudson Bay and the lakes of the interior previous to their departure for the south.*

The Cormorant (Phalacrocorax carbo). This uncouth and gluttonous bird is plentiful on the rocky shores of Great Britain, Holland, France, and Germany. On the shores of the Caspian they are sometimes seen in vast flocks, and are frequent on Lake Baikal. They inhabit China, the coast of the Cape of Good Hope, and are common in the Phillippine Islands, New Holland, New Zealand, and other neighboring regions. At Nootka Sound, and in Kamtschatka they have been observed by various navigators; and are found in North America, from Hudson Bay and Labrador, to the coasts of Carolina and Georgia. 'They are not howerer common in the central parts of the United States, though they penetrate into the interior as far as the Missouri River. They breed, and are 


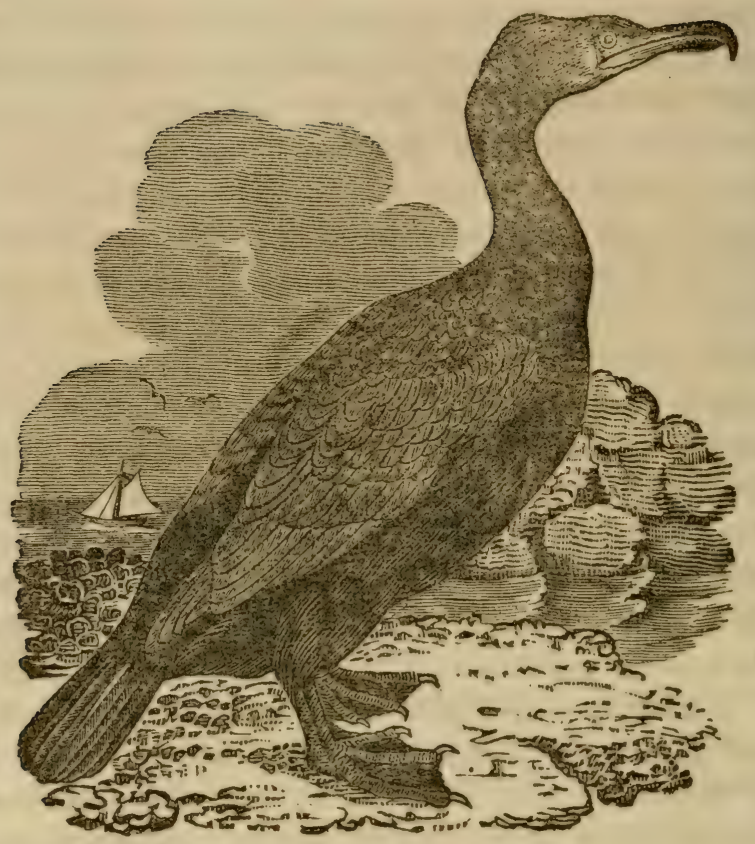

CORMORANT.

seen in the vicinity of Boston on bare and rocky islands, nearly throughout the year, and in all places appear shy, retiring and sedentary, enduring the most severe weather with impunity, and only removing seawards or south in the depth of winter for the purpose of acquiring food. Mr. Aububon found them breeding on the ledges of almost inaccessible rocks at Grand Manan Isle, in the Bay of Fundy. Their eggs are three to five, white, roughened with a calcareous incrustation, and small for the size of the bird. They appear very wary and shy, and feed their young with 
great assiduity, whose roice at this time resembles the hissing of snakes.

The Cormorant is a very dexterous and voracious fisher, committing great havoc when it visits pools and lakes; but it almost constantly resides on the sea shores, and is seldom seen inland. Swimming beneath the water with the velocity of a dart in the air, and remaining a long time submerged, its prey scarcely ever escapes, and it almost always rises with a fish in its bill, to swallow which it employs the expedient of tossing it into the air, and dexterously catches the head in its descent, so that the fins lie flat, and thus favor the passage down the throat; the small pouch at the same time stretches so as to admit the whole body of the fish, which is often very large in proportion to the neck, and it there remains undergoing a preparatory digestion previous to its passage into the lower part of the stomach.

In some countries, as in China, and formerly in England, the dexterity of the Cormorant in fishing was turned to profit; for, by buckling a ring about the lower part of the neck, to prevent deglutition, and accustoming it to return with its acquisitions in the bill to its master, it was made a useful and domestic fisher. On the rivers of China, Cormorants, thus fixed, are perched on the prows of boats, and at a signal made by striking the water with an oar, they instantly plunge, and soon emerge with a fish, which is taken from them; and this toil continued till its master is satisfied, he looses the collar, and finishes the task by allowing it to fish for itself. But it is only hunger which gives activity to the Cormorant; when glutted with its meal, which is soon acquired, it relaxes into its native indolence, and dozes away the 


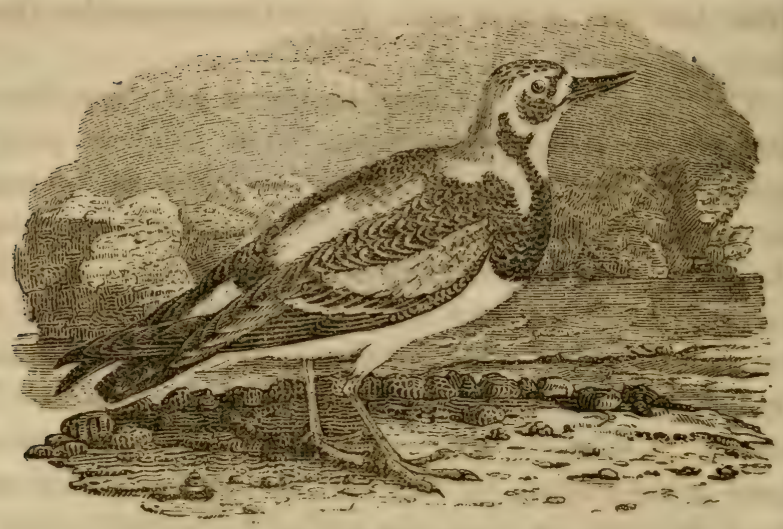

SEA DOTTEREL.

greatest part of its time in gluttonous inebriety, perched in solitude on naked and insulated or inaccessible rocks to which it prudently retires for greater safety from the intrusion of enemies.

The Turnstone, or Sea Dotterel, (Strepsilus interpres) is also a visiter in California.

This singular marine bird is not only common to the whole northern hemisphere, but extends its colonies even to Senegal and the Cape of Good Hope, in the southern half of the globe. Their favorite breeding resorts are, however, confined to the inclement regions of the north, to which they are in no haste to return, but linger along the coast in the temperate climates for several months, before they attain to the remote and desolate shores of their nativity. Their southern progress in America, is in all probability continued as far as the tropies, since their race even extends itself into the other hemisphere. Buffon, in fact, figures a specimen of the young bird from Cayenne. In New Jersey, according to Wilson, they 
arrive in the month of April, and there linger until June, very soon after which they are seen at their breeding quarters, on the shores of Hudson Bay, and along the desolate strand of the Arctic Sea, where they hare been met with by the northern navigators, as far as the 75th parallel. They already begin to depart from these remote boreal regions in August, in which month, and even towards the close of July, I have seen young birds for sale in the market of Boston. They visit the shores of Great Britain also about the same time, arriving thence probably from the Aretie shores of Siberia. Fire or six weeks later, they are observed to visit the borders of the Delaware, and proceed onward to the south as the weather increases in coldness. The most southern summer residence of this species known, if Mr. Fleming be correct, is the Scottish isle of Zetland. They are also said to inhalbit the isles of the Baltic during summer. In a mere depression of the sand or gravel, along the sea coast, it is said to drop its eggs, which are four in number, and according to Mr. Hutchins, are of an olive green, spotted with blackish brown.

It is naturally of a wild and solitary disposition, coursing along the shore by pairs, or in small families which have been bred together. In the months of May and June, in New Jersey, they almost wholly feed upon the spawn of the king-crab, or horse-foot, (Monoculus polyphemus, Lrx.) which affords them and other animals an abundant and almost inexhaustible supply.

We could easily extend this list of the quadrupeds and birds of California much further; but we have already shown that the country abounds in game as 
well as in the various other objects of interest which form the study of the zoologist.

All writers agree that the waters of California abound in fish in a most extraordinary degree. Numberless varieties of sea fish literally swarm off the coast, and the rivers abound in valuable kinds suitable for the table. Shell fish are also abundant; oysters, the pearl shell, already referred to, clams and several species of the haliotis are found. Salmon which are

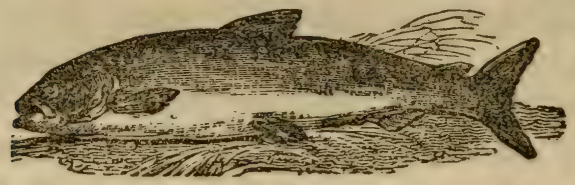

SALMON.

known to be so abundant in the Columbia River, are not less so in the San Joaquin and Sacramento. Two or three thousand, according to Farnham, are sometimes taken in a day. The Indians take them in a basket of wicker work like a lobster basket, as they pass up the rivers in the spring. They are also very skilful in spearing them. The fish are preserved by drying and salting.

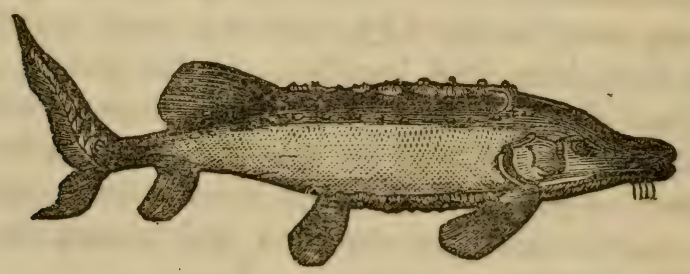

STURGEON.

The Sturgeon (Accipenser transmontanus), is found in the large rivers eight or ten feet in length, and weighing five hundred pounds. 
In the Bay of Monterey there are great numbers of the Mackerel and a fish similar to the Sardine. Porpoises are seen playing and spouting in the bays, and the whale is found off the coast.

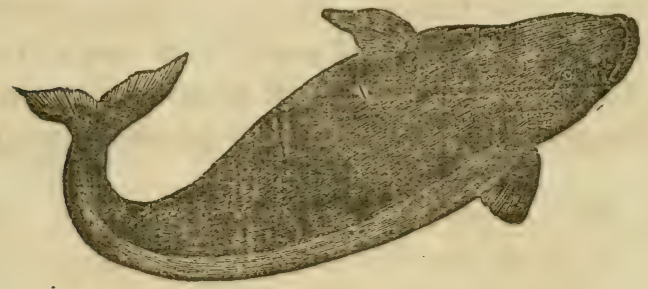

PORPOISE.

Mr. Farnlam enumerates among the fishes, the halibut, skate, turbot, and bonito. But these of course form but a very small part of that immense variety which are found on the coast where the fish of the tropical regions are mingled with those which people the waters of the north.

In the plants and trees of California there is a visible field for the future explorations of the botanist. In the vegetable as in the animal kingdom, we find the products of various latitudes from the tropics to the arctic regions all mingled together. Several varieties of the pine are found, the most remarkable of which is the Pinus Douglasii, first described by Douglas. In the mountains about the Bay of San Francisco, the Colorado River, and other parts of Upper California specimens of this tree are found two hundred and forty feet high, the bases of whose trunks are nearly sixty feet in circumference. The trunk, says Farnham, is quite destitute of branches until above more than half the altitude, when they grow outward and upward 
in such a manner as to give the top the form of an inverted pyramid. From the ends of the branches hang the cones or seed-vessels, from twelve to fifteen inches in length, and egg-shaped. The seeds are as large as a good-sized bean, and furnish a common article of food to the Indians, who collect large quantities of them in the autumn, and pound them into a kind of cake, which is baked on heated stones. The wood is very fine-grained, and contains a great quantity of resin.

The Pinus Sabinii, $P$. Lambertiana, $P$. noblis, and $P$. resinosa, are also fine species, though less in size than their gigantic relative. The former is, however, a large tree, being often found one hundred and ten feet high, and from ten to twelve in diameter. Among the elevated plains of Upper California it grows quite plentifully, as also on the low hills, near the coast, where it attains a larger size. The natives frequently build their fires against these trees to save the trouble of collecting fuel. By this means, also, a sweet gum is made to exude from the trunk, which serves them for sugar.

Mr. Farnham also mentions among the trees of California, the White Oak, Live Oak, Maple, Ash, Beech, and Chestnut.

The flowering shrubs and plants of California are very numerous. Mr. Farnham says:

It is impossible to give a full description of the flowering shrubs and plants of Upper California, so great is their variety and beauty. We have only space to notice a few of the most conspicuous. A species of Raspberry, Ribes speciosum, is one of the most elegant flowering shrubs of the country. It is exceedingly abundant in some localities, and, with its 
long crimson stamens and its deep green leares, presents an appearance truly lovely. The flowers bloom early in spring. The fruit I have not seen. In many places are found several species of Mimulus, one of which is from three to four feet in height, and is a very showy plant. This country also has numerous species of Phlox and Heuchera, and innumerable quantities of Epilobium, Enothera or Primrose, Pentstemon, Xapaver or Poppy, Delphinium, and Salvia. A species of lily also grows here, the roots of which are eaten by the natives. The Scilla esculenta grows along the whole coast of Upper California. This is called by the natives "Quamash," and the root forms a rery common article of food. To prepare this for eating, a hole is made in the ground, and a number of stones placed in it, on which a fire is kindled, and kept burning until they are made hot, when the fire is extinguished, and the roots wrapped in straw, leaves, and moss, and placed upon them. They are well roasted in a few hours; and are then taken off and hung up to dry. This root is also sometimes pounded and made into cakes, which are preserved for future use. The taste is sweet, and rather agrceable; but if eaten too freely, they are apt to produce diarrhoea. This plant is most abundant on the banks of rivers and on lowlands by the margins of forests; in which localities are also found several species of Pyrola, Caprifolium, and Lupinus, which sometimes cover an immense extent of land. The Arbutus is also abundant in similar situations. The large species, $A$. procera, is a fine shrub, frequently attaining a growth which entitles it to be called a tree. The A. uva ursi is found in almost every part of the colder sections of the country, and its berries are fre- 
quently eaten by the natives, and even by travellers. A very useful plant to the natives is the Helonias tenax, the fibres of which are stronger than any hemp. Cords made of this are used by the Indians for the purpose of snaring deer and other animals; and one the thickness of the little finger is so strong as not to be broken by the largest elk.

The Gooseberry grows in Upper California, and bears plentifully. The sand-hills and moors are covered with a great variety of Syngenesious plants, and on the more fertile and humid soil grows a gaudyflowered Currant-bush and a pretty species of Honeysuckle. Perhaps the most remarkable shrub here is the Yedra, a poisonous plant, which, however, affects some particular constitutions only. By contact with the skin, it produces tumors and violent inflammation. It is a slender shrub, preferring cool and shady places, and bearing a trefoil crenated leaf. Two roots-the plants of which I have not seen-are used by the natives for soap; these are called Amole and Samate. On the rocky coast south of Monterey are immense collections of sea-weed-Fucus pyrifornis-which are said to have gathered there in such abundance, as to have saved several ressels from splitting on the rocks, when driven on them by the tempest.

A resident in California writing to a member of Congress, thus speaks of the vegetable productions and appearance of the country.

I know you will ask me for reasons for this. Apart from the gold, and the people who have, are coming, and will come, to possess it, I can give you one, and you not having seen for yourself cannot appreciate the truth of my remarks. All I can do is to ask you to rely upon my assertion, which in its terms falls 
short of what the reality would appear to you were you here. Our country is a continued succession of mighty mountain ranges, perpetually snow-capped, and peopled with the grisly bear, between which high and lofty mountains are deep, beautiful, fertile and luxuriant valleys, which have no superiors and few parallels in America, either for richness of soil or beauty of landscape. Wheat, barley, oats, \&c., grow here finer than in any State in the Union. The grains are generally produced without irrigation; but with irrigation, you can have a succession of two or three crops a year. Our coldest weather does not exceed that of New Orleans, never seeing more than a slight white frost, while for six months of the year you can see from where you stand, at any time, the terrible snow storm raging on the mountain tops, while the landscape at your feet is covered with Flora's most lorely variety of flowers. Our valleys are mostly prairies, with timber enough for fires and fences, but none for lumber. The latter is to be had in the mountains. The gigantic trees down in Maine are mere bushes to our pines, redwood, hemlock, spruce, and firs, from three hundred to five hundred feet in height, and twenty, nay, up to thirty feet in diameter -as straight and tapering from the root to the top (the latter only as big as your finger) as if they had been turned in a lathe by a skilful mechanic. Such forests, both as to timber and extent!-You cannot realize the idea I wish to convey. I once helped to fell some of these gigantic trees, with my own hands, to make fire to keep from freezing, while in a terrible storm of fourteen days and nights, exposed to all its furies, without any covering but the skies. When we at last reached the Sacramento valley, the contrast 
was indescribable-it was one extended flower-bed and grass-plat!

Of the mineral riches of California we have already given so full an account in the previous chapters of this work, that it is unnecessary to advert to it in this connexion. In justice to Mr. Farnham, however, we cannot omit to quote a passage from his excellent work "Life, Adventures, and Travels in California," published before the discovery of the gold mines, in which the future destiny of California is distinctly foretold.

"No doubt is entertained by those best acquainted with the Californias, that they will become, when science shall be applied in the development in their wealth, one of the richest mineral provinces in America. This belief is much strengthened by the fact, that the Indians, whenever they choose, can bring into the settlements large quantities of these ores, which they either find on the surface, or pry from the crevices of the rocks with sharpened sticks, bones, or hunting knives. They cannot be induced to show the whites where they obtain these, on account of an old traditional superstition, that if they should do so, they would immediately die." 


\section{APPENDIX.}

\section{Appendix A. \\ CONSTITUTION OF CAIIFORNIA.}

PRDCLAMATION TO TIIE PEOPLE OF CALIFORNIA.

THe delegates of the people assembled in Convention, have formed a constitution, which is now presented for your ratification. The time and manner of roting on this constitution, and of holding the first general election, are clearly set forth in the schedule. The whole subject is, therefore, left for your unbiassed and deliberate consideration.

The Prefect (or person exercising the functions of that office) of each district, will designate the places for opening the polls, and give due notice of the election, in accordance with the prorisions of the constitution and schedule.

The people are now called upon to form a government for themselves, and to designate such officers as they desire, to make and execute the laws. That their choice may be wisely made, and that the govern- 
ment so organized may secure the permanent welfare and happiness of the people of the new State, is the sincere and earnest wish of the present Executive, who, if the constitution be ratified, will, with pleasure, surrender his powers to whomsoever the people may designate as his successor.

Given at Monterey, California, this 12th day of October, A. D., 1849.

(Signed)

B. RrLey;

Brevet Brig. General, U. S. A., and Governor of California.

(Official) H. W. HALLECK,

Brevet Captain and Secretary of State.

WE THE PEOPLE OF CALIFORNIA, GRATEFUL TO AIMIGHTY GOD FOR OUR FREEDOM, IN ORDER TO SECURE ITS BLESSINGS, DO ESTABLISH THIS CONSTITUTION :-

\section{A RTICLE I.}

DECLARATION OF RIGHTS.

SEc. 1. All men are by nature free and independent, and have certain inalienable rights, among which are those of enjoying and defending life and liberty, acquiring, possessing, and protecting property, and pursuing and obtaining safety and happiness.

SEC. 2. All political power is inherent in the people. Government is instituted for the protection, security, and benefit of the people; and they have the right to alter or reform the same, whenever the public good may require it. 
SFC. 3. The riglit of trial by jury shall be secured to all, and renain inviolate for ever; but a jury trial may be waired by the partie:s, in all civil cases, in the manner to be prescribed by law.

SEc. 4. The fice exercise and enjoyment of religious profession and worship, without discrimination or preference, shall for ever be allowed in this State; and no person shall be rendered incompetent to be a witness on account of his opinions on matters of religious belief; but the liberty of conscience, hereby secured, shall not be so construed as to excuse acts of licentiousness, or justify practices inconsistent with the peace or safety of this State.

SEC. 5. The privilege of the writ of habeas corpus shall not be suspended, unless when, in cases of rebellion or invasion, the public safety may require its suspension.

SEC. 6. Excessire bail shall not be required, nor excessive fines imposed, nor shall cruel or unusual punishments be inflicted, nor shall witnesses be unreasonably detained.

SEc. 7. All persons shall be bailable, by sufficient sureties: unless for capital offences, when the proof is evident or the presumption great.

Srac. 8. No person shall be held to answer for a capital or otherwise infamous crime (except in cases of impeachment, and in cases of militia when in actual service, and the land and naval forces in time of war, or which this State may keep with the consent of Congress in time of peace, and in cases of petit lareeny under the regulation of the Legislature,) unless on presentment or indictment of a grand jury; and in any trial in any court whaterer, the party accused shall be allowed to appear and defend in person 
and with counsel, as in civil actions. No person shall be subject to be twice put in jeopardy for the same offence; nor shall he be compelled, in any criminal case, to be a witness against himself, nor be deprived of life, liberty, or property, without due process of law; nor shall private property be taken for public use without just compensation.

SEC. 9. Ercry citizen may freely speak, write, and publish his sentiments on all subjects, being responsible for the abuse of that right; and no law shall be passed to restrain or abridge the liberty of speech or of the press. In all criminal prosecutions on indictments for libels, the truth may be given in evidence to the jury; and if it shall appear to the jury that the matter charged as libellous is true, and was published with good motives and for justifiable ends, the party shall be acquitted: and the jury shall have the right to determine the law and the fact.

SEC. 10. The people shall have the right freely to assemble together, to consult for the common good, to instruct their representatives, and to petition the legislature for rediess of grievances.

SEc. 11. All laws of a general nature shall have a uniform operation.

SEC. 12. The military shall be subordinate to the civil power. No standing army shall be kept up by this State in time of peace; and in time of war no appropriation for a standing army shall be for a longer time than two years.

SEC. 13. No soldier shall, in time of peace, be quartered in any house, without the consent of the owner; nor in time of war, except in the manner to be prescribed by law. 
SEc. 14. Representation shall be apportioned according to population.

SEC. 15. No person shall be imprisoned for debt in any civil action on mesne or final process, unless in cases of fraud; and no person shall be imprisoned for a milita fine in time of peace.

SEc. 16. No bill of attainder, ex post facto law, or law impairing the obligation of contracts, shall ever be passed.

SEc. 17. Foreigners who are, or who may hereafter become, bona fide residents of this State, shall enjoy the same rights in respect to the possession, enjoyment, and inheritance of property, as native born citizens.

SEc. 18. Neither slavery, nor involuntary servitude, unless for the punishment of crimes, shall ever be tolerated in this State.

SEC. 19. The right of the people to be secure in their persons, houses, papers and effects, against unreasonable seizures and searches, shall not be violated; and no warrant shall issue but on probable cause, supported by oath or affirmation, particularly describing the place to be searched, and the persons and things to be seized.

SEc. 20. Treason against the State shall consist only in levying war against it, adhering to its enemies, or giving them aid and comfort. No person shall be convicted of treason, unless on the evidence of two witnesses to the same overt act, or confession in open court.

SEC. 21. This enumeration of rights shall not be construed to impair or deny others retained by the people. 


\section{ARTICLE II.}

RIGHT OF SUFFAGE.

SEC. 1. Every white male citizen of the United States, and every white male citizen of Mexico, who shall have elected to become a citizen of the United States, under the treaty of peace exchanged and ratified at Queretaro, on the 30th day of May, 1848, of the age of twenty-one years, who shall have been a resident of the State six months next preceding the election, and the county or district in which he claims his vote thirty days, shall be entitled to vote at all elections which are now or hereafter may be authorized by law: Provided, that nothing herein contained shall be construed to prevent the Legislature, by a two-thirds concurrent vote, from admitting to the right of suffrage, Indians or the descendants of Indians, in such special cases as such a proportion of the legislative body may deem just and proper.

SEc. 2. Electors shall, on all cases except treason, felony, or breach of the peace, be privileged from arrest on the days of the election, during their attendance at such election, going to and returning therefrom.

SEc. 3. No elector shall be obliged to perform militia duty on the day of election, except in time of war or public danger.

SEC. 4. For the purpose of voting, no person shall be deemed to have gained or lost a residence by reason of his presence or absence while employed in the service of the United States; nor while engaged in the navigation of the waters of this State, or of the United States, or of the high seas ; nor while a student of any seminary of learning; nor while kept at any 
almshouse, or other asylum, at public expense; nor while confined in any public prison.

Sec. 5. No idiot or insane person, or person convicted of any infamous crime, shall be entitled to the privileges of an elector.

SEC. 6. All elections by the people shall be by ballot.

\section{ARTICLE III.}

DISTRIBUTION OF POWERS.

The powers of the government of the State of California shall be divided into three separate departments : the Legislature, the Executive, and Judicial; and no person charged with the exercise of powers properly belonging to one of these departments, shall exercise any functions appertaining to either of the others; except in the cases hereinafter expressly directed or permitted.

\section{ARTICLE IV.}

LEGISLATIVE DEPARTMET.

SEC. 1. The legislative power of this State shall be rested in a Senate and Assembly, which shall be designated the Legislature of the State of California, and the enacting clause of every law shall be as follows: "The people of the State of California, representer in Senate and Assembly, do enact as follows."

SEc. 2. The sessions of the Legislature shall be annual, and shall commence on the first Monday of January, next ensuing the election of its members; unless the Governor of the State shall, in the interim, convene the Legislature by proclamation.

SEC. 3. The members of the Assembly shall be 
chosen annually, by the qualified electors of their respective districts, on the Tuesday next after the first Monday in November, unless otherwise ordered by the Legislature, and their term of office shall be one year.

SEC.4. Senators and Members of Assembly shall be duly qualified electors in the respective counties and districts which they represent.

SEC. 5. Senators shall be chosen for the term of two years, at the same time and places as Members of Assembly; and no person shall be a Member of the Senate or Assembly, who has not been a citizen and inhabitant of the State one year, and of the country or district for which he shall be chosen six months next before his clection.

SEC. 6. The number of Senators shall not be less than one third, nor more than one half, of that of the Members of Assembly; and at the first session of the Legislature after this Constitution takes effect, the Senators shall be divided by lot as equally as may be, into two classes; the seats of the Senators of the first class shall be vacated at the expiration of the first year, so that one half shall be chosen annually.

Sec. 7. When the number of Senators is increased, they shall be apportioned by lot, so as to keep the two classes as nearly equal in number as possible.

Sec. 8. Each house shall choose its own officers, and judge of the qualifications, elections, and returns of its own members.

SEC. 9. A majority of each house shall constitute a quorum to do business; but a smaller number may adjourn from day to day, and may compel the attendance of absent members, in such manner, and under such peualties as each house may provide. 
SEC. 10. Each house shall determire the rules of its own proceedings, and may with the concurrence of two-thirds of all the members elected, expel a member.

SEc. 11. Each house shall keep a journal of its own proceedings, and publish the same; and the yeas and nays of the members of either house, on any question, shall, at the desire of any three members present, be entered on the journal.

SEC. 12. Members of the Legislature shall, in all cases except treason, felony, and breach of the peace, be privileged from arrest, and they shall not be subject to any civil process during the session of the Legislature, nor for fifteen days next before the commencement and after the termination of each session.

SEc. 13. When racancies occur in either house, the Governor, or the person exercising the functions of the Governor, shall issue writs of election to fill such vacancies.

SEc. 14. The doors of each house shall be open, except on such occasions as in the opinion of the house may require secrecy.

Sec. 15. Neither house shall, without the consent of the other, adjourn for more than three days, nor to any other place than that in which they may be sitting.

SEc. 16. Any bill may originate in either house of the Legislature, and all bills passed by one house may be amended in the other.

SEC. 17. Every bill which may have passed the Legislature, shall, before it becomes a law, be presented to the Gorernor. If he approve it, he shall sign it; but if not, he shall return it, with his objections, to the house in which it originated, which shall enter the same upon the journal, and proceed to re- 
consider it. If, after such reconsideration, it again pass both houses, by yeas and nays, by a majority of two-thirds of the members of each house present, it shall become a law, notwithstanding the Governor's objections. If any bill shall not be returned within ten days after it shall have been presented to lim, (Sunday excepted,) the same shall be a law, in like manner as if he had signed it, unless the Legislature, by adjournment, prevent such return.

SEc. 18. The Assembly shall have the sole power of impeachment; and all impeachments shall be tried by the Senate. When sitting for that purpose, the Senators shall be upon oath or affirmation; and no person shall be convicted without the concurrence of two-thirds of the members present.

SEc. 19. The Governor, Lieutenant-Governor, Secretary of State, Comptroller, Treasurer, AttorncyGeneral, Surveyor-General, Justices of the Supreme Court, and Judges of the District Courts, shall be liable to impeachment for any misdemeanor in office; but judgment in such cases shall extend only to removal from office, and disqualification to hold any office of honor, trust or profit, under the State; but the party convicted, or acquitted, shall nevertleeless be liable to indictment, trial and punishment, according to law. All other civil officers shall be tried for misdemeanors in office, in such manner as the Legislature may provide.

SEC. 20. No Senator or member of Assembly shall, during the term for which he shall have been elected, be appointed to any civil office of profit, under this State, which shall have been created, or the emoluments of which shall have been increased, during such 
term, except such office as may be filled by elections by the people.

SEc. 21. No person holding any lucrative office under the United States, or any other power, shall be eligible to any civil office of profit, under this State; provided, that officers in the militia, to which there is attached no annual salary, or local officers and postmasters whose compensation does not exceed five hundred dollars per annum, shall not be deemed lucrative.

SEc. 22. No person who shall be convicted of the embezzlement or defalcation of the public funds of this State, shall ever be eligible to any office of honor, trust, or profit, under the State; and the Legislature shall, as soon as practicable, pass a law providing for the punishment of such embezzlement, or defalcation, as a felony.

Sec. 23. No money shall be drawn from the Treasury but in consequence of appropriations made by low. An accurate statement of the receipts and expenditures of the public moneys shall be attached to, and published with, the laws, at every regular session of the Legislature.

SEc. 24. The mombers of the Legislature shall receire for their services, a compensation to be fixed by law, and paid out of the public treasury; but no increase of the compensation shall take effect during the term for which the members of either house shail have been elected.

SEc. 25. Every law enacted by the Legislature, shall embrace but one object, and that shall be expressed in the title; and no law shall be revised, or amended, by reference to its title; but in such case, 
the act revised, or section amended, shall be reenacted and published at length.

SEC. 26. No divorce shall be granted by the Legislature.

SEc. 27. No lottery shall be authorized by this State, nor shall the sale of lottery tickets be allowed.

SEc. 28. The enumeration of the inhabitants of this State shall be taken, under the direction of the Legislature, in the year one thousand eight hundred and fifty-two, and one thousand eight hundred and fiftyfive, and at the end of every ten years thereafter; and these enumerations, together with the census that may be taken, under the direction of the Congress of the United States, in the year one thousand eight hundred and fifty, and every subsequent ten years, shall serve as the basis of representation in both houses of the Legislature.

SEc. 29. The number of Senators and Members of Assembly, shall, at the first session of the Legislature, holden after the enumeration herein provided for are made, be fixed by the Legislature, and apportioned among the several counties and districts to be established by law, according to the number of white inhabitants. The number of Members of Assembly shall not be less than twenty-four, nor more than thirty-six, until the number of inhabitants within this State shall amount to one hundred thousand: and after that period, at such ratio that the whole number of Members of Assembly shall never be less than thirty, nor more than eighty.

SEc. 30. When a congressional, senatorial, or assembly district, shall be composed of two or more counties, it shall not be separated by any county belonging to another district; and no county shall be 
divided, in forming a congressional, senatorial, or assembly district.

SEc. 31. Corporations may be formed under general laws, but shall not be created by special act, except for municipal purposes. All general lars and special acts passed pursuant to this section may be altered from time to time, or repealed.

SEc. 32. Ducs from corporations shall be secured by such individual liability of the corporators, and other means, as may be prescribed by law.

SEc. 33. The term corporations, as used in this article, shall be construed to include all associations and joint-stock companies, having any of the powers or privileges of corporations not possessed by individuals or partnerships. And all corporations shall have the right to sue, and shall be sulject to be sued, in all courts, in like cases as natural persons.

SEc. 34. The Legislature shall have no power to to pass any act granting any charter for banking purposes; but associations may be formed under general laws, for the deposit of gold and silver; but no such association shall make, issue, or put in circulation, any bill, check, tickets, certificate, promissory note, or other paper, or the paper of any bank, to circulate as money.

SEc. 35. The Legislature of this State shall prohibit, by law, any person or persons, association, company, or corporation, from exercising the privileges of banking, or creating paper to circulate as money.

SEc. 36. Each stockholder of a corporation, or joint-stock association, shall be individnally and personally liable for his proportion of all its debts and liabilities.

SEC. 37. It shall be the duty of the Legislature to 
provide for the organization of cities and incorporated villages, and to restrict their power of taxation, assessment, borrowing money, contracting debts, and loaning their credit, so as to prevent abuses in assessments, and in contracting debts, by such municibal corporations.

SEC. 38. In all elections by the Legislature, the members thereof shall rote viva voce, and the rotes shall be entered on the journal.

\section{ARTICLE V.}

EXECUTIVE DEPARTMET.

SEc. 1. The supreme executive power of this State shall be rested in a chief magistrate, who shall be styled the Governor of the State of California.

SEc. 2. The Gorernor shall be elected by the qualified electors, at the time and places of roting for Members of Asscmbly, and shall hold his office two years from the time of his installation, and until his successor shall be qualified.

SEC. 3. No person shall be eligible to the office of Governor (except at the first election) who has not been a citizen of the United States and a resident of this State two years next preceding the election, and attained the age of twenty-five years at the time of said election.

SEC. 4. The returns of every election for Governor shall be sealed up and transmitted to the seat of government, directed to the Speaker of the Assembly, who shall, during the first week of the session, open and publish them in presence of both houses of the Legislature. The person having the highest number of rotes shall be Governor; but in case any two or 
more hare an equal and the highest number of rotes, the Legislature shall by joint-rote of both houses, choose one of said persons, so having an equal and the highest number of rotes, for Gorernor.

SEc. 5. The Governor shall be commander-in-chief of the militia, the army, and navy of this State.

SEc. 6. He shall transact all executive business with the officers of government, civil and military, and may require information in writing from the officers of the executive department, upon any subject relating to the duties of the respective offices.

SEc. 7. He shall see that the laws are faithfully executed.

SEC. 8. When any office shall, from any cause, become vacant, and no mode is provided by the constitution and laws for filling such vacancy, the Governor shall have power to fill such vacancy by granting a commission, which shall expire at the end of the next session of the Legislature, or at the next election by the people.

SEc. 9. He may, on extraordinary occasions, convene the Legislature by proclamation, and shall state to both houses, when assembled, the purpose for which they shall have been convened.

SEC. I0. He shall communicate by message to the Legislature, at every session, the condition of the State, and recommend such matters as he shall deem expedient.

SEC. 11. in case of a disagreement between the two houses, with respect to the time of adjournment, the Governor shall have power to adjourn the Legislature to such time as he may thirk proper; Provided it be not beyond the time fixed for the meeting of the next Legislature. 
SEc. 12. No person shall, while holding any office under the United States, or this State, exercise the office of Governor, except as hereinafter expressly provided.

SEc. 13. The Governor shall have the power to grant reprieves and pardons after conviction, for all offences except treason, and cases of impeachment, upon such conditions, and with such restrictions and limitations, as he may think proper, subject to such regulations as may be provided by law relative to the manner of applying for pardons. Upon conviction for treason he shall have the power to suspend the execution of the sentence until the case shall be reported to the Legislature at its next meeting, when the Legislature shall either pardon, direct the execution of the sentence, or grant a further reprieve. $\mathrm{He}$ shall communicate to the Legislature, at the beginning of every session, every case of reprieve, or pardon granted, stating the name of the convict, the crime of which he was convicted, the sentence and its date, and the date of the pardon or reprieve.

SEc. 14. There shall be a seal of this State, which shall be kept by the Governor, and used by him officially, and it shall be called "The Great Seal of the State of California."

SEC. 15. All grants and commissions shall be in the name and by the authority of the people of the State of California, sealed with the great seal of the State, signed by the Governor, and countersigned by the Secretary of State.

SEc. 16. A Lieutenant-Governor shall be elected at the same time and place, and in the same manner as the Governor; and his term of office, and his qualifications, shall also be the same. He shall be Pre- 
sident of the Senate, but shall only have a casting rote therein. If, during a vacancy of the office of Gorernor, the Lieutenant-Governor shall be impeached, displaced, resign, die, or become incapable of performing the duties of his office, or be absent from the State, the President of the Senate shall act as Governor, until the vacancy be filled, or the disability shall cease.

SEC. 17. In case of the impeachment of the Governor, or his removal from office, death, inability to discharge the powers and duties of the said office, resignation or absence from the State, the powers and duties of the office shall devolve upon the LieutenantGovernor for the residue of the term, or until the disability shall cease. But when the Governor shall, with the consent of the Legislature, be out of the State in time of war, at the head of any military forcs thereof, he shall continue commander-in-chief of all the military forces of the State.

SEC. 18. A Secretary of State, a Comptroller, a Treasurer, an Attorney-General and Surveyor-General, shall be chosen in the manner provided in this Constitution; and the term of office, and eligibility of each, shall be the same as are prescribed for the Governor and Lieutenant-Governor.

SEC. 19. The Secretary of State shall be appointed by the Governor, by and with the advice and consent of the Senate. He shall keep a fair record of the official acts of the Legislature and Executive Departments of the Government; and shall, when required, lay the same, and all matters relative thereto, before either branch of the Legislature: and shall perform such other duties as shall be assigned him by law. 
Sec. 20. The Comptroller, Treasurer, AttorneyGeneral and Surveyor-General, shall be chosen by joint vote of the two Houses of the Legislature, at their first session under this Constitution, and thereafter shall be elected at the same time and places, and in the same manner, as the Governor and Lieutenant-Governor.

SEc. 21. The Governor, Lieutenant-Governor, Secretary of State, Comptroller, Treasurer, AttorneyGeneral, and Surveyor-General, shall each at stated times during their continuance in office, receive for their services a compensation, which shall not be increased or diminished during the term for which they shall have been elected; but neither of these officers shall receive for his own use any fees for the performance of his official duties.

\section{ARTICLE VI.}

\section{JUDICIAL DEPARTMENT.}

SEC. 1. The judicial power of this State shall be vested in a Supreme Court, in District Courts, in County Courts, and in Justices of the Peace. The Legislature may also establish such municipal and other inferior courts as may be deemed necessary.

SEc. 2. The Supreme Court shall consist of a Chief Justice, and two Associate Justices, any two of whom shall constitute a quorum.

SEc. 3. The Justices of the Supreme Court shall be elected at the general election, by the qualified electors of the State, and shall hold their office for the term of six years from the first day of January next after their election; provided that the Legisla- 
ture shall, at its first meeting, elect a Chief Justice and two Associate Justices of the Supreme Court, by joint vote of both houses, and so classify them that one shall go out of office every two years. After the first election, the senior Justice in commission shall be the Chief Justice.

Sic. 4. The Supreme Court shall have appellate jurisdiction in all cases when the matter in dispute exceeds two hundred dollars, when the legality of any tax, toll, or impost, or municipal fine is in question : and in all criminal cases amounting to felony, or questions of law alone. And the said court ind each of the Justices thereof, as well as all district and county judges, shall have power to issue writs of habeas corpus, at the instance of any person held in actual custody. They shall also have power to issue all other writs and process necessary to the exercise of the appellate jurisdiction, and shall be conservators of the peace throughout the State.

SEC. 5. The State shall be divided by the first Legislature into a convenient number of districts, subject to such alteration from time to time as the public good may require; for each of which a district judge shall be appointed by the joint rote of the legislature, at its first meeting, who shall hold his office for two years from the first day of January next after his election; after which, said judges shall be elected by the qualified electors of their respective districts, at the general election, and shall hold their office for the term of six years.

SEC. 6. The District Courts shall hare original jurisdiction, in law and equity, in all civil cases where the amount in dispute exceeds two hundred dollars, exclusive of interest. In all criminal cases not other- 
wise provided for, and in all issues of fact joined in the probate courts, their jurisdiction shall be unlimited. SEC. 7. The Legislature shall provide for the election, by the people, of a Clerk of the Supreme Court, and County Clerks, District Attorneys, Sheriffs, Coroners, and other necessary officers; and shall fix by law their duties and compensation. County Clerks shall be, ex-officio, Clerks of the District Courts in and for their respective counties.

SEC. 8. There shall be elected in each of the organized counties of this State, one County Judge who shall hold his office for four years. He shall hold the County Court, and perform the duties of Surrogate, or Probate Judge. The County Judge, with two Justices of the Peace, to be designated according to law, shall hold courts of sessions, with such criminal jurisdiction as the Legislature shall prescribe, and he shall perform such other duties as shall be required by law.

SEc. 9. The County Courts shall hare such jurisdiction, in cases arising in Justices Courts, and in special cases, as the Legislature may prescribe, but shall have no original civil jurisdiction, except in such special cases.

SEc. 10. The times and places of holding the terms of the Supreme Court, and the general and special terms of the District Courts within the several districts, shall be provided for by law.

SEc. 11. No judicial officer, except a Justice of the Peace, shall receive to his own use, any fees, or perquisites of office.

SEC. 12. The Legislature shall provide for the speedy publication of all statute laws, and of such judicial decisions as it may deem expedient; and all 
laws and judicial decisions shall be free for publication by any person.

SEc. 13. Tribunals for conciliation may be established, with such powers and duties as may be prescribed by law; but such tribunals shall have no power to render judgment to be olligatory on the parties, except they voluntarily submit their matters in difference, and agree to abide the judgment, or assent thereto in the presence of such tribunal, in such cases as shall be prescribed by law.

SEc. 14. The Legislature shall determine the number of Justices of the Peace, to be elected in each county, city, town, and incorporated village of the State, and fix by law their powers, duties, and responsibilities. It shall also determine in what cases appeals may be made from Justices' Courts to the County Court.

Sxc. 15. The Justices of the Supreme Court, and Judges of the District Court, shall severally, at stated times during their continuance in office, receive for their services a compensation, to be paid out of the treasury, which shall not be increased or diminished during the term for which they shall have been elected. The County Judges shall also severally, at stated times, receive for their services a compensation to be paid out of the county treasury of their respective countics, which shall not be increased or diminished during the term for which they shall have been elected.

SEc. 16. The Justices of the Supreme Gourt and District Judges shall be ineligible to any other office, during the term for which they shall have been elected.

Scc. 17. Judges shall not charge juries with respect to matters of fact, but may state the testimony and declare the law. 
SEc. 18. The style of all process shall be "The People of the State of California;" all the prosecutions shall be conducted in the name and by the authority of the same.

\section{AR'TICLE VII.}

\section{I L I T I A.}

SEc. 1. The Legislature shall provide by law, for organizing and disciplining the militia, in such manner as they shall deem expedient, not incompatible with the constitution and laws of the United States.

SEc. 2. Officers of the militia shall be elected, or appointed, in such manner as the Legislature shall from time to time direct; and shall be commissioned by the Governor.

SEC. 3. The Governor shall have power to call forth the militia, to execute the laws of the State, to fun. press insurrections, and repel invasions.

\section{A RTICLE VIII.}

\section{STATE DEBTS.}

The Legislature shall not in any manner create any debt or debts, liability or liabilities, which shall singly, or in the aggregate, with any previous debts or liabilities exceed the sum of three hundred thousand dullars, except in case of war, to repel invasion, or suppress insurrecton, unless the same shall be authorized by some law for some single object or work, to be distinctly specified therein, which law shall provile ways and means, exclusire of loans, for the payment of the interest of such debt or liability, as it falls due, and also pay and discharge the principal of such debt or 
liability within twenty years from the time of the contracting thereof, and shall be irrepealable until the principal and interest thereon shall be pail and dis. charged; bat no ruch law shall take effeet until, at a general election, it shall have been suhinitted to the people, and have reeeived a unajority of all the rotes cast for and against it at pueh election; snd sll money raiked by authurity of such law slatl be applied only to the specifie object therein statod, or to the payment of the thebt therelyy created; and sach law shall be published in at least one newspapor in sach judicial distriet, if one be publiahed therein, throughout the State, for three unonths next preceding the election at which it is submitted to the people.

\section{ARTICLE IX.}

EDCCATIOX.

Snc. 1. The Leginlature sliall provile for the clection, by the peuple, of a Superintendent of Publie Instruetion, who shall hold bis vffee for three years, sad shose ducies shall be prescribed by law, and who shall receive such compeusation as the Legialature may direct.

Sxc. 2. The Iegislarure shall encourage, by all suitable meank, the promotion of intelleotmul, scientific, moral and agriculnral improvenent. The proceeds of all lands that may be granted ly the Lnited States to this State for the soppert of schools, which uny be sold or disponed of, and the five loumlred thousend scres of land granted to the new 8tates, under an act of Congress distributing the procesds of the public lands among the several States of the Cnion, approved A. D. 1841 ; and all eatates of deceased persons who 
may hare died without leaving a will, or heir, and also such per cent. as may be granted by Congress on the sale of lands in this State, shall be and remain a perpetual fund, the interest of which, together with all the rents of the unsold lands, and such other means as the Legislature may provide, shall be inviolably appropriated to the support of Common Schools throughout the State.

SEc. 3. The Legislature shall provide for a system of Common Schools, by which a school shall be kept up and supported in each district at least three months in every year: and any school district neglecting to keep up and support such a school, may be deprived of its proportion of the interest of the public fund during such neglect.

SEc. 4. The Legislature shall take measures for the protection, improvement, or other disposition of such lanils as have been, or may hereafter be, reserved or granted by the United States, or any person or persons to this State for the use of a Unirersity ; and the funds accruing from the rents or sale of such lands, or from any other source, for the purpose aforesaid, shall be and remain a permanent fund, the interest of which shall be applied to the support of said university, with such branches as the public convenience may demand for the promotion of literature, the arts and sciences, as may be authorized by the terms of suen grant. And it shall be the duty of the Legislature, as soon as may be, to provile effectual means for the improvement and permanent security of the funds of said University. 


\section{ARTICLE X.}

\section{MODE OF AMENDING AND REVISING TII C ONSTITUTION.}

SEC. 1. Any amendment or amendments to this Constitution may be proposed in the Senate or Assembly; and if the same shall be agreed to by a majority of the members elected to each of the two houses, such proposed amendment or amendments shall be entered on their journals, with the yeas and nays taken thereon, and referred to the Legislature then next to be chosen, and shall be published for three months next preceding the time of making such choice. And if, in the Legislature next chosen, as aforesaid, such proposed amendment or amendments shall be agreed to by a majority of all the members elected to each house, then it shall be the duty of the Legislature to submit such proposed amendment or amentments to the people, in such manner, and at such time, as the Lepislature shall prescribe; and if the people shall approve and ratify such amendment or amendments, by a majority of the electors qualified to rote for members of the Lecrislature roting thereon, such amendment or amendments shall become part of the Constitution.

SEc. 2. And if, at any time, two-thiris of the Senato and Assembly shall think it necessary to rerise and change this entire Constitution, they shall recommend to the electors, at the next clection for members of the Legislature, to rote for or against the conrention; and if it shall appear that a majority of the electors roting at such election have rotel in faror of calling a convention, the Legislature shall, at its next session, provide by law for calling a convention, to be holden 
within six months after the passage of such law; and such convention shall consist of a number of members not less than that of both branches of the Legislature.

\section{ARTICLE XI.}

MISCELLANEOUS PROVISIONS.

SEc. 1. The first session of the Legislature shall be held at the Pueblo de San Jose, whioh place shall be the permanent seat of government, until removed by law; provided, however, that two-thirds of all the members elected to each house of the Legislature shall concur in the passage of such law.

SEC. 2. Any citizen of this State who shall, after the adoption of this Constitution, fight a duel with dcadly weapons, or send or accept a challenge to fight a duel with deadly weapons, either within the State or out of it; or who shall act as second, or knowingly aid or assist in any manner those thus offending, shall not be allowed to hold any office of profit, or to enjoy the right of suffrage under this Constitution.

SEc. 3. Members of the Legislature, and all officers, exccutive, and judicial, except such inferior officers as may be by law exempted, shall, before they enter on the duties of their respective offices, take and subscribe the following oath or affirmation.

"I do solemnly swear (or affirm, as the case may be, ) that I will support the Constitution of the United States, and the Constitution of the State of California: and that I will faithfully discharge the duties of the office of — , according to the best of my ability." And no other oath, declaration, or test, shall be required as a qualification for any office or public trust. 
SEc. 4. The Lecislature shall cetablish a system of county and town gorernucints, which shall be as nearly uniform as practicable, throughout the Statc.

SEc. 5. The Legislature shall have power to provide for the election of a board of supervisors in each county; and these supervisors shall, jointly and individually, perform such duties as may be prescribed by law.

SEC. 6. All officers whose election or appointment is not provided for by this constitution, and all officers whose offices may hereafter be created by law, shall be electerl by the people, or appointed as the Legislature may direct.

Si:c. 7. When the duration of any office is not provided for by this constitution, it may be declared by law; and of not so declared, such office shall be held during the pleasure of the anthority making the appointment; nor shall the duration of any office, not fixed by this constitution, ever exceed four years.

SEC. 8. The fiscal year shall commence on the first day of July.

SEc. 9. Each county, tomn, city, and incorporated village, shall make provision for the support of its own officers, subject to such restrictions and regulations as the Legislature may prescribe.

SEc. 10. The crellit of the State shall not in any manner be given or loaned to, or in aid of, any individual, association, or corporation; nor shall the State, clirectly or indircetly, hecome a stockholder in any association or corporation.

SEc. 11. Suits ma be brought against the State, in such manner, and ju such courts, as shall be dirceted by law.

SEC. 12. No contract of marriage, if otherwiso $35 *$ 
duly made, shall be invalicated, for want of conformity to the recuirements of any religious sect.

SEC. 13. Taxation shall be erpual and uniform throughout the Etate. All property, in this State, shall be taxed in proportion to its value, to be ascertained as directed by liaw; but assessors and collectors of town, county, and State taxes, shall be eleeted by the qualified clectors of the district, county, or town, in which the property taxed for State, comnty, or town purposes is situated.

SEC. 14. All property, both real and peranal, of the wife, ormed or claimed by her before marriage, and that acquired afterwards hy gift, devise, or descent, shall be hor separato property; and laws shall be passed more olearly defining the rights of the wife, in relation as well to bor suparate property, as to that held in common with hoe husband. Laws shall also be passed providing for the restoration of the wife's separate property.

SEC. 15. The Legislature shall protect by law, from forced sale, a certain portuin of the lhomesteal and other property of all heads of families.

SEC. 16. No perpetuitics shall be allowed, except for eleemosynary purposes.

SEc. 1\%. Wrery person shall be disqualified from holding any office of profit in this State, who shall have been convicted of having eriven or offered a bribe, to procure his election or appointinent.

SEc. 18. Lams shall be mode to exclude from office, scrving on jurics, and from the right of swifrage, those who shall hereaftur be convictod of bribery, lerjury, forgery, or other high crimes. The privilege of free suffrage shall be supported by laws regulating clcctions, and prohibiting, under adecquate penalties, all 
undue influence Lereon, from power, bribery, tumult, or other improper practice.

SEc. 19. Absence from this State on business of the State, or of the Cnited States, shall not affect the question or residence of any person.

SEc. 20. A plurality of the rotes given at any election shall constitute a choice, where not otherwise directed in this constitution.

SEc. 21. All laws, decrees, regulations and provisions, which from their nature require publication, shall be published in English and Spauish.

\section{ARTICLE XII.}

B O U N D R Y.

The boundary of the State of California shall be as follows:-

Commencins at the point of intersection of the $42 \mathrm{~d}$ decree of nurth latitule with the 120th degree of longitule west from Greenwich, and runing south on the line of sidil 120th deerree of west longiturle until it intersects the 89 th decree of north latitude; thence rumning in a straight line in a sonth-easterly direction to the River Coloralo, at a point where it intersects the 35th degree of larth latitule; thence down the middle of the channel of said river. to the l,oundiry line between the United States and Mexico, as established by the treaty of Itay 30 th, 1845; thence rumning west and along said boundary line to the Pacifie Occan, and extending therein three English miles; thence ruming in a north-westerly direction, and following the direction of the Pacifie coast to the 42,1 degree of north latitude; thence oir the line of sair $42 d$ degree of north latitude to the place of beginning. 
Alsn all the islands, harbors and bays, along and adjacent to the Pacific coast.

S C H E D L E.

SEc. 1. All richts, prosecutions, claims and contracts, as well of individuals as of bodies corporate, and all laws in force at the time of the adoption of this Constitution, and not inconsistent therewith, until altered or repealed by the Legislature, shall continue as if the same had not been adopted.

SEC. 2. The Legislature shall provide for the removal of all causes which may be pending when this Constitution goes into effect, to courts created by the same.

SEc. 3. In orler that no inconvenience may result to the public service, from the taking effect of this Constitution, no office shall be superseded thereby, nor the laws relative to the duties of the several officers be changed, until the entering into office of the new offieers to be appointed under this Constitution.

SEc. 4. The prorisions of this Constitution concerning the term of residence necessary to enable persons to hold certain offices therein mentioned, shall not be held to apply to officers chosen by the people at the first election, or by the Legislature at its first session.

SEc. 5. Every citizen of California, declared a legal voter by this Constitution, and every citizen of the United States, a resident of this State on the day of election, shall be entitled to rote at the first general election under this Constitution, and on the question of the adoption thereof.

Sec. 6. This Constitution shall be submitted to the people, for their ratification or rejection, at the 
general election to be held on Tuesday, the thirteenth day of November naxt. The Executive of the existing government of California is hereby requested to issue a proclanation to the people, directing the Prefects of the sereral districts, or in case of vacancy, the Sub-Prefects, or senior Judge of First Instance, to cause such clection to be held, on the day aforesaid, in their respective districts. The election shall be conducted in the manner which was prescribed for the election of delegates to this convention, except that the Prefect, Sub-Prefect, or senior Julge of First Instance ordering such election in each district, shall have power to designate any additional number of places for opening the polls, and that, in every place of holdirig the election, a regular poll-list shall be kept by the judges and inspector's of election. It shall also be the duty of these judges and inspectors of electirn, on the day aforesaid, to receive the rotes of the clectors qualified to rote at such election. Each voter shall express his opinion, by depositing in the ballot-box a ticket, whereon shall be written, or printed "For the Constitution," or "Against the Constitution," or some such words as will distinctly conrey the intention of the roter. These Julges and Inspectors shall also receive the rotes for the several officers to be roted for at the said election, as herein proviled. At the close of the election, the judges and inspectors shall carefully count each ballot, and forthwith make duplicate returns thereof to the Prefect, SubPrefect, or scuior Judge of First Instance, as the case may be, of their respective disticts; and sad Prefect, sulo-Prelect, or senior Julge of Fis Linstance shall transinit one of the same, by the most safe and rapid conveyance, to the Secretary of State. Upon 
the receipt of said returns, or on the tenth day of Decenber next, if the returns be not sconer receired, it shall he the duty of a board of canvassers, to consist of the Secretary of State, one of the Jutges of the Superior Court, the Prefect, Julge of First Instance, and an Alealle of the District of Monterey, Oir any three of the aforementioned officers, in the presenee of all who shiall choose to attend, to compare the rotes given at said election, and to immediately publish an abstract of the same in one or more of the newspapers of California. Ant the Executive will also, immediately after ascertaining that the Constitution has been ratified by the people, make proclamation of the fact; and thenceforth this Consitution shall be ordained and established as the Constitution of California.

SEC. 7. If this Constitution shall be ratificd by the peorle of California, the Executive of the existing govermment is hereloy requested, immediat ly after the same shall be ascertained, in the manner herein directenl, to camse a fair copy thereof to be forwarded to the President of the United States, in order that he may lay it before the Congress of the United States.

SEC. 8. At the general election aforesair, riz: the thirteenth day of Normber next, there shall be elected a Gorernor, Lientenant-Governor, menbers of the Legislature, and also two members of Congress.

SEc. 9. If this constitution shall be ratified by the pcople of California, the Legislature shall assemble at the seat of gorernment, on the fiftecnth day of December next, and in order to complete the organization of that body, the Senate shall elect a Presi- 
dent pio tempore, until the Lieutenant-Gorcmor shall be installed into office.

SEe. 10. Un the orguization of the Legi-lature, it shall be the thaty of the Secretary of state, to lay before cach lonse a cony of the alstract mate by tho board of canvassers, and, if called for, the original returns of election, in orter that each house ma judgo of the correctness of the report of said boand of canvassers.

SEc. 11. The Lozislature, at its frst sesim, siall elont such nflows an moy he reteren by this Conatinttime tre la clecterl by thet lonly, and within four inys aftor it orgenimation, procesel to deet two senators

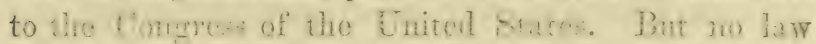
pasact by this degislature shall take offect until :igned by tho fowernon: afer his installarion into aflice.

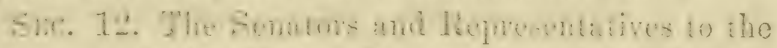
Congreas of the United States, chmed by the Lir-

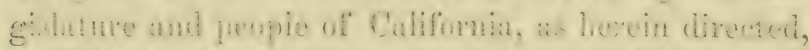

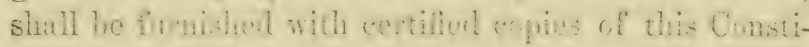
tution, when ralifenl, which they almbl hy before the Congres of the Tritud States, raque ting, in the name

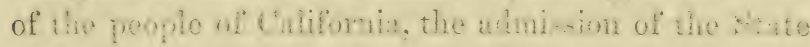
of California into the Amorican Union.

SEr. 13. An witiens of this Sta:e, wher then mon-

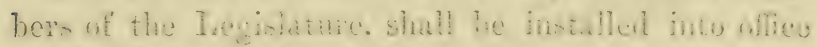
on the firmeniti dar of Decomber nent, or as won thereafter as practicable.

SEo. 1t. Until the Legialuture shall fivide the

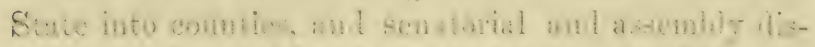

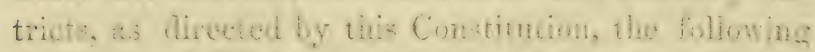

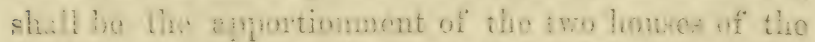

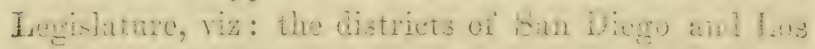
Angeles shial jomty clect two senators: the distriets 
of Santa Barbara and San Luis Obispo shall jointly elect one senator; the district of Monterey, one senator; the district of San Jose, one senator; the district of San Franciseo, two senators; the district of Sonoma, one senator; the district of Sacramento, four senators; and the district of San Joaquin, four senators:-And the district of San Diego shall elect one member of assenbly; the district of Los Angeles, two members of assembly; the district of Santa Barbara, two members of assembly; the district of San Luis Obispo, one nember of assembly; the district of Monterey, two members of assembly; the district of San Jose, three members of assembly; the district of San Francisco, five members of assembly; the district of Sonoma, two members of assembly; the district of Sacramento, nine members of assembly; and the district of San Joaquin, nine members of assembly.

SEc. 15. Until the Lerislature shall otherwise direct, in accordance with the provisions of this Constitution, the salary of the Governor shall be ten thousand dollars per annum; and the salary of the LieutenantGorernor shall be double the pay of a state senator; and the pay of members of the Legislature shall be sixteen dollars per diem, while in attendance, and sixteen dollars for every twenty miles travel by the usual route from their resilences, to the place of holding the session of the Legislature, and in returning therefrom. And the Legislature shall fix the salaries of all officers, other than those elected by the people, at the first election.

SEC. 16. The limitation of the powcrs of the Legislature, contained in article 8 th of this Constitution, tution, shall not extend to the first Legislature elected 
under the same, which is hereby authorized to negotiate for such amount as may be necessary to pay the expenses of the State government.

\section{R. SEMPLE,}

President of the Convention and Delegate from Benecia.

Wy. G. MARcy, Secretary.

J. Aram,

C. T. Botts,

E. Brown,

J. A. Carillo,

J. M. Covarrubias,

E. O. Crosby,

P. De La Guerra,

L. Dent,

M. Dominguez,

K. H. Dimmick,

A. J. Ellis,

S. C. Foster,

E. Gilbert,

W. M. Gwinn,

H. W. Halleck,

Julian Hanks,

L. W. Hastings,

Henry Hill,

J. Hobson,

J. McH. Hollingsworth,

J. D. Hoppe,

J. M. Jones,

1. O. Larkin.

Francis J. Lippitt,
B. S. Lippincott, M. M. McCarver, John McDougal,

B. F. Noore,

Myron Norton,

P. Ord,

Miguel Pedrorena,

A. M. Pico,

R. M. Price,

Hugo Reed,

Jacinto Rodriguez,

Pedro Sansevaine,

W. E. Shannon,

W. S. Sherwood,

J. R. Snyder,

A. Stearns,

W. M. Steuart,

J. A. Sutter,

Henry A. Tefft,

S. L. Vermule,

M. G. Vallejo,

J. Walker,

O. M. Wozencraft. 


\section{B.}

\section{ADDRESS TO THE PEOPLE OF CALIFORNIA.}

The undersigned, delegates to a convention authorized to form a Constitution for the State of California, having, to the best of their ability, discharged the high trust committed to them, respectfully submit the accompanying plan of governinent for your approval. Acknowledging the great fundamental principles, that all political power is inherent in the people, and that government is instituted for the protection, security and benefit of the people, the Constitution presented for your consideration is intended only to give such organic powers to the several departments of the proposed government, as shall be necessary for its efficient administration: and while it is believed no power has been given, which is not thus essentially necessary, the convertion deem individual rights, as well as public liberty, are amply secured, by the people still retaining not only the great conservative power of free choice and election of all officers, agents, and representatives, but the unalienable right to alter or reform their government, whenever the public good may require.

Although born in different climes, coming from different States, imbued with local feelings, and educated, perhaps, with predilections for peculiar institutions, laws, and customs, the delegates assembled in convention as Californians, and carried on their deliberations in a spirit of am:ty, compromise, anil mutual concession for the public weal.

It cannot be denied that a difference of opinion was entertained in the convention, as to the policy and 
expediency of sereral measures embodied in the Constitution; but looking to the great interests of the State of California, the peace, happiness, and prosperity of the whole people,-individual opinions were freely surrendered to the will of the majority, and, with one roice, we respectfully but carnestly recommend to our fellow citizens the adoption of the Constitution which we have the honor to submit.

In establishing a bounlary for the State, the convention conformed, as near as was deemed practicable and expeclient, to great natural landmarks, so as to bring into a union all those who should be included by mutual interest, mutual wants, and mutual dependence. No portion of territory is included, the inhabitants of which were not or might not have been legitimately represented in the convention, under the authority by which it was convened; and in unanimously resolving to exclude slavery fiom the State of California, the great principle has been maintained, that to the people of each State and Territory, alone, belongs the right to establish such municipal regulations, and to decide such questions as affect their own peace, prosperity and happiness.

A free people, in the enjoyment of an elective government, capable of securing their civil, religious, and political rights, may rest assured these inestimable pririleges can never be wrested from them, so long as they keep a watchful eye on the operations of their government, and hold to strict accountability those to whom power is delegated. To people were ever yet enslared, who knew and dared maintain the co-relative rights and obligations of free and independent citizens. A knowledge of the laws-their moral force and effcacy, thus becomes an essential element of freedom, 
and makes public education of primary importance. In this view, the Constitution of Califurnia provides for, and guarantees in the most ample manner, the establishment of common schools, seminaries and colleges, so as to extend the blessings of education throughout the land, and secure its advantages to the present and future generations. Under the peculiar circumstances in which California becomes a Statewith an unexampled increase of a population coming from every part of the world, speaking various languages, and imbued with different feelings and prejudices, no form of government, no system of laws, can be expected to meet with immediate and unanimous assent. It is to be remembered, moreover, that a considerable portion of our fellow-citizens are natives of Old Spain, Californians, and those who have voluntarily relinquished the rights of Mexicans to enjoy those of American citizens. Long accustomed to a different form of government, regarding the rights of person and of property as interwoven with ancient usages and time-honored customs, they may not at once see the advantages of the proposed new government, or yield an immediate approval of new laws, however salutary their provisions, or conducive to the general welfare. But it is confidently believed, when the government as now proposed shall have gone into successful operation, when each department thereof shall move on harmoniously in its appropriate and respective sphere, when laws, based on the eternal principles of equity and justice, shall be established, when every citizen of California, shall find himself secure in life, liberty, and property-all will unite in the cordial support of institutions, which are not only the pride and boast of every true-hearted citizen of the 
Union, but have gone forth, a guiding light to every people groping through the gloom of religious su, erstition or political fanaticism-institutions, which even now, while all Europe is agitated with the convulsive efforts of nations battling for liberty, have become the mark and model of government for every people who would hold themselves free, sovereign, and indepencient.

With this brief exposition of the views and opinions of the convention, the undersigned submit the Constitution and plan of government for your approval. They earnestly recommend it to your calm and deliberate consideration, and especially do they most respectfully urge on every voter to attend the polls.

The putting into operation of a government which shall establish justice, insure domestic tranquillity, promote the general welfare, and secure the blessings of civil, religious, and political liberty, should be an object of the deepest solicitude to every true-hearted citizen, and the consummation of his dearest wishes. The price of liberty is eternal vigilance, and thus it is not only the privilege but the duty of every voter to vote his sentiments. No freeman of this land who values his birthright, and would transmit unimpaired to his children an inheritance so rich in glory and honor, will refuse to give one day to the service of his country. Let every qualified voter go early to the polls, and give his free rote at the election appointed to be held on Tuesday, the 13th day of November next, not only that a full and fair expression of the public voice may be had, for or against a constitution intended to secure the peace, happiness and prosperity of the whole people, but that their numerical and political strength may be made manifest, and the world see by what majority of freemen California, 
the bright star of the West, claims a place in the diadem of that glorious republic, formed by the Union of thirty-one sovereign States.

(Signed)

Joseph Aram,

Chas. T. Botts,

Elam Brown,

Jose Anto. Carillo,

Jose M. Covarrubias,

Elisha 0. Crosby,

Lewis Dent,

Manuel Dominguez,

K. H. Dimmick,

A. J. Ellis,

Stephen G. Foster,

Pablo De La Guerra,

Benj. S. Lippincott,

M. M. McCarver,

John McDougal,

Benj. F. Moore,

Myron Norton,

P. Ord,

Miguel De Pedrorena,

Rodman M. Price,

Antonio M. Pico,

Jacinto Rodrigues,

Hugh Reed,

John A Sutter,
Edw. Gilbert,

Wm. M. Gwin,

Julian Hanks,

Henry Hill,

J. D. Hoppe,

Joseph Hobson,

H. W. Halleck,

L. W. Hastings,

J. MeH. Hollingsworth,

Jas. MeHall Jones,

Thomas 0. Larkin,

Francis J. Lippitt,

Jacob R. Snyder,

W. Scott Sherwood,

Wm. C. Shannon,

Pedro Sansevain,

Abel Stearns,

W. M. Steuart,

R. Semple,

Henry A Tefft,

M. G. Vallejo,

Thos. L. Vermule,

Joel P. Walker,

O. M. Wozencraft. 


\section{MIESSAGE FROM THE PRESIDENT OF THE UNITED STATES,}

Transmitting information in answer to a resolution of the House of the 31st of December, 1849, on the subject of California and Nero Mexico.

To the House of Representatives of the Uxited States.-I transmit to the House of Representatives, in answer to a resolution of that body passed on the 31st of December last, the accompanying reports of heads of departments, which contain all the official information in the possession of the Executive asked for by the resolution.

On coming into office, I found the military commundant of the department of California exercising the functions of ciril governor in that Territory; and left, as I was, to act under the treaty of Guadalupe IIidalgo, withont the aid of any legislative prorision establishing a government in that Territory, I thought it not best to disturb that arrangement, made unler my predecessor, until Congress should take some action on that subject. I therefore did not interfere with the powers of the military commandant, who continued to exercise the functions of ciri] governor as before; but I made no such appointment, conferred no such authority, and hare allowed no increased compensation to the commandant for his services.

With a view to the faithful execution of the treaty, so far as lay in the power of the Executive, and to enable Congress to act, at the present session, with as 
full knowledge and as little difficulty as possible, on all matters of interest in these Territories, I sent the honorable Thomas Butler King as bearer of despatches to California, and certain officers to California and New Mexico, whose duties are particularly defined in the accompanying letters of instruction addressed to them severally by the proper departments.

I did not hesitate to express to the people of those Territories my desire that each Territory should, if prepared to comply with the requisitions of the Constitution of the United States, form a plan of a State Constitution and submit the same to Congress, with a prayer for admission into the Union as a State; but I did not anticipate, suggest, or authorize the establishment of any such government without the assent of Congress; nor did I authorize any government agent or officer to interfere with or exercise any influence or control over the election of delegates, or over any convention, in making or modifying their domestic institutions, or any of the provisions of their proposed Constitution. On the contrary, the instructions given by my orders were, that all measures of domestic policy adopted by the people of California must originate solely with themselves; that while the Executive of the United States was desirous to protect them in the formation of any government republican in its character, to be at the proper time, submitted to Congress, yet it was to be distinctly understood that the plan of such a government must, at the same time, be the result of their own deliberate choice, and originate with themselves, without the interference of the Executive.

I am unable to give any information as to laws passed by any supposed government in California, or 
of any census taken in either of the Territories mentioned in the resolution, as I have no information on those subjects.

As already stated, I have not disturbed the arrangements which I found had existed under my predecessor.

In advising an early application by the people of these Territories for admission as States, I was actuated principally by an earnest desire to afford to the wisdom and patriotism of Congress the opportunity of aroiding occasions of bitter and angry dissensions among the people of the United States.

Under the Constitution, every State has the right of establishing, and, from time to time, altering its municipal laws and domestic institutions, independently of every other State and of the general government; subject only to the prohibitions and guaranties expressly set forth in the Constitution of the United States. The subjects thus left exclusively to the respectire States were not designed or expected to become topics of national agitation. Still, as, under the Constitution, Congress has power to make all needful rules and regulations respecting the Territories of the United States, every new acquisition of territory has led to discussions on the question whether the system of involuntary servitude which prevails in many of the States should or should not be prohibited in that Territory. The periods of excitement from this cause which have heretofore occurred have been safely passed; but during the interval, of whatever length, which may elapse before the admission of the Territories ceded by Mexico as States, it appears probable that similar excitement will prevail to an undue extent. 
Under these circumstances, I thought, and still think, that it was my duty to endearor to put it in the power of Congress, by the admission of California and New Mexico as States, to remore all occasion for the unnecessary agitation of the public mind.

It is understood that the people of the western part of California have formed a plan of a State Constitution, and will soon submit the same to the judgment of Congress, and apply for admission as a State. This course on their part, though in accordance with, was not adopted exclusively in consequence of, any expression of my wishes inasmuch as measures tending to this end had been promoted by the officers sent there by my predecessor, and were already in active progress of execution before any communication from me reached California. If the proposed Constitution shall, when submitted to Congress, be found to be in compliance with the requisitions of the Constitution of the United States, I earnestly recommend that it may receive the sanction of Congress.

The part of California not included in the proposed State of that name is believed to be uninhabited, except in a settlement of our countrymen in the vicinity of Salt Lake.

A claim has been advanced by the State of Texas to a very large portion of the most populous district of New Mexico. If the people of New Mexico had formed a plan of a State government for that Territory as ceded by the treaty of Guadalupe Hidalgo, and had been admitted by Congress as a State, our Constitution would have afforded the means of obtaining an adjustment of the question of boundary with Texas by a judicial decision. At present, however, no judicial tribunal bas the power of deciding that 
question, and it remains for Congress to derise some mode for its arljustment. Meanwhile, I submit to Congress the question whether it wonld be experlient, before such adjustment, to establish a territorial government, which, by incluling the district so claimed, would practically decide the question adversely to the State of 'Texas, or, by excluding it, would decide it in her faror. In my opinion, such a course would not be expedient, especially as the people of this Territory still enjoy the benefit and pro. tection of their municipal laws, originally derived from Mexico, and have a military force stationed there to protect them against the Indians. It is undoubtedly true that the property, lives, liberties, and religion of the people of New Mexico are better protected than they erer wore before the treaty of cession.

Should Congress, when California shall present herself for incorporation into the Union, annex a condition to her admission as a State affecting her domestic institutions, contrary to the wishes of her people, and even compel her temporarily, to comply with it, yet the State, could change her Constitution at any time after admission, when to her it snould seem expedient. Any attempt to deny to the people of the State the right of self-government, in a matter which peculiarly affects themselves, will infallibly be regarded by them as an invasion of their rights; and, upon the principles laid down in our own Declaration of $T_{i}$ dependence, they will certainly be sustained by the gxeat mass of the American people. To assert that they are a conquered people, and must, as a State, submit to the will of their conquerors in this regard, will meet with no cordial response among American freemen. Great numbers of them are na- 
tive citizens of the United States not inferior to the rest of our countrymen in intelligence and patriotism; and no language of menace, to restrain them in the exercise of an undoubted right, guarantied to them by the treaty of cession itself, shall ever be uttered by me, or encouraged and sustained by persons acting under my authority. It is to be expected that, in the residue of the Territory ceded to us by Mexico, the people residing there will, at the time of their incorporation into the Union as a State, settle all questions of domestic policy to suit themselves. No material inconvenience will result from the want, for a short period, of a government established by Congress over that part of the Territory which lies eastward of the new State of California; and the reasons for my opinion that New Mexico will, at no very distant period, ask for admission into the Union, are founded on un-official information, which, I suppose, is common to all who have cared to make inquiries on that subject.

Seeing, then, that the question which now excites such painful sensations in the country will, in the end, certainly be settled by the silent effect of causes independent of the action of Congress, I again submit to your wisdom the policy recommended in my annual message, of awaiting the salutary operation of those causes, believing that we shall thus avoid the creation of geographical parties, and secure the harmony of feeling so necessary to the beneficial action of our political system. Connected as the Union is with the remembrance of past happiness, the sense of present blessings, and the hope of future peace and prosperity, every dictate of wisdom, every feeling of duty, and every emotion of patriotism, tend to inspire fidelity and devotion to it, and admonish us cautiously to avoid 
any unnecessary controversy which can either endanger it or impair its strength, the chief element of which is to be found in the regard and affection of the people for each other.

\section{Z. TAYLOR.}

Washington City, D. C., January 21st, 1850.

\section{D.}

Executive Departirent of Califoria, Monterey, August 30, 1849.

Geveral :-I have the honor to transmit, herewith, copies of civil papers and letters issued by me since my despatch of June 30, and to continue my report on the civil affairs of this country from this date.

Accompanied by Captain Halleck, Secretary of State for California, and Major Canby, Captain Wescott, and Lieutenant Derby, of my military staff, I left this place on the 5th July for the purpose of inspecting the military posts in the interior, and of learning from personal observation the actual state of affairs in the mineral regions, and also of allaying, so far as I could, the hostile feeling which was said to exist between the Americans and foreigners who were working in the gold placers. My report on the state of the troops and a more detailed account of my tour will be forwarded with my military papers.

Passing the mission of San Juan Bautista, we crossed the coast range of mountains near the ranche of Senor Pacheco, and struck the San Joaquin River near the mouth of the Merced; and, after visiting Major Miller's camp on the Stanislaus, we procected to examine the principal placers on the tributaries of 
that river and of the Tuolumne. These washings or diggings have been among the richest and most productive in California.

They are situated within a circuit of some twelve or fifteen miles, and are known as Jamestown, Wood's Creek, Sonoranian Camp, Sullivan's Creek, Curtis's Creek, French Creek, Carson's Creek, and Angelo Creek. Some of these have become places of considerable business, particularly the Sonoranian Camp, which presents the appearance of a city of canvas houses.

Passing the Stanislaus River in the mountains, we proceeded to Major Kingsbury's camp near the mouth of the American River, crossing in our route the Calaveras, Moquelume, Seco, and Cosumnes Rivers; all of which have rich washings near their sources, and on their bars and islands. From Major Kingsbury's camp we ascended the American River to Cullamo Hills, where the first placer was discovered by Captain Sutter's employees in the spring of 1848. From Cullamo we crossed the country to Stockton, a new town on an estero some distance above the mouth of the San Joaquin, and thence proceeded to Colonel Cazey's camp at the straits of Carquinnes; returning via San Francisco to Monterey, which place we reached on the afternoon of the 9th instant.

We found the country at this season dry and parched by the sun, the heat of which became very great the moment we crossed the coast range of mountains. The thermometer ranges as high as $113^{\circ} \mathrm{Fah}$. in the shade, and above $140^{\circ}$ Fah. in the sum. A great portion of the valley of the Joaruin is so barren as scarcely to afford subsistence for our animals, and can never be of much value for agricultural purposes. There, however, is, some excellent land on the east 
side of that river, borloring its large tributarics. A considerable prertion of the valleys of the Moquelume, Seco, Costmes, and American Rivers is also well adapted to agriculture; and the broad plains lying between them furnish abunciant pasture for raising stock. But the amount of good arable land, as compared with the extent of country which we passed over, is small, and I am inclined to believe that the richness and extreme fertility of certain localities have led to erroneous conclusions respecting the general character of the country. Certain it is, that while there may be found sufficient arable lands to support, if well cultivated, a numerous population, here is also a very great extent of rough and mountainous country and sandy and barren plains which are of little value. The great difficulty to be encountered in agricultural pursuits in some portions of California is the want of water for irrigation; but possibly this difficulty may be overcome in part by resorting to artesian wells. If so, much of the public land which is now unsaleable may be brought into market, and the settlement of the country greatly accelerated. I would, therefore, suggest whether it may not be advisable for our government to direct some experiments to be made at the public expense in sinking wells of this character, for even if unsuccessful as a means of irrigation, their construction will greatly assist in determining the geological character of the country. At present nearly all agricultural labors are suspended in the general scramble for goll ; but the enormous prices paid for fruit and regetalles in the towns will undoubtedly induce many, during the coming year, to turn their attention to the cultivation of the soil. The failure on the part of Congress, 
at its last session, to authorize the sale of public lands in California, has proved detrimental to the agricultural interest of the country.

A large number of those who have recently emigrated to California are desirous to locate themselves permanently in the country, and to cultivate the soil, but the uncertainty which exists with respect to the validity of land titles in California, and to what actually constitutes the public domain, serves as a scrious check to the forming of new agricultural settlements; moreover, speculators are purchasing up fraudulent and invalid titles to large tracts of the public domain, and selling them off in parcels, and at enormous profits, to those who have recently arrived in the country, and who are necessarily ignorant of the real state of the case. All the mission lands in California were secularized, or made government property, by a law of Mexico, dated August 17th, 1833, and the territorial government of California, under the authority of the Mexican laws, leased and sold a portion of these lands and mission property. Another portion of this property, however, still remained unsold when the Americans took possession of the country, and it has since been left in the hands of government agents for preservation. Erroneously supposing that these lands are subject to pre-emption laws, some of the recent emigrants have attempted to settle upon them.

But I cannot deem myself justifiable in permitting this, for I do not conceive that lands which have been under cultivation for half a century, and now belong to government, can be subject to the pre-emption claims of private individuals, in the same manner as the uncultivated lands of the public domain. It is, howerer, important for the interest of the country that 
these mission lands be brought into market with the least possible delay, and also that provision be made by law for the settlement and sale of other public lands in California. And as disputes are almost daily occurring between individuals respecting the extent of their sereral claims, and the ralidity of their titles, I would urge upon our gorernment the necessity of immediately taking measures for the speedy and final settlement of these titles upon principles of equity and justice. This is absolutely essential for the peace and prosperity of the country.

For information connected with this subject, I beg leave to call attention to the report of Captain Halleck, Secretary of State for California, which was forwarded to Washington by my predecessor, in the early part of April last.

Before leaving Monterey I heard numerous rumors of irregularities and crimes among those working in the placers; but, on visiting the mining regions, I was agreeably surprised to learn that every thing was quite the reverse from what had been represented, and that order and regularity wero preserved throughout almost the entire extent of the mineral districts. In each little settlement, or tented town, the miners have elected their local alcaldes and constables, whose judicial decisions and official acts are sustained by the people, and enforced with much regularity and cnergy. It is true, that in a few instances certain local questions have produced temporary excitements and dificulties, but none of these have been of a rery important character, or led to serious results. Alcaldes haro probably in some cases, and under peculiar circumstances, exercised judicial powers which were never conferred upon them by law; but the general result 
has been farorable to the preservation of order and the dispensation of justice.

The old placers are still exceedingly productive, and new ones are almost daily discovered in the smaller streams running from the western slope of the Sierra Nevada into the great valleys of the Sacramento and San Joaquin Rivers.

I am satisfied, howerer, from personal observation, that very exaggerated accounts have been sent to the United States respecting the ease with which the precious metal is extracted from the earth, and that many who come to this country with the expectation of acquiring sudden wealth, with little or no labor, will be sadly disappointed. It is true that the reward of labor in the mines is very high; but it should not be forgotten that gold digging and gold washing in that climate require strong constitutions and great physical exertions, and very few need cxpect to acquire fortunes by working the placers, without severe labor and fixed habits of industry and temperance. The yield of different localities is, of course, very different, some of the placers being exceedingly rich, while the product of others is scarcely suficient to pay the expenses of working. But $I$ think the general averages per diem, for those actually employed in washing for gold, will not vary much from an ounce or an ounce and a half per man; some make much more than that sum, while those who are less fortunate fall much short of it. The actual number of persons working the placers will not vary much from ten thousand. The entire population now in the mining district is much greater than that number; but many are engaged in mercantile pursuits and in transporting goods and provisions, while others employ much of their time in 
"prospecting," or looking for newer and richer localities.

I also found that the reports which had reached me of hostilities between Americans and foreigners, in the mining districts, were greatly exaggerated, and that, with a few individual exceptions, every thing had remained quiet and orderly. In some of the northern placers a party of Americans and Europeans, urged on by political aspirants, who seem willing to eudanger the peace and tranquillity of the country, in order to promote their own personal interest, have assumed the authority to order all Mexicans and South Americans from that part of the territory. Their orders were quietly submitted to by the foreigners, a portion of whom removed to the mines further south, where the American population manifested a very decided disposition to afford them protection should they be further molested. The more intelligent and thinking portion of Americans regard this measure as illegal and injudicious, and will discountenance any repetition of movements so well calculated to disturb the public tranquillity, and to create bitter and exasperated feelings, where it is evidently our policy to cultivate those of the most friendly character. Some of the English, Irish, and German emigrants, in the northern placers, assisted in this movement against the Mexicans, Peruvians, and Chilians, and probably exerted themselves much more than any of our own citizens to create a prejudice and excitement against the Spanish race. They were probably actuated by pecuniary interest. The great influx of people from the southern portion of this continent was diminishing the price of labor in the towns near the northern rivers, and the large number of pack animals brought from Lower Califor- 
nia and Sonora was producing a corresponding reduction in the expenses of transportation.

For example, the price of a pack mule in some parts of the mining districts a few months ago was about $\$ 500$, whereas they can now be purchased for less than $\$ 150$. The cost of transportation from the principal landing on the San Joaquin River to the Sonoranian camp was $\$ 75$ per hundred, whereas at the present time it is only about $\$ 7$.

This has rednced the prices of provisions in the placers one and two hundred per cent. Some of the merchants who had large stocks of goods in the mines, and those who were engaged in transportation at the prices formerly paid, have suffered by the change, and it is natural that they should feel incensed against that class of foreigners who have contributed most to effect it.

But it is thought by others that the great majority of the laborers and consumers in the mining districts have been benefited by this change, and that it would be injurious to the prosperity of the country to restore things to their former state by the expulsion and prohibition of foreigners from the mines.

Americans, by their superior intelligence and shrewdness in business, generally contrive to turn to their own benefit the earnings of the Mexicans, Chilians, and Peruvians in this country, and any measure of exclusiveness which is calculated to diminish the productive labor of California would be of excechingly doubtful policy.

When applied to by the different parties for my opinion on the question of expelling foreigners, I have uniformly told them that no persons, native Americans or foreigners, have any legal right to dig gold in the 
public lands; but that, until the gorernment of the United States should act in the matter, they would not be molested in their pursuits; that I could not countenance any class of men in their attempts to monopolize the working of the mines, and that all questions touching the temporary right of individuals to work in particular localities, of which they were in actual possession, should be left to the decision of the local judicial authorities.

I cannot close my remarks on this subject without again calling the attention of government to the importance of establishing a mint in California at the earliest moment.

This measure is called for by every consideration of natural policy and of justice to the mercantile mining population of California.

General Kearny, during his administration of affairs in this country, appointed, by virtue of his authority as governor of California, two sub-Indian agents, who have ever since been continued in office, and their serrices found of great utility in preserving harmony among the wild tribes, and in regulating their intercourse with the whites.

They have been paid from the "civil fund" very moderate salaries, which will be continued until arrivals of agents regularly appointed by the general gorernment. Notwithstanding every effort on the part of those agents and of the officers of the army here, it has not been possible at all times to prevent agcression on the part of the whites, or to restrain the Indians from arenging these injuries in their own way.

In the month of April last, the agent in the Sacramento valley reported that a body of Oregonians and 
mountaineers had committed most horrible barbarities on the defenceless Indıans in that vicinity.

Those cruel and inhuman proceedings, added, perhaps, to the execution of a number of chiefs some year and a half since by a military force sent into the San Joaquin valley by my predecessor, (the facts of which were reported to Washington at the time, ) have necessarily produced a hostile feeling on the part of the natives, and several small parties of whites, who, in their pursuit of gold, ventured too far into the Indian country, have been killed.

My correspondence with the Indian agents and military officers established in the Sacramento and San Joaquin valleys will inform you of the measures taken to prevent a repetition of these difficulties.

I would respectfully recommend that at least three sub-Indian agents be appointed for this country, and stationed in the valleys of the Sacramento and San Joaquin.

These agents should receive ample pay in order to enable them to defray the expenses of living in that part of the country, and should be men of the highest moral character; for otherwise they would not resist the temptation to engage in illicit trade with the natives, or to employ them for the individual benefit of the agents in washing for gold.

The election called by me for the 1st instant was held on that day, and has been attended with the most happy results.

Every district has elected its local officers, and appointed delegates to meet in general convention at this place on the 1st proximo, to form a State Constitution or plan of territorial government, which will be submitted to the people for their ratification, and 
transmitted to Washington for the action of Congress.

Most of the local and judicial officers named in my proclamation of the $3 d$ of June, have already entered upon their duties, and the interest which was taken by the people in every part of the country in this election, and the zeal manifested by those elected and appointed to office, afford strong hopes that the existing gavernment will be able to preserve order and secure the administration of justice until a new ono shall be put into regular and successful operation.

In my former despatch I mentioned that the civil officers of the existing government would be paid their regular salaries from the "civil funds," which had been formed, under the direction of the governor of California, mainly out of the proceeds of the temporary custom-houses established by my predecessors on this coast.

It will also be necessary to use a portion of this fund in the immediate construction of jails for the security of civil prisoners.

The want of such jails has already led to the most serious inconveniencies; prisoners have so frequently effecterl their escape, that, on several occasions, the people hare risen in masses and executed criminals immediately after trial, and without waiting for the due fulfilment of all the requisitions of the laws.

In many eases it has been found necessary to confine ciril prisoners on board resscls of war, and in the guard-houses of the garrison; but in towns, at a distance from the coast and the military posts, the diffculty of retaining prisoners in custoly has led, in some instances, to immediate and summary executions.

This evil calls for an immediate remedy, which will 
be afforded, so far as the means at my disposal will admit.

I beg leave, in this place, to add a few remarks on the use which has been, and will continue to be, made of this "civil fund."

In the instructions from Washington to General Kearny, in 1846, for his guidance in California, the establishment of port regulations on this coast was assigned to the commander of the Pacific squadron, while it was said "the appointment of temporary collectors at the several ports appertains to the civil governor of the province."

It was also directed that the duties at the customhouses be used for the support of the necessary officers of the civil government. This division of duties, and this disposition of the proceeds of the customs were continued during the whole war.

On the receipt of the Treasury Department regulations respecting the collection of military contributions in Mexico, officers of the army and nary were made collectors at some of the ports, but at others the civil collectors appointed by the Gorernor of California were retained.

At the close of the war, Governor Mason, for reasons already communicated, determined to continue the collection of revenue in the country, on the authority which had previously been given to him, until Congress should act in the matter, or orders to the contrary be received from Washington. He, t'ierefore, as governor of California, again appointed ciril collectors in the ports where military officers had temporarily performed those duties, and collected the customs on all foreign goods, in accordance with the provisions of the tariff of 1846 , while the commander 
of the Pacific squadron continued the direction of all matters relating to port regulations. A double necessity impelled the governor to this course. The country was in pressing need of these foreign goods, and Congress had established no port of entry on this coast. The want of a more complete organization of the existing civil government was daily increasing, and, as Congress had made no provisions for supporting a government in this country, it was absolutely necessary to create a fund for that purpose from the duties collected on these foreign goods. It is true that there were no laws authorizing the collection of these duties; but at the same time the laws forbade the landing of the goods till the duties were paid. Governor Mason, therefore, had no alternative but to pursue the course which he adopted. He immediately communicated to Washington his action in the case; and as the receipt of his despatch was acknowledged without any dissent being expressed, it must be presumed that his course met the approbation of the government. When I assumed command in this country as civil governor, I was directed to receire these communications and instructions from Governor Mason, for my guidance in the administration of the civil affairs of this Territory. I have accordingly continued the collection of the revenue, and added the proceculs to the "civil fund," using that fund for the necessary expenses of the ciril gorernment. The expenses of employing civil officers in this country are very great; and as I hare no authority to liny taxes, this fund forms my only means of carrying on the government. The necessity of employing these officers, and of paying them the full salaries authorized by law under the existing state of affairs, is too ob38 
vious to require comment. I have pledged myself to pay these salaries from the "civil fund," unless forbidden to do so by direct orders from Washington; and that pledge will be fulfilled. This "civil fund" was commenced in the early part of 1847 , and has been formed and used in the manner pointed out in the early instructions to the governor of the Territory. This money has been collected and disbursed by the "Governor of California" and by those appointed by him in virtue of his office. $\mathrm{He}$ is, therefore, the person responsible for this money, both to the government and to the parties from whom it is collected, and it can be expended only on his orders. None of the military departments of the army, nor any army officer simply in virtue of his commission, can have any control, direct or indirect, over it. It is true that some of this money has, from time to time, as the wants of the service required, been transferred to the different military departments; but this transfer was in the form of a loan, and the money so transferred will be returned to the "civil fund" as soon as arrangements can be made for that purpose. The increased expenditures for the support of the existing government will soon render the restoration absolutely necessary; especially as the transfer of the customhouses to the regular collectors appointed by the general government, will now cut off all further means of supplying the civil treasury. These collectors have not yet arrived, but are daily expected.

Very respectfully, your obedient servant, BENNET RILEY,

Brevet Brig. Gen. U. S. Army, and Governor of California.

Major-General R. JoNEs,

Adjutant-General of the Army, Washington, D.C. 
The fullowing official despatch of General Tersifor F. Smith, contains an opinion of the position of San Francisco totally different from that of the numerous California tourists. It is a raluable opinion, nevertheless, and led to the selection of the town of Benicia, on the Straits of Karquinez, as a military and naval station.

\section{Headquarters Third Division,} San Francisco, April 5, 1849.

Generat :- Since my last communication no troops have arrived to change the strength of the force here; but the steam transport Edith arrived on the 21st of March, and reports that the transports Iowa and Massachusetts, the former having General Riley with a part of the $2 d$ infantry, and the latter having the command of artillery for Oregon on board, left Valparaiso about the 8th of February. The former is expected here every day, and the Edith is held in readiness to convey the troops south to the position they are to occupy.

There will be great difficulty in establishing and maintaining a post at the mouth of the Gila, until more knowledge is acquired of the navigation of the head of the gulf of California and the lower part of the Colorado. Transportation by land from San Diego is impossible for large quantities of stores.

In the gulf, the winds blow in the winter almost invariably from the northward; and in the summer, when they come occasionally from southward, it is in violent gales, with severe squalls and thunder, rendering it very dangerous to be in the gulf then. In other words, it is always difficult to 
run up the gulf, but almost always easy to run south. These circumstances render the employment of steam vessels very advantageous. If the navigation of the gulf permits the Edith to be used, she will answer, having both sails and steam. If she draws too much water, others of lighter draught could be procured. I mention this now, as the boundary commission will commence their labors on this end of the line, and will be on the Gila next season. I should have observed that the Colorado is supposed to be navigable only for boats drawing three or four feet.

I see no reason for posting troops on any other point out of reach of the ports on the Pacific. The Indians in the interior do not make it necessary, and it would be useless to place them near the mines to maintain order there. Nothing but the establishment of a regular civil government, to be carried on by those most interested in the existence of good order, will answer that end.

Such detachments as go to the southern part of the Territory will accordingly be placed, as heretofore mentioned, in healthy and convenient positions, and those on this bay at such points as will combine good climate, convenience of supply, and facility of movement. I propose, when such a point is found, to have removed all the public stores there, both from this place and Monterey, leaving the heavy ordnance and stores.

The town of San Francisco is no way fitted for military or commercial purposes; there is no harbor, a bad landing-place, bad water, no supplies of provisions, an inclement climate, and it is cut off from the rest of the country, except by a long circuit around the southern extremity of the bay. In time 
of war, enemies' troops could be landed for many miles south of the entrance of the bay on the sea beach, and thus cut it off by a short line across the peninsula on which it stands. There are points on the bay, more inland, having good harbors and landings, good water, and open to the whole country in rear, and accessible without difficulty to ships of the largest class. One of these should be the point at which the future depots should be established; and I propose to go to-morrow in the Edith, in company with Commodore Jones and other officers of the army and navy, to examine the straits of Karquinez, said to combine most advantages. I hope to return and report the result of our examination before the next mail boat leaves, (on Monday, 9th,) but at any rate by the succeeding boat, a few days afterwards.

I hope that in fixing the port of entry, capital, or other public places, the law will leave to the President the selection; otherwise, private interests already involved in speculation here, will, by misrepresentation, lead to a very bad choice.

If Congress has not provided by law for the government of this Territory, or its admirsion as a State, I would be very glad that the government would officially promulgate its views as to the civil authority now exercised here. Some important questions of law, involving both life and property, are now depending; and judges and jurors, without experience in these difficult questions, are called upon to act under great responsibility.

It appears to be the opinion of merchants in many of the ports of the Pacific-and they allege in support of it the advice of some of our consuls-that in virtue of the circular of the Secretary of the Treasury 
of October 30, as the Treasury Department could not collect duties on imports in California, their goods, though dutiable, could be imported without paying duty. I have held that this was not the construction proper to be given to the circular, but only that the law had not provided the means of collecting duties here, that law being still in force which prohibits certain goods being introduced into the United States, unless they pay duties as prescribed; that consequently no dutiable goods can be landed in California unless they shall have paid their duties elsewhere-the effect of which would be, that they could not be admitted at all from foreign ports.

Under the circumstances, which showed a very hard case, I thought it proper that the parties should be allowed to deposit the amount of duties and land the goods; but, lest this should be construed as giving them a right for the future, and as the president may think proper to put an end to this indulgence, I have addressed a circular to all our consuls on these seas, warning them of this possibility-a copy of which is inclosed.

I was directed, when coming here, by the Secretary of War, to do all I could to facilitate the arrival of the civil officers of government in Oregon, as the public service required their presence there. The steamer in which we came here could go no farther north, and there was no possible way of those gentlemen getting there, except on a small vessel about sailing, on which there were no accommodations.

Commodore Jones kindly sent carpenters from the fleet to put up some berths, and on General Adair's (the collector's) representation, that no bedding could be procured, I directed the quartermaster to issue him 
the necessary number of blankets for the royage, and take his receipt for them. I respectfully ask that this may be approved, and the amount charged to General Adair. The quartermaster could not tell hin the price of the blankets when he took them.

As the rainy season has ended, people are again repairing to the mines. New discoveries farther south are said to have been made; and it is now pretty certain that the whole slope of the Sierra Nevada, comprised within the head waters of the San Joaquin to the south and those of the Sacramento to the north, contains gold. These two rivers, forming, as it were, a bracket, join to cnter the bay of San Francisco; and their tributaries from the east, in their beds, expose the deposits of gold as they descend from the mountains. It is on the banks and branches of these streams that adventurers are now at work; but some excavations elsewhere, to a depth equal to that worn by the creeks, have disclosed quantities similar to those most gencrally found. There appears to be a line parallel to the summit of the main ridge, and some distance down the slope, at which the product of gold is at its maximum; but whether this be from the quantity deposited, or from the different position as relates to the surface, or from the difficulty of working it, I have not the means of knowing.

The gold is found in small particles: the largest I have seen, but such are rare, weighs seventy-one ounces troy. The appearance invariably is as though it had been spurted up when melted through crevices and fissures in drops, which have often the form of the leares and gravel on which they have fallen. I speak of this as an appearance, not as a theory or hypothesis. The extent ascertained within which gold is thus found is 
at least four hundred miles long by forty wide; in almost every part of which, where the surface is depressed by the beds of rivers, gold has been obtained without digging more than ten feet below the surface, and very seldom that much.

It is impossible to furnish any grounds for estimating the number of people engaged in mining, or the amount they have produced. Persons engaged in trading with the miners say they amount to about ten thousand, but I cannot say with what reason. They can better judge of the amount produced, which the lowest estimate places at $\$ 4,000,000$. More than three thousand persons have been added to the miners up to this time,-chiefly from Mexico and South America.

When the mines were first discovered, all the ports of South America on the Pacific, and of the Sandwich islands, sent the merchandise collected and stored there to be sold here. They realized enormous profits, before any competition from our eastern States could meet them; and these goods were generally owned by European houses, who thus became possessed of the first fruits of the mines, which were shipped to $\mathrm{Eu}$ rope on their account; and it is thus that so little gold has reached the United States.

When the merchandise now on its way from our Atlantic States arrives, and is sold, the current will set that way; but the profits will be much diminished by competition, and still more by the enormous expenses here for labor, storage, \&c. These are almost incredible; the ordinary wages for the poorest laborer is $\$ 6$ per day; many receive $\$ 10$.

The extent and richness of the gold region have not been exaggerated; and the exorbitant prices paid 
for labor, rent, and subsistence, have hardly been fully set forth. But all the estimates of the amount actually produced are but mere suppositions, which may surpass or may fall short of the truth.

I have already directed that the men to whom their commanding officers may give short leaves of absence may be employed by the quartermasters at the usual rates here. This will be an encouragement to the men and an advantage to the public service, as labor is hard to get. But I doubt the propriety of yielding to the current of gold-seeking, and allowing large bodies of the men to go to the mines. It may be permitted to reward good conduct, as any other indulgence is; but to make it general, would be either to acknowledge the right of the men to modify their obligations as they please, or to confess our inability to enforce their fulfilment. For the sake of principle and preciseness, it would be better to adhere to what is right now, though the effect here in this particular instance would be the desertion of the men.

I am, with respect, your obedient servant, PERSIFOR F. SMITH,

Brevet Major-General, commanding 3d Division, Brigadier-General R. Jones,

Adjutant-General. 


\section{ApPENDIX F.}

The following despatch contains instructions to General Kearny concerning the conquest of California, contained in a despatch from the Secretary of War, marked confidential. But a portion of these instructions were carried out, in consequence of the anticipation of the conquest by Commodore Stockton and Colonel Fremont.

[Confidential.]

\section{War Department, \\ Washington, June 3, 1846.}

SIR: I herewith send you a copy of my letter to the governor of Missouri for an additional force of one thousand mounted men.

The object of thus adding to the force under your command is not, as you will perceive, fully set forth in that letter, for the reason that it is deemed prudent that it should not, at this time, become a matter of public notoriety; but to you it is proper and necessary that it should be stated.

It has been decided by the President to be of the greatest importance in the pending war with Mexico to take the earliest possession of Upper California. An expedition with that view is hereby ordered, and you are designated to command it. To enable you to be in sufficient force to conduct it successfully, this additional force of a thousand mounted men has bcen provided, to follow you in the direction of Santa Fe, to be under your orders or the officer you may leave in command at Santa Fe.

It cannot be determined how far this additional force will be behind that designed for the Santa Fe 
expedition, but it will not probably be more than a few weeks. When you arrive at Santa Fe with the force already called, and shall have taken possession of it, you may find yourselves in a condition to garrison it with a small part of your command (as the additional force will soon be at that place), and with the remainder press forward to California. In that case you will make such arrangements as to being followed by the reinforcement before mentioned, as in your judgment may be deemed safe and prudent. I need not say to you that in case you conquer Santa Fe, (and with it will be included the department or state of New Mexico), it will be important to provide for retaining safe possession of it. Should you deem it prudent to have still more troops for the accomplishment of the objects herein designated, you will lose no time in communicating your opinion on that point, and all others connected with the enterprise, to this department. Indeed, you are hereby authorizer to make a direct requisition for it upon the gorernor of Missouri.

It is known that a large body of Mormon emigrants are en route to California for the purpose of settling in that country. You are desired to use all proper means to have a good understanding with them, to the end that the United States may have their cooperation in taking possession of and holding that country. It has been sugrested here that many of these Mormons would willingly enter into the service of the United States, and aid us in our expedition against California. You are hereby authorized to muster into service such as can be induced to volunteer; not, however, to a number exceeding one-third of your entire force. Should they enter the service 
they will be paid as other volunteers, and you can allow them to designate, so far as it can be properly done, the persons to act as officers thereof. It is understood that a considerable number of American citizens are now settled on the Sacramento River, near Sutter's establishment, called "Nueva IIelvetia," who are well disposed towards the United States. Should you, on your arrival in the country, fund this to be the true state of things there, you are authorized to organize and receive into the service of the United States such portion of these citizens as you may think useful to aid you to hold the possession of the country. You will in that case allow them, so far as you shall judge proper, to select their own offcers. A large discretionary power is invested in you in regard to these matters, as well as to all others, in relation to the expeditions confided to your command.

The choice of routes by which you will enter California will be left to your better knowledge and ampler means of getting accurate information. We are assured that a southern route (called the caravan route, by which the wild horses are brought from that country into New Mexico) is practicable, and it is suggested as not improbable that it can be passed over in the winter months, or at least late in autumn. It is hoped that this information may prove to be correct.

In regaril to the routes, the practicability of procuring needful supplies for men and animals, and transporting baggage, is a point to be well considered. Should the President be disappointed in his cherished hope that you will be able to reach the interior of Tpper California before winter, you are then desired 
to make the best arrangement you can for sustaining your forces during the winter, and for an carly movement in the spring. Though it is rery lesirable that the expedition should reach California this season, (and the President does not doubt you will make every possible effort to accomplish this object), yet if, in your judgment, it cannot be undertaken with a reasonable prospect of success, you will defer it, as above suggested, until spring. You are left unembarrassed by any specific directions in this matter.

It is expected that the naval forces of the United States which are now, or will soon be in the Pacific, will be in possession of all the towns on the seacoast, and will co-operate with you in the conquest of California. Arms, ordnance, munitions of war, and provisions to be used in that country, will le sent by sca to our squadron in the Pacific for the use of the land forces.

Should you conquer and take possession of New Mexico and Upper C'alifornia, or considerable places in either, you will establish temporary civil governments therein-abolishing all arbitrary restrictions that may exist, so far as it may be done with safety. In performing this duty, it would be wise and prulent to continue in their cmployment all such of the existingr officers as are known to be firiendly to the United States, and will take the oath of allegiance to them. The duties at the custom-house ought at once to be reduced to such a rate as may bc barely sufficient to maintain the necessary officers, without yelding any revenue to the gorermment. You may assure the people of those prorinees, that it is the wish and design of the Cnited States to provide for tbem a free 
government with the least possible delay, similar to that which exists in our territories. They will then be called on to exereise the rights of freemen in electing their own representatives to the territorial legislature. It is foreseen that what relates to the civil government will be a difficult and unpleasant part of your duty, and much must necessarily be left to your own discretion. In your whole conduct you will act in such a manner as best to conciliate the inhabitants and render them friendly to the United States.

It is desirable that the usual trade between the citizens of the United States and the Mexican provinces should be continued, as far as practicable, under the changed condition of things between the two countries. In consequence of extending your expedition into California, it may be proper that you should increase your supply for goods to be distributed as presents to the Indians. The United States superintendent of Indian affairs at St. Louis will aid you in procuring these goods. You will be furnished with a proclamation in the Spanish language, to be issued by you and circulated among the Mexican people on your entering into or approaching their country. You will use your utmost endeavors to have the pledges and promises therein contained carried out to the utmost extent.

I am directed by the President to say that the rank of brevet brigadier-general will be conferred on you as soon as you commence your morement towards Californial, and sent round to jou by sea or orer the country, or to the care of the commandant of our squadrun in the Pacific. In that way cannon, arms, 
ammunition, and supplies for the land forecs rill bo sent to you.

Very respectfully, your obedient servant,

W. L. MARCY,

Colonel S. W. KEARnY.

Secretary of War.

Fort Leavenworth, Missouri.

\section{Appendix $G$.}

The particulars of the conquest of Upper California, as well as the suppression of the insurrections, we have already giren in substance as they are in the despatches of General Kicarny and Commodore Stockton. But we have said nothing of the transactions in the Peninsula, as that afterwards was surrendered to Mexico. All that is interesting in the conquest of Lower California, will be found in the following despatches from the commander of the New York regiment of roluntecrs, which with a number of marines were the only troops employed in that quarter. We premise, that, after the Lnited States marines had taken San José, the natives rose, and they were reduced to the necessity of taking refuge in an old fort, or cuartel, in the town.

\section{Barracks, Lower Caltforita, San Jose, February 20, 1848.}

SIr: I continue my report from the $22 \mathrm{~d}$ ultimo, from which time my force consisted of twenty-seren marines and fifteen seamen, of whom five were on the sick report, besides some twenty voluntecrs, Californians, who at least served to swell the numbers. From 
that date the enemy were continually in sight of us, intercepting all communication with the interior, and driving off all the cattle from the neighborhood. A party of our men who went out to endeavor to obtain cattle, were driven in and narrowly escaped being cut off. We succeeded in obtaining a few cows, however, which were very necessary to us in the reduced state of our provisions, as, in addition to our garrison, we were obliged, in humanity, to sustain some fifty women and children of the poor, who sought our protection in the greatest distress. I found it necessary, as soon as our fresh b.eef was consumed, to put all hands on half allowance of salt provisions. We had no bread. On the 4 th of February, the enemy closed around us more, and commenced firing upon all who showed themselves at our port-holes, or above the parapets. On the morning of the 6th the enemy appeared to be a little scattered, a considerable force being seen riding about some distance from the town, and at the same time a strong party of them posted at the lower end of the strect were keeping up an annoying fire upon us. I judged this a farorable opportunity to make a sortic upon them, and taking twenty-five men with me, closed with them and dislodged them, driving them into the hills without the loss of a man on our part, and returned to the cuartel. On the morning of the 7 th it was reported to me that the enemy had broken into the houses on the main street, and there was some property exposed which might be sccured. I took a party of men and went down and brought up a number of articles belonging to the Californians, who were in the cuartel; some distant firing took place, but no injury was sustained. On the same day, hearing there were some stores of 
rice and tobacco in a house some three hundred yards down the main street, I determined upon an effort to obtain them, and sallied out with thirty men: these were immediately fired upon from sereral different quarters, and some fighting ensued, resulting in the death of one of my roluntecrs-shot through the heart. We charged down the end of the street, and drore the enemy to the corer of a cornfield at the outside of the town, where they were considerably reinforced, and recommenced a hot fire; but we were enabled to saro a part of the articles which we were in search of, though we found that the enemy had anticipated us in this object, having forced the building from the rear. On the afternoon of the following day, Ritchie's schooner, having provisions for us from La Paz, came in sight and anchored, but a canoo which was enticed toward the shore by a white fag displayed by the eneny, was fired upon, and the schooner immediately got under way.

On the 10th the enemy had entire possession of the town: they had perforated with port-holes all the adjacent houses and walls, occupying the church, and, hoisting their flag on Galindo's house, ninety yards distant, held a high and commanding position, which exposet our back yard and the kitchen to a raking fire, which from this time forth was almost incessant from all quarters upon us, the least exposure of person creating a target for fifty simultaneous shots. The enemy appeared to hare some excellent rifles, among other arms; and some of them proved themselves tolerably sharp shooters, sending their balls continually through. our port-holes. On the 11th the fire was warm, but on our part it was rarely that we could get a sight of them. In the afternoon of this day we had to lament 
the death of Passed Midshipman MeLanahan, attached to the United States ship Cyane; a ball striking him in the right side of the neck, a little below the thyroid cartilage, lodged in the left shoulder. He died in about two hours. He was a young officer of great promise, energetic, of much forethought for his age, and brave to temerity: All lamented his untimely fate, and all bear willing testimony to his worth.

On the morning of the 12th, at daylight, we discorered that the enemy had thrown up a breastwork upon the sand, about one hundred and fifty yards to the north-east of the cuartel, and entirely commanding our watering place. We fred several round shot at it, with little effect. We succeeded in getting in being in strong force, and kept a close watch upon us. Their force was orer thrce hundred, speaking within bounds. I immediately commeneed digging a well in the rear of Mott's house, which is the lowest ground. I found that we had to go through rock, and judged we should have to dig about twenty fect. I thought it imprudent to blast, as the encmy, suspecting our intention, would throw every obstacle in our way. The men worked cheerfully on this and the succeeding day against all difficulties. Our situation was becoming now an imminently critical one, having with the greatest economy but four days' water. On the 14 th we continued digging for water. We found that the cnemy had thrown up a second bicastwork more to the westward, giring them a cross-fire upon our watering place: there was a continual fire kept up upon the cuartel during tise day. At three o'clock, 30 minutes P.M., a sail was reported in sight, which proved to be the United Ship Cyane. She anchored after sun- 
down. It was of course a joyful sight to us to see friendis so near; but I was apprehensive that they could render us but little assistance, the enemy being so rastly superior in numbers. The enemy continued their firing upon us during the night. On the 15th at day-light, we became aware that the Cyane was landing men. They soon commenced their arlvance, which for a few moments was opposed only by a scattering fire; then the enemy opened upon them in earnest. They had concentrated nearly their entire force near San Vincente. We saw the flash of musketry through all the hills above the village. There was the odds of three to one against our friends. Steadily they came on, giving back the enemy's fire as they advanced. There was still a party of the enemy occupying tho town, firing upon us. I took thirty men, and sallied out upon them, drove them from cover, killed one and wounded several of them, and marched out to join the Cyane's men, who, with Captain Dupont at their head, had now drawn quite near to us. There were small detached parties of the enemy still hovering about them, and firing at them, but the main body of the enemy had been broken, and retired to "Las Animas," distant two miles. The march of the Cyane's men to our relief, through an enemy so vastly their superior in numbers, well mounted and possessing every advantage in knowledge of the ground, was certainly an intrepid exploit, as creditably performed as it was skilfully and boldly planned, and reflects the greatest honor on all concerned. It resulted most fortunately for us in our harassed situation. They had but four wounded; this cannot be termed any thing but the most remarkably good luck, considering the severe fire that this heroic little band were ex- 
posed to. The loss of the enemy we have not nositirely ascertained: we hear of thirtecn killed, with certainty, and general report says thirty-fire; wounded not known. Of the total loss of the eneny in their attack upon the cuartel, I cannot speak with certainty; we have found several graves, and know of a number wounded, one of whom we have in the cuartel a prisoner. I suppose their total loss to be not far from fifteen killed, and many wounded; I am sure it could not be less than this. Our own total loss was thee killed and four slightly wounded. After the death of Passed Midshipman MeLanahan, there remained but one officer to my assistance, Passed Midshi man George A. Stevens, to whom, for his coolness and indefatigable zeal at a time when so much devolved upon him, I am most happy to accord the highest credit; and at the same time I must honorably mention the conduct of a rolunteer, Engene Gillespie, Esq., who, although suffering from illness, never deserted his post, and was with me in the sortie of the 7 th. The non-commissioned ufficers and men went through privation, unceasing watchfulness, and danger, without a murmur. I cannot exrress too highly my satisfaction in their conduct. Captain Dupont immediately upon his arrival here, becoming aware of our situation as regards provisions, took measures for our supply. The day after the battle of San Vincente he despatched a train, which brought us by hand (the enemy having driven off all the mules and horses) a quantity of stores and articles of which we stood most in need, among the rest, bread, and has since been unceasing in his exertions for our relief. I cannot too earnestly express the obligations which we are under 
for the prompt and cificient assistance which Captain Dupont, his officers, and crew have rendered us.

I am, sir, respectfully, your obedient servant, CHAS. HEYWOOD,

Lieutenant U. S. Nary, com'g., Sun Jose. Lieut. Col. Henrey S. Burton, U. S. Army, com'g. troops in Loner California. W. T. SHERMAN,

First Lieutenant 3d Artillery, A. A. A. General.

\section{H.}

United States Barracis, La Paz, California, April 13, 1848.

Sir: I have the honor to acknowledge the receipt of your letter of March 1, 1848, and to report the arrival of the army storeship "Isabella" at this place on the 22d of March, 1848, with Captain Naglee's company (D) New York volunteers, and one hundred and fourteen recruits for the detachment of New York volunteers stationed at this place.

The rescue of the prisoners of war on the 15th viltimo caused great excitement among the enemy, and tended very much to disorganize their forces, and the important arrival of the reinforcements to my command determined me to take the field as soon as possible; accordingly, I left this place on the morning of the 26 th instant with two hundred and serenteen officers and men; Lieutenant Halleck, United States engineers, acting clief of staff, and Passed Midshipman Duncan, United States nary, temporarily attached to the mounted portion of Captain Naglee's command. 
The afternoon of the $27 \mathrm{th}$, a party of fifteen men captured, in San Antonio, Pineda, the commander of the Mexican forces, with his secretary, Serrano.

The moming of the $29 \mathrm{th}$, liaving received information thet the enemy had concentrated their forces in Todos Santos, we pressed on with all speed, fearing they might evale us, by retreating torards Nagdalena Bay. The morning of the $30 \mathrm{th}$, about ten o'clock, having received accurate information respecting the enemy, Captain Naglee with forty-five mounted men was despatched to intercept the road leading from Todos Santos to Magdalena Bay, and, if practicable, to attack the enemy in the rear at the same time our main body made its attack in front.

The road leading from Todos Santos to La Paz, for some distance before reaching the first named place, passes through a dense growth of chaparral, (very farorable for an ambush), and in this the enemy made their arrangements to receive us. We left the road about fire miles from Todos Santos and marched along a ridge of high land on the north side of the river, having full view of the enemy's operations.

They then took possession of a commanding hill directly in our route, between three and four miles from Todos Santos, with their Indians in front. Companies $A$ and $B$, under the direction of Lieutenant Halleck, were deployed as skirmishers in such a manner as to expose the enemy to a cross-fire. The enemy opened their fire at long distance, but our force advanced steadily, reserring their fire until within good musket range, when it was delivered with great effect, and the enemy retreated rery rapidly, after a short but sharp engagement. At this time, Captain Naglee being near Todos Santos, and hearing the firing, 
attacked the encmy in rear, and after a serere action completed their dispersion. Our men and horses being too much fatigucd by their long march to pursue the scattered encmy, we marched on to Todos Santos.

The loss of the enemy in this engagement cannot be ascertained with any accuracy; we know of ten killed and eight wounded. Our loss was nothing; one man and the horse of Acting Lieutenant Scott were slightly wounded, the enemy, as usual, firing too high.

Our officers and men fully sustained the character they wnn on the 16th and 27th of Norember last.

My warmest thanks are due to Lieutenant Halleck, for his assistance as chicf of staff, and I present him particularly to the notice of the colonel commanding, for the able manner in which he led on the attack on the 30 th ultimo.

Captain Naglee also deserres particular notice for the energetic and successful manner in which he fulfilled his instructions.

On the 31st ultimo, Captain Naglee, with fifty mounted men of his company, was ordered to pursue the encrny in the direction of Magdalena Bay. He returned to La Paz on the 12th instant, having pursued the enemy rery closely, capturing five prisoners and some arms.

Lientenant Iralleck started for San José with a party of mounted men, consisting of one officer and twenty-fre non-commissioned oficers and prirates, on the Jth instant, for the purpose of communicating with Captain I upont, commanding Lnited States sioop-of-war Cyane. Ile returned here on the 11th instant, having captured ten prisoners on his march, and taken a number of arms. 
From him I learn that the naval force at San Jose have thirty odd prisoners, and among others "Mauricio Castro," the self-styled political chief of Lower California. Lieutenant Selden, with a party from the Cyane, made a most opportune march on Santiago, where he captured a number of the enemy who had fled from the field of Tolos Santos. Castro, who ccmmanded the enemy's forces in the action of the 30 th, was arrested near Maria Flores by the civil au:horities and delivered up to Lieutenant Selden.

During the stay of our main body at Todos Santos fourteen prisoners were captured; among them two sons of the reverend padre Gabriel Gonzales, officers of the Mexican forces.

We left Todos Santos on the 5 th instant, and arrired at this place on the 7 th. The result of this short campaign has been the complete defeat and dispersion of the enemy's forces.

We have captured their chief and six officers, and one hundred and three non-commissioned officers and privates; and other's are daily presenting themselves to the civil authorities in different parts of the country.

The captured arms have been giren to those rancheros known to be friendly to the interests of the United States, for their protection.

I am, sir, with much respect, your obedient servant, HENRY S. BURT'ON,

Lieutenant Crolonel New York Volunteers.

Lieutenant W. T. Sherman, Act. Ass. Adjt. Gen. Tenth Mil. Dep.

$$
\text { W. T. SHERMAN, }
$$

First Lieut. 3d Artillery A. A. A. General. 


\section{Appendix I.}

The following despatch from Governor Mason, gives an account of the state of affairs in Upper California, in October, 1847 :

\section{Headquarters Tente Military Department, Monterey, California, October 7, 1847.}

Sin: Ireturned from San Francisco resterday, and found here Mr. Toler, with despatches from Wrashington, the receipt of which I have the honor to acknowledge. I am also informed by Commodore Shubrick that the sloop-of-war Preble is reacly to sail for Panama, with Passed Midshipman Wilson as bearer of despatches for the United States. I therefore avail myself of the opportunity to send you my letter of the 18 th of September, with its sereral packages, and now have to communicate the result of my risit to San Francisco.

I found the town flourishing and prosperous, with a busy, inclustrious population of Americans, and refer you to the copies of my military correspondence for the steps alopted to give them a good town government. The Bay of San Francisco, you are well aware, is a spacious, elegant harbor, susceptible of the most perfect defence; but as jet nothing has been done towards fortifying it, or even placing any of the heary guns in positicn at the old fort. It is found almost impossible to get much work out of the rolunteers; and all that I can now expect of the two companies of Najor Ifardie's command will be to improve their quarters at the old presidio. This they are at present engaged upon, using lumber made at the horse sawmill, under direction of the assistant quartermaster, 
Captain Folsom. All this labor is done by the volunteers, so that the improvements will be made at very little expense to the government. The price of lumber at San Francisco is $\$ 50$ per M.; but Captain Folsom says that he has it sawed and delivered, by the labor of the volunteers and his own machinery, at about $\$ 16$. The mill is placed in the timber known as the Red Woods, near the mission of San Rafael, on the west and north sides of the bay, where any amount can be had. If the government design to erect permanent structures to any extent in this country, it would be advisable to scnd out a steam engine, with all the necessary frames and iron-work to adapt it to immediate use in connexion with the saw and grist mills now in possession of the quartermaster's department here. The site at present selceted by Captain Folsom is well adapted, as easy water communication is had with the San Joaquin and Sacramento Rivers as well as the parts of the country south of San Francisco.

At San Francisco I found all the powder, arms, accoutrements, and perishable ordnance property well stored in a building prepared for the purpose at the presidio barracks; but the guns, mortars, carriages, shot, and shells are in the town in the open air, protected by paint alone. The great difficulty of hauling such articles over the rugged hills between the town and presidio will prevent their being hauled to the latter place this season.

I did design to continue my tour of inspection to Sonoma and the Sacramento River, but was recalled by hearing of the arrival of the bearer of despatches at Monterey.

When on my way up to San Francisco, I was overtaken by Captain Brown, of the Mormon battalion, 
who had arrivel from Fort IIall, where he had left his detachment of the battalion, to come to California to report to me in person. Ile brought a muster-roll of his detachment, with a power of atturney from all its members to draw their pay; and as the battalion itself had been discharged on the 16th of July, Paymaster Rich paid to Captain Brown the money due the detachment up to that date, according to the rank they bore upon the muster-rolls upon which the battalion had been mustered out of service. Captain Brown started immediatcly for Fort Hall, at which place and in the ralley of Bear River he said the whole Mormon emigration intenderl to pass the winter. He reported that he had met Captain Hunt, late of the Mormon battalion, who was on his way to meet the emigrants and bring into the country this winter, if possible, a battalion according to the terms offered in my letter to him of the 16th of August, a copy of which you will find among the military correspondence of the department.

In my letter I offered Captain Hunt the command of the battalion with the rank of lieutenant-colonel, with an adjutant; but I find, by the orders lately received, that a battalion of four companies is only entitled to a major and acting adjutant. I will notify Captain Hunt of this change at as early a moment as I can communicate with him. I am pleased to find by the despatches that in this matter I have anticipated the wish of the department.

Last season there was a great scarcity of provisions on the coast of California; but when the stores are received that are now on their way, there will be an ample supply for the coming winter. The crops in this country have been very fine this season, and at 
present wheat is plenty and cheap at San Francisco. Beef is also plenty. Beans can be purchased at the sonthern ports, and sugar imported from the Sandwich Islauds; but for all other subsistence stores we are dependent upon the South American ports or those of the United States. I have directed Captain Marcy, acting commissary of subsistence at this post, to supply the chief of his department with the market price of all kinds of provisions, with such other facts as may enable his department to act with the proper economy. The want of good clothing for the regulars and rolunteers is alrearly felt in California ; and unless a supply has already been despatehed, many of the garrisons will be without shoes and proper clothing this winter. The price of such articles here is so exorbitant as to place them beyond the reach of the soldiers. The volunteer clothing brought by Sutler Haight has alrearly been disposed of to citizens and soldiers, and there are no means of his renewing the supply except by sending to the United States. Justice to the soldier demands that he either be comfortably clad by the government, or that it should be within his power to clothe himself on the allowance provided for that purpose by law.

I respectfully recommend, if it has not already been done, that a large supply of infantry undress winter clothing be sent immediately to this country, to be distributed, so as to enable each volunteer to purchase for his own immediate use at cost prices. No summer clothing is needed, as the climate is too severe, summer and winter. Such articles as good blankets, cloth overcoats, caps, jackets, overalls, stockings, and shoes, with stout shirts and drawers, are the only ones that will ever be needed here. 
General orders No. 10, of 1847 , promotes Lientenant Loeser, third artillery, and orders him to join his company. I regret that at this moment his services cannot be spared, and I am compelled to retain hin on duty with company $\mathrm{F}$, third artillery, because the absence of Captain Tompkins, the death of Lieutenant Minor, and Lieutenant Sherman being detached as acting assistant adjutant general, has reduced the number of officers of that company to but twoLieutenants Ord and Loeser. I trust that the two companics of regulars in this country will be kept with a full supply of officers, that an officer, upon being promoted, may be enabled to join the army in the field, and participate in the active operations to which he looks for distinction and experience.

Captain H. M. Naglee, seventh New York roluntecrs, with a strong detachment of his company, is now absent in pursuit of Indians in the valley of the San Joaquin. He has with him Lieutenant Burton's company of California volunteers, which is expected to return to Monterey before the end of this month; in which case I shall cause it to be mustered out of service, and discharged on the 31st day of October.

Again I have to report the death, by sickness, of an officer of my command-Lieutenant C. C. Anderson, seventh New York volunteers, who contracted a ferer when on duty at Fort Sacramento, and died in consequence at San Francisco on the 13th of September. He was buried with military honors by the troops at San Francisco, under direction of Major Hardie. This death reduces the number of officers in Captain Brackett's company, seventh regiment New York volunteers, to one captain and one second lieutenant.

Commodore Shubrick will sail for the west coast of 
Mexico from this harbor next week; and having made application to me, I have directed Lieutenant Halleck, of the engineer corps, to accompany him, and shall give Lieutenant Colonel Burton, in command at $\mathrm{La}$ Paz, Lower California, authority to accompany Commodore Shubrick, should the latter design an attack upon any point or points of the west coast of Mexico, with orders, of course, to resume his position at La $\mathrm{Paz}$ as soon as the object is accomplished for which his command is desired.

Note.-Colonel Burton will be directed to leave a sufficient number of men at $\mathrm{La} \mathrm{Paz}$ to keep the flag flying.

It afiords me much pleasure to assure the department that the most perfect harmony subsists between the members of the naval and land forces on this coast, and that the most friendly intercourse is kept up between the officers. I have had frequent occasion myself to ask assistance of Commodores Biddle and Shubrick, and my requests have been granted with promptness and politeness; and in return I have afforded them all the assistance in my power. Our consultations have been frequent and perfectly harmonious, resulting, I hope, in the advancement of the common cause of our country.

I have the honor to be, your most obedient servant, R. B. MASON,

Oolonel 1st Dragoons, Commanding.

To General R. Jones, Adiutant-General, Washington, D. C. 


\section{APPENDIX J.}

We have already given the substance of Governor Mason's despatch to the government, giving an account of the gold discovery and a visit to the placers. There is, therefore, no necessity for inserting that official document. The appearance in Upper California, in July 1848, of Don Pio Pico, the former governor of the territory, gave rise to serious apprehensions of another insurrection. The despatch of Col. Stephenson, the commander of the garrison at Los Angeles, to Colonel Mason, contains an account of the matter, together with a description of the ex-governor.

Headquarters Soutueria Mimitary District,

Los Angeles, Culifornia, July 20, 1848.

SIR: By the last mail I informed you of the arrival of Don Pio Pico in this district. I subsequently learned that he had passed through San Diego without presenting himself to Captain Shannon, or in any manner reporting his arrival. Immediately after his arrival, rumor's reached me of conversations had by him with his countrymen, in which he stated that he had returned with full powers to resume his gubernatorial functions, and that he had only to exhibit his credentials to you to have the civil government turned over to him. I found the people becoming very much excited, and some rather disposed to be imprudent. I sent for Jose Ant. Carrillo and some others in the town, who were giving currency to these reports, and informed them that I should hold them responsible for any imprudent or indiscreet act of their countrymen, and that, at the first appearance of any disrespect to the American authorities, I should arrest and confine them in the guard-house. This had the 
effect to check all excitement here; but as Don Pio removed up the country, the same excitement began to spread among the rancheros. In the mean time, his brother Andreas informed me that he, Don Pio, would come in and report to me in person in a few days, as soon as he had recovered from the fatigue of his journey. On Saturday, the 15th instant, he reached the ranch of an Englishman named Workman, some eighteen miles from here. This man has ever been hostile to the American cause and interest, and is just the man to advise Pico not to come in and report to me.

On Sunday and Monday I was advised that many Californians had risited Pico at Workman's, and that the same story had been told them of his having returned to resume his gubernatorial functions, \&c., and also that he should not report to me, but go direct to San Fernando, from whence he would communicate with you. The moment I became satisfied that he intended to adopt this course, I issued an order (copy inclosed) requiring him to report to me immediately in person. I sent my adjutant with a detachment of men to the ranch of Workman to deliver to Don Pio in person a copy of this order, with instructions to bring him in by force, in case he refused or even hesitated to obey. The adjutant returned here at twelve o'clock on Monday with information that the Don had left for San Fernando. I immediately despatched Lieutenant Davidson with a detachment of dragoons and a copy of the order, with instructions similar to those given Adjutant Bonnycastle. About five o'clock on Tuesday morning I received a visit from a gentleman named Reed, living at the mission of San Gabriel, who informed me that Don Pio Pico: 
had arrived at his house quite late in the evening of Monday, on his way to San Fernando. Reed inquired if he did not intend reporting to me in person; he answered in the negative; when Reed assured him, if he attempted to pass my post without reporting, I would cause him to be arrested, and that he was aware of my being displeased at his passing through San Diego rithout reporting to the commandant of that post. Don Pio Pico, upon receiving this information, became alarmed, and requested Reed to come in and see me, to say he intended no disrespect, and would come and report at any hour I would name. Reed is a highly respectable man, and has erer been friendly to the American cause; and I gave him a copy of the order I had issued in regard to Don Iio, requesting him to deliver it, and say to $\mathrm{Don} \mathrm{Pio}$, he could come in at any hour he chose, within trintyfour hours. Accordingly about eight P. M., the same evening, the ex-gorernor came in. Ife was unaccompanied even by a servant, evidently desiring it should not be known he was in town. I received him kirdly, told him I had no desire to treat him harshly, but that the Amcrican authorities must be respected, and if he had not come in I should certainly have arrested him. He informed me that lie left Guaynas on the 221 of May, crossed to Minlige, which he left for California on June third, and arrived at San Diego, July sixth. He says that when he left Guaynas nothing had been beard of the action of the Mexican Congress upon the treaty, but it was generally supposed it would be ratified. He says the Mexican government did not answer any of his communications; and the moment lie saw the armistice published in a newspuper, he determincd to return home, as he supposed he ooold 
return with credit, under the stipulations of the armistice. He brings with him no other authority for his return, and says he desires to live peaceably, and attend to his private affairs. He denies ever having said that he came back with powers to resume his gubernatorial functions, and that he rebuked such of his friends as he had seen for their last attempt at a revolution, and advises that they remain quiet and obey the laws, as no part of the people of the conquered Mexican territory have been treated as kindly as the Californians have been by the American authorities. He thanked me for my personal kindness to his family and countrymen in general, and said if I would permit him he would go to San Fernando, from whence he would answer that part of my order which required a written communication from him. I gave him permission to leave, and offered him an escort, which he thanked me for, but declined. Don Pio Pico is about fire feet seven inches high, corpulent, very dark, with strongly-marked African features; he is, no doubt, an amiable, kind hearted man, who has ever been the tool of knaves; he docs not appear to possess more intelligence than the rancheros generally do; he can sign his name, but I am informed he cannot write a connected letter; hence, as he informed me, he would be compelled to send for his former secretary before he could answer my order or communicate with you, which he advised me he intended doing. I have promised to take charge of and forward any communication he may choose to make you. He left town on Wednesday morning very early, as obscurely as he had entered it; and those who advised him to assume the bombastic tone be did upon his first arrival, have done him irreparable injury, 
for he is now ridiculed by many who before entertained a high respect for him.

I have the honor to be, very respectfully, your obedient servant,

\section{J. D. STEVENSON,}

Coloncl 1st New York Regiment, commanding S. M. District.

Colonel R. B. Mason,

1st U. Dragoons, Governor of California.

P. S.-Since writing the above, I have received the inclosed note from Don Pio Pico, inclosing a communication to your excellency. In the note of Don Pio to me, you will perceire that he is no sooner arrived at San Fernando than he claims to have returned to California as its Mexican governor, to carry out tho provisions of the armistice. I shall not answer his note until I have heard from you; but I shall keep an eje on him, and if I find he is preaching sedition, I will bring him in here at short notice.

\section{W. T. SHERMAN,}

$$
\begin{aligned}
& \text { J. D. STEVENSON, } \\
& \text { "Colonel, commanding, }
\end{aligned}
$$

First Lieutenant 3d Aritlery, A. A. A. General.

\section{Appendix $K$.}

On the 13th of April, 1819, Colonel Mason at his own request, was relievel from the post of Governor of California, and Brigadier-General Riley took his place. The despatch of that offieer, datel 30 th of June, following his assuming the dutics of his post, is important, as containing an account of the state of feeling in California, upon the subject of the laws at 
that time in force, and the difficulties with various assemblies elected in the northern part of the territories.

\section{Executive Departuejt of Califoria, Monterey, June 30, 1849.}

Gexeral : I have the honor to transmit herewith copies of all civil correspondence and papers since the 13th of April last, at which time I relieved Colonel Mason from his duties as Governor of California.

It was (with the advice of Colonel Mason) my intention, on assuming the direction of civil affairs in this country, to complete the organization of the existing gorernment; at the same time to call a conrention for forming a State Constitution, or plan of territorial government, to be submitted to Congress for its approval. But on further consultation it was deemed best to postpone all action on this subject, until I could ascertain what had been done in Congress. On the first instant I received reliable information by the stcamer "Edith" that that body had adjourned without organizing any territorial government for this country; and accordingly, on the $3 d$ instant I issued my proclamation to the people of California, defining what was understood to be the legal position of affairs here, and pointing out the course it was deemed advisable to pursue in order to procure a new political organization better adapted to the character and present condition of the country. The course indicated in my proclamation will be adopted by the people, almost unanimously, and there is now little or no doubt that the convention will meet on the first of September next and form a State Constitution, to be submitted to Congress in the early part of the coming session. 
A few prefer a territorial organization, but I think a majority will be in favor of a State government, so as to avoid all further difficulties respecting the question of slavery. This question will probably be submitted, together with the Constitution, to a direct rote of the people, in order that the wishes of the people of California may be clearly and fully expressed. Of course, the Constitution or plan of territorial government formed by this convention can have no legal force till approved by Congress.

On the receipt of the treaty of peace with Mexico, doubt was entertained by a portion of the people here respecting what constituted the legal government and laws of the country. A few contended that all government and all laws in California were at an end, and that therefore the people, in their sovereign eapacity, might make such government and laws as they should deem proper. Accordingly, in two of the northern districts, local legislative assemblies were organized, and laws enacted for the government of the people of these districts. The members of the Sonoma assembly, however, soon became convineed of their error, and that body was dissolved. But in San Franciseo the assembly continued its sessions, making laws, creating and flling offices, imposing and collecting taxes, without the authority and in violation of law, and finally went so far as to abolish the office of alcalde, whose records and papers were seized and forcibly refnoved from his custody. On receiving official information of these facts, I issued my proclamation of the 4th instant. Since then I have made a. personal visit to San Francisco, and find that the more respectable members of the so-called district assembly are convinced of the impropriety of the 
course pursued by that body, and in a very short time I think all the difficulties will be amicably arranged. These difficulties arose in part from a misapprehension as to what constituted the legal government of the country, and in part from the unpopularity of the first alcalde of that district, against whom serious charges had been made. Unfortunately, there was at the time no legal tribunal for investigating these charges; and, there being no other magistrate in that district, I could not, with propriety, remove him from office. A new election, however, will soon be held to supply his place; and on the organization of the "superior court," the charges against him can be properly investigated.

The publication of a portion of the instructions received from Washington respecting the government of this country, and the disposition manifested by the authorities here to enforce the existing laws, have done much to remove the erroneous opinions which were for a time entertained by a portion of the people of California. The civil government of this country has been, and will continue to be, administered on the principle laid down by the Supreme Court of the United States, viz: on the transfer of the ceded territory, it has never been held that the relations of the inhabitants with each other undergo any change. Their relations with their former sovereign are dissolved, and new relations are created between them and the government which has acquired their territory. The mere act which transfers their country transfers the allegiance of those who remain in it; and the law which may be denominated political is necessarily changed, although that which regulates the intercourse and general conduct of individuals remains in force 
until altered by the newly-created power of the State.

The treaty is the law of the land, and admits the inhabitants of [California] to the enjoyment of the privileges, rights, and immunities of citizens of the United States. It is unnecessary to inquire whether this is not their condition, independent of stipulation. They do not, however, participate in political power; they do not share in the government till [California] shall become a State. In the mean time, [California] continues to be a territory of the United States, governed by virtue of that clause of the constitution which empowers Congress to make all needful rules and regulations respecting the territory and other property belonging to the United States.

When we take into consideration the great mass of Iloating population of the Cnited States and of other countries-people of all nations, kindreds and tongues -which has been suddenly thrown into this country, it must be acknowledged that every thing has, thus far, remained remarkably quiet, and that the amount of crime has been much less than might, under the circumstances, have reasonably been expected. It is to be feared, however, that during the coming winter, Then large numbers of the miners collect in the towns, public order may be occasionally disturbed. But it is believed that in the mean time a more complete organization of the existing government will be effected, so as to enable the authorities to enforce the laws with greater regularity and efficiency.

Rumors have reached me that there is no very amicable feeling existing between the Americans and foreigners in the gold regions, and that the former are disposed to forcibly expel the latter from the placer 
districts. I shall soon visit the valleys of the Sacramento and San Joaquin, and hope to be able to report upon the true state of affairs there by the August steamer. As Congress has declined passing any laws restricting the working of the placers, I shall not deem myself authorized to interfere in this matter, any further than may be necessary to preserve the public tranquillity. Indeed there is much reason to believe that Congress has pursued the best policy, under the circumstances, in leaving the placers open to all; for it would be exceedingly difficult to enforce any regulations not absolntely required by the necessity of the case, and it is more than probable that any attempt at this time to rent out the mineral lands, or to tax their products, would involve a great expense, and it is quite possible that such an attempt would lead to very serious difficulties. Of the large numbers who have been attracted to this country by the flattering prospect of sudden $\pi$ realth, and with the intention of returning to their former homes to enjoy their gains, many foreigners as well as Americans are becoming established in business, and will make California their permanent place of residence. It is therefore well worthy of serious consideration whether the present system may not prove equally beneficial with that of a more exclusive policy. It certainly conduces much. towards doveloping the resources of the country, extending its commerce, and rapidly augmenting its wealth and population. As soon as I have made a personal examination of the gold regions, I shall be prepared to express my views on this subject; but I cannot omit the present occasion to urge upon the government the importance of establishing a mint in California, with the least possible delay. 
Information, not official, has been received, that the revenue laws of the Cnited States have been extended over this country, and that a collector and deputies may soon be expected to take charge of the collection of revenue in this district. On their arrival, all custom-houses and custom-house property will be turned over to them, and the temporary collectors employed by my predecessor and by myself will be discharged. The moneys collected during and since the war, under the direction of the governor of California, and not required for defraying the expenses of the civil government, will be kept as a separate and distinct fund, subject to the disposition of Congress. The grounds upon which this revenue has been collected since the declaration of peace, are fully stated in a letter to the collector of San Francisco, dated the 24th of February last. It may be proper to add, that the course pursued by my predecessor was rendered absolutely necessary by the peculiar circumstances of the case. The wants of the country rendered it imperative upon him to permit the landing of foreign goods in this territory; and had this been done without the collection of duties, large amounts of dutiable goods would have been placed in depot on this coast, to the manifest injury of the revenue and prejudice to our own merchants. The importers have sold their goods at such prices as to corer the duties paid, and still leave them enormous profits; and to now return these duties to the importers would be a virtual gift, without in any way benefitting the people of California. But, to expend this money in objects of public utility in the country, would confer a lasting benefit upon all. I would therefore recommend that such portions of these moneys as may be left, after defraying the 
expenses of the existing civil gorernment, be given to

- California as a "school fund," to be exclusively devoted to purposes of education. No difficulty has been experienced in enforcing the tariff of 1846 , and the revenue has been collected at a very moderate expense, considering the peculiar circumstances of the times.

All officers of the civil government of California will be paid out of the "eivil fund" arising from the customs, the salaries fixed by law, and I would recommend that those officers of the army and navy who have been employed as collectors and receivers of customs in California, both during and since the war, be allowed a fair per centage on the money which they have collected and disbursed. Two and a half per cent. on the amount collected, with the restriction contained in section 2 of the Act of March 3, 1849, is deemed a fair allowance for collecting these customs, and two and a half per cent. on the amount actually expended is deemed ample compensation for keeping and accounting for the same. It rould be more just and proper to make the allowance for the actualexpenditures than for receiving and keeping these moneys; because, if the reversed rule were established, officers who have receired large sums, and within a few days transferred them to others, with no other trouble than merely passing receipts, would be cntitled to a higher pay than those who have had all the trouble of expending this money in small sums, and in keeping and rendering accounts of these expenditures.

As soon as these "civil funds" can be collected from the offeers now holding them, it is proposed to place them in the hands of some officer, or other responsible person, who will act as treasurer for the civil government, with a fixerl compensation for his 
services. On the arrival of the regular collector and deputies, appointed according to law, a full statement will be made of all the moneys which have been collected in California, and the papers and accounts connected with the expenditure of this civil fund will be sent to Washington, as heretofore, in order that all officers who shall receive or expend the same may be held to a strict accountability.

I am, sir, very respectfully, your obedient servant, B. RILEY,

Brevet Brig. Gen. U. S. A., and Governor of California.

Major-General R. Jones,

Adjutant General of the Army, Washington, D. C.

\section{Appendix L.}

Governor Riley took occasion to make an excursion through the gold regions, soon after his affairs with the assemblies were disposed off. A reconnoisance of the valleys of the Sacramento and San Joaquin was made, and particular care given to the matter of establishing military posts for defending the miners and others from the attacks of the Indians. After his return to Monterey, the following despatch was sent to the headquarters of the United States army. The subject of the Indian troubles receives especial consideration.

Headquarters Texth Milttary Departmext, Monterey, California, August 30, 1849.

Colonel: I found, on my return to this place from a reconnoissance of a portion of the ralleys of San Joaquin and Sacramento Rivers, general orders No. 1 
from the headquarters of the army; and, as I cannot have copied in season for transmission by the steamer of the 1st proximo the military correspondengce at these headquarters, I respectfully submit, for the information of the commander-in-chief, a brief summary of reports heretofore made in relation to military affairs in this department.

My attention was directed, on my arrival in this country, to the unparalleled excitement in relation to the mineral regions; the imminent danger that our troops, as they arrived, would desert to the "placers," and, instead of giving protection to the parties, and aid in the preservation of order and tranquillity, would themselves become the very worst element of disorder; the great extent of Indian frontier to be guarded, and the difficulties then apprehended from the unsettled state of affairs in the mining districts. An attentive consideration of these subjects impressed me with the opinion that the policy most likely to prove advantageous to the service, would be the concentration of all the troops serving in this department, except the necessary guards for the depots at one or more points in the immediate vicinity of the gold regions, from whence a portion of them might be permitted to visit the placers for the purpose of working them for their own benefit-the remainder to be held embodied in a proper state of discipline, in readiness for any emergency that might occur. After the expiration of the furlough of the first class, a second class to be furloughed, and so in succession with the remainder; the troops stationed at points so distant from the mines, that they could not be furloughed, to be relieved by exchange with commands that have been more favorably situated. The practice of grant- 
ing furloughs, adopted at some of the posts in this country, with the sanction of the former department commander, had succeedet well, and the information received about the time of my arrival from the southern part of this department confirmed me in the opinion previously entertained, that the mania for goldhunting would exist, in its most exaggerated form, at points most remote from the placers. I accordingly, immediately after relieving Colonel Mason in the command of the department, recommended the adoption of the policy above indicated. It is a matter of regret, that the emergencies of the service have been such that it could not be carried out to the extent recommended; for the experience of the past four months has conrinced me that it is the only course that can be adopted, with reasonable hope of success, until the state of affairs in this country is materially changed. In addition to the mere question of expediency, Indian difficulties that were then occurring, and the threatening danger of a proximate collision betwcen the different classes at work in the gold region, made it highly important that a strong military force should be established in the immediate vicinity of the mining region.

For the disposition of the troops in the department, and the measures taken to prevent desertions, \&c., I respectfully refer to department order and special orders forwarded to you by this mail. These furnish you with a history of the operations in the department since my assumption of the command. The present disposition of the troops is the same as indicated in orders No. 16, except that company A, $2 d$ infantry, re-inforced by details from other companies-in all, four officers and eighty men-has been detached, un- 
der instructions from the commander of the dirision, as an escort for Captain Warner, topographical engineers, and company $\mathrm{E}, 1$ st dragoons, when en route for the station, was diverted from that route, for the purpose of securing the perpetrators of some murders committed by Indians on or near Los Reyes River.

The difficulties apprehended from a collision between the different classes of the mining population have not yet occurred in the form which it was feared they would assume, and at present I do not apprehend any serious difficulty from that source. Some serious Indian disturbances have occurred on the American fork of the Sacramento, and a few isolated murders have occurred at other points; but at the date of the last report from the frontier, every thing was quiet. The Indians of the Sierra Nerada, although in a great number, are of a degraded class, and are divided into so many different tribes, or rancherias, speaking different languages, that any combination on their part is scarcely to be apprehended. Their depredations heretofore have been confined generally to horse-stealing, and only occasionally have murlers been com. mitted by them. These, however, have been made the pretence, by the whites in their neighborhood, for the commission of outrages of the most aggravated character-in one or two cases involving in an indiscriminate massacre the wild Indians of the Sierra and the tame Indians of the ranchos. The commanders of detachments serving on the Indian frontiers are instructed to prevent any authorized interference with the Indians by the whites, and to support the Indian agents of their districts in the exercise of their appropriate duties. From the character of the mining population, and the nature of their occupations, unless 
a strong military force be maintained on that frontier, it will be impossible to prevent the commission of outrages upon the Indians; and they, in turn, will be avenged by murders committed upon isolated parties of whites. Unfortunately, the eagerness with which gold is sought after by detached parties of miners, gives many opportunities for the commission of such outrages. To seek after and apprehend the perpetrators in cases of this kind, a mounted force is absolutely necessary; and, although great difficulty will be experienced in obtaining forage and replacing horses that may be disabled, its scrrices are so inclispensably necessary, that I greatly regret my inability to supply more than one company on the Indian frontier until after the company now on duty with the commissioner of the boundary survey is relieved.

I have heretofore called the attention of the War Department and the division commander to the insufficiency of the force assigned to this department by general order No. 19 of 1818 . As it may not be possible, with the present military establishment, to order any additional force to this country without the action of Congress, I respectfully invite the attention of the commanding general to the views heretofore expressed on this subject. A topographical sketch of a portion of this department is herewith inclosed, upon which I have inticated the positions or neighborhoods in which I deein it important that troops should be established. The amount and character of the foree required in my report to division headquarters, of June 11, is also inclosed.

The embarrassments unler which the service has labored will be so readily appreciated at home, that it is unnecessary to refer to them here except to say 
that, great as these embarrassments have been, they have been greatly increased by the want of line and staff officers.

In consequence of the extraordinary prices of labor, and the consequent enormous expenditures in this country, young officers of the line should not be, in justice to the service and themselves, as they have unnecessarily been, encumbered, in addition to their company duties, with money and property responsibilities to a very great amount. Experienced officers of the quartermaster's department are required at San Francisco, San Diego, and with the commands on the upper Sacramento and San Joaquin Rivers. I have now but one officer, Captain Kane, of that department, under my control; and he is necessarily detained at department headquarters in the preparation of my estimates for the services of the ensuing year. Quarters must soon be erected at several of the posts in this department; and I cannot spare line officers for this duty, without destroying their efficiency with their companies, even were it proper to do so. There are no topographical engineers on duty in this department, and, in consequence of the want, I have been able to perform very little of the duty devolved upon me by the 111th paragraph general orders No. 49, of 1848. A reconnoissance of a portion of the valleys of the Sacramento and San Joaquin Rivers, undertaken for the purpose of determining the position to be occupied, as recommended in my report to division headquarters of April 16, to the War Department of the 25th of the same month, has strengthened my opinion of the importance of giving the country a most thorough examination before any military posts are permanently located in the interior. The whole district of country 


\section{lying between the coast range and the Sierra Nevada} is exceedingly sickly at certain seasons of the year. The common timber of the country (oak) is not fit for building purposes; and I was greatly disappointed in finding that south of the Sacramento River, pine fit for lumber exists only on the spur of the mountains in small quantities, and in places difficult of access. Stone, as a building material is scarce; and at several of the points where it may be desirable to establish military posts, grain for forage is out of the question, and grass can only be found in exceedingly limited quantities. I expressed a hope in my despatches to the War Department of June 30, that I would be able to make an examination of the country along the western slope of the Sierra Nevada, from the source of the San Joaquin to the southern boundary of California; but the season is now so far adranced that I fear I shall not be able to accomplish more than the determination of a position to be occupied in the neighborhood of Los Reyes River. It is of great imimportance that this point should be determined as soon as possible; for the new discoreries of gold constantly being made in that direction, are attracting thither a large portion of the mining population. The rapidly increasing population of the northern placers is gradually forcing the Indians to the south, and congregating them on the waters of the Lake Buena Vista, (Tula.) This position should be occupied, if possible, before the miners have beeome established in Los Reyes and the neighboring rivers; and the necessary examinations and arrangements will be made as soon as it is possible to do so.

Since my application (April 25) for officers of the quartermaster's department was made, two officers of 
that corps, Majors Allen and Fitzgerald, whom I had supposed would be available for duty in this department, have been permanently separated from it; and the number then applied for should be increased by two.

Two of the medical officers in this department are now prostrated by disease; and as their places cannot be supplied here, there should be at least three in this department, in addition to those actually required for duty at the different posts in the department, to meet emergencies of this kind.

The ordnance depots at Monterey and San Francisco are under the charge of military store-keepers. It is important, for the preservation of this property in a serviceable condition, that they should be under the supervision of an experienced ordnance officer.

With the exception of the assistant quartermaster above referred to, the officers above enumerated have heretofore been applied for; but as none have been reported to me, I will state in detail what officers are absolutely required with this command:

Four officers of the quartermaster's department in addition to Captain Kane now on duty here:

Two topographical engineers:

Three additional medical officers:

One officer of the ordnance department:

One officer of the subsistence department.

The irregular communication with some of the interior posts, creates a good deal of embarrassment by delaying the department returns. In consequence of this I am unable to furnish a later return than for June. The transport Mary and Adeline, with companies $\mathrm{A}$ and F, $2 d$ infantry, reached San Francisco on the Sth ultimo. The detachment of dragoons, on 
their march to the department with the collector of this district and the Arkansas emigrants, have not yet arrived. During the months of July and August, so far as reports have been received, there were but few desertions, except from the company detailed for the oscort of Captain Warner, topographical engineers ; thirty-four men, more than half the whole number reported, have deserted from this company. The entire force in the department at this time does not probably exceed six hundred and fifty, (aggregate;) and consequently more than four hundred recruits are now required to fill up these companies to the standard authorized for this department.

A detailed report of my reconnoissance in the valleys of the San Joaquin and Sacramento will be forwarded by the next steamer. I have delayed it in order to embody in it information in regard to the country in the neighborhood of the Tula, which I am in the daily expectation of receiving.

The want of company officers is very much felt; and I request that authority may be giren me to break up the companies whose captains are permanently absent, transferring the officers to other companies, as their services may be needed.

I have the honor to be, very respectfully, colonel, your obedient servant,

\section{B. RILEY,}

Brevet Brigadier-General U. S. Army, commanding. Lieut. Col. W. G. Freeman,

Assistant Adjutant General U. S. Army, Headquarters of the Army, New York. 


\section{Appendix M.}

In the early part of 1848 , Lieut. H. W. Halleck, of the Engineers, was ordered to make a reconnoisance of the coast of Lower California, with reference to the location of works of military defence. In his report to Colonel Mason, after giving a general description of the coast and harbors, and proposing a system of military defence, he submits some remarks upon the commercial and military importance of the peninsula. The whole report is interesting, and furnishes the most correct information upon the subject of the reconnoisance. It will form an interesting conclusion to a work which has been principally devoted to a description and history of Upper California.

\section{LA PAz, Aprit 12, 1848.}

SIR: In compliance with the instructions of the commanding general of the department to make a "reconnoisance of the coast of California, with reference to the location of works of military defence," I reported in my last upon so much as relates to the upper province, and I now submit a few remarks on the military lefence of the peninsula of Lower California.

I. General description of the coast and harbors.The principal ports of the coast of Lower California, visited by whaling and merchant vessels, are San Quintin, MÍagdalena, San Jose, La Paz, Escondido, near Loreto,) and Mulige.- There are some other points which ressels occasionally touch for supplies and at trade, but they are comparatively of little commercial 
or military importance. The port of San Quintin, in latitude thirty degrees twenty-three minutes, is represented as affording a secure anchorage for vessels of every description, and to be sufficiently commodious for the reception of a numerous fleet. The extensive bay of Magdalena has aequired considerable notoriety from its being resorted to every winter by large numbers of whaling vessels. Its size gires it the character of an inland sea, its waters being navigable for the distance of more than a hundred miles. It furnishes several places of safe and commodious anchorage. The bay of San Jose, near Cape Saint Lucas, is much froquented by coasting vessels, and occasionally visited by whalers and men-of-war. Being the outlet of a fertile valley, extending some forty or fifty miles into the interior, it is probably the best place in the peninsula for supplying shipping with water and fresh provisions. It is, howerer, a mere roadstead, affording no protection whatever during the season of southeasters.

La Paz is the seat of govcrnment and the principal port of Lower Califormia, and its extensive bay affords excellent places of anchorage for vessels of any size, and is sufliciently commodious for the most numerous fleets. The principal pearl fisheries are in this immediate vicinity, and also the most valuable mining districts. It is the outlet of the fertile valley of the Todus Santos, and of the produce of the whole country between Santiago and Loreto. The core or estero, opposite the town of $\mathrm{La} \mathrm{Paz}$, furnishes spacious and safe anchorage, which may be reached by ressels drawing not more than eightcen or twenty feet of water; and the core of Pichilingue, at the south-eastern extremity of the bay, and about 
six miles from the town, affords an excellent anchorage for vessels of any size; but the inner bay can be reached only by small merchant vessels. The bar, however, between the two is only a few yards in extent; and if the importance of the place should ever justify it, the channel might be made deeper without difficulty or great expense. The adjacent country being barren and mountainous, and the roads to the interior exceedingly difficult, this place can never be the outlet of much agricultural produce. But as the island of Carmen, nearly opposite the entrance to this bay, contains an almost inexhaustible supply of salt, very easy of access, it is possible that the trade in this article may eventually give considerable importance to the port of Escondido.

The bay of Mulige contains several places of anchorage, but none of them are deemed safe for large vessels, $0:$ even from small ressels, at all seasons of the year. There are also several other parts in the gulf farther north which are occasionally visited by coasting vessels, but it is not known that any of them are likely to be of much commercial importance.

II. Proposed system of defence.-It is not supposed that, under existing circumstances, any military post will be necessary on the western coast of the peninsula; nor is it probable that, for many years, any place there will become of sufficient importance to justify the construction of military works for its defence. It is true that the whale fishery on this coast has become, from the amount of shipping engaged in it, an object of the highest consideration; but our having ports of refuge at San Francisco or San Diego, and at La Paz, strong enough to resist a naval coup de main, will, it is believed, afford sufficient 
security to these whalers in case of a war with \& maritime power.

On our arrival here in October last, it was deemed desirable to establish a small military post at San Jose, for the double purpose of giving protection to the friendly inhabitants against a band of Mexican freebooters who had crossed the gulf from Guaynas to Mulige and Loreto, and of preventing the further introduction of men and munitions from the opposite coast. The old mission building was found well adapted to the purpose in view, and with a few repairs and improrements served as an admirable protection for the little garrison in the several attacks which it afterwards sustained from greatly superior forces. It will probably be necessary to continue this post during the war with Mexico, or at least so long as there is any danger of the enemy's sending troops from tho opposite coast to again disturb the trariquillity of the peninsula; but it is not decmed advisable to establish at this place any works of permanent defence, the character of the port not being such as to warrant expenditures for this purpose. The defences of the cuartel or mission building are decmed sufficient for all purposes of temporary occupation.

Should the war with Mexico continue, and the naral forces be again withdrawn from the gulf, it may be necessary to establish temporarily a small military post at Mulige; but no permanent garrison will bo required either at that place or Escondido, unless, perhaps, hereafter the commercial importance of the latter port should justify such a measure.

La $\mathrm{Paz}$ is, therefore, the only port in Lower California which it will be necessary, for the present, to occupy with a permanent military force, or to secure 
by means of fortifications. For temporary purposes, the site of the old cuartel is well suited for the construction of defensive barracks, inasmuch as it commands the town, and may readily be secured against an attack from the side. The buildings at present occupied as barracks are not judiciously located. A permanent work on Punta Colorada will completely close the entrance to Pichilingue cove, and its heary guns will reach the entrance to the channel of $\mathrm{La} \mathrm{Paz}$; but to give the requisite security to the latter, a small battcry will be necessary on Punta Prieta. The topographical features of both these points are favorable for the construction of small fortifications. Stone of good quality for building purposes is found in the immediate vicinity, and good lime may be procured at the distance of only a few miles. Quarries have been opened in the "Calaveras," and the stone, though soft and casily worked, is found to be in this climate of a very durable character. $\mathrm{L}_{\mathrm{a}} \mathrm{Paz}$ is not difficult to defend against a naval attack, and the proposed fortifications may be constructed in a short time and without a very large expenditure of money. The commercial character of the place, its military importance as connected with the defence of the peninsula, its great value as a naval depôt and port of refuge for our commercial and military marine in case of war with any naval power, will, it is believed, fully justify the expenilitures necessary for securing this port against a maritime attack.

III. Commercial and mititary importance of Lower California.-Thus far in my report I have procecded on the supposition that it is the intention of our government to retain the whole of California in any 
treaty of peace with Mexico; but doubts have recently been expressed on the policy of retaining this peninsula, on account of its being of little or no value to the United States. As the guerrilla forces which were sent over from Mexico the past summer, during the absence of our squadron from this coast, to regain possession of Lower California, and force the inhabitants to their allegiance to the Mexican gorernment, have been defeated and completely dispersed, leaving our own troops in undisputed possession of the territory, nothing but a conviction of the utter worthlessness of the country could now induce our government to consent to its abandonment. On this subject I beg leave to add a few remarks:

The peninsula of California lies between twentytwo degrees fifty minutes and thirty-two degrees thirty minutes north latitude, being about seven hundred miles in length, and varying from fifty to one hundred miles in breadth. An irregular chain or broken ridge of mountains extend from Cape St. Lucas to the frontiers of Upper California, with spurs running off on each side to the gulf and ocean. Between these spurs are numerous broad plains covered with stunted trees, and during the rainy months with a thin but nutricious grass. In the dry season this grass is parched up like hay, but from its nutricious character it affords abundant food for the herds of cattle and horses which constitute the principal wealth of rancheros. The dryness of the soil prevent the growth of trees of any considerable magnitude, except on the borders of a few mountain streams. This timber, though far from being plentiful, is exceedingly durable and much esteemed in ship-building. The greatest height of the mountains is estimated five thousand feet; many of 34 
them are piles of mere broken rocks, while others are covered with grass, shrubbery, and small trees. The plains are sandy and mostly unproductive-not, however, from any natural barrenness in the soil, but from a deficiency of water. There are but few durable streams in the whole country, and streams of good water are extremely scarce. But in the plains and most of the dry beds of rivers water can be obtained by digging wells only a few feet in depth; and wherever irrigation has been resorted to by means of these wells, the produce of the soil, from its remarkable fertility, has abundantly rewarded the labor of the agriculturist. Much of this soil is of volcanic origin, having been washed from the mountains by the action of heavy rains, and the produce extracted by means of irrigation from these apparently barren and unprolific sands is something most marvellous. The general aspect of the country on the coast is exceedingly barren and forbidding, but I have seen no instance where the soil is properly cultivated that the labor bestowed on it is not well rewarded. The growth of vegetation is exceedingly rapid, and the soil and climate are such as to produce nearly all the tropical fruits in great perfection. But the inhabitants are disinclined to agriculture, and most of them live indolent and roving lives, subsisting principally upon their herds. Notwithstanding the unfavorable character of the country, it is capable, in the hands of an industrious and agricultural people, of supporting a population much more numerous than the present. In the time of the missions, when very small portions of the soil were cultivated, and even these but rudely, by the Indians, the four districts of San Jose, Santiago, San Antonio, and Todos Santos con- 
tained a population of thirty-five thousand souls, whereas, the present population of the same districts is only seven thousand.

The agricultural products of Lower California are maize, sugar-cane, potatoes, dates, figs, grapes, quinces, lemons, and olives. A considerable quantity of hides, beef, cheese, soap, sugar, figs, raisins, \&c., is annually exported to Mexico and Upper California, flour and merchandise being received in exchange. The vegetable market of Mazatlan is also in part supplied from the valley of San José.

But the value of Lower California does not result from its being either a grazing or agricultural country. Its fisheries, mines, commerce, and the influence of its geograplical position, are matters of much higher importanse than its agricultural productions.

The whole coast of the peninsula abounds with fish; clams and oysters are found in great plenty and of every variety. The islands of the gulf abound with seal, and the whaling grounds on the Pacific coast are of great value. During the past year Magdalena bay alone has, at one time, contained as many as twenty-eight sail, all engaged in this fishery. The pearl fishery is also exceedingly valuable. Formerly, when it was conducted with system and regularity, the annual produce of a single vessel with thirty or forty divers, between the months of July and October, usually amounted to about $\$ 60,000$; and now, badly as the fishery is conducted, the annual exportation of pearls amounts to between forty and fifty thousand dollars. Tortoise and pearl shells are also articles of exportation.

Lower California contains valuable mines of gold, silver, copper, and lead; but, for the want of capital, 
very few of these are worked, and this in the rudest manner possible. Nevertheless, the labor expended on them is well rewarded; and there can be no doubt that with capital and suitable means they would yield very handsome profits. The salt mines on Carmen island are capable of supplying the whole coast of Mexico and California; already the duties on this article amount to a considerable sum.

The commerce of the peninsula is now very limited, being principally confined to a coasting trade with the ports of Mexico. The whole population of the country is but little more than ten thousand, and the annual imports and exports are estimated at $\$ 300,000$. But in our hands this commerce, freed from the absurd restrictions imposed by Mexico, will soon receive a very great extension. La $\mathrm{Paz}$ will become the principal depot of American goods for the western coast of Mexico; and in a few years most foreign goods intended for this coast will also be deposited in the warehouses of Lower California, to be transferred to the ports of Mexico at such times and in such quantities as the demands of the market may require. In the present variable state of Mexican trade, resulting from an irregular and fluctuating tariff, which differs for each port and changes with every change of general or state administration, it is frequently necessary to transfer vessels with their cargoes from one port to another, or to keep them for weeks at sea, standing off and on, so as to enable the agents to arrange the rate of duties at the custom-house before landing the cargoes. Sometimes the consignees are obliged to send their vessels to the Sandwich islands or Valparaiso until a change of administration will enable them to avoid the exorbitant demands of some 
petty governor or collector of customs. Moreover, the principal commercial ports of this coast (Mazatlan and San Blas) are inaccessible to merchant vessels for four months of each year, and during that time are visited only by small coasters. But, with Lower California in our possession, merchant vessels of whatever character, at all seasons and in all winds, can find a refuge in $\mathrm{L}_{a} \mathrm{Paz}$, and their cargoes despatched in such quantities and to such points of the opposite coast as circumstances may justify. This place in a few years will be what Mazatlan now is, and Mazatlan experience the fate of San Blas and Acapulco.

The importance, however, of this port results mainly from its geographical position, and the influence it is likely to exert as a military and naval depot upon our commercial interests in the Pacific. The port of San Francisco, in Upper California, should be well fortified, and every care taken to make it a harbor of refuge for our merchant and military marine, in case of a maritime war; but it must be remembered that that place is nearly fifteen hundred miles from the nearest port of Mexico, and that it is very far north of some of the best whaling grounds in the Pacific, and too distant to afford much protection to our commerce with Central America, although its position gives it a controlling influence over the commerce of Sandwich Islands, Upper California, and Oregon. In the same way a well-fortified naval station at La Paz, from its immediate proximity to the coast of Mexico, would have a most beneficial influence on our commercial and whaling interest in this part of the Pacific. The great value, in time of maritime war, of such key points as $\mathrm{La} \mathrm{Paz}$, and the commanding 
influence exercised by them in the protection of commerce, have become settled principles in military defence; and England shows her appreciation of their truth, and the wisdom of her own policy, in establishing stations and points like St. Helena, Cape of Good Hope, Gibraltar, Malta, Corfu, and Bermuda.

Again, the growing commerce of California and Oregon, and the political importance of our possessions on the Pacific, render it necessary that we should have some means of rapid communication between them and the seat of government at Washington. This communication must be effected by the isthmus of Panama or of Tehuantepec. In either case steamers bound to Upper California and the Columbia River must have one or more intermediate depots of fuel; and in time of war it is important that these depots be established in our own rather than in a hostile territory. A glance at the map will show that $\mathrm{La} \mathrm{Paz}$ is nearly equidistant from the extremities of this line; and that Tehuantepec, La Paz, and San Francisco divide into four equal parts the whole distance from Panama to Oregon. Moreover, as this ocean is peculiarly suited to steam navigation, a large part of the commerce of the Pacific must eventually be carried on in steam vessels; and in all probability not many years will elapse before a portion of our naval force in these waters is of the same character. Under this supposition, the importance of our possessing some naval depot and harbor of refuge and repair south of Upper California is too manifest to require argument or illustration.

But whatever may be thought of the value of this peninsula or of the gulf as a natural boundary between us and Mexico, instead of an imaginary line drawn 


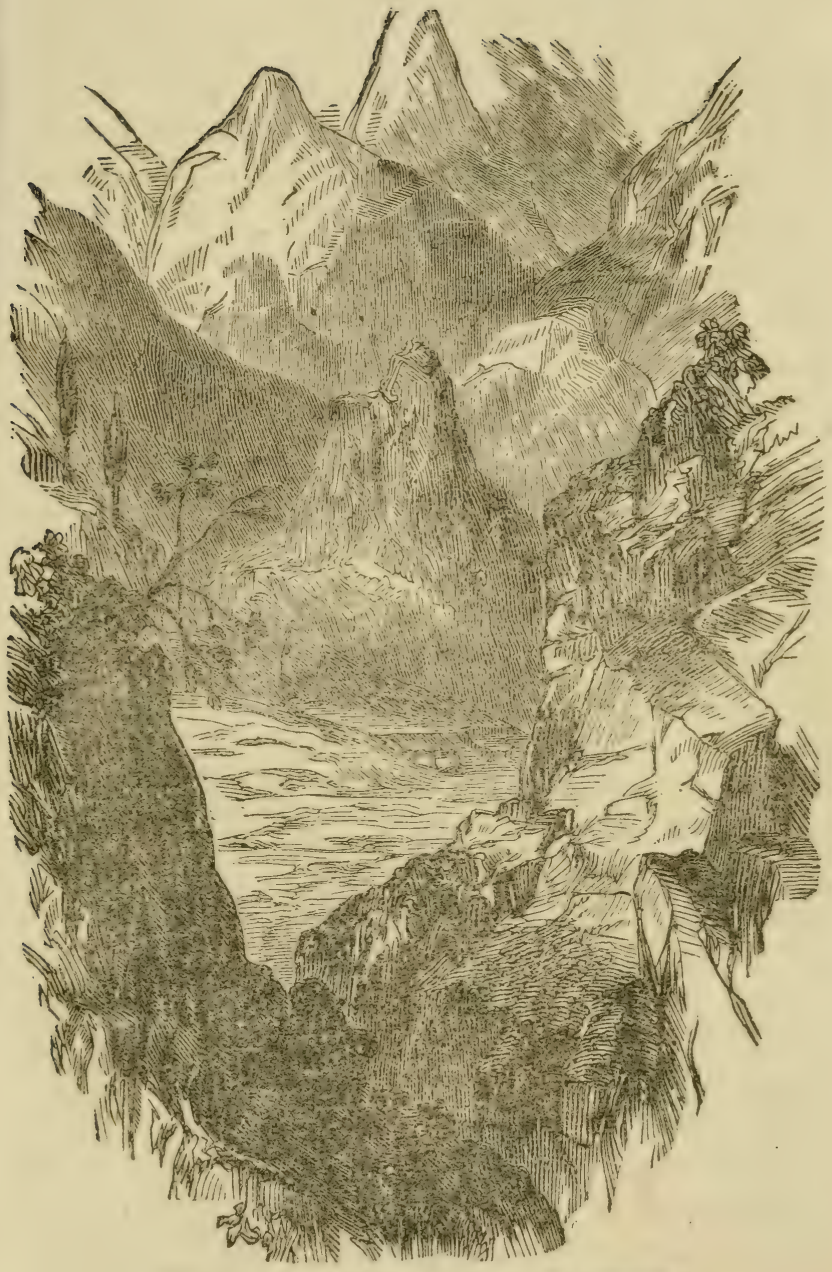

MOONTAIN SCENERY-LOWER CALIFORNTA 

from the Colorado to the Pacific, thus separating a kindred people, and exposing the governments of the two territories to continual collisions, the propriety of retaining Lower California is, in my opinion, now no longer an open question. When this country was first taken possession of by the forces of the United States, the people were promised the protection of our government against Mexico, and guarantied the rights secured by our Constitution; and in Norember, 1817, they were assured by the commander-in-chicf of the Pacific squadron, (with the approbation of the Secretary of the Navy,) that this territory would be permanent7y retained by the American government; and again, by the President of the United States, in his annual message of December, 1847, that it "should nerer be given up to Mexico." Acting under these assurances, all the most respectable people of the territory not only refused to take part with the Mexican forces which were sent to attempt the recapture of that country from the Americans, but many of them actually took up arms in our defence, and rendered most raluable scrvices in ridding the peninsula of the guerrilla hordes sent over from Mexico for the purpose of effecting vur expulsion. In this conflict, some who thus sided with us lost their lives, many their property, and all have exposed themsclves to the rengeance of the Mexican gorernment. But these losses and dangers they have willingly encountered, in the hope of obtaining the better government of the United States. They have regarded these promises as made in good faith, and have boen guided in their conduct by the assurances thus held out to them by the agents of the American government; and now, for the United States to voluntarily surrender this country to the 
republic of Mexico, and leave these Californians exposed to the loss of life and confiscation of property, for having sided with us, under the assurances thus held out to them, would not only be in itself a breach of national faith, but would make us appear in the eyes of the world guilty of the most deliberate and cruel deception.

\section{H. WAGER HALLECK.}

Lieutenant of Engineers.

Colonel R. B. Mason,

Commanding Tenth Military Department. 





LIBRARY OF CONGRESS

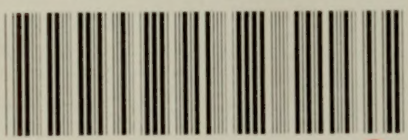

0017167346 A 